
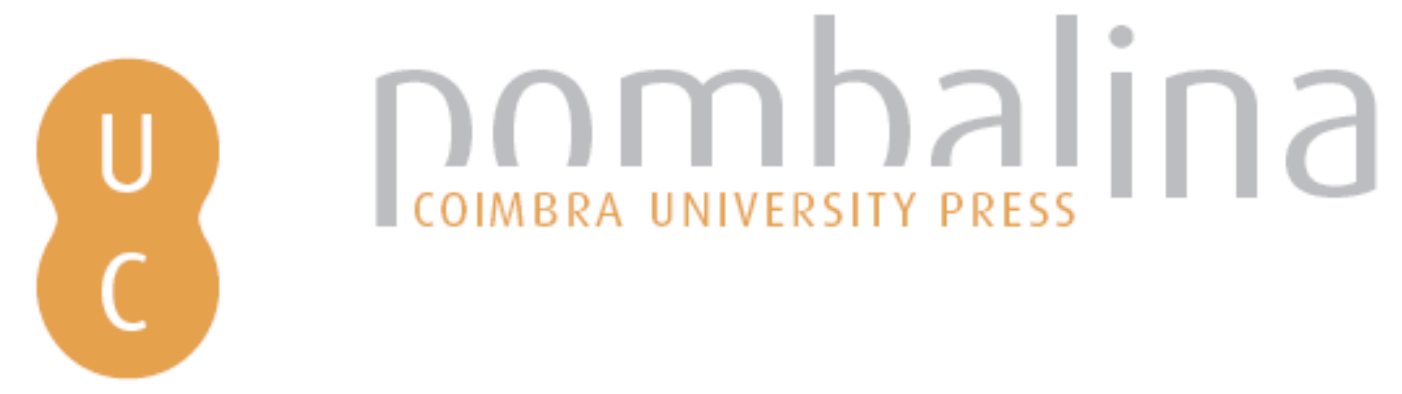

\title{
Desenho: plasticidade e prática conceptual
}

Autor(es): $\quad$ Olaio, António; Pousada, Pedro

Publicado por: Imprensa da Universidade de Coimbra

URL

persistente: URI:http://hdl.handle.net/10316.2/31857

DOI: $\quad$ DOI:http://dx.doi.org/10.14195/978-989-26-0746-7

Accessed : $\quad$ 19-May-2017 17:33:40

A navegação consulta e descarregamento dos títulos inseridos nas Bibliotecas Digitais UC Digitalis, UC Pombalina e UC Impactum, pressupõem a aceitação plena e sem reservas dos Termos e Condições de Uso destas Bibliotecas Digitais, disponíveis em https://digitalis.uc.pt/pt-pt/termos.

Conforme exposto nos referidos Termos e Condições de Uso, o descarregamento de títulos de acesso restrito requer uma licença válida de autorização devendo o utilizador aceder ao(s) documento(s) a partir de um endereço de IP da instituição detentora da supramencionada licença.

Ao utilizador é apenas permitido o descarregamento para uso pessoal, pelo que o emprego do(s) título(s) descarregado(s) para outro fim, designadamente comercial, carece de autorização do respetivo autor ou editor da obra.

Na medida em que todas as obras da UC Digitalis se encontram protegidas pelo Código do Direito de Autor e Direitos Conexos e demais legislação aplicável, toda a cópia, parcial ou total, deste documento, nos casos em que é legalmente admitida, deverá conter ou fazer-se acompanhar por este aviso.

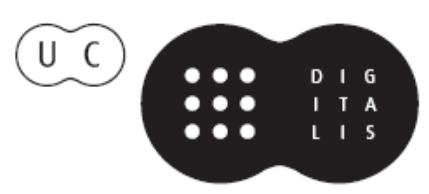


ANTÓNIO

OLAIO

PEDRO

POUSADA
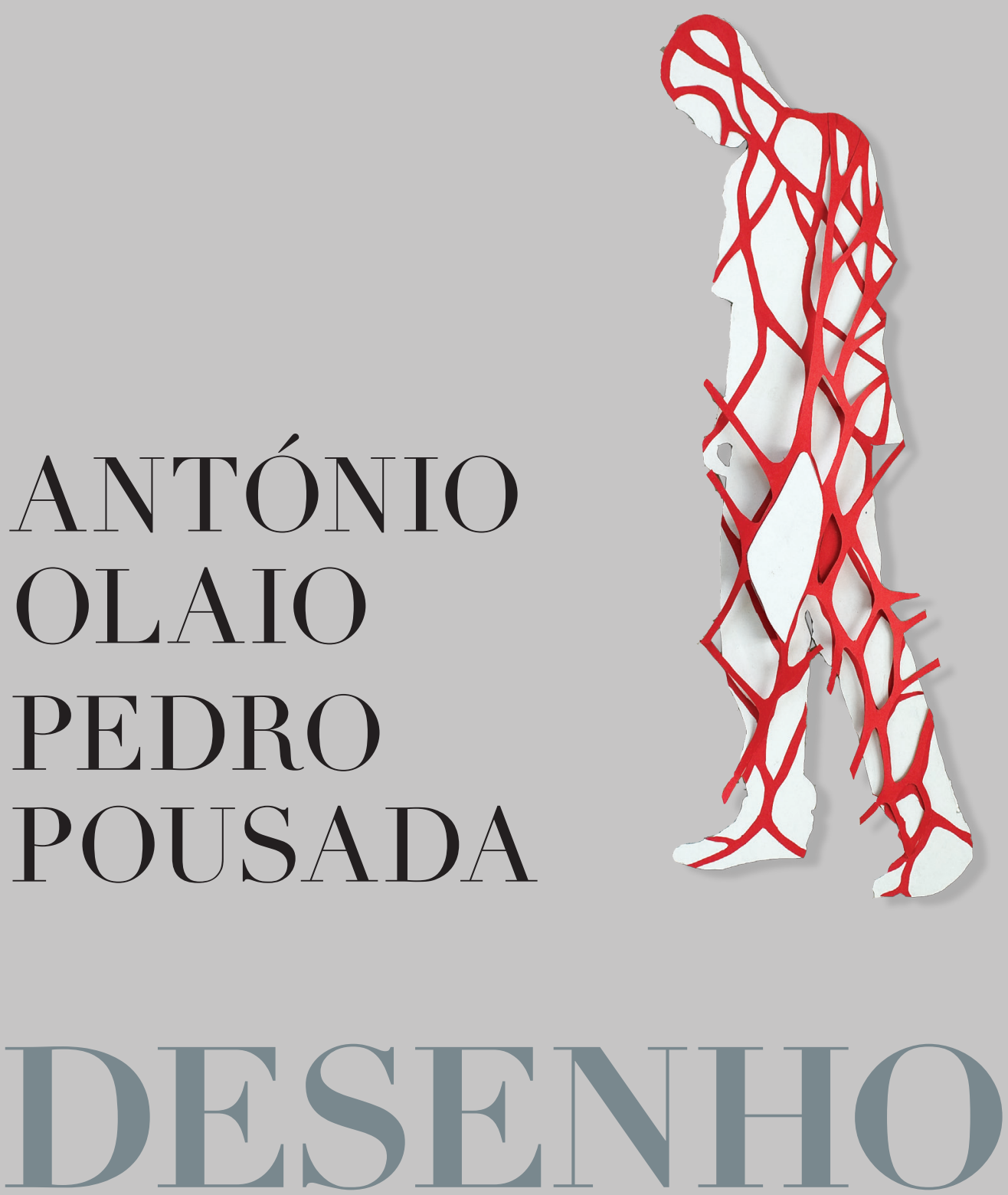

plasticidade e prática conceptual 
(Página deixada propositadamente em branco) 

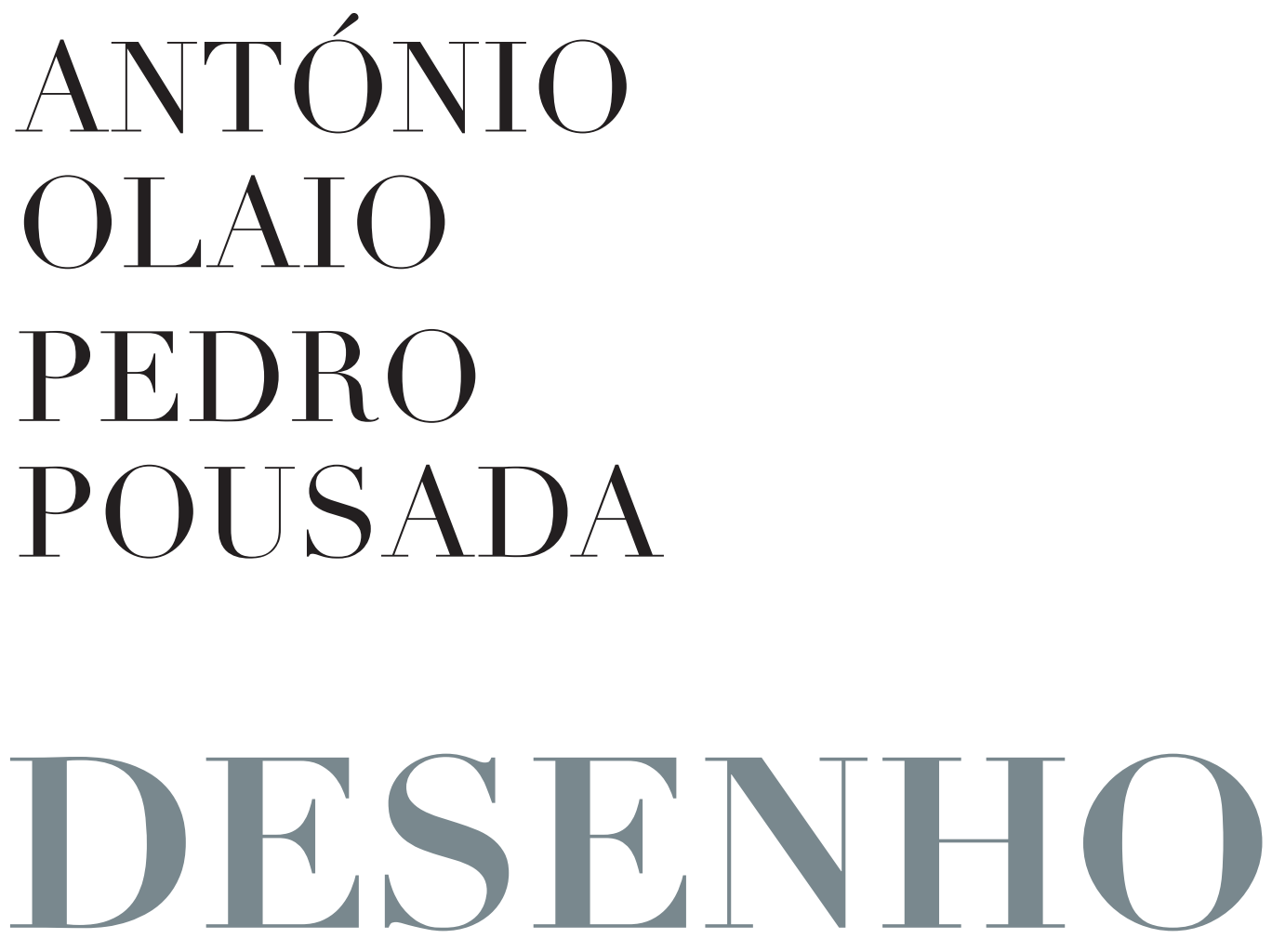

plasticidade e prática conceptual 


\author{
EDIÇÃO \\ Imprensa da Universidade de Coimbra \\ URL: http://www.uc.pt/imprensa_uc \\ Email:imprensa@uc.pt \\ Vendas online: http://livrariadaimprensa.uc.pt \\ PRÉ-IMPRESSÁO \\ Carlos Costa \\ IMPRESSĀO E ACABAMENTO \\ Tipografia Lousanense \\ ISBN \\ 978-989-26-0745-0 \\ ISBN DIGITAL \\ 978-989-26-0746-7 \\ DOI \\ http://dx.doi.org/10.14195/978-989-26-0746-7 \\ DEPÓSITO LEGAL \\ $375255 / 14$
}

(C) MAIO 2014, IMPRENSA DA UNIVERSIDADE DE COIMBRA 


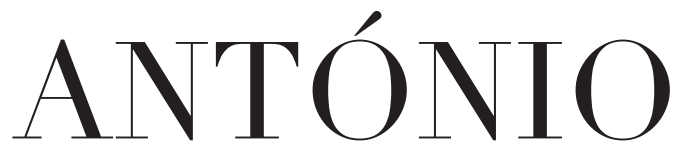

OLAIO

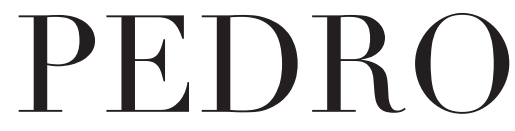

POUSADA
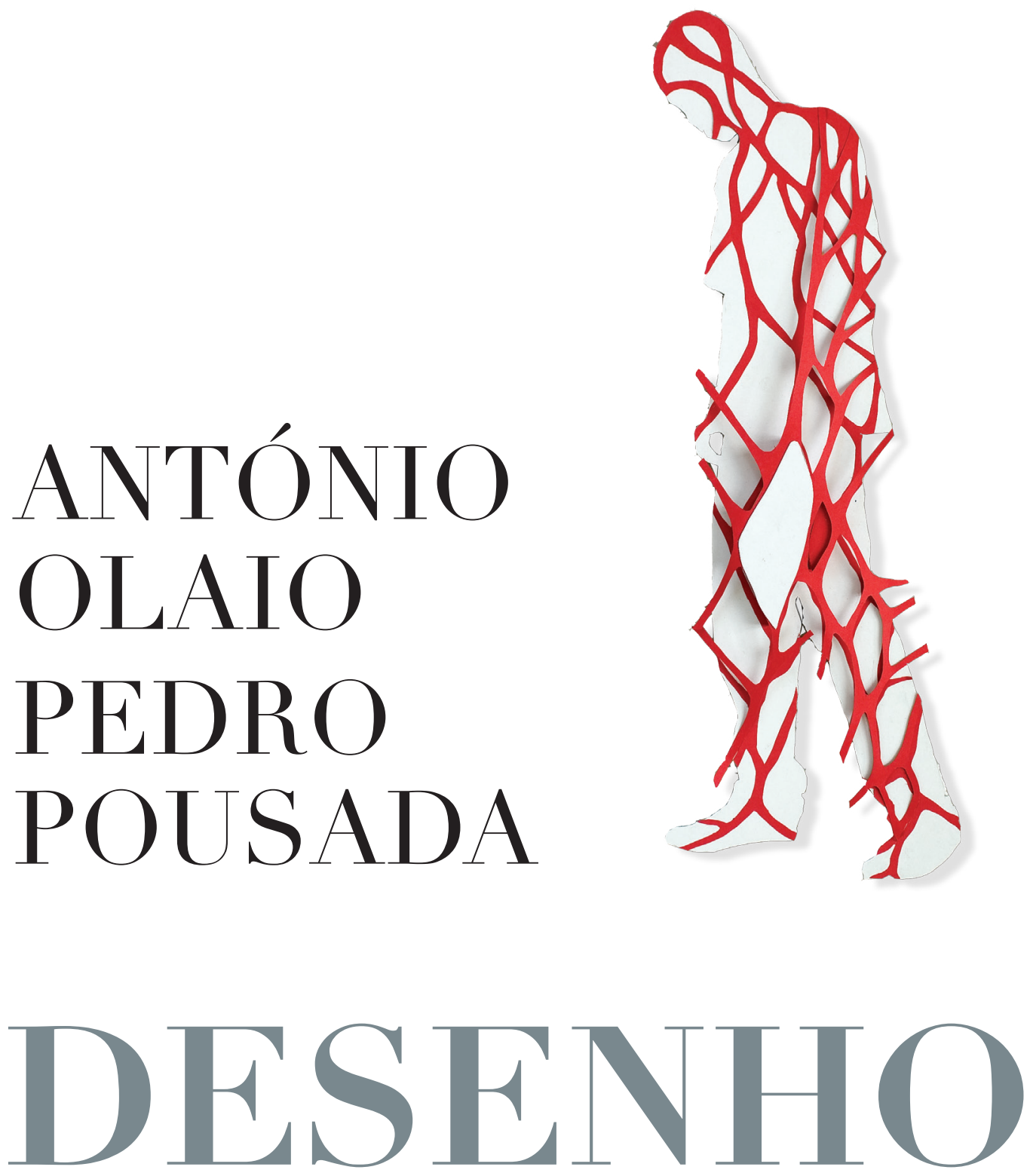

plasticidade e prática conceptual 
(Página deixada propositadamente em branco) 


\section{SUMÁRIO}

PRÁTICA CONCEPTUAL...........................................................................

O DESENHO COMO INSCRIÇÃO E INVENÇÃO ...................................11

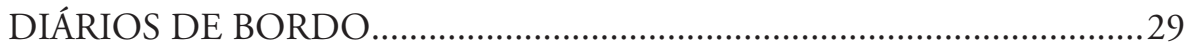

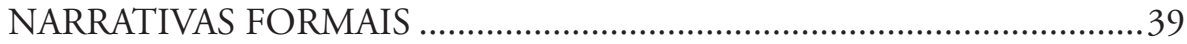

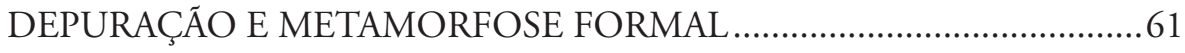

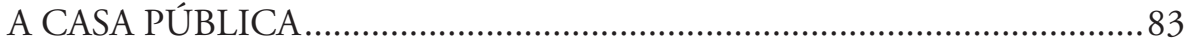

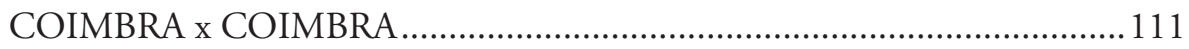

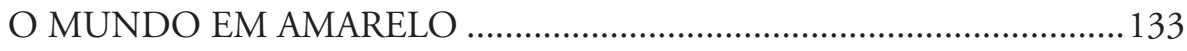

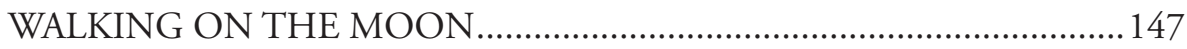

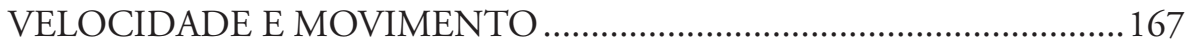

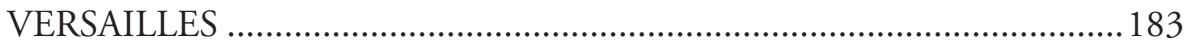

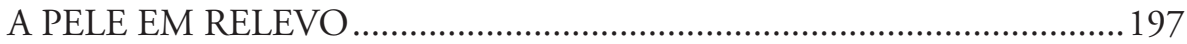

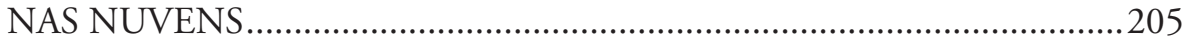


(Página deixada propositadamente em branco) 


\section{PRÁTICA CONCEPTUAL}

Mais de 7 anos passados da edição de "Desenho, percepção e investigação formal" e perante a possibilidade de uma reedição, preferimos fazer agora um novo livro.

Continuam a ser a matéria-prima deste livro exercícios realizados na disciplina de Desenho II do curso de arquitectura (Departamento de Arquitectura da Faculdade de Ciências e Tecnologia da Universidade de Coimbra), mas agora com uma presença reforçada de trabalhos onde os desenhos participam no seu processo conceptivo embora náo estando explícitos no seu resultado final.

Embora com muitos pontos em comum com o livro de 2006, este livro agora apresentado reserva um espaço menor aos aspectos perceptivos do desenho, o que não reflecte a importância que lhes damos nas nossas aulas. Se este a intenção deste livro fosse documentar a nossa prática pedagógica, os exercícios de representação teriam certamente aqui um espaço muito superior. Por outro lado, entendermos que o público deste livro vai bem para além do curso em que estes trabalhos foram realizados e, mesmo, da sua própria área disciplinar.

Em "Desenho, percepção e investigação formal" o corpo dos trabalhos realizados levou-nos a uma abordagem que explorava as complexidades dos processos de percepcionar o mundo através do desenho, nas potencialidades de diferentes escolhas e opçóes gráficas e, por outro lado, à exploração do desenho como espaço de exploração formal, lugar onde se geram outras formas, onde as formas dão lugar a outras formas.

É esse espaço de criação formal (na relação entre o campo de possibilidades do devir das formas e a procura de nexo conceptual) que é dominante agora nos trabalhos apresentados neste novo livro. O sentido da palavra conceptual manifesta-se aqui enquanto lugar das ideias no processo criativo e no sentido comunicacional dos seus produtos, mas também, e sobretudo, no seu sentido processual, destes trabalhos como resultado do desenho enquanto processo conceptivo. 
Contrariando o hábito (sobretudo presente em muitas abordagens às práticas artísticas contemporâneas) de associar a palavra conceptual à ausência ou, pelo menos, à minimização do esforço, sobretudo o manual, a expressão "prática conceptual" no título deste livro tem o sentido de enfrentar a dimensáo mental dos processos conceptivos sem qualquer descontinuidade com a manualidade, encarando-as como práticas da mesma natureza. E, na complexidade da mente humana, a plasticidade é, desde logo, a sua principal qualidade, assumindo potencialidades renovadas quando se afirma na visualidade.

António Olaio 

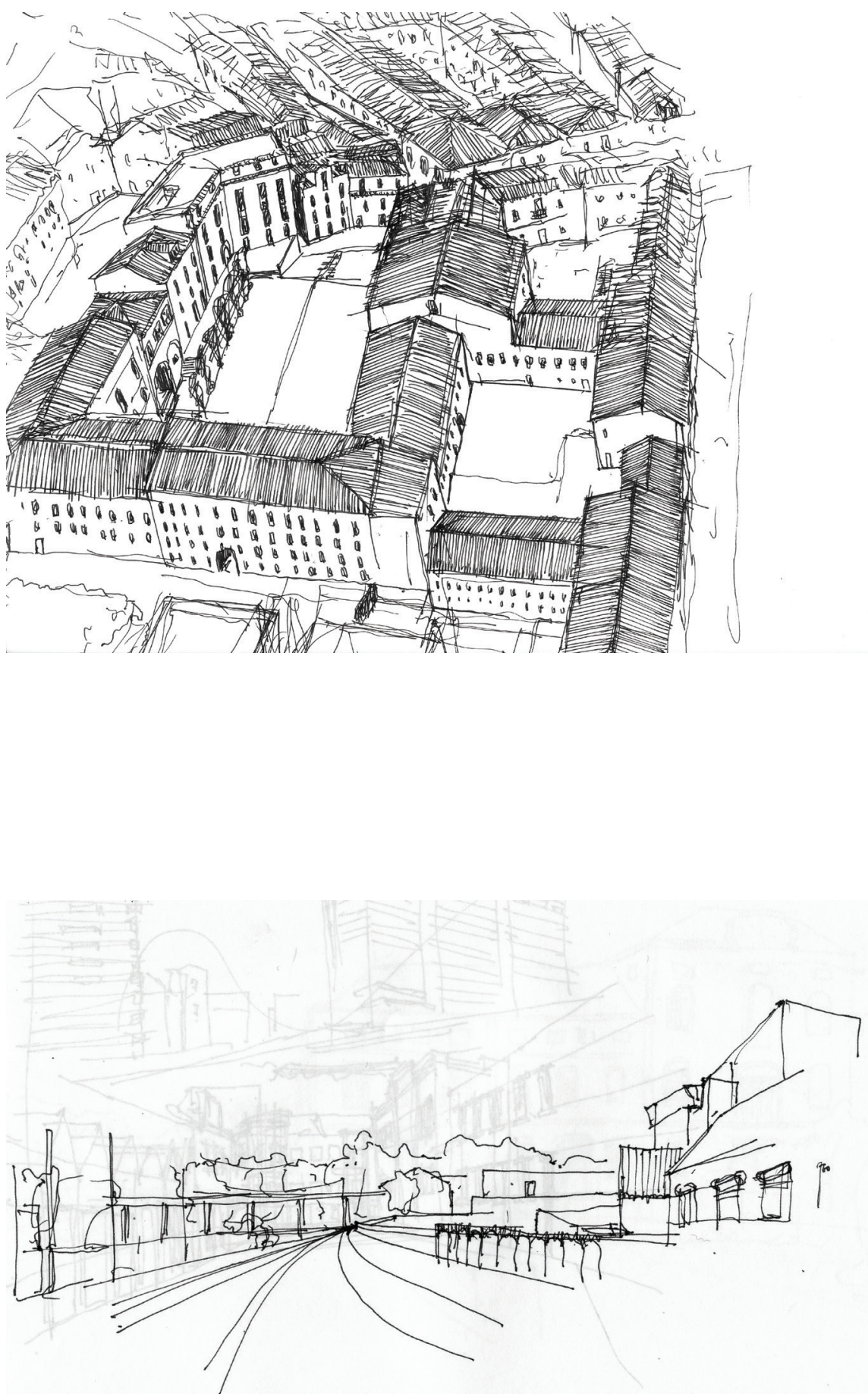

André Almeida, Helder Ferreira 
(Página deixada propositadamente em branco) 


\section{O DESENHO COMO \\ INSCRIÇÃO E INVENÇÃO}

Testemunhos classificados de objectos de reacção poética e que pelas suas formas, pelas suas dimensóes, pelos seus materiais, pelas suas possibilidades de conservaçáo são capazes de ocupar o nosso espaço doméstico, tais como seixos polidos pelo oceano ou como um fragmento de um tijolo, arredondado pelas águas de um lago, ou de um rio; ossadas, fósseis, raizes de árvores, algas por vezes quase petrificadas e conchas lisas como porcelana, esculpidas à grega ou à hindu. Búzios revelando-nos as suas extraordinárias esculturas helicoidais [...] é através destes objectos que existe um contacto amigável entre nós e a natureza.

E foi assim que num determinado momento tomei-as como temas dos meus quadros e das minhas pinturas murais. Estes objectos não ornamentam o meu apartamento ou a minha casa. Eles ocupam-nas. Eles ocupam sobretudo o meu espirito. Existem por todo o lado [...] debaixo dos nossos pés, onde quer que seja [...], o principal é conseguir vê-los, observá-los, reconhecê-los e compreender que são admiráveis porque de um modo geral eles exprimem e contém as leis da natureza. Há largos anos que a minha admiração e encantamento tem aumentado e a meditação associada a esse prazer tornou-se inquietante. Angustiada pelo porquê, pelo como. O como: necessidade do homem. O porquê: sem resposta.

Le Corbusier in Menz, Casar \& Jornod, Naima (Eds.), Le Corbusier ou la synthèse des arts, Milano: Skira, 2006.p.97-98. 

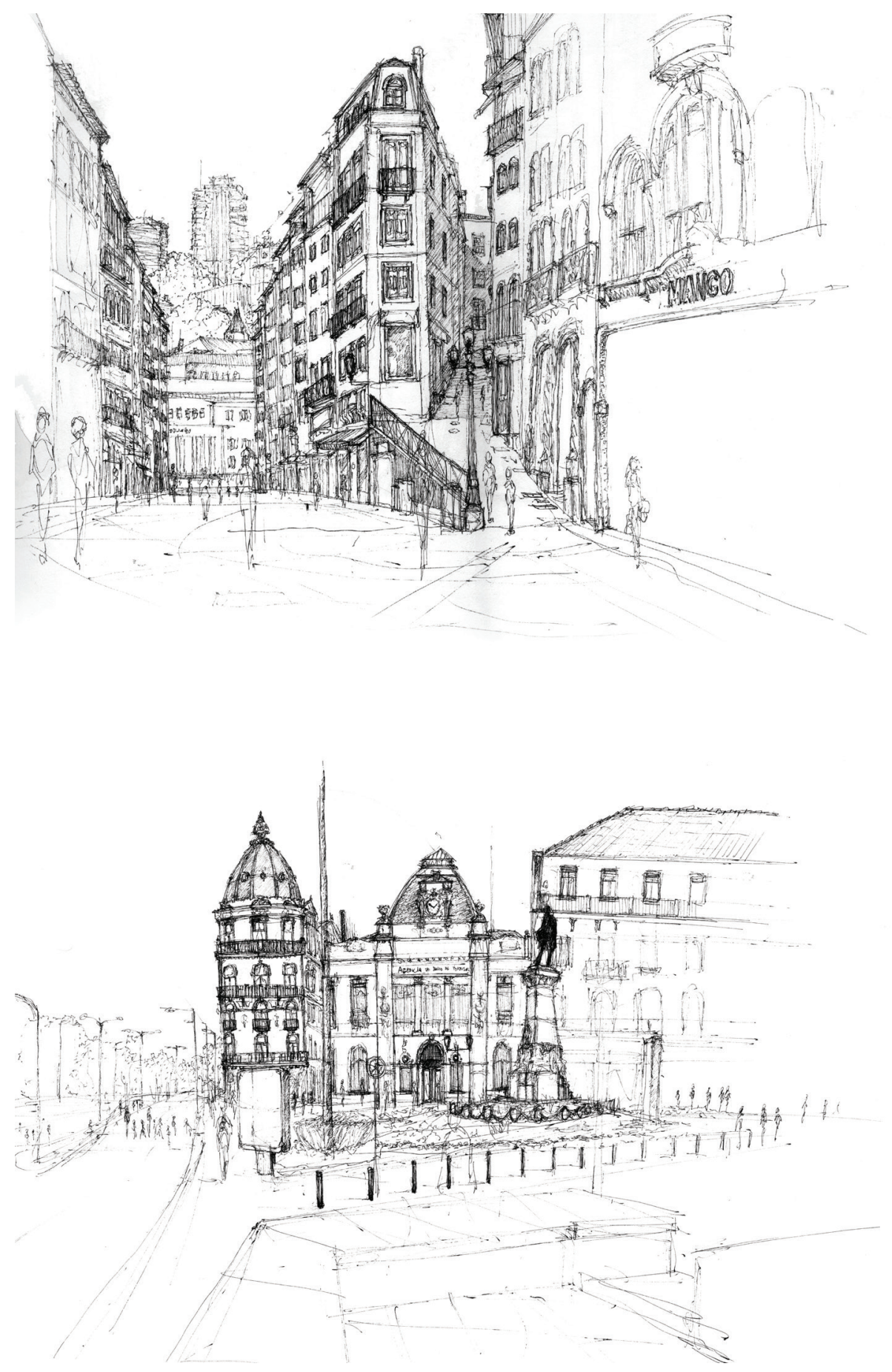

Rui Agnelo 
Os trabalhos desenvolvidos na disciplina de Desenho II do Departamento de Arquitectura da FCTUC propõem uma relação produtiva e de continuidade entre a percepção e imitação do observado e a invenção plástica.

Tem sido uma das intençóes programáticas desta disciplina reverter para o campo da criação projectual específica do ensino da arquitectura, a complexidade poética que define na contemporaneidade a extensão e os processos de desenhar e de conceptualizar o desenho. Com esta estratégia consolida-se, pensamos nós, a condição de anomia do acto de desenhar, isto é, supera-se a ideia do desenho como instrumento. $\mathrm{O}$ desenho já náo prova o seu valor apenas na acção utilitária e prescritiva (na socialização de um dever-ser do desenho: legível, operante, clarividente mas muito pouco auto-crítico) mas nas funçóes imprevistas, desconhecidas para os seus autores que a posteridade pode atribuir à sua aparente arbitrariedade e ao seu carácter incompreensível.

Procura-se com este método transformar o modo como o aluno pensa as imagens e a sua função no mundo em que vivemos, como intui graficamente as ideias, e sobretudo como aprende a compreender o problema não pelo imperativo de alcançar uma resposta mas pelo facto de a sua indefinição nos proporcionar um entendimento mais duradouro sobre as outras dimensóes desse objecto em constante renovação "no contexto daquilo que sempre existiu" que é a arquitectura. Todo o repertório da pedagogia e experiência artística moderna e do encantamento por tudo o que ainda não está dominado no mundo reaparece nestes exercícios.

A tradutora russa Rita Rait-Kovaleva ${ }^{1}$ conta que numa das exposiçóes OBMOKHU do grupo construtivista, ela e um grupo de amigos penduraram por brincadeira os seus casacos nas construçóes espaciais ai expostas; Mayakowsky, indignado, explicou-lhes que aquelas estruturas não eram cabides mas obras que indicavam novas relaçóes entre as formas, contrariavam a ideia de volume e incluíam o vazio e a dissoluçáo do exterior e do interior dessas superfícies como características plásticas, expondo os materiais a condições nunca dantes experimentadas, em suma, antecipavam um novo entendimento da tecnologia e da estética; mais tarde compreendeu melhor as palavras do poeta soviético quando ao traduzir o texto de Gertrude Stein sobre Picasso encontrou uma parte que se referia ao período da Grande Guerra; contava Stein que em Paris no Boulevard Raspail, Picasso e ela se depararam com um combóio de canhóes pintados com padrôes camuflados; diante dessas pinturas

\footnotetext{
${ }^{1}$ Maria Gough, In the Laboratory of Constructivism: Karl Ioganson's Cold Structures, October, Vol. 84. (Spring, 1998), pp. 91-92.
} 


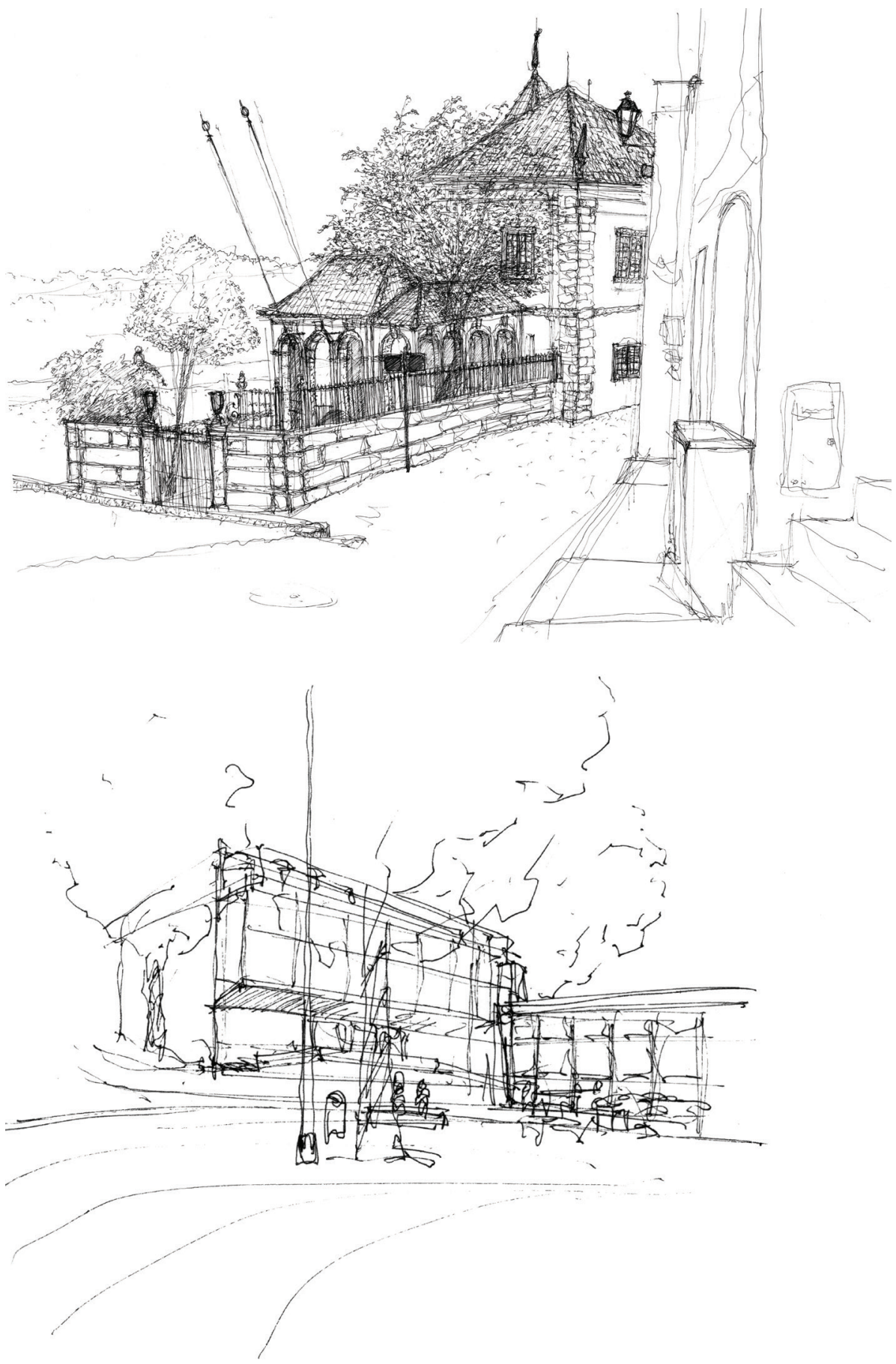

Rui Agnelo 
Picasso reagiu afirmando: “(...) nós é que fizemos aquilo! Aquilo é Cubismo". Karl Ioganson, construtivista russo e participante da referida exposição afirmaria em Maio de 1921 que "os inventores do rádio não sabiam muito bem o que iam fazer com aquilo. ${ }^{\text {” }}$

É neste plano que nos situamos, estas formas, este método de trabalho expressam a capacidade de se utilizarem técnicas de inscriçâo, recorte, colagem e montagem para erguer um entendimento mais abrangente da ideia de organização, de objectivo, de analogia, de construção; entendimento esse que pode proporcionar mais imprevisibilidade ao quotidiano de investigaçáo, experimentação e análise do design studio e sobretudo resgatá-lo da tecnocracia e da sua tendência para "identificar a existência com o puro interesse da acção presente. da techné que positiva no projecto a ausência de contradiçôes, de acidentes. Integridade, harmonia e clareza mas também ambiguidade, imperfeição, dissonância. Moholy-Nagy mas também Kurt Schwitters, Max Bill mas também Ben Nicholson.

Nos trabalhos que se expóem neste livro pressente-se o método cubista de destruição da forma como necessidade para se construir a realidade, a metamorfose entre signo indexical e marca pictórica, a dialéctica entre fisionomia e abstracção, o compromisso com uma representaçáo polifónica que vai muito além do aparente, que separa a visualidade do visível; num exercício de anamnese vislumbramos nestas maquetes, nestas imagens fortes, inesperadamente modernistas, os efeitos diferidos dos contra-relevos de canto que Tatlin apresentou pela primeira vez na exposição 0.10 , em Petrogrado; a lição da sala suprematista de Malevitch na mesma exposição 0.10 de 1915 assim como as primeiras experiências abstractas de Mondrian em 1911 reencontram-se nas composiçôes em que o orgânico (das mãos, das plantas, do rosto) é decomposto, desfigurado e reorganizado ao ponto em que cessa de se relacionar com o seu referente. Revemos nos exercícios desenvolvidos o mesmo tipo de combinação produtiva entre espaço e imaginação que Vladimir Krinsky desenvolvia com os seus alunos na disciplina do Espaço no Vhuktemas nos anos vinte soviéticos.

Há um outro aspecto desta aliança entre pedagogia, experimentação e investigação que tem sido praticado metodologicamente na disciplina de Desenho II e que as palavras de Le Corbusier que encimam esse texto como que

2 Gertrude Stein, Picasso, (1938), Lisboa: Vega, s.d.,p.22.

3 Gough, op.cit, p.117.

4 Giulio Carlo Argan, História da Arte como História da Cidade, São Paulo: Martins Fontes, 1998,p.19 

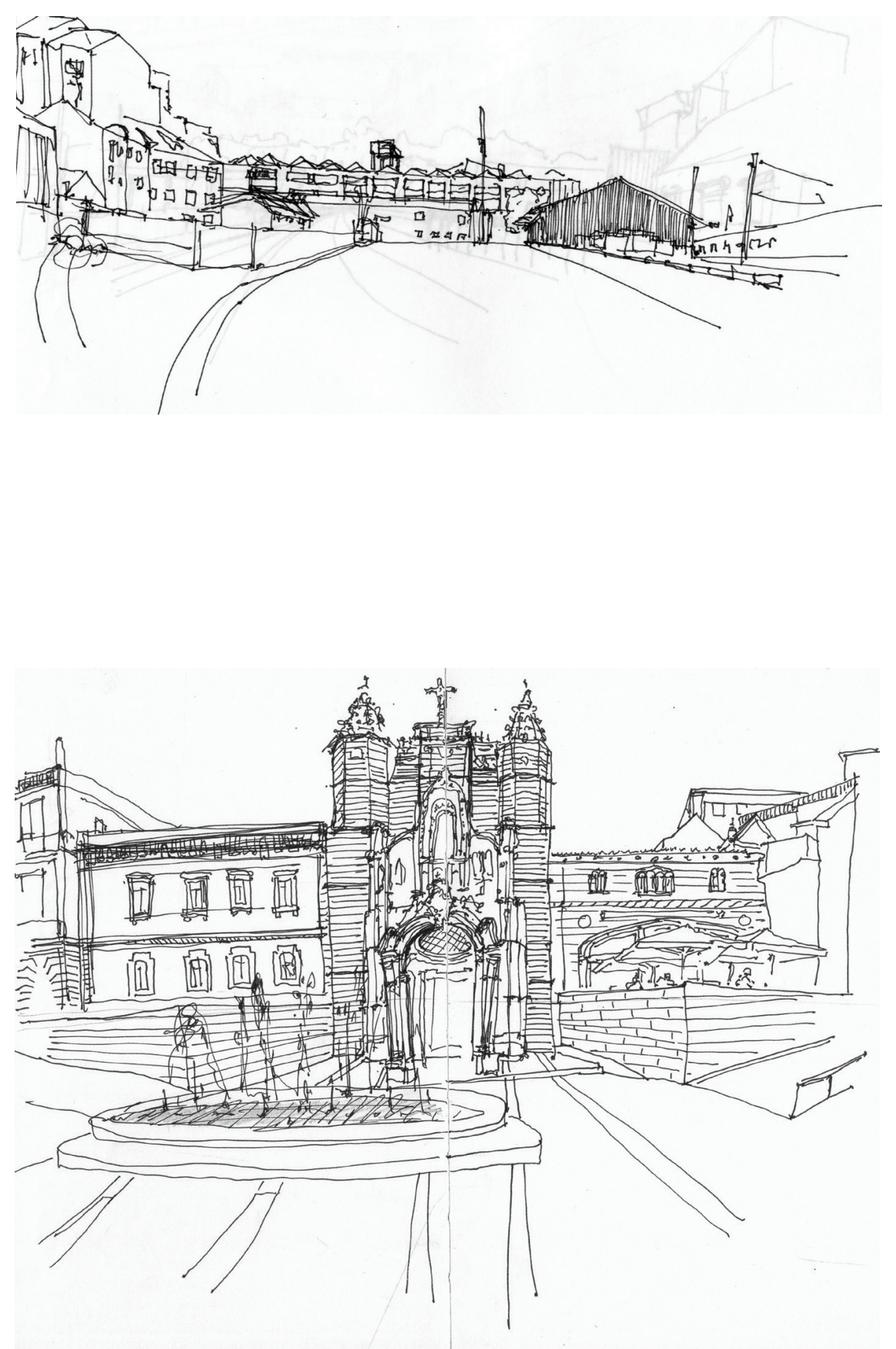
auxiliam a clarificar. A realidade oferece-se como poética e o desenho é um dos dispositivos, neste caso óptico-conceptual, que torna inteligível as propriedades criadoras dessa poética.

Sulco, rastro, curso, marcação, inscrição, traço; um reportório complicado de termos, que se podem associar entre si, enuncia o poder propositivo de um mesmo acto: o de fixar, congelar, suspender o real, o experienciado, o concreto (que tanto pode ser da ordem do visível e do não visível, do concebido e do não vivido). Desenhar é suspender o mundo numa composição, um mundo informe porque complexo, constituído pelo que conhecemos e pelo que não imaginamos sequer que conhecemos, um mundo com diferentes escalas e camadas de sentidos. Por isso diz-se que desenhar é conhecer, conhecer aquilo que sentimos com o olhar, com o nosso corpo, com o gesto táctil dos nosso dedos mas também conhecer o alcance das nossas possibilidades, a luta dentro de nós entre estereotipia e protótipo, entre o estranho e o familiar. O instante gráfico capta o modo como o tempo do desenhador, as suas motivaçóes, a sua energia, contactam com o tempo do objecto, da ideia, do conceito. É nesse sentido que, aqui, neste material o desenho apresenta-se como a concorrência entre esses dois tempos, fazendo saltar a realidade (até das coisas que não existem, que os alunos nunca viram) para fora do imediato.

O vestígio de uma presença no território, a mancha numa superfície parietal é das primeiras manifestaçôes humanas de objectualização do espaço (como ideia, como memória, como propriedade) antes que esse objecto, o mundo, fosse abstractizado, colocado num quadro, num dentro e fora de campo; o sujeito humano desenha para tomar "posse do mundo enquanto objecto". Este é outro aspecto que se denota do trabalho dos alunos de Desenho II: desenhar tem uma função posicional para a nossa subjectividade-estive aqui, estou aqui, este é o meu estado de consciência do mundo, este é a etapa em que me encontro no processo de conhecer e apreender o mundo como imagem; o desenho é como que uma autografia do estar no mundo e essa autografia existe como um gesto e como cinemática do corpo. O corpo envolve-se, mobiliza-se, converge para o esforço psico-motor da inscrição, do material riscador que sulca. Nessa autografia o desenho de representação é a definição de uma finitude (a forma que fecha o vivo e a experiência dos objectos numa imagem) e de uma segunda superfície (o fundo, o espaço que está de fora, o recorte do mundo no branco da folha). O pôr em cena o real através do registo de observação implica enquadrá-lo, significa centralizar no quadro de representação aquilo que se decidiu tornar imagem: um ambiente construído, um grupo de formas vegetais 
arbitrariamente dispersas no chão de um jardim, um indivíduo posando para nós; significa também confrontar experiência e memória, confrontar a história deferida dos modos de desenhar, a didáctica do desenho, com a psicologia do instante em que o observado se torna signo, confrontar a liberdade do gesto, com os seus limites e repetiçôes. Nos dois anos de Desenho que definem o curriculum do Darq é no segundo que se ensina de um modo mais continuado que enquanto prolongamento da presença no tempo, enquanto documento, a representação pode ser inferida antiteticamente como registo do observado e como projecção do pensado. Ela funciona duplamente como gesto e evolução interpretativa do que nos rodeia (e do modo como conhecemos) e enquanto depuração mimética pois é um acto de exclusão que desagrega a parte do todo, que mobiliza e intensifica porçóes do real (e do imaginado) em detrimento, em necessária oposição em relação a um contexto.

Concluo com estas palavras de Alekasandr Rodchenko que parecem extraídas do ambiente de trabalho da nossa disciplina: "Milhares de vezes eu pensei que a não-objectividade deveria ser elogiada porque graças a ela nós passamos a "ver" massas de objectos novos, de objectos que até podem ser velhos, ordinários mas cujas qualidades extraordinárias permaneciam ocultas, ignoradas."

Pedro Pousada

5 Aleksander Rodchenko, ( Alexander Lavrentiev, Ed.), Experiments for the Future - Diaries, Essays, letters, and other writings, Nova Iorque: MoMA, 2005, p106. 

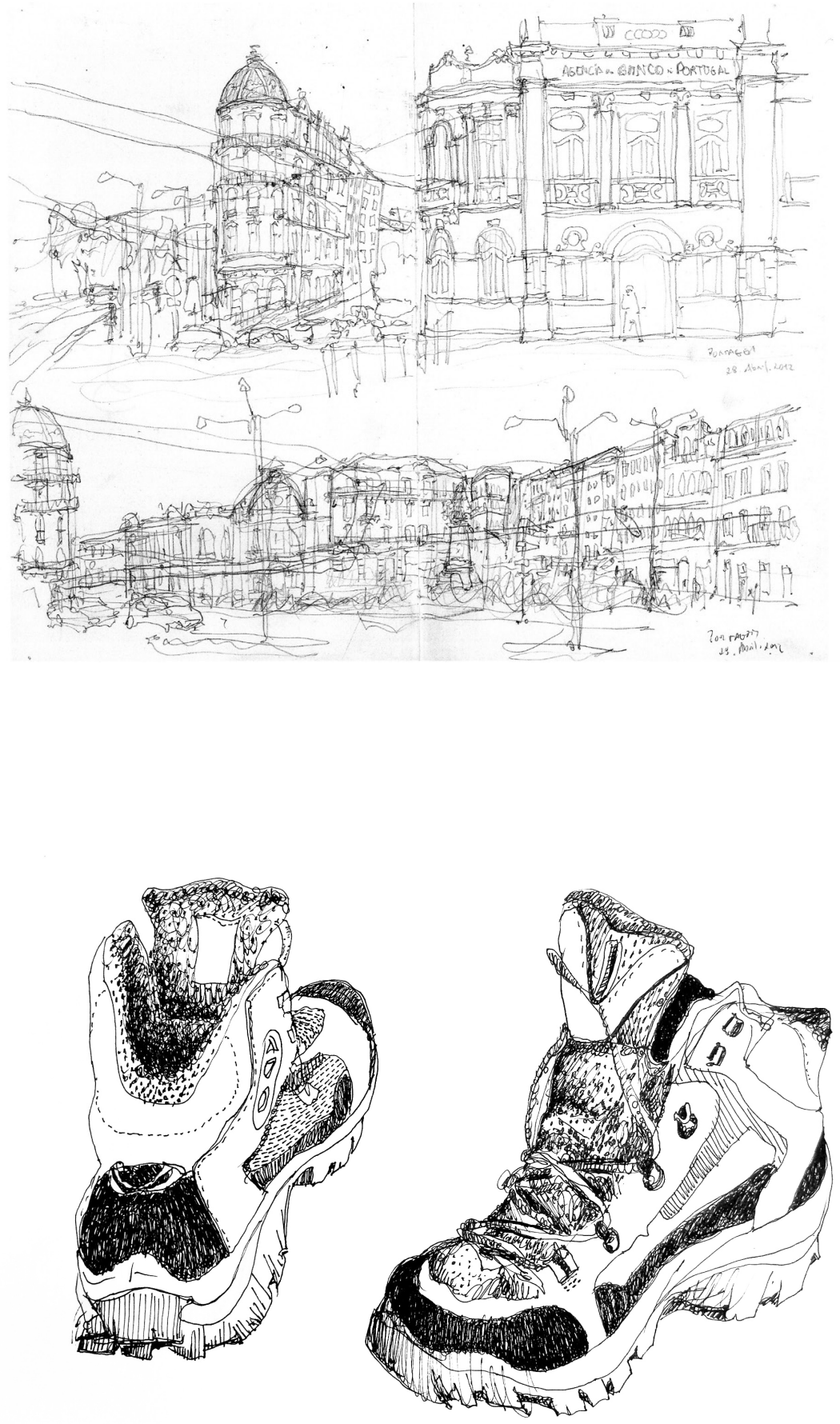

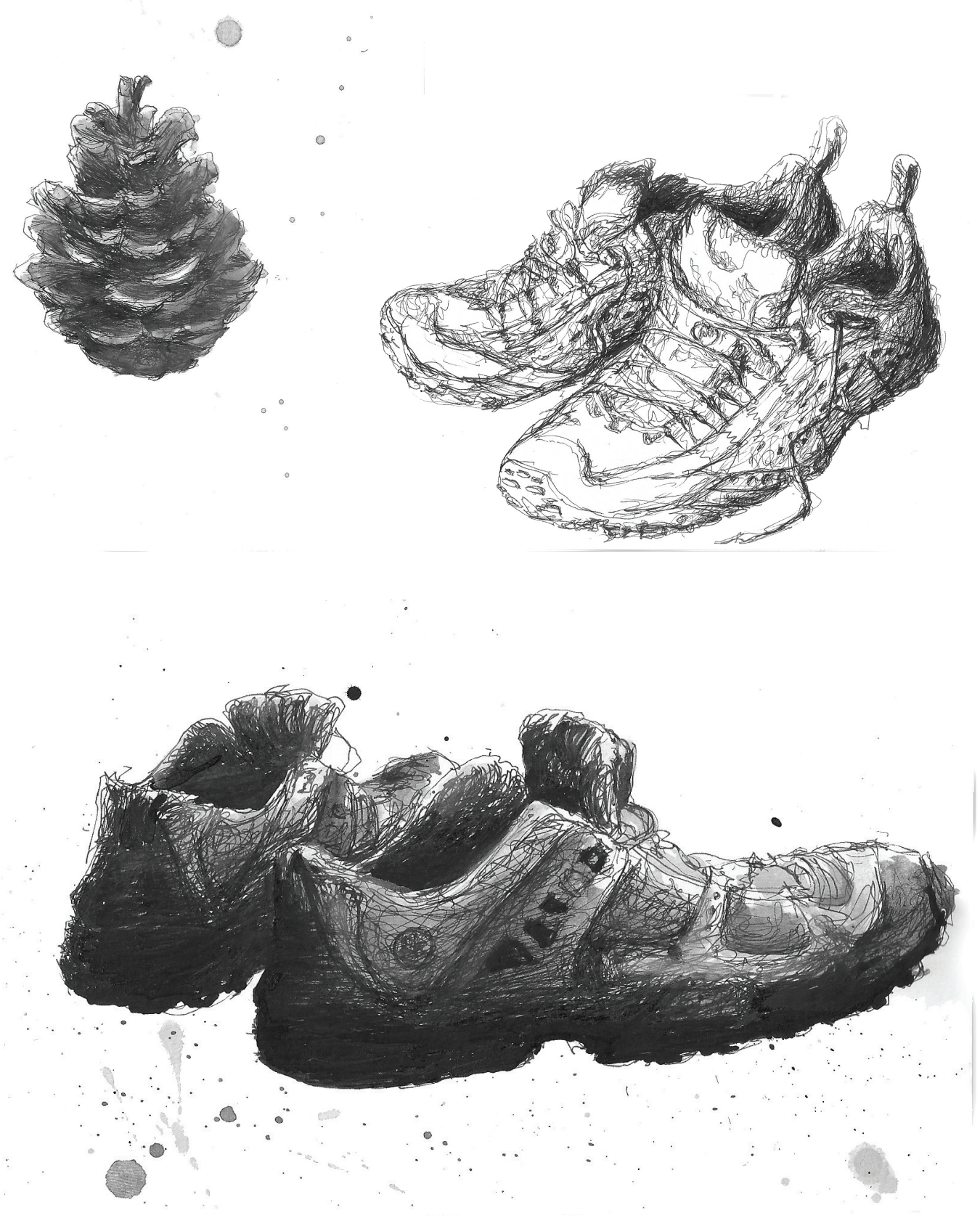

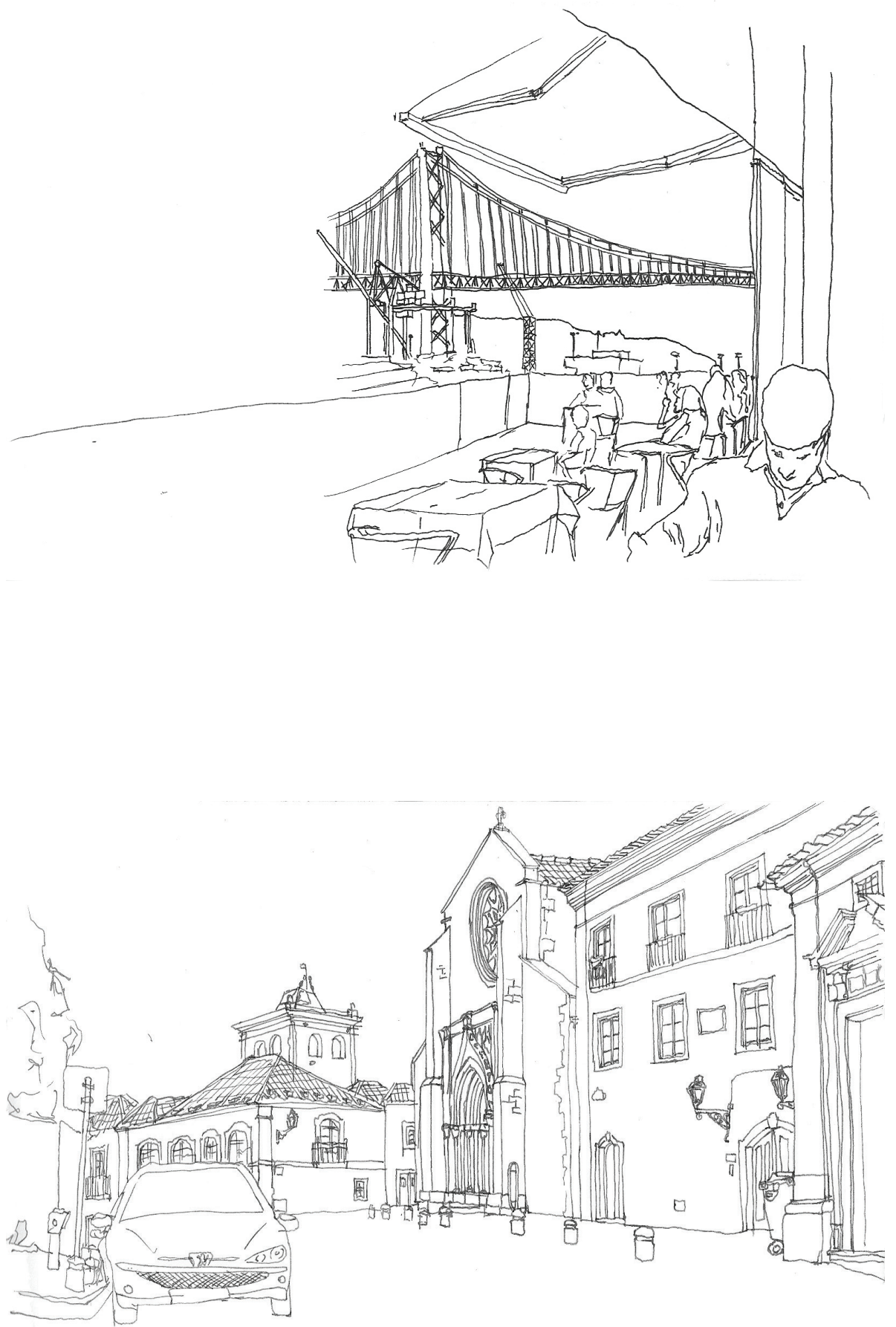

Pedro Caiado 

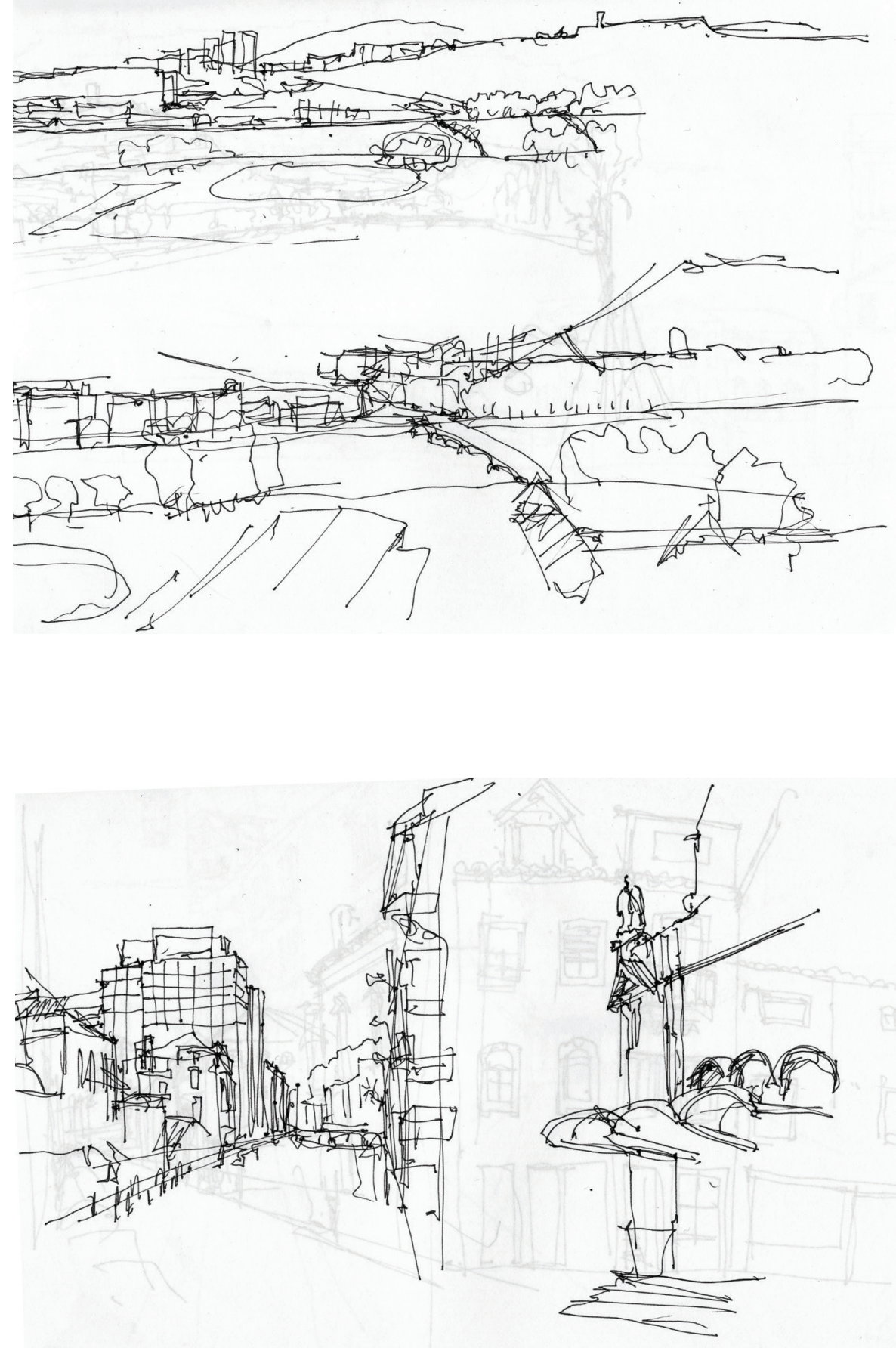

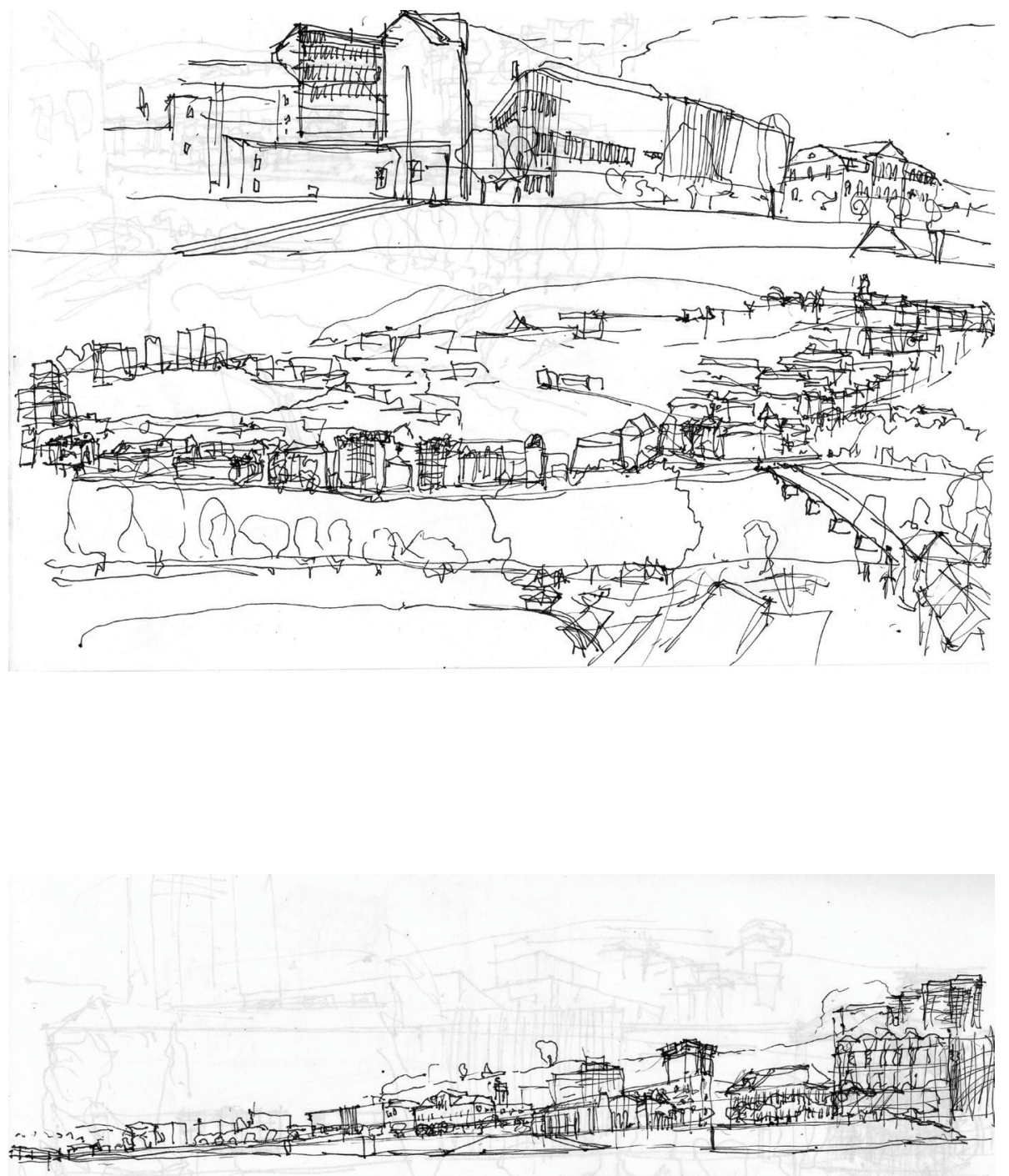


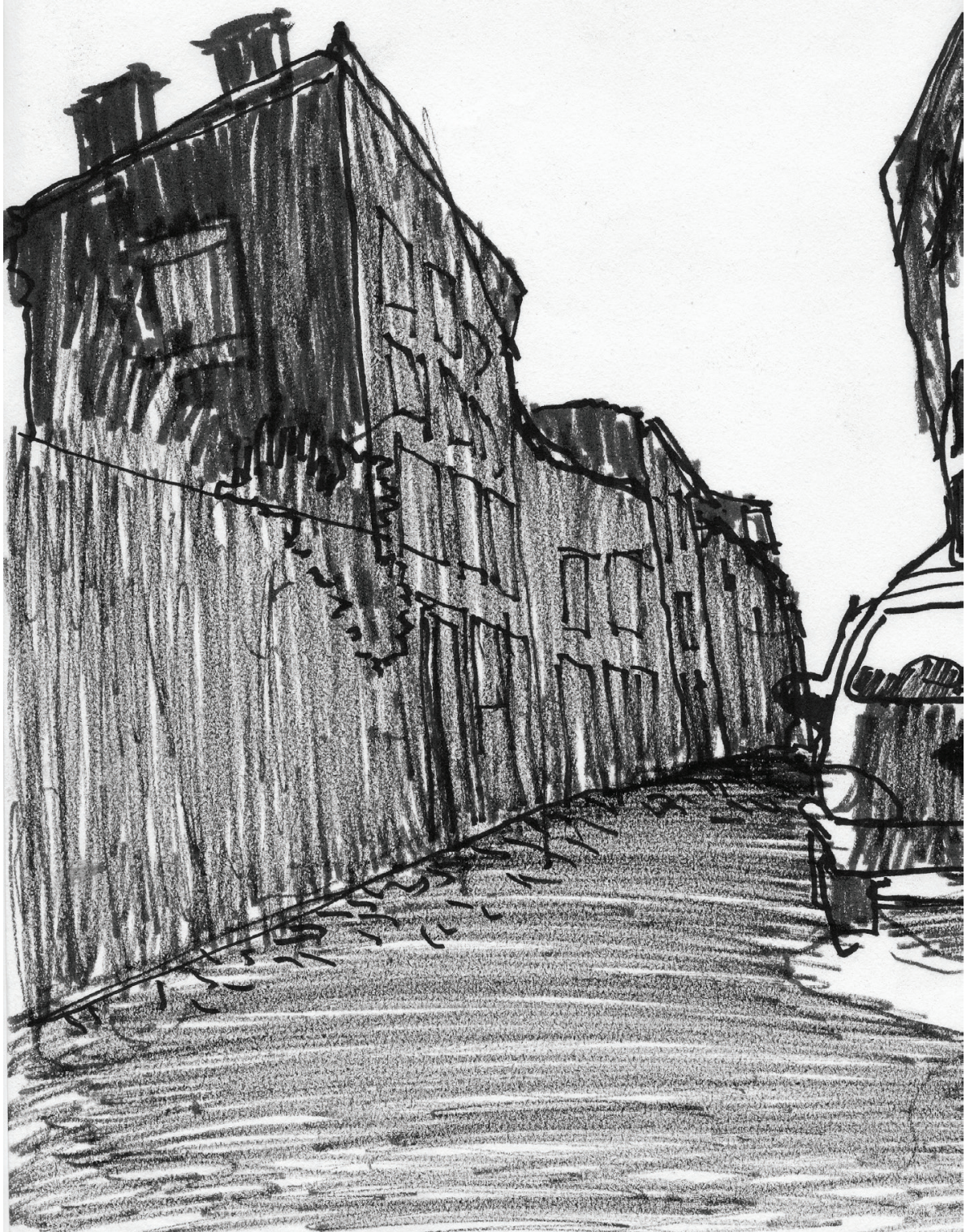



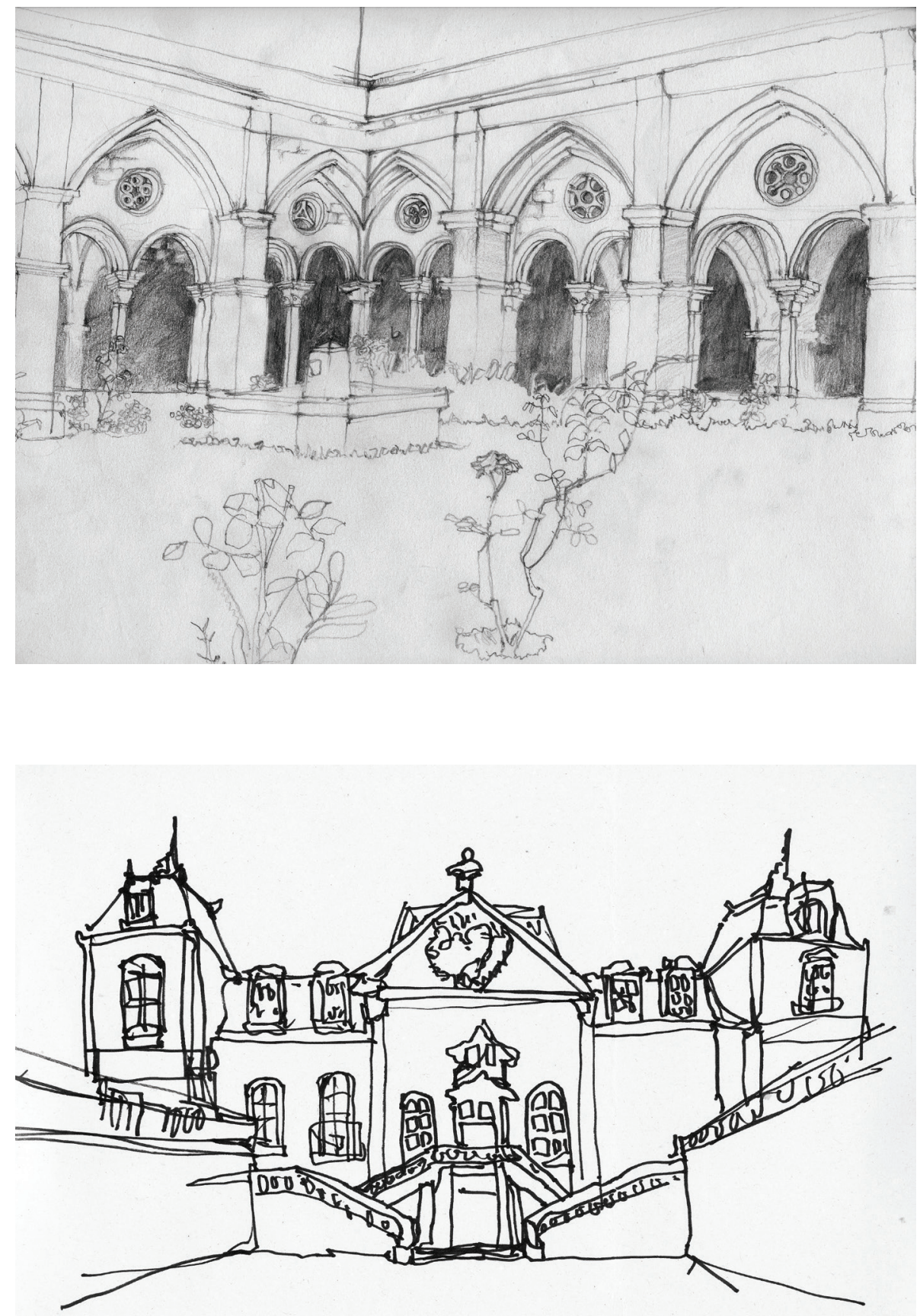

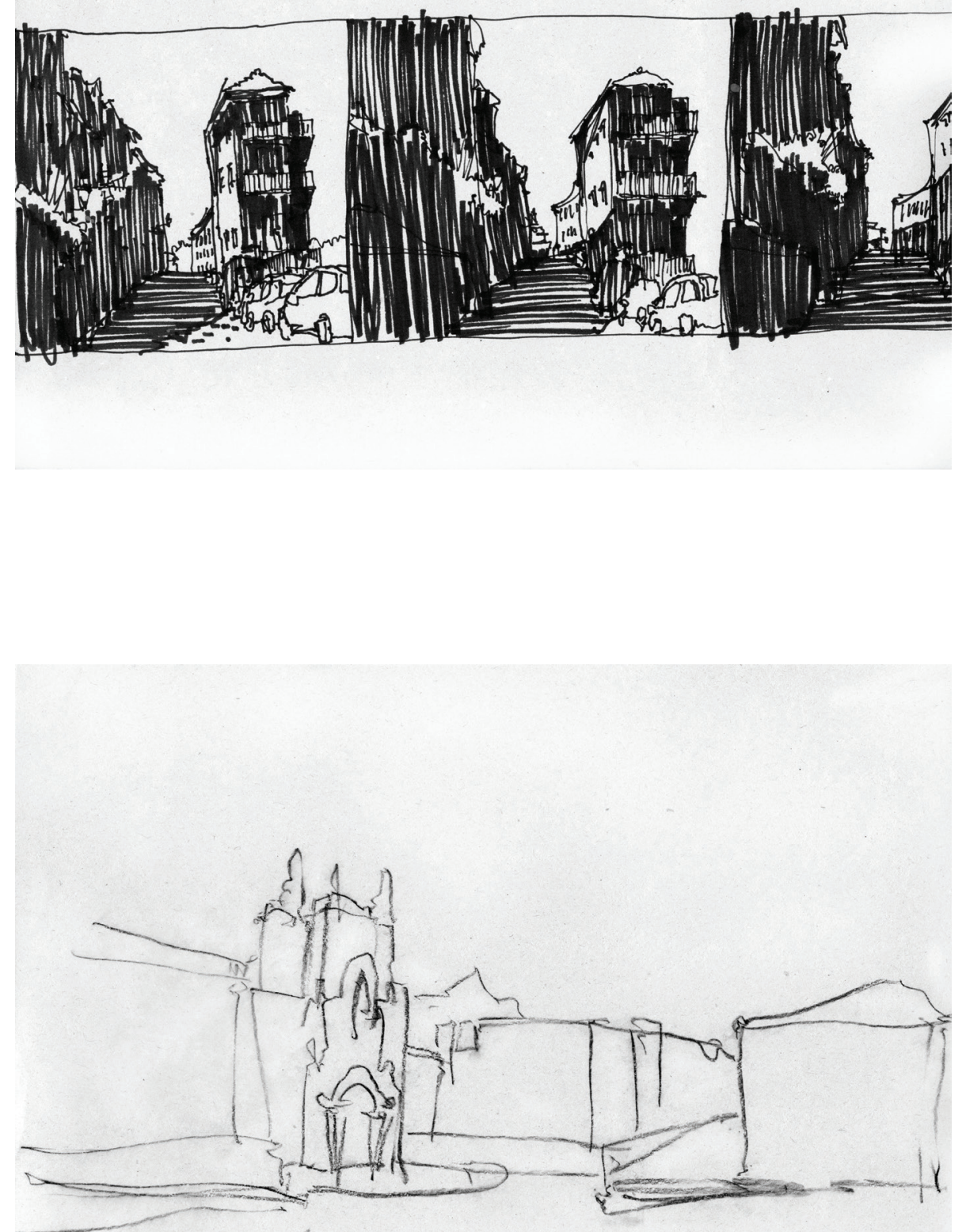


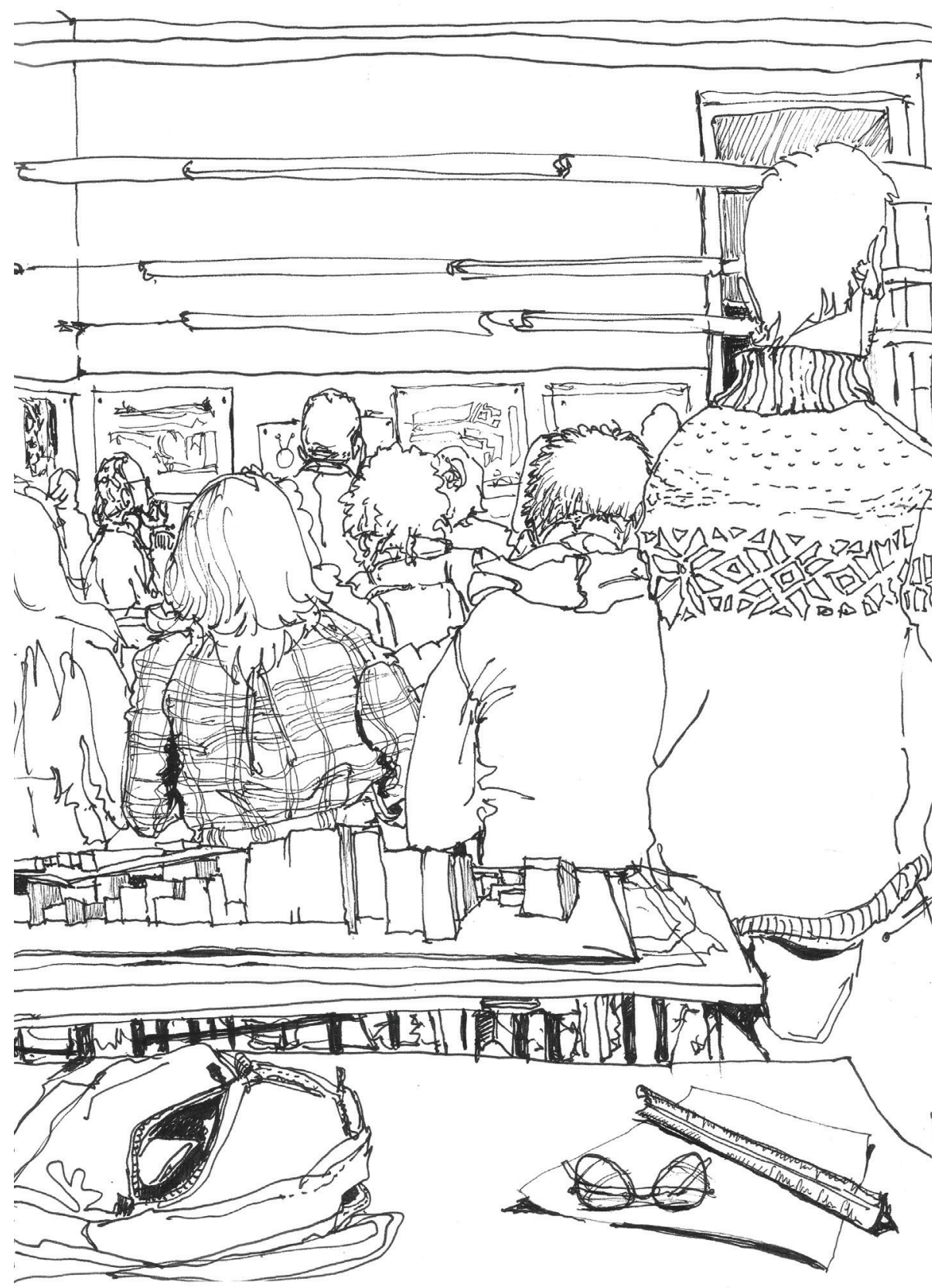




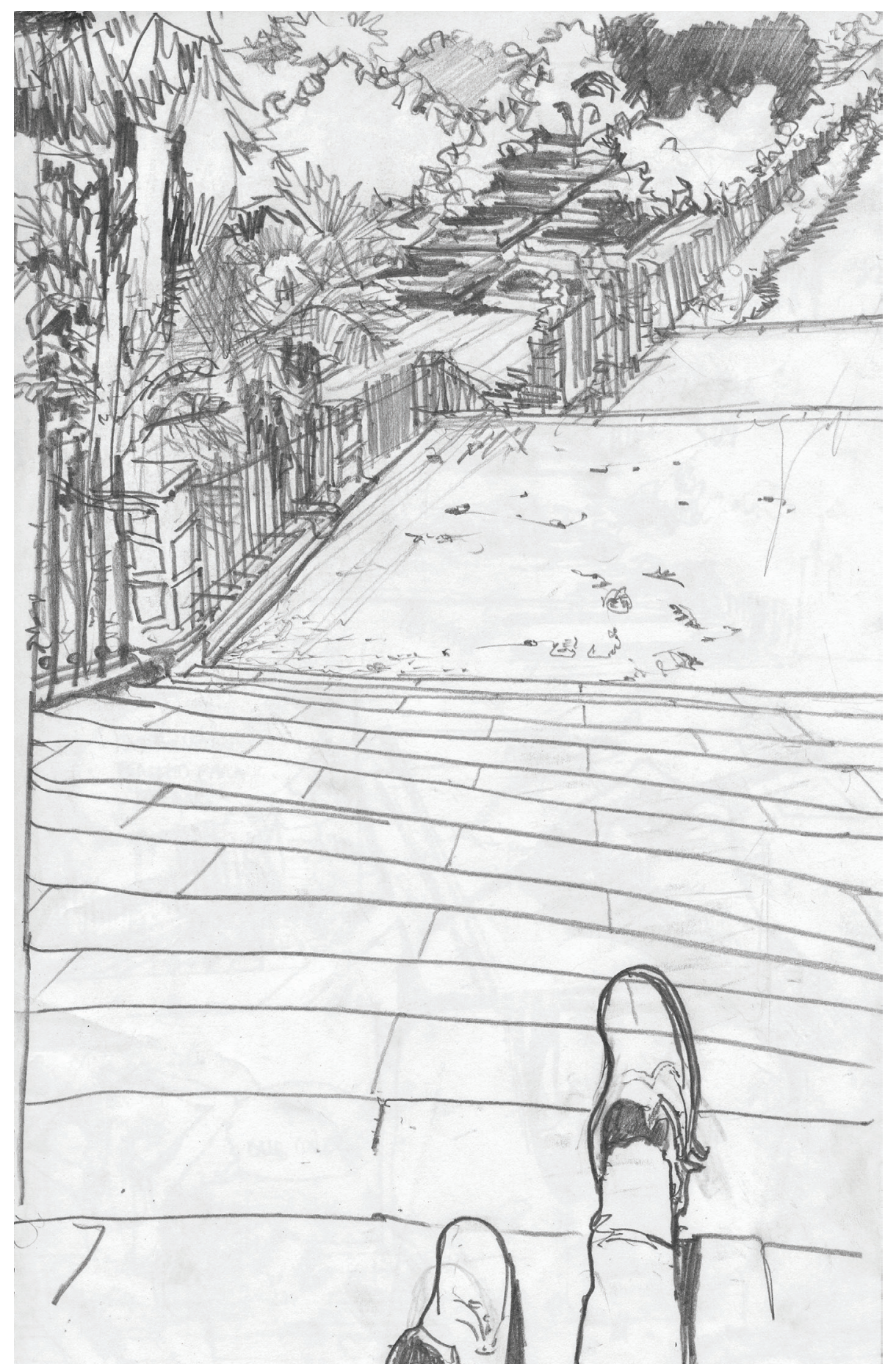




\section{DIÁRIOS DE BORDO}

Um caderno de desenho pode ser um instrumento precioso para desenvolvimento dos processos projectuais, sobretudo quando o desenho se desenvolve na gestação de novas formas.

Em processos em que as formas têm de se abrir, de divergir, contaminar-se com outras, antes de procurarem sedimentar-se em soluçóes finais ou definitivamente inacabadas, a coexistência destes desenhos num mesmo caderno não só dá consistência física às dinâmicas de concepção como as catalisa e as torna possíveis.

De certa forma, é como se o cérebro de quem desenha se projectasse nestas páginas, ou melhor, como se estes cadernos tomassem o lugar do cérebro, ganhando a necessária autonomia, indispensável à concentração.

$\mathrm{Na}$ sequencialidade das páginas de um caderno de desenho não estarão propriamente registados pensamentos que se organizam linearmente. Cada página parece não chegar para as imagens que se desenvolvem em todas a direcçóes. Parte-se para outra página porque o espaço não chega. Mantém-se a ligação com as páginas precedentes, procurando resistir a qualquer descontinuidade no pensamento, mas aproveitando cada passagem de página como pausa e ponto de situação. 
(Página deixada propositadamente em branco) 


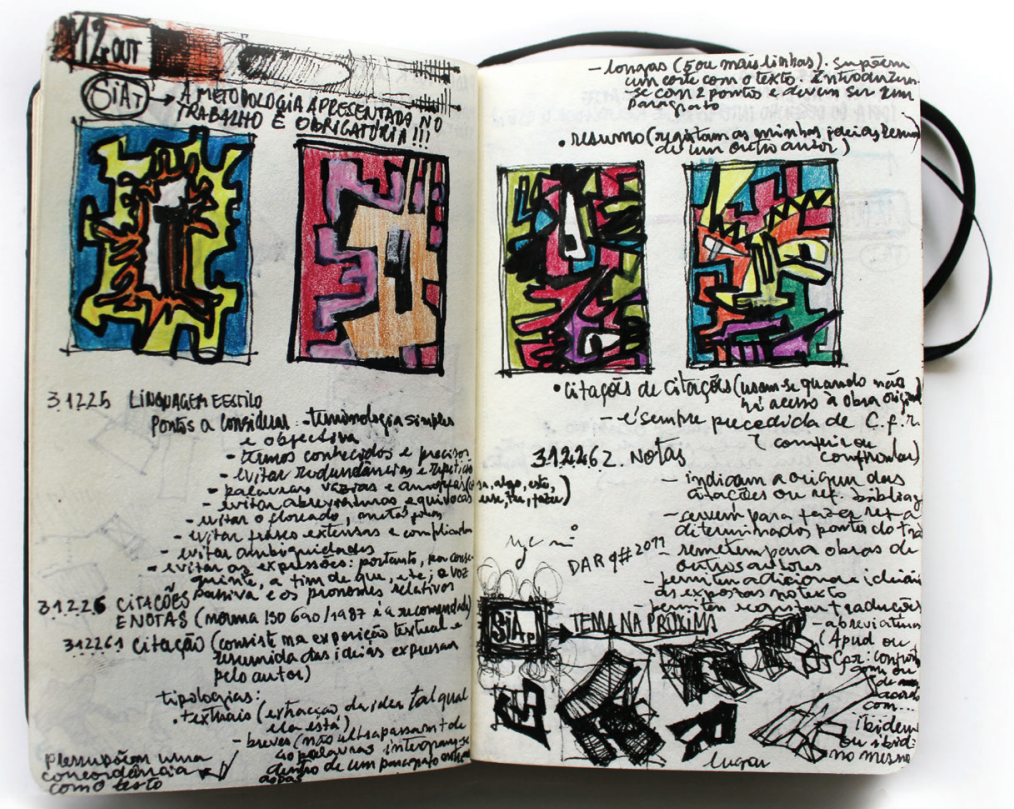




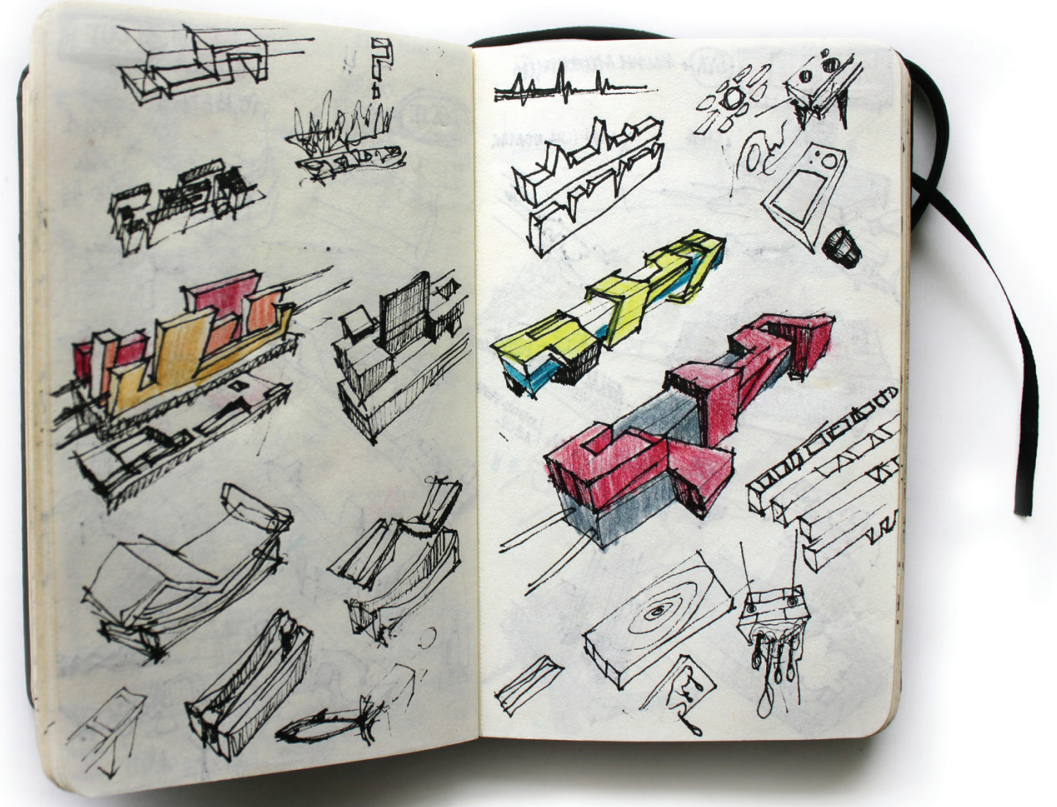




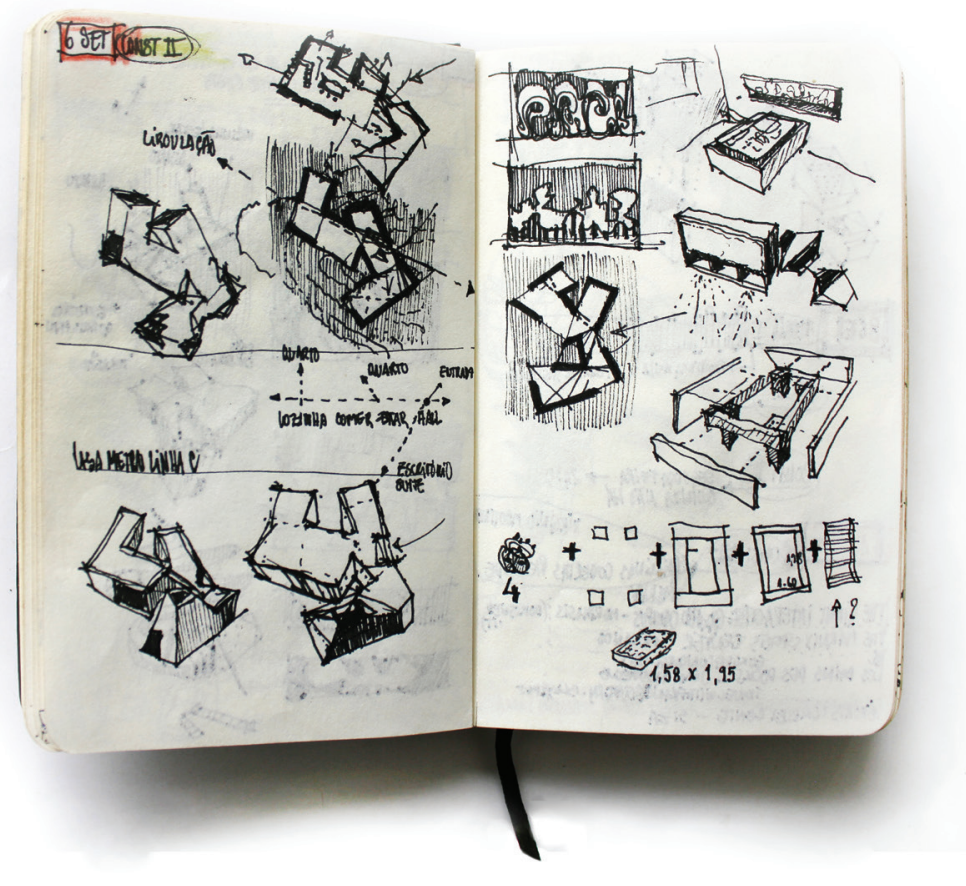




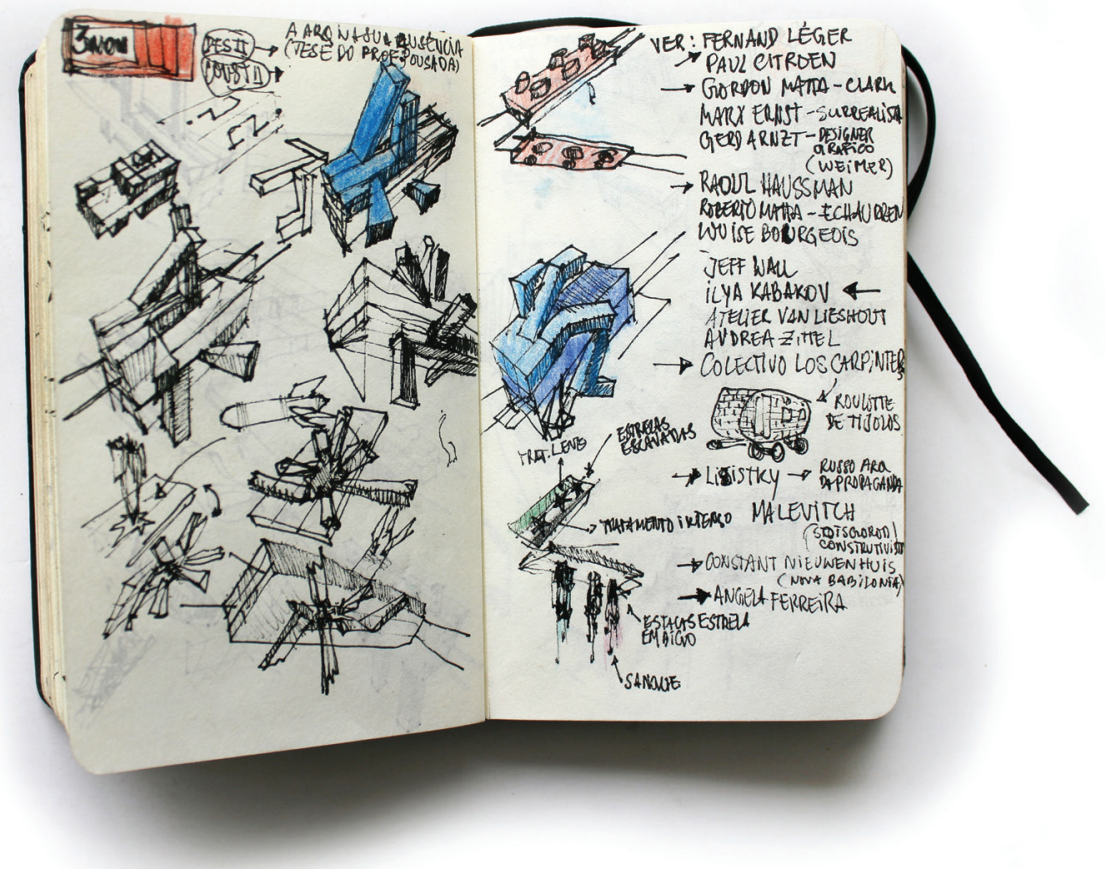




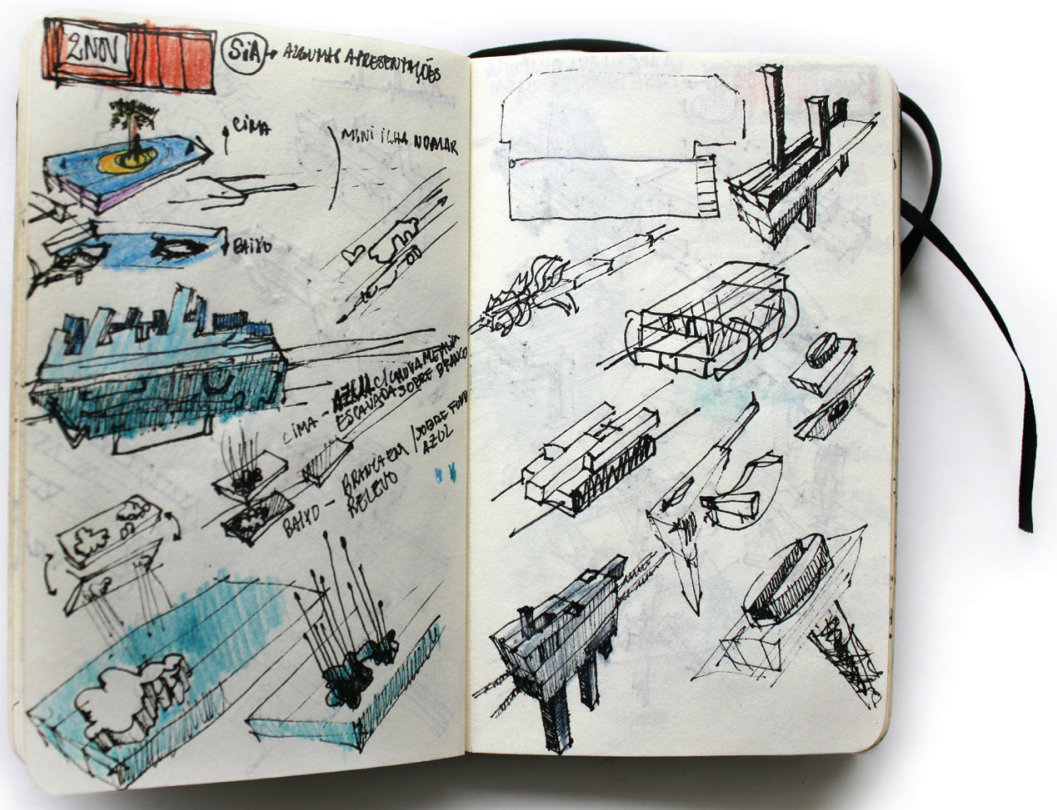


31.223 Numeraces

31224 a mumeraco de sel árab. Redaccós (émporicas torm dos dacos recelki dos? - otuma devers herfritament estan - Os es reumas de cardintas capilue devem etiai bein disinidos - sicominenda ie a clatur

31224 kidaceño (experiops tomal dades recollutols?

312241 primes ra cloloce,ā̃ - privilh cin ocontuldo a deteimento do estilo una idica per ponagit" lesiriar citagool noty 312242 Gutis redacests - apeimasar 1 kh - dar a en a tuan. Civ Ropraqueir Sexpa 15:30 $\mathrm{T}_{2}$ ( Sinp

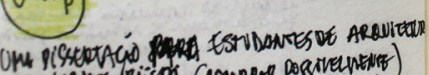

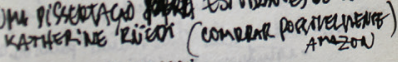
Whoos, custivent, rastavi

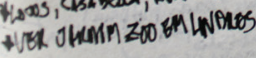

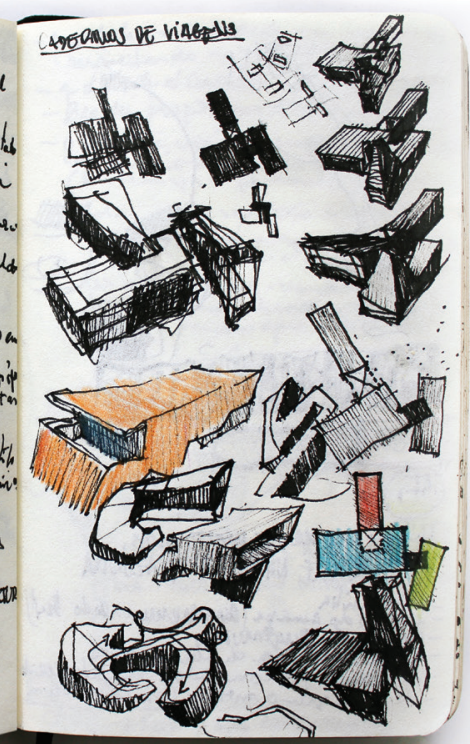




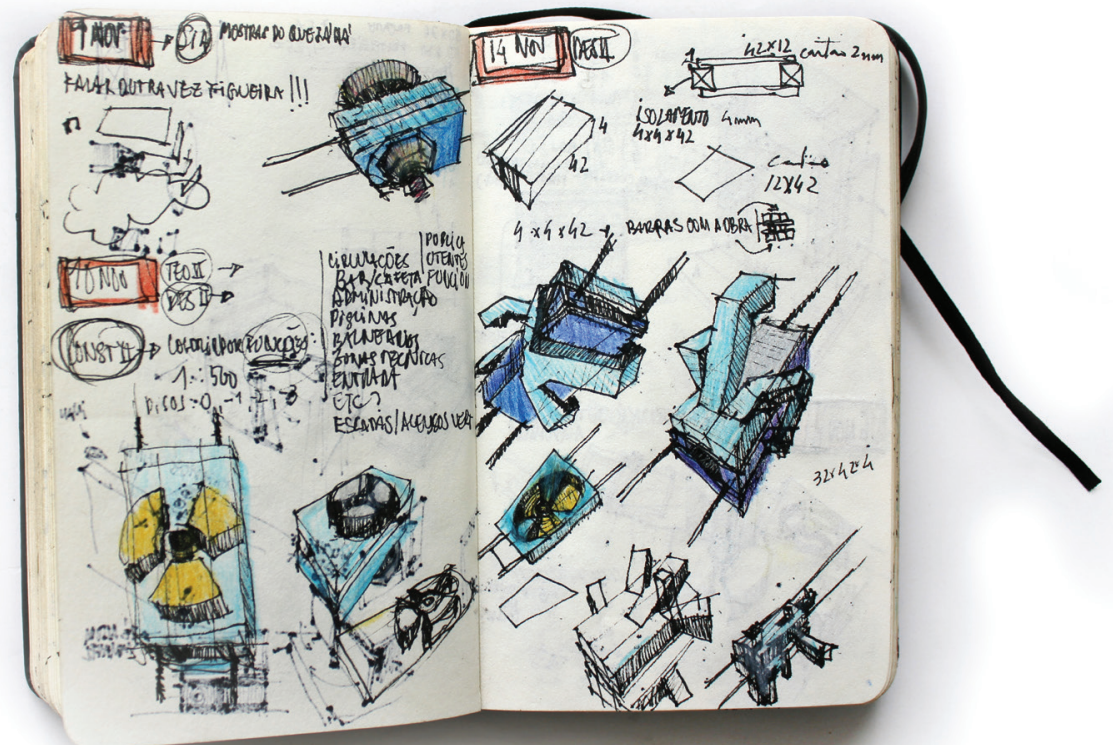




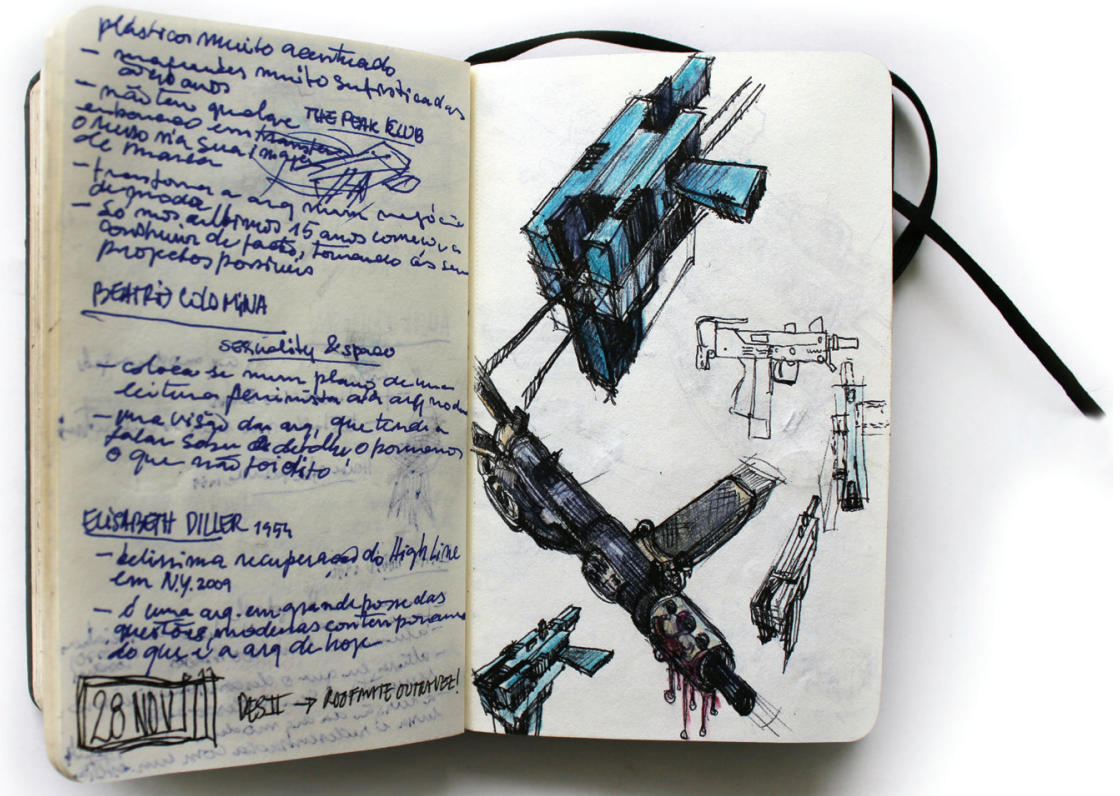




\section{NARRATIVAS FORMAIS}

Nestes exercícios, os alunos partem da banda desenhada não propriamento como ideia condutora dos seus trabalhos, mas vão buscar a ela a possibilidade de estruturar o suporte, de o fragmentar, de forma a poder dar lugar a simultaneidades de espaços e tempos. Desenhos de condição ubíqua, mas também desenhos que se desenvolvem em sequencialidade temporal.

É a plasticidade que estas estruturas permitem que aqui é explorada. Mais do que instrumento para a narrativa, é o próprio campo de possibilidades formais que aqui é explorado. E pertencem a estas possibilidades formais não só os aspectos visuais, gráficos, compositivos do desenho, mas também as relaçóes conceptuais estabelecidas. Plasticidade que se desenvolve na consciência da estrutura que organiza os desenhos, sendo esta muitas vezes a protagonista da composição, mas também nas relaçôes entre ideias que os desenhos evocam.

É desenhado o campo em que os desenhos acontecem. O campo já é desenho, em desenhos que criam as suas próprias condições de existir. 
(Página deixada propositadamente em branco) 


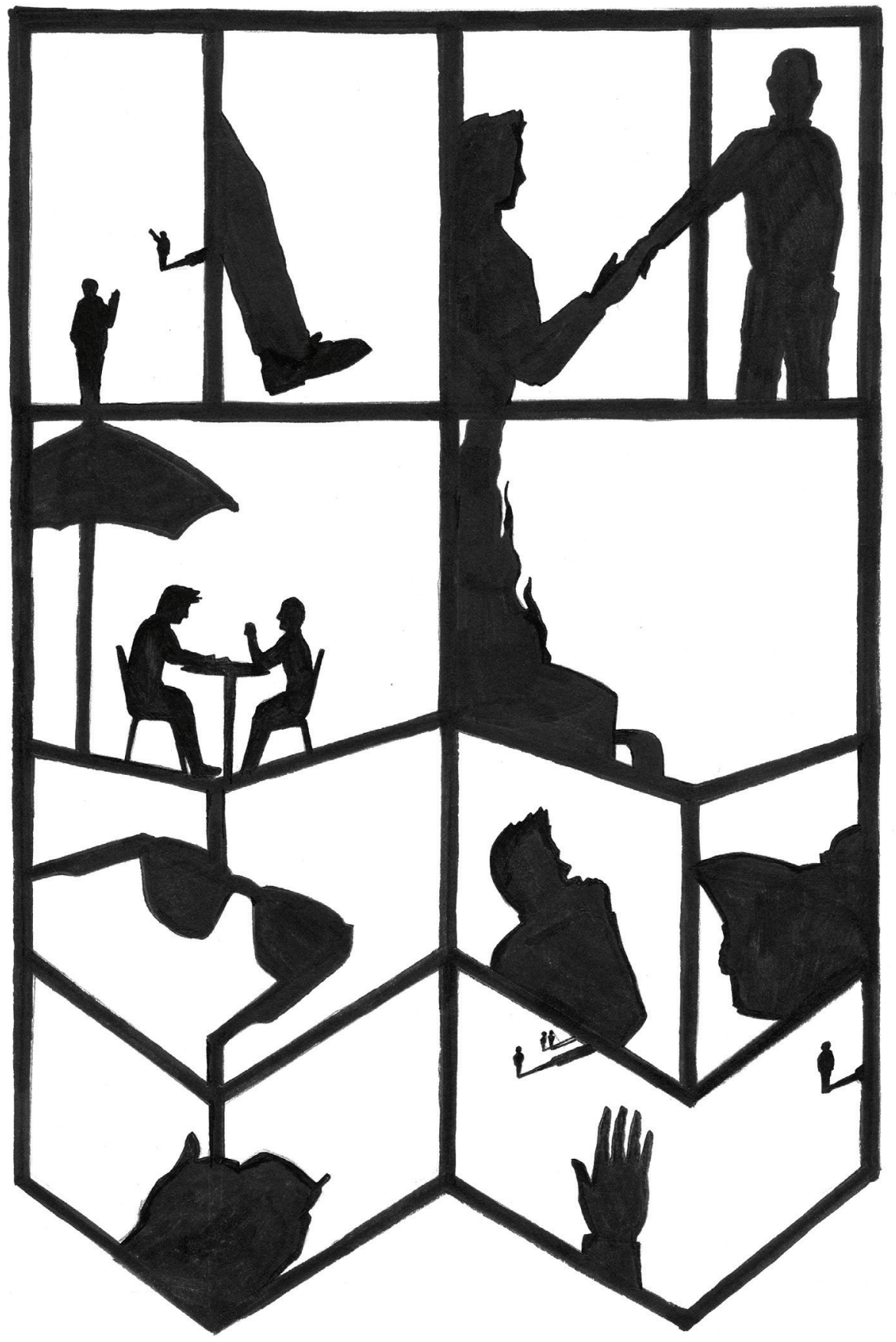



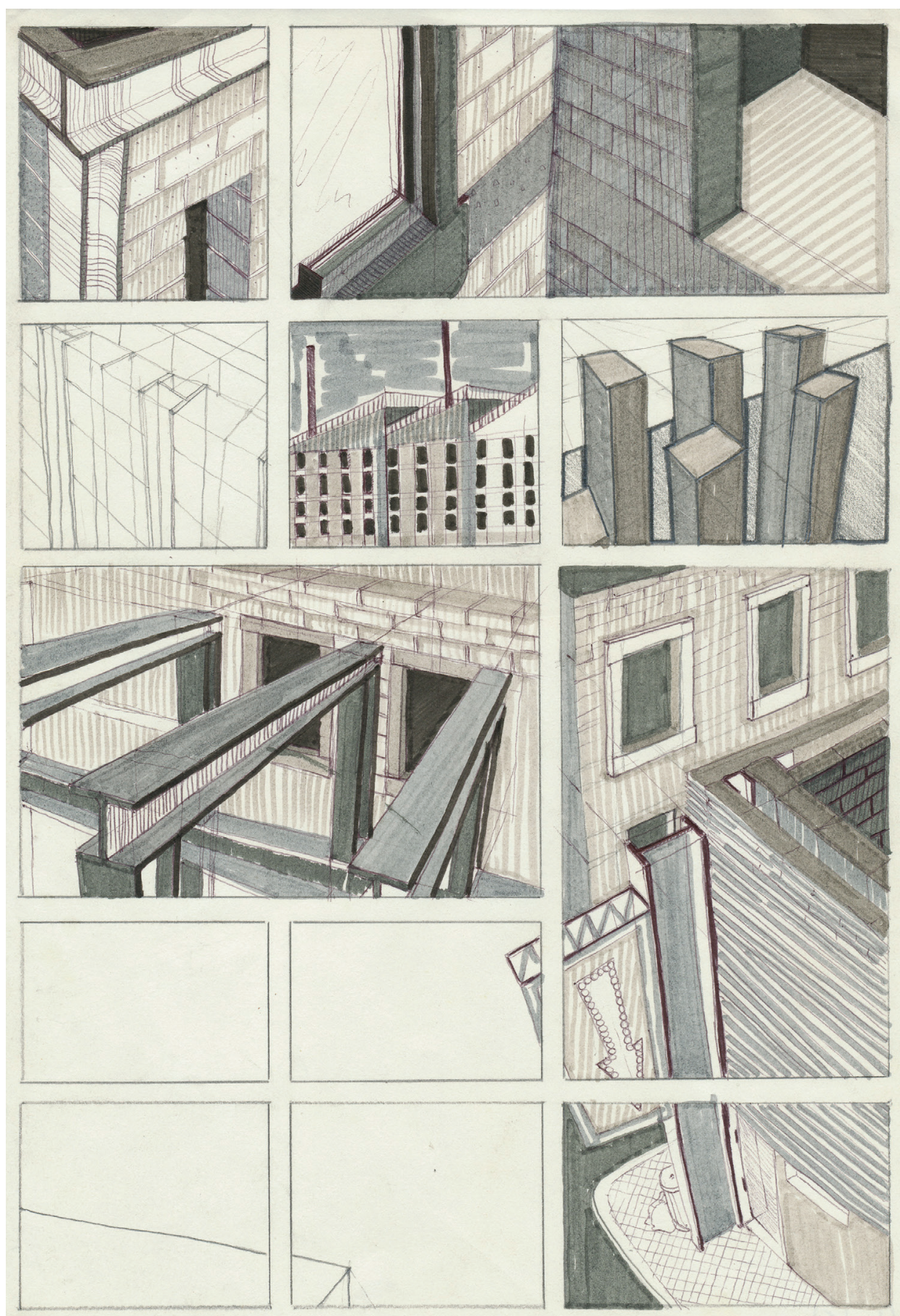


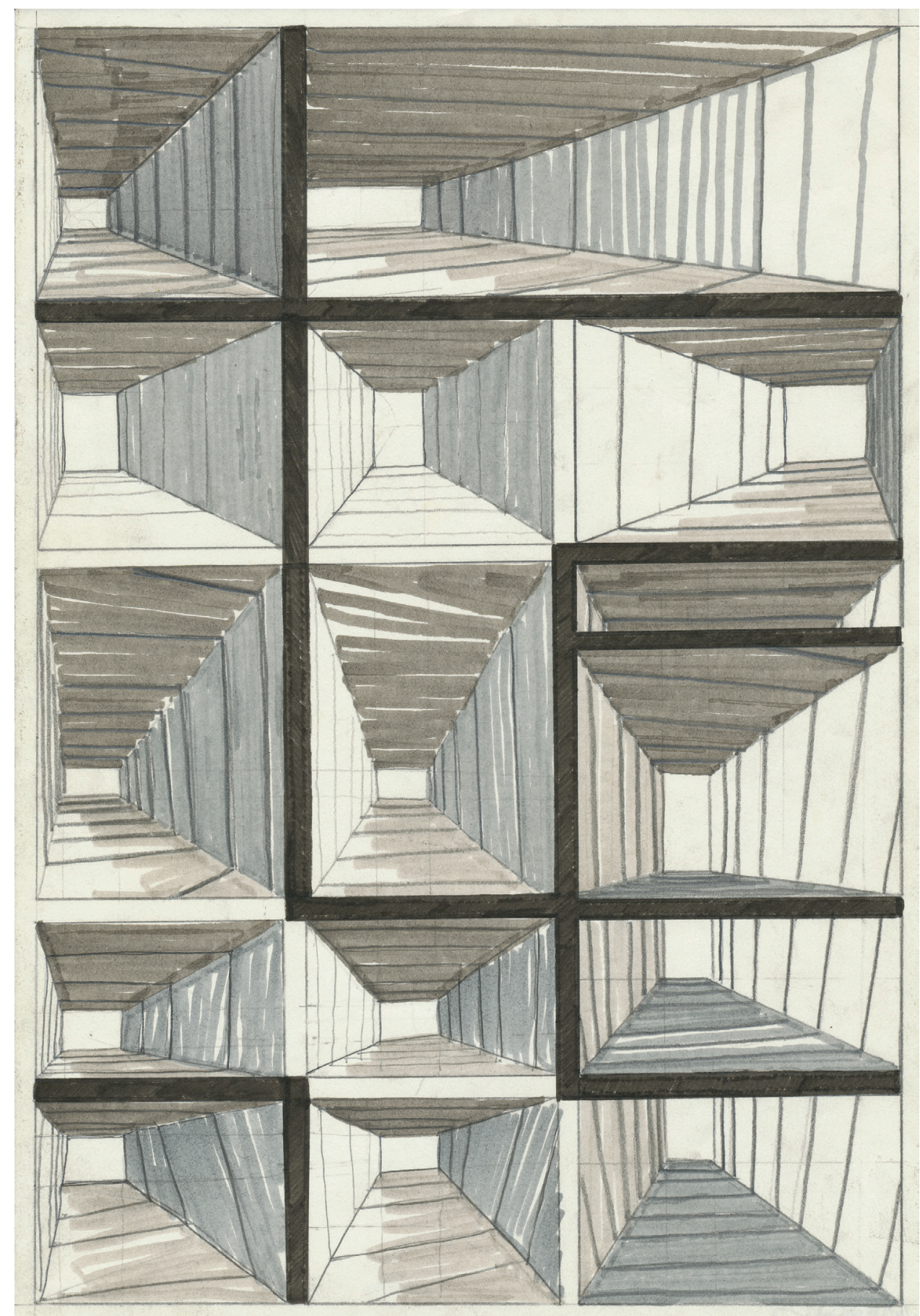



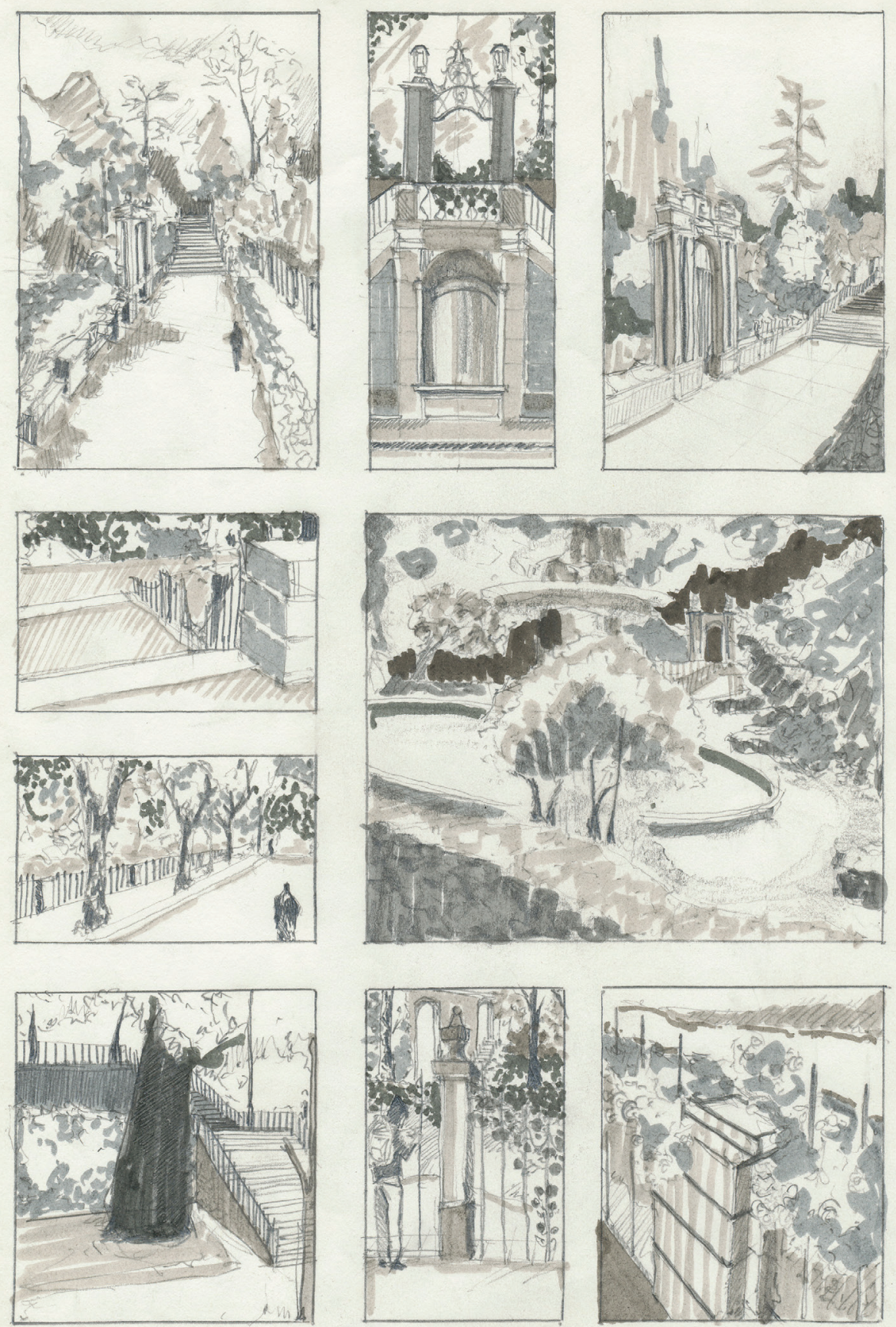

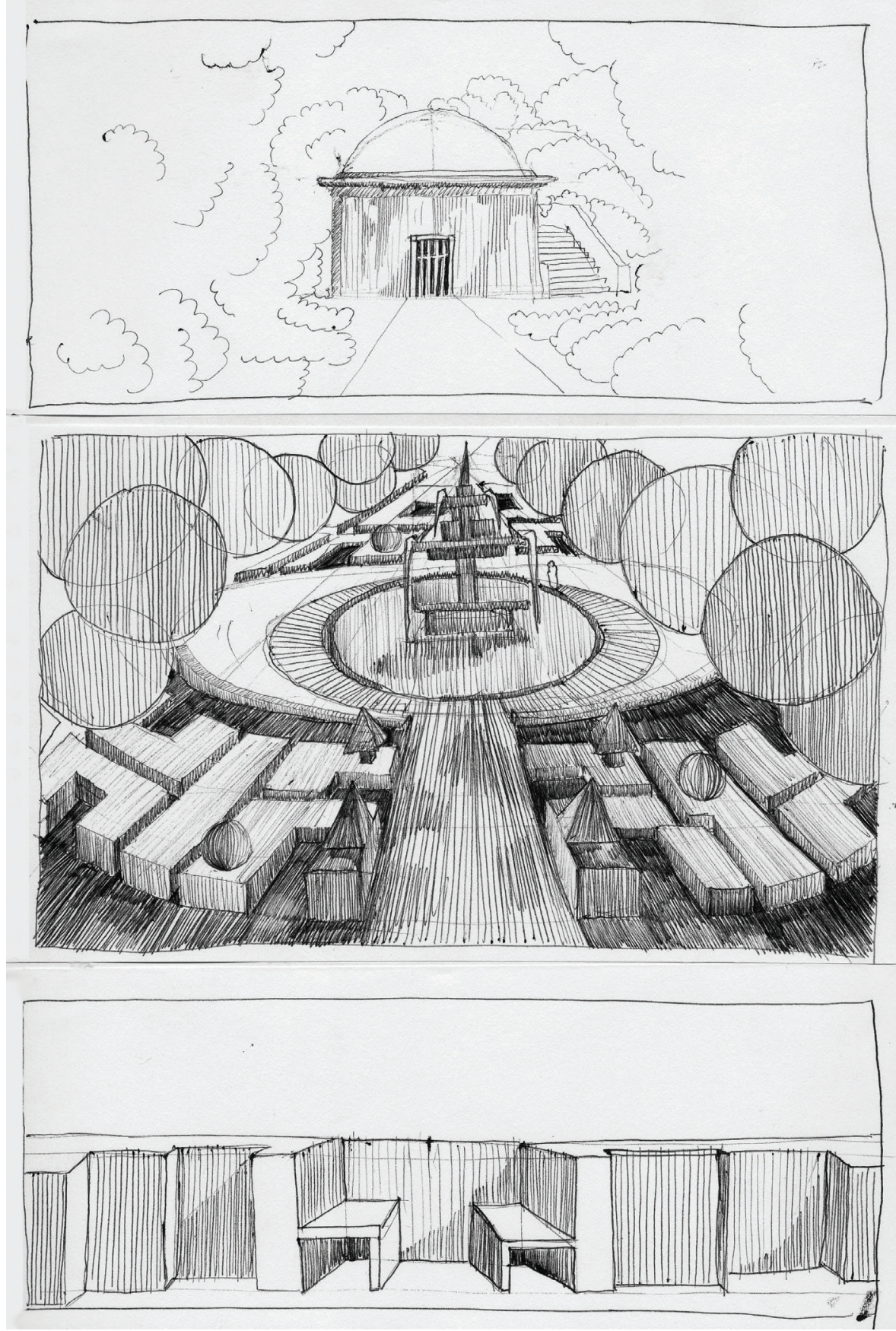

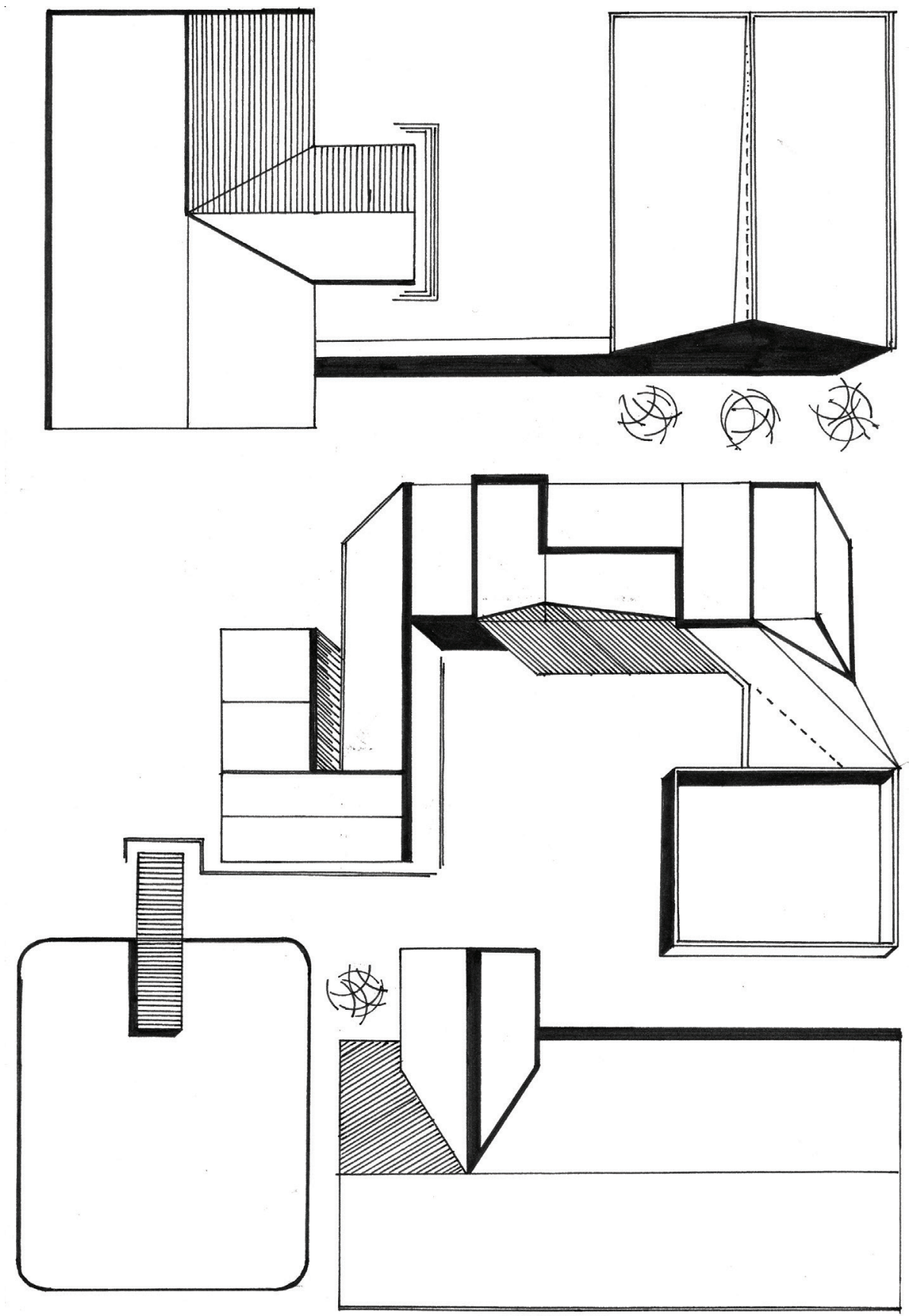

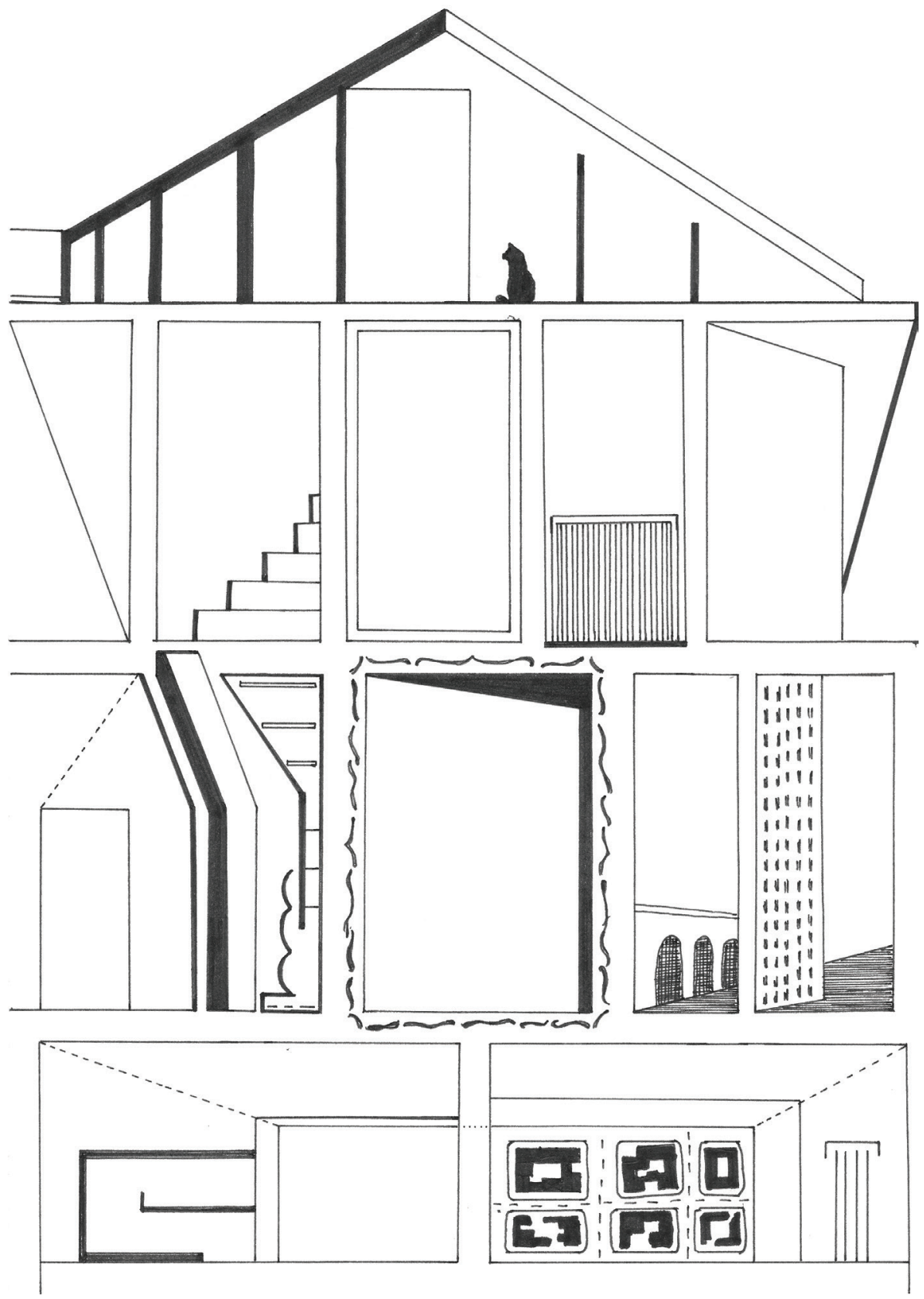


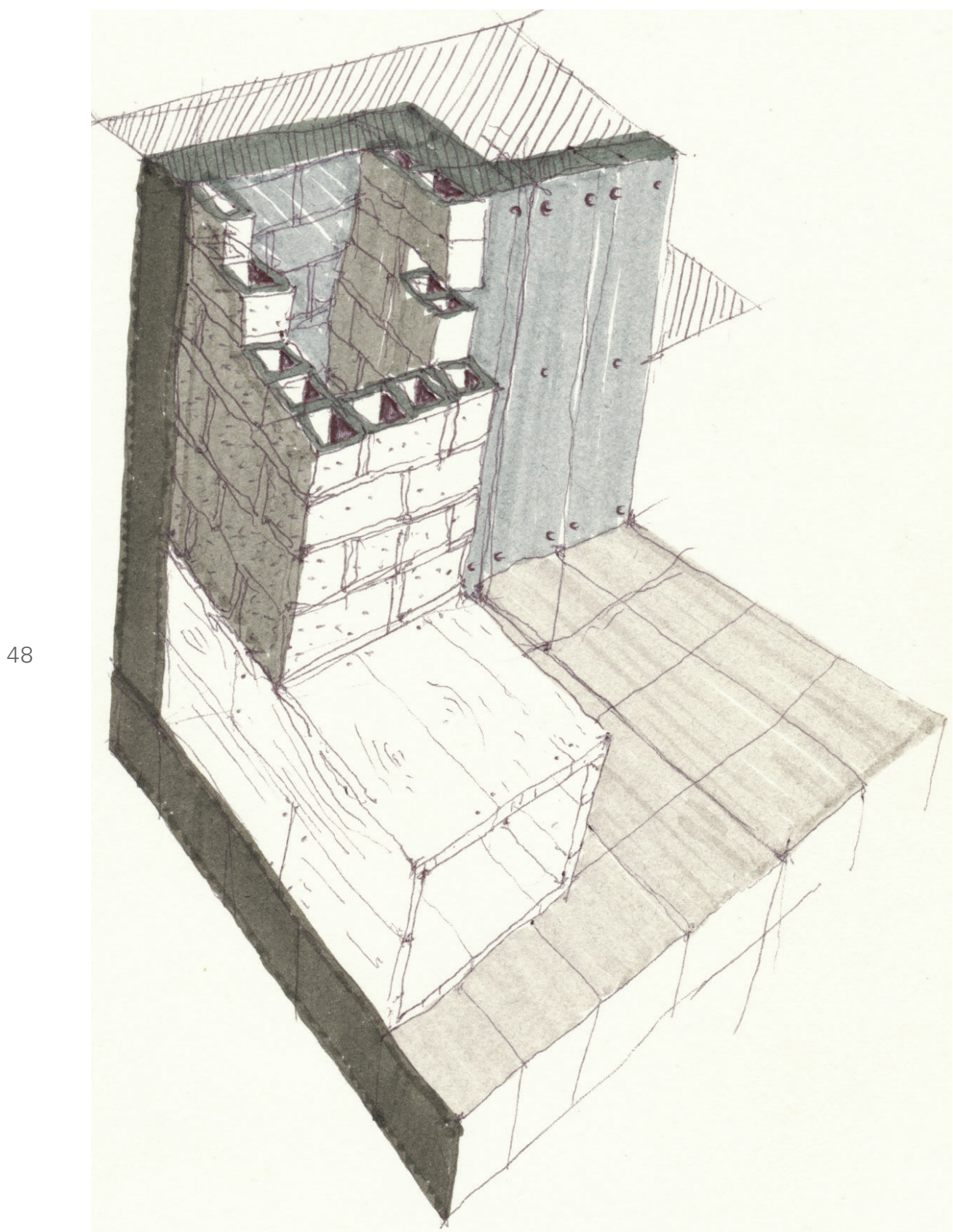




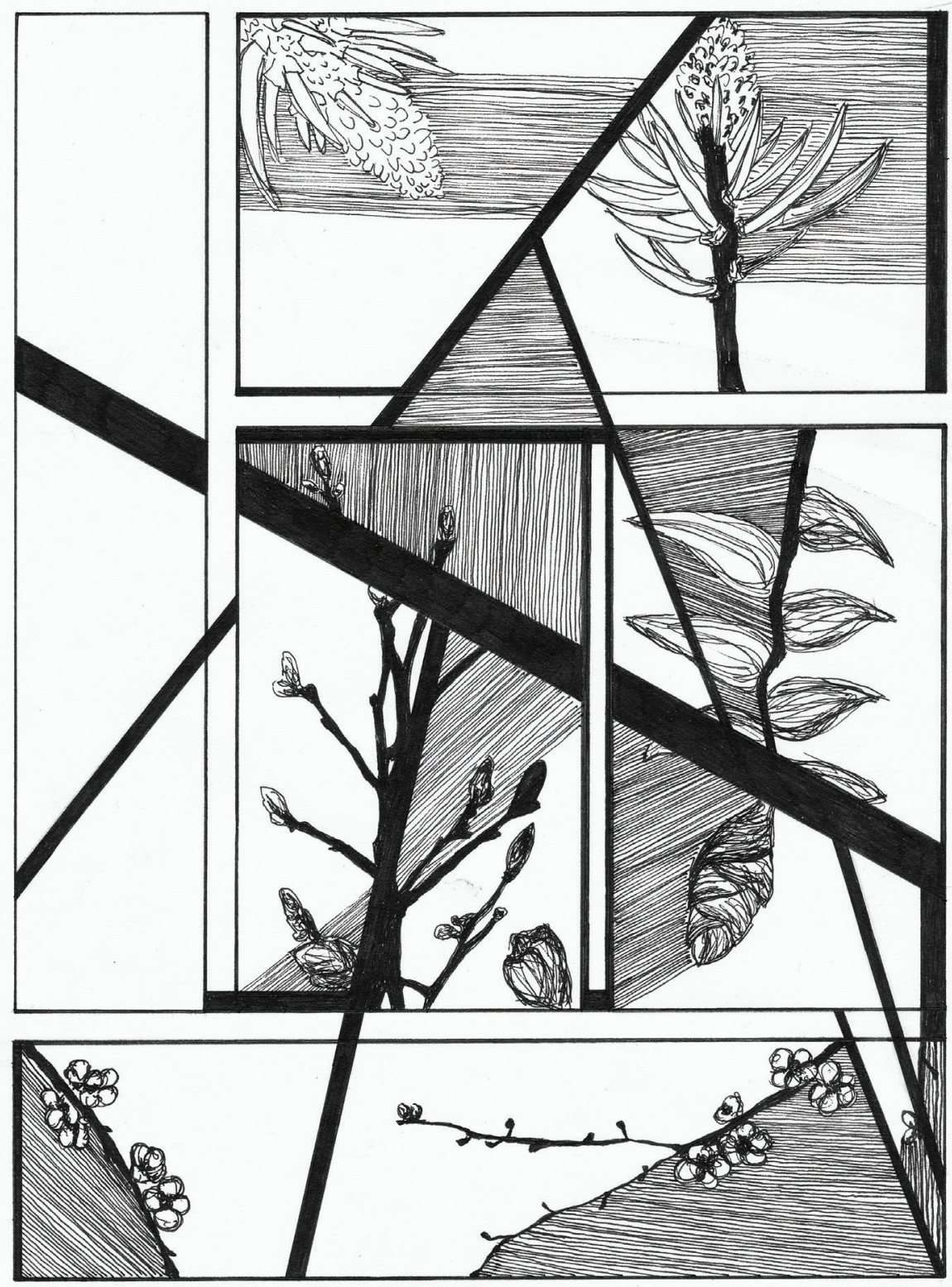



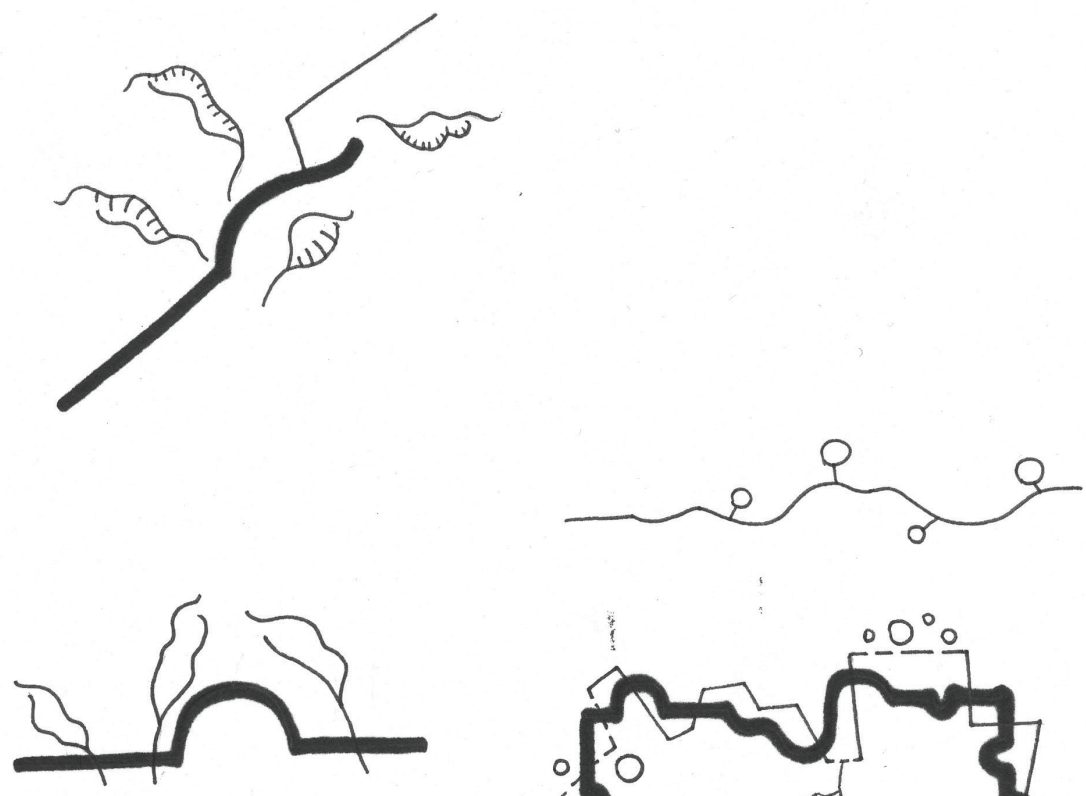

50
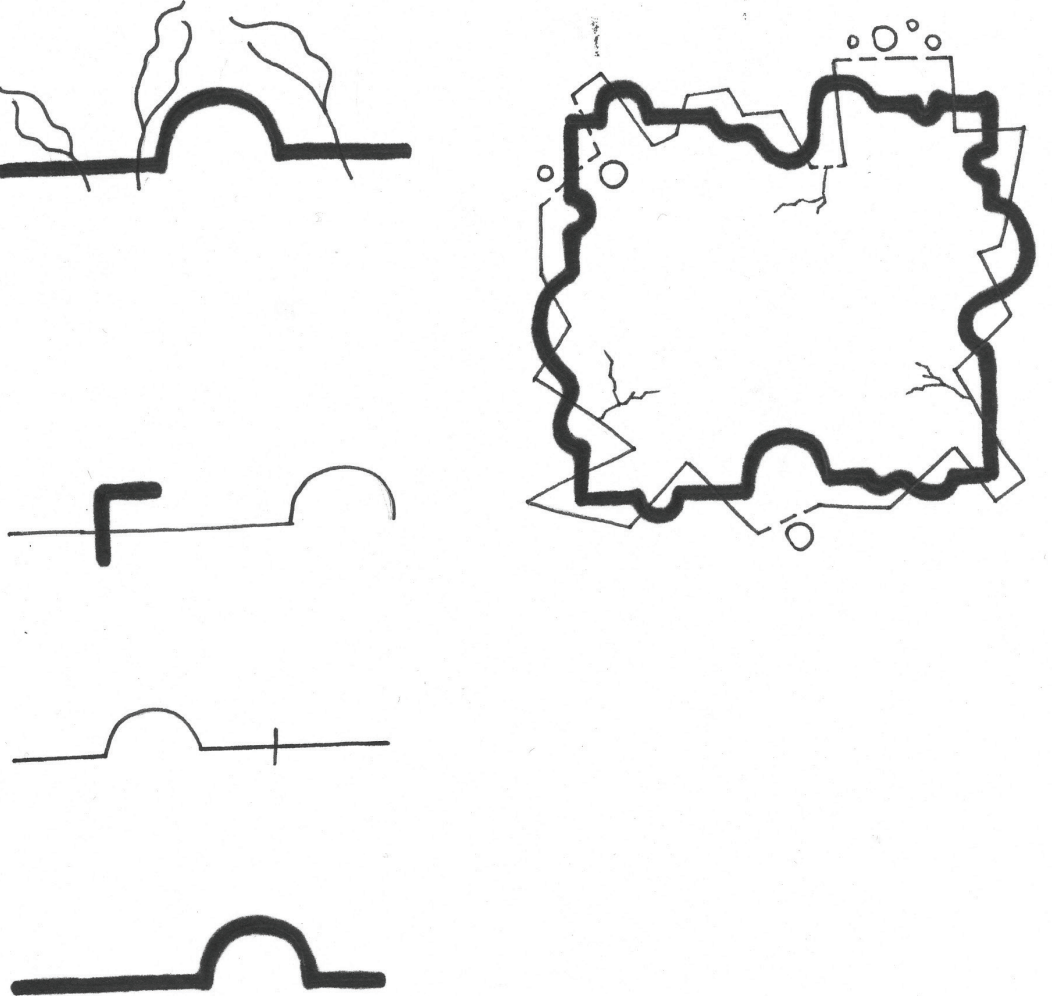

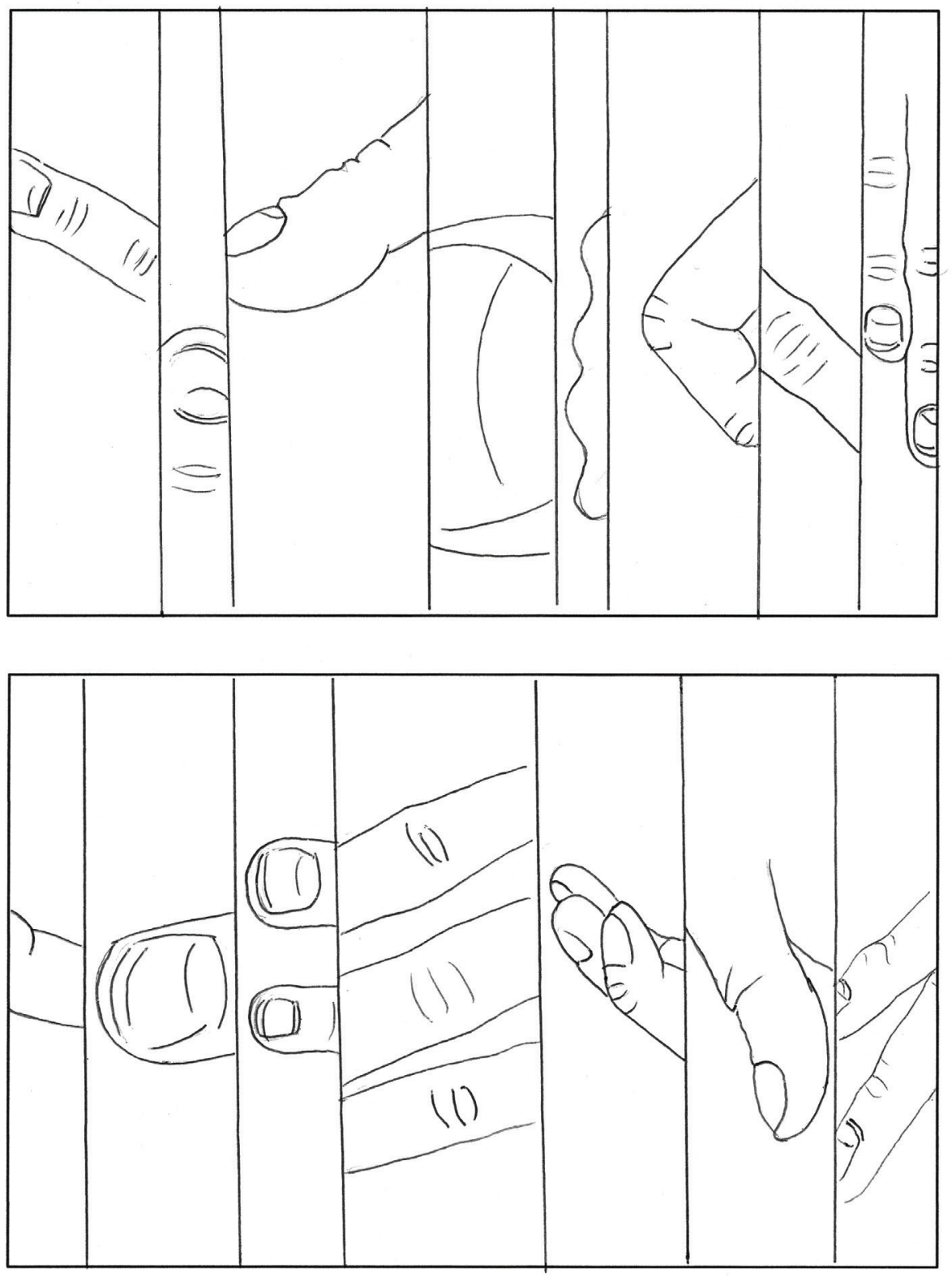

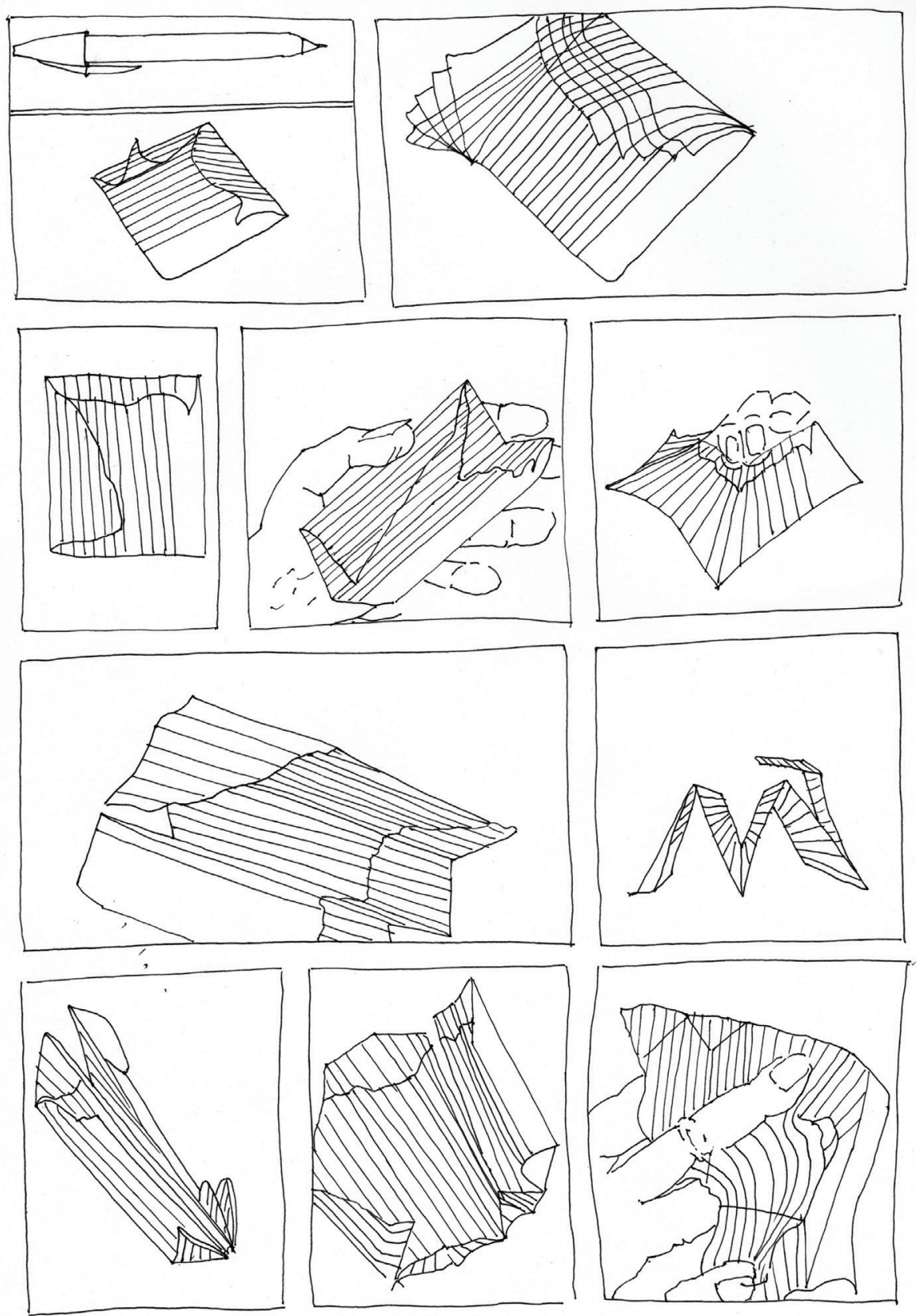

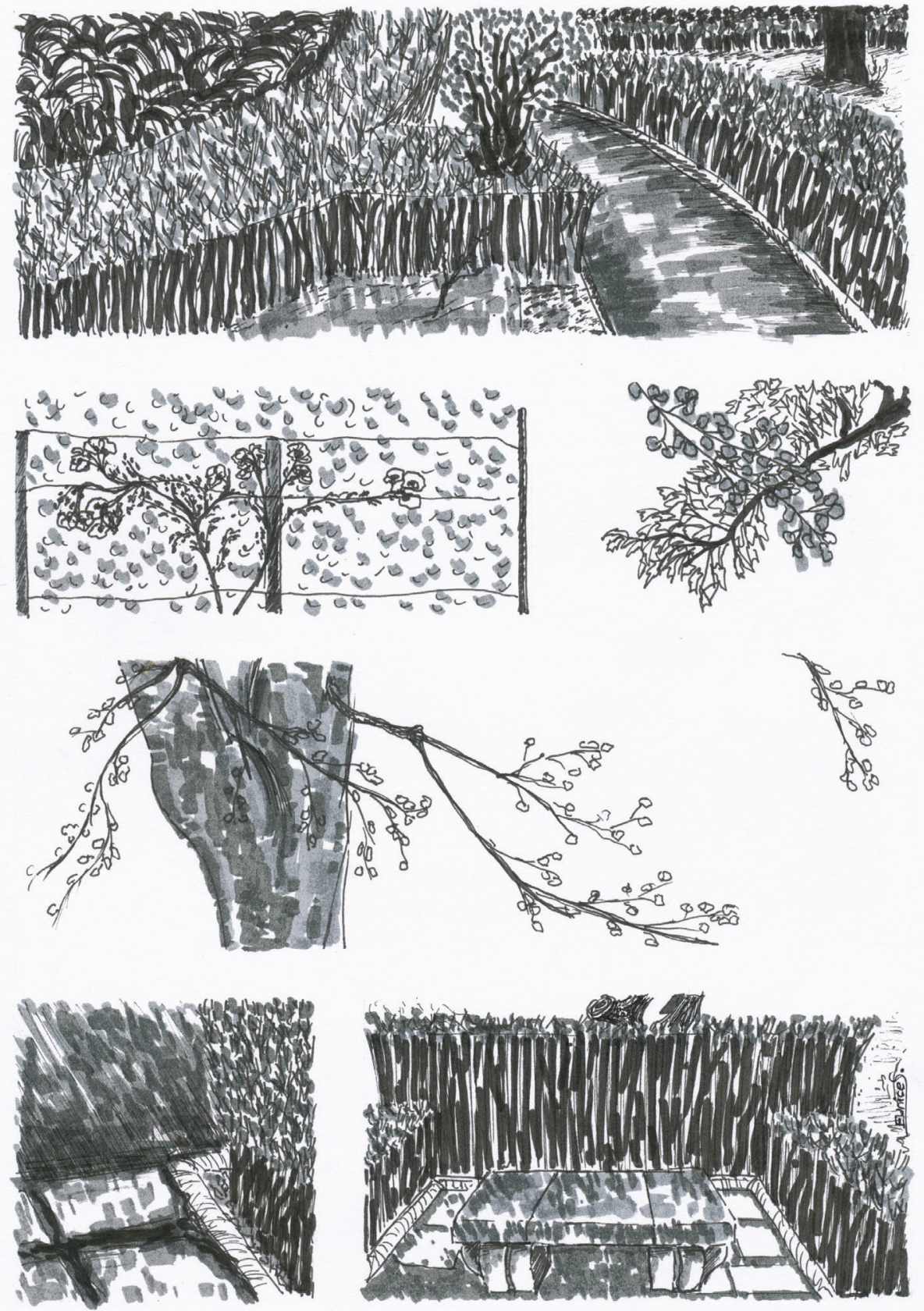

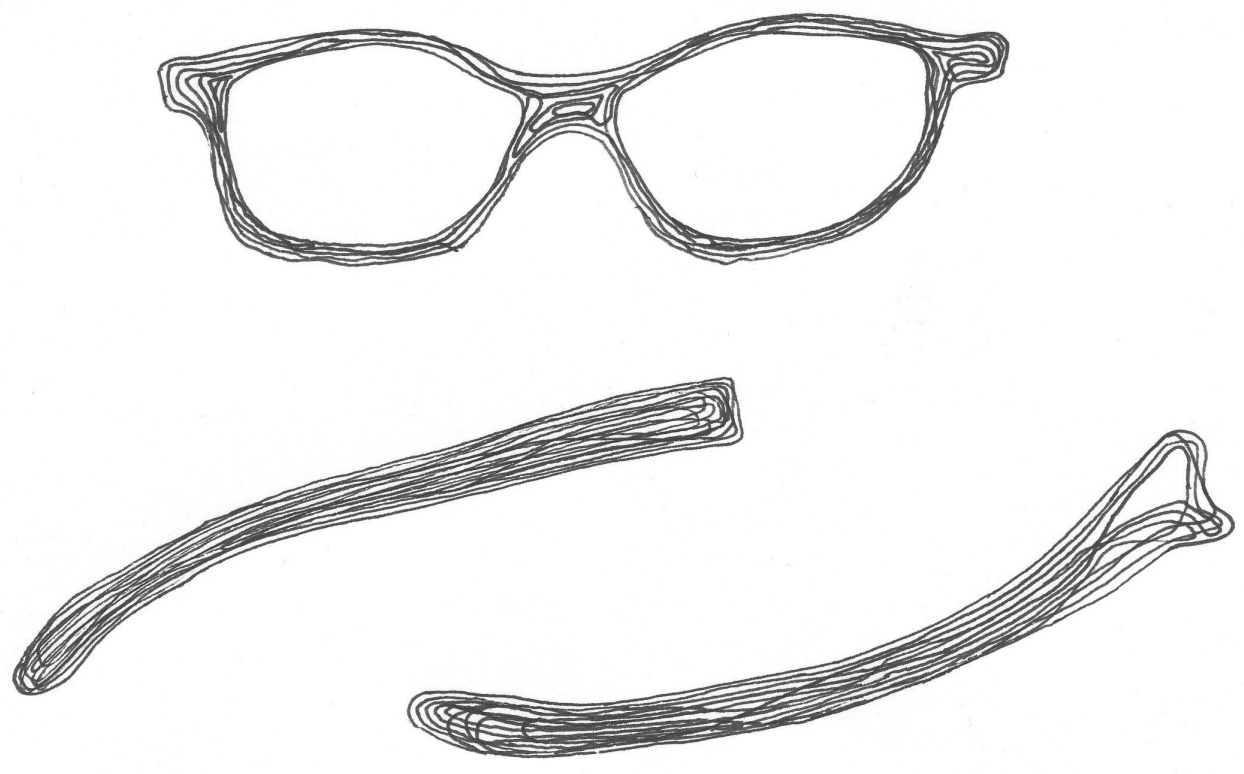

54
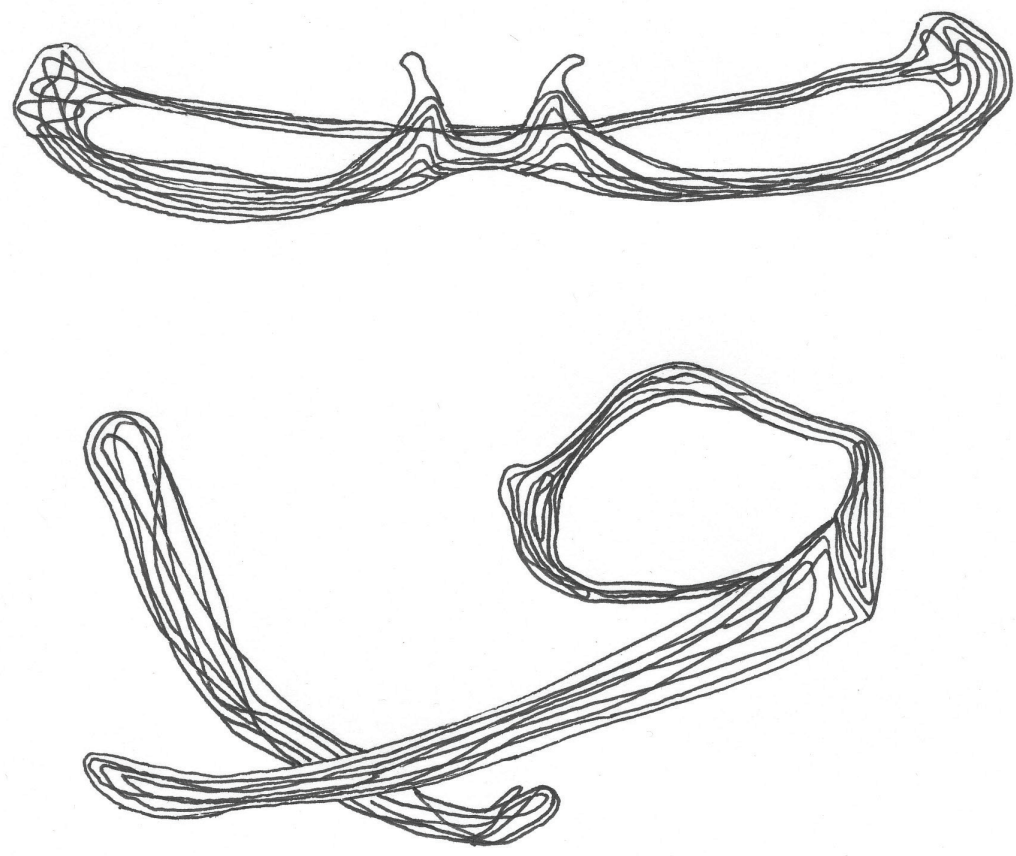

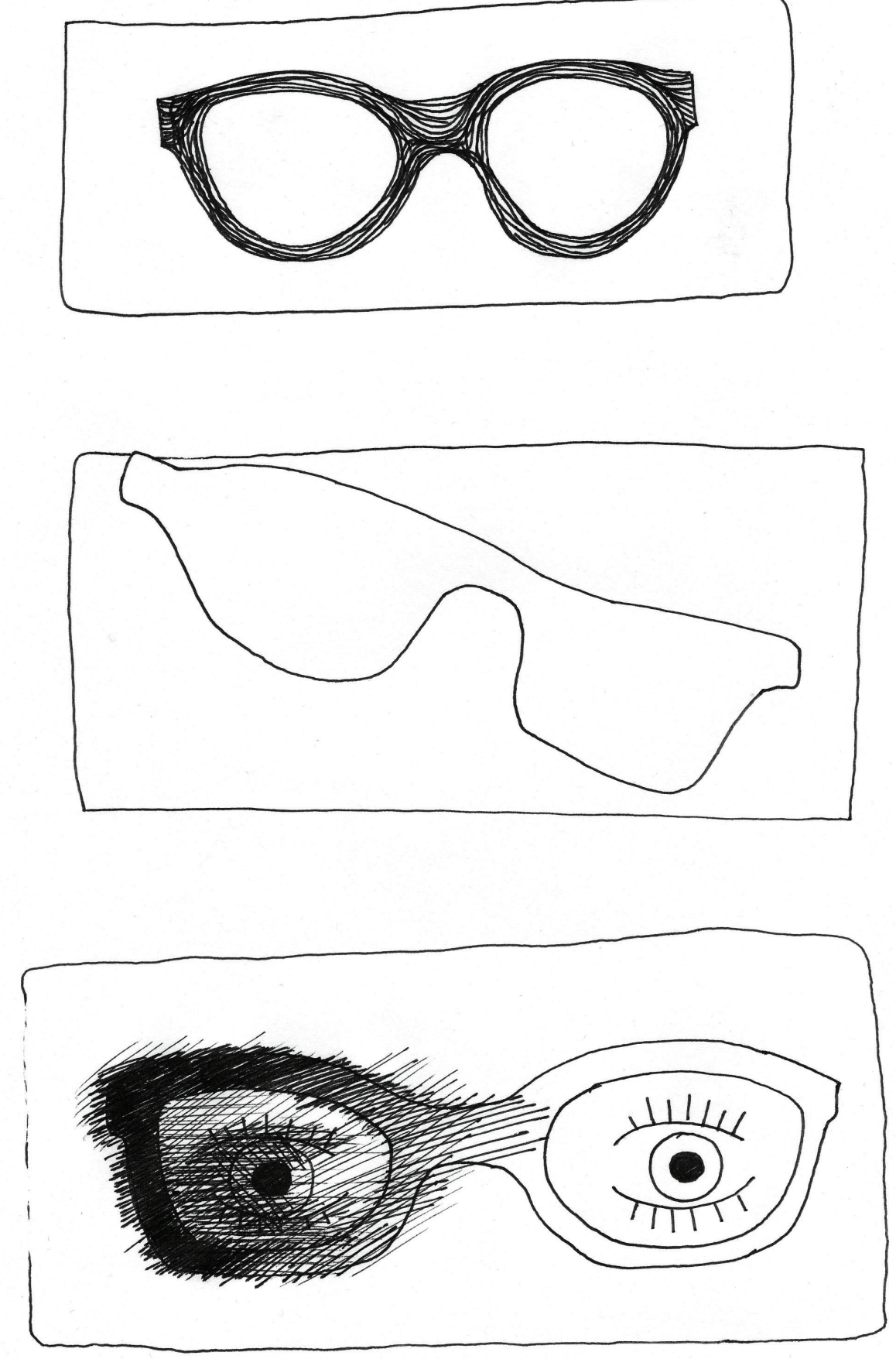

Anabela Diogo 

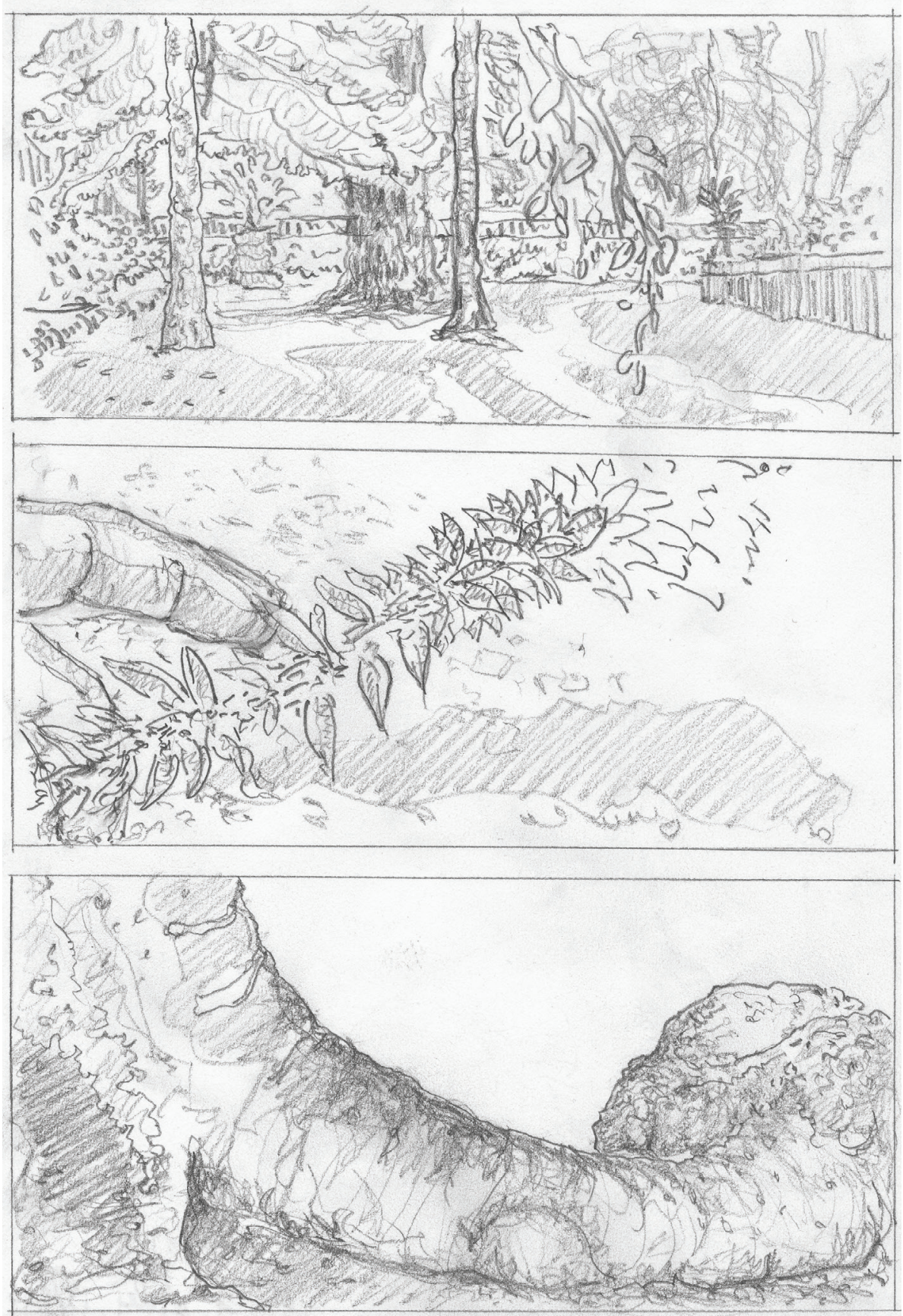

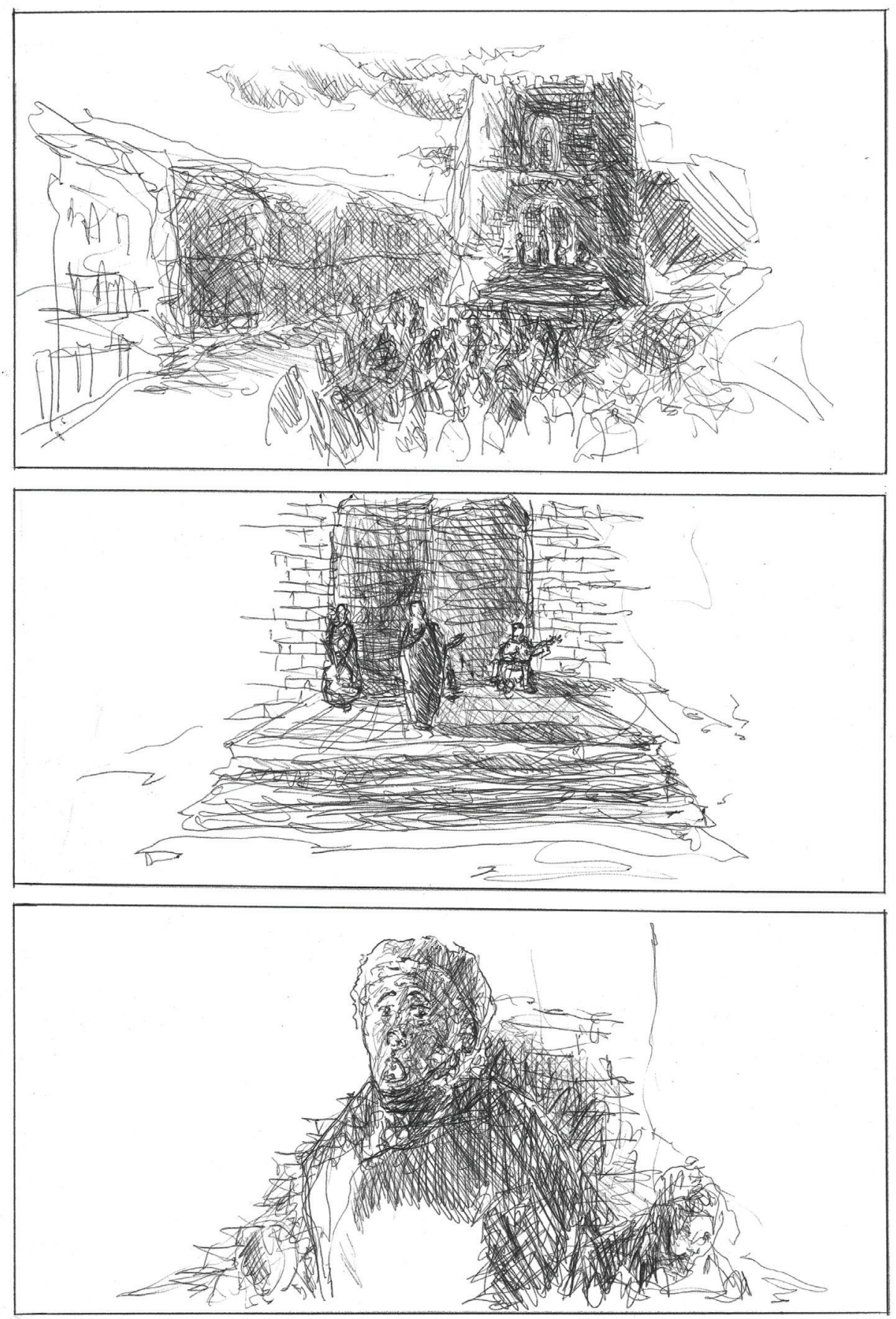

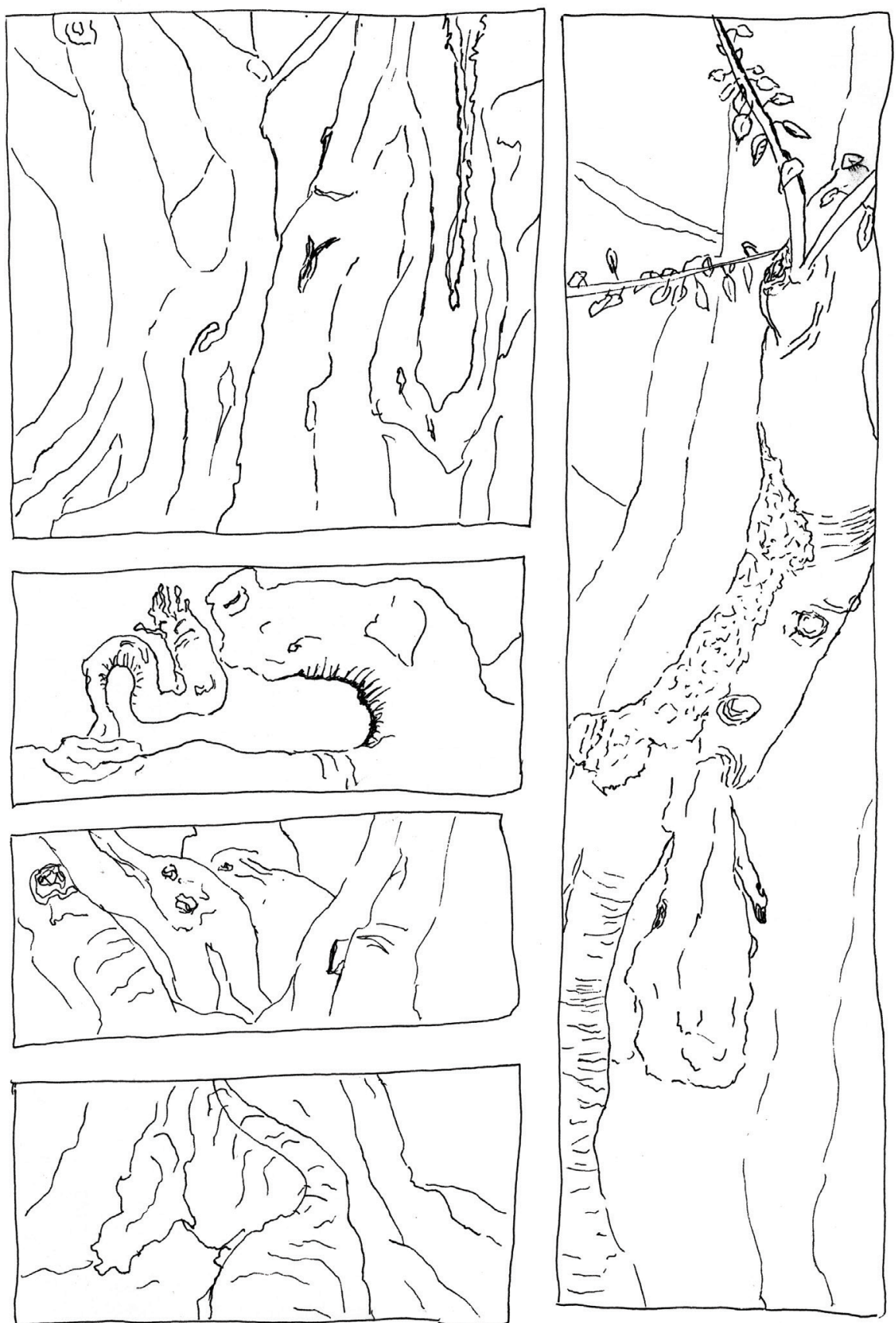


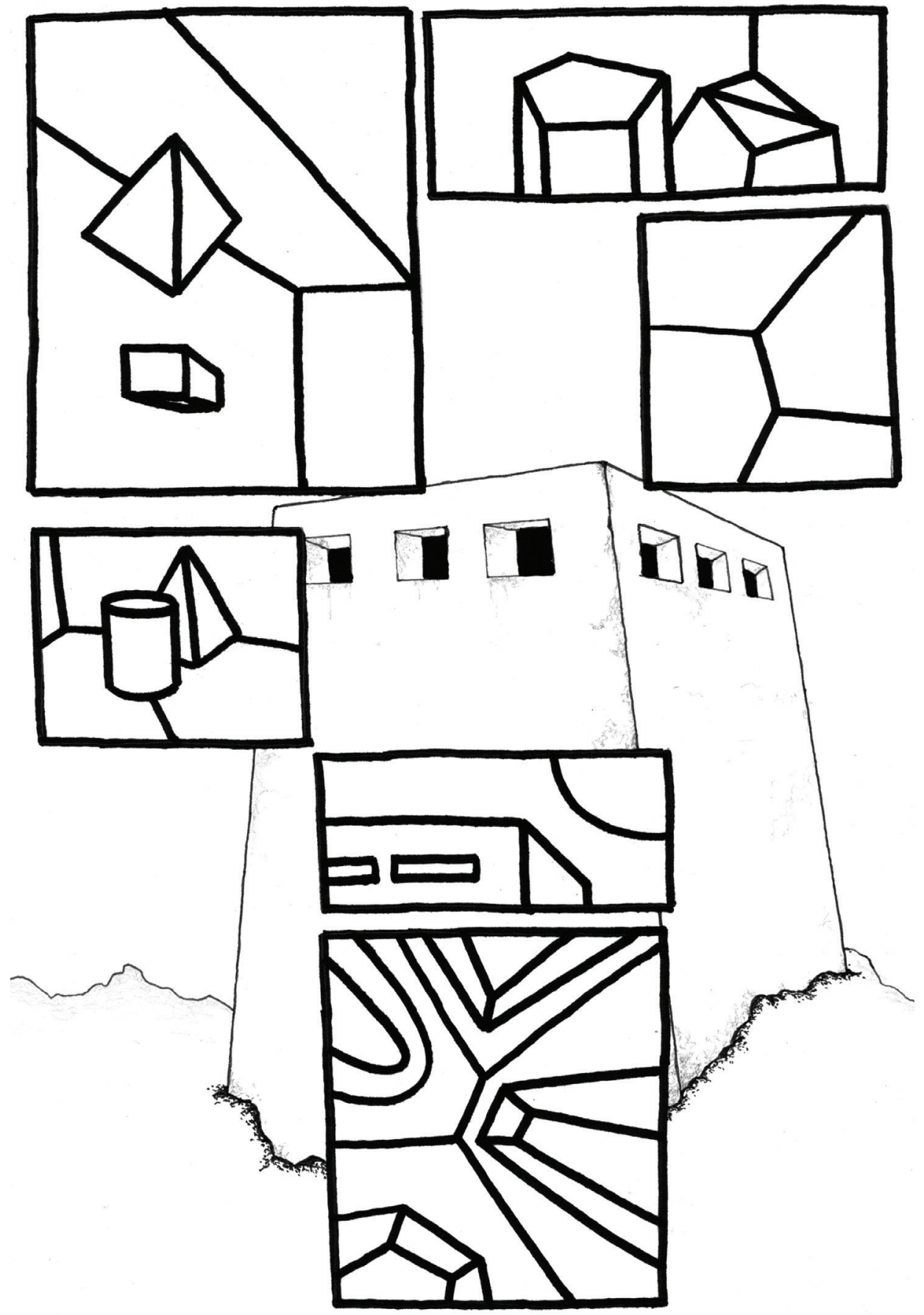


(Página deixada propositadamente em branco) 


\section{DEPURAÇÃO E METAMORFOSE FORMAL}

Estes exercícios têm como ponto de partida representaçóes de plantas que, após sucessivas transformaçóes, se vão afastando de uma vocação figurativa para enfatizar qualidades plásticas.

Assim, os procesos de tranformação são ditados pelas potencialidades formais, pela capacidade de formas gerarem formas, assim como pelas possibilidades dos jogos compositivos.

A qualidade gráfica dos gestos da represntação dá lugar á construção de formas onde a gestualidade se apaga mas das quais a gestualidade foi o primeiro dado, o início de toda a transformação. Essa gestualidade inicial era ditada pela procura de representação. Os gestos que lhe seguiram nas fases subsequentes conduziram o processo transformador,

Os resultados finais que aqui são reproduzidos são produto de todo este processo gestual. O facto de serem finalizados em recortes de cartolina clarifica e sedimenta a sua condição de composição final, deixando para trás as marcas da pesquisa gráfica que o gerou. 
(Página deixada propositadamente em branco) 

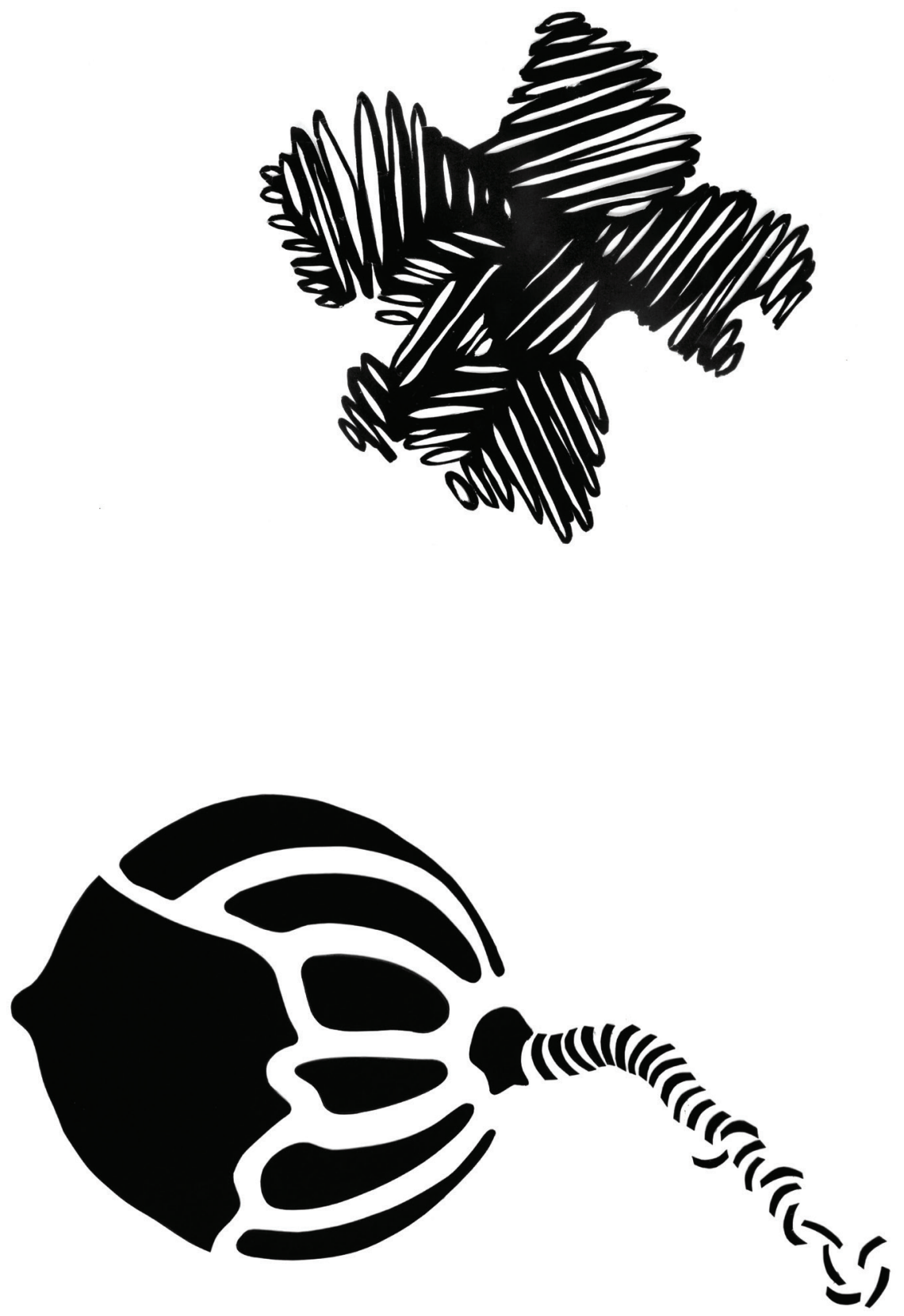

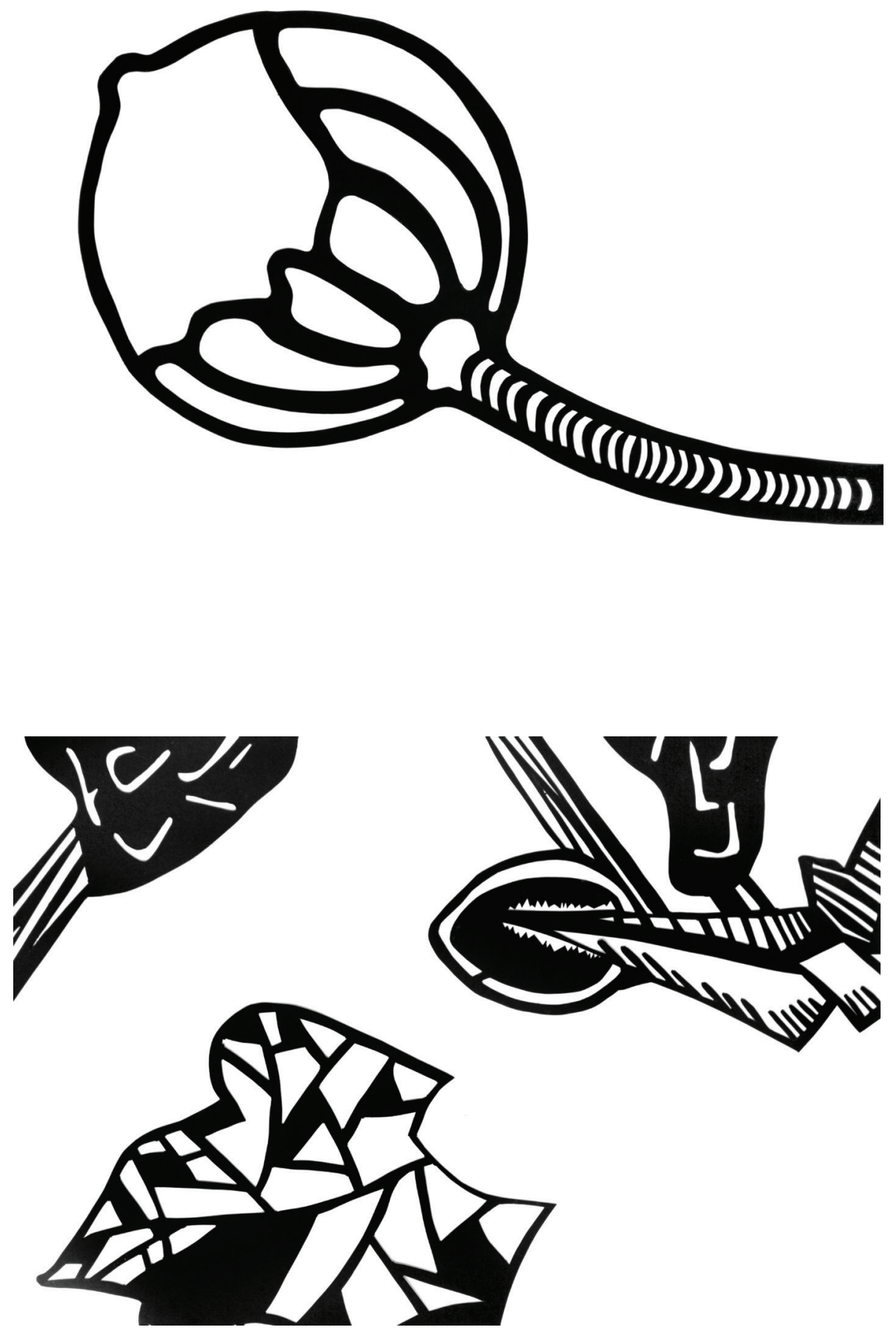

Pedro Teixeira, Patrícia Sobreira 

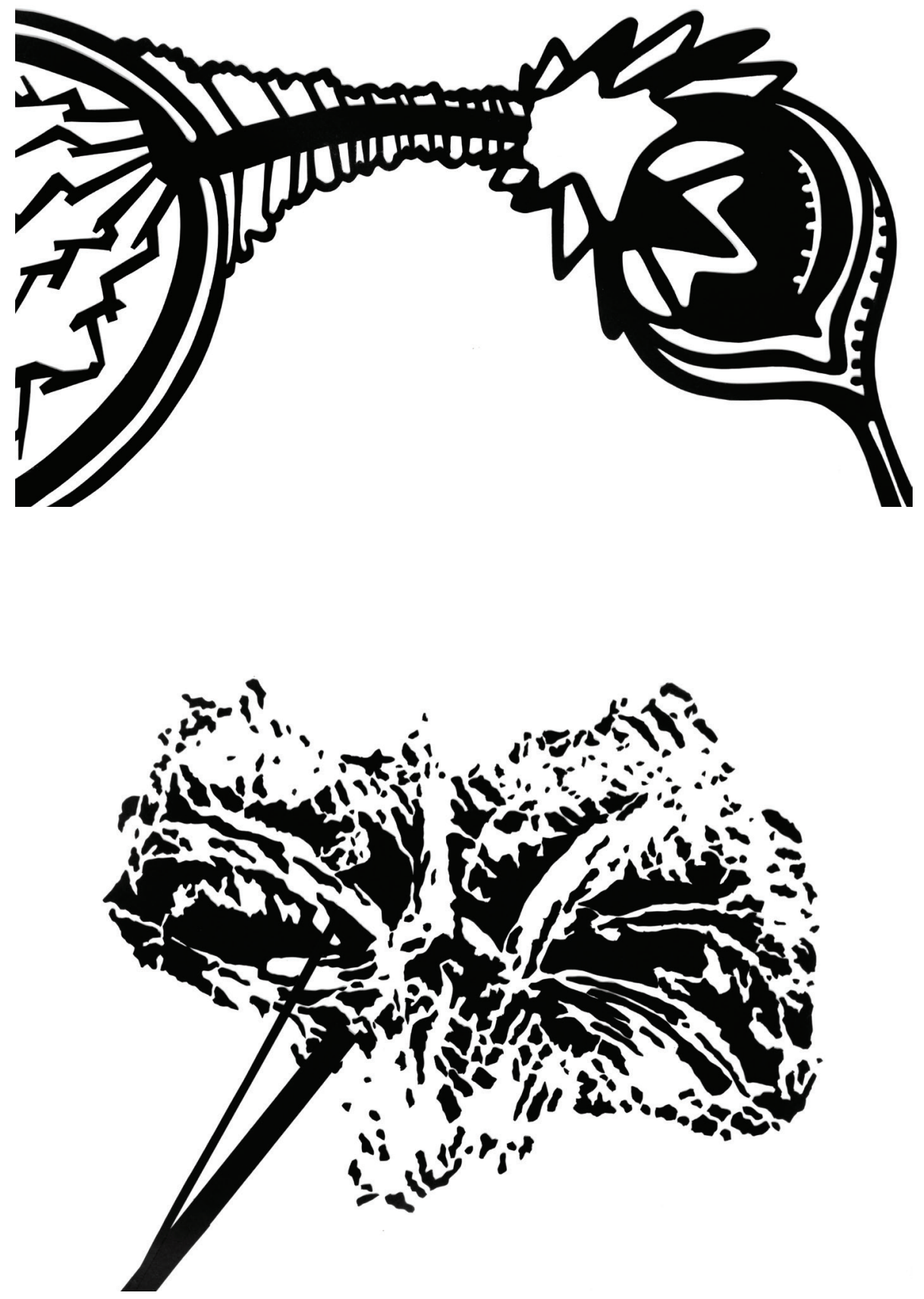

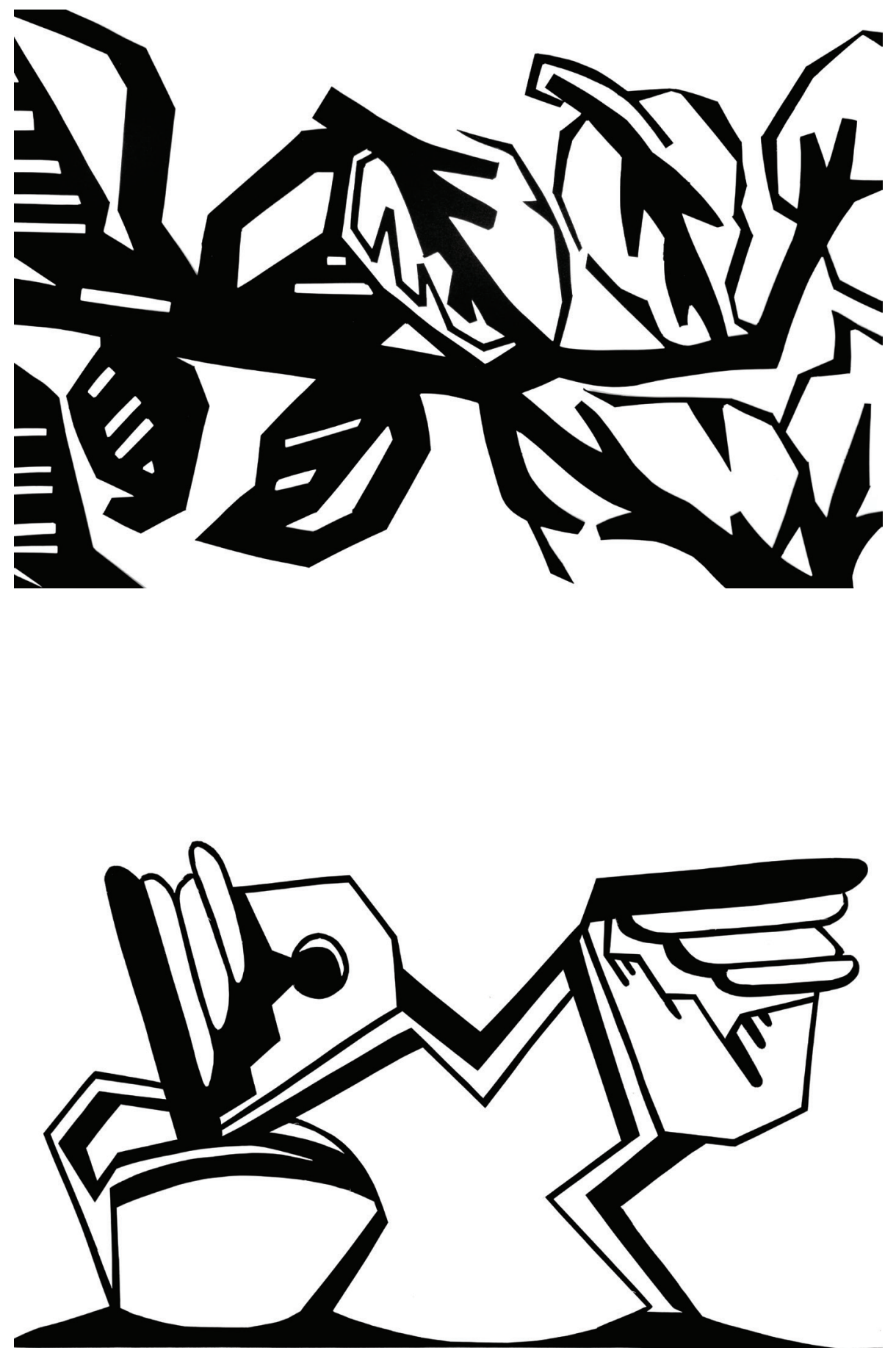

Nide Santos 


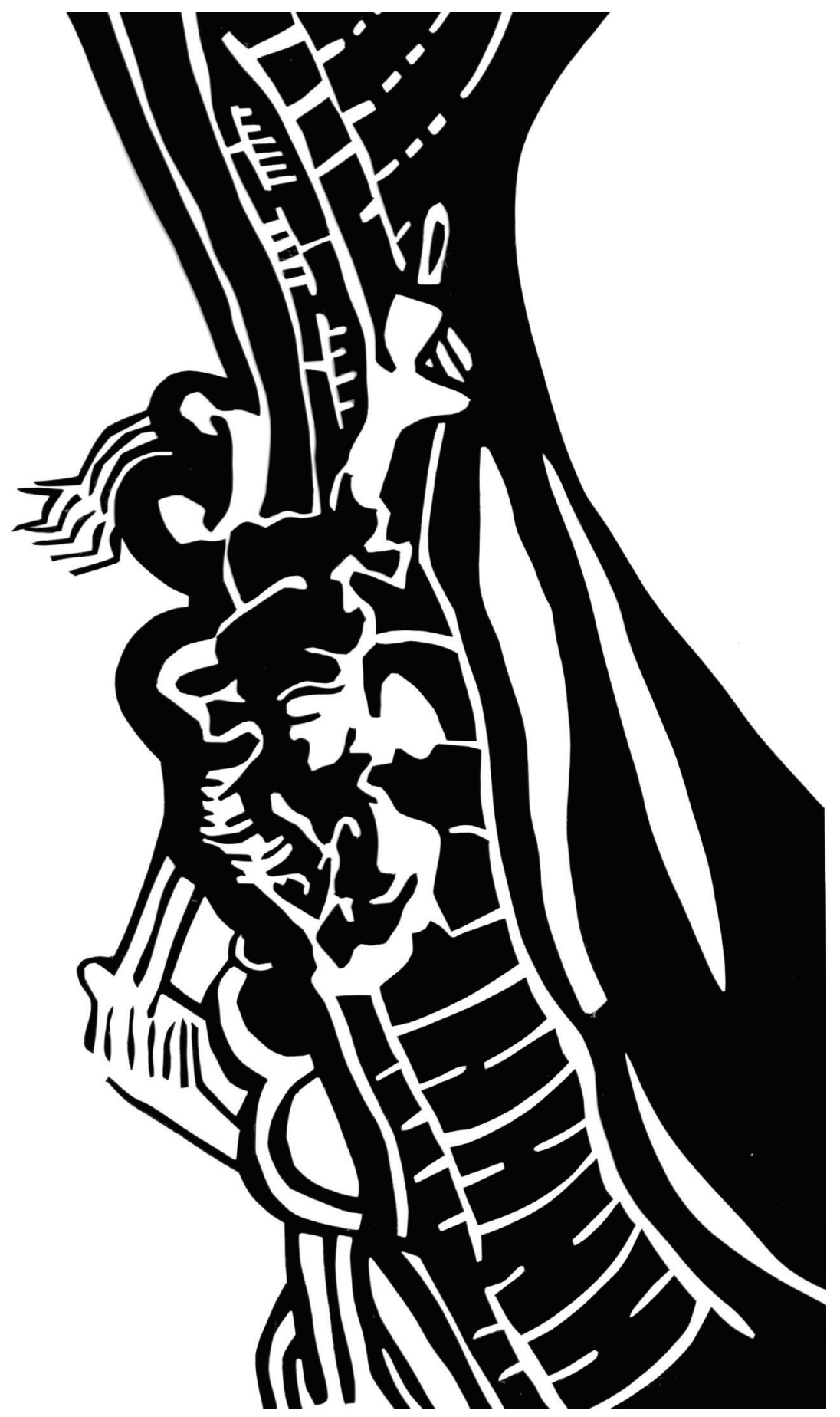




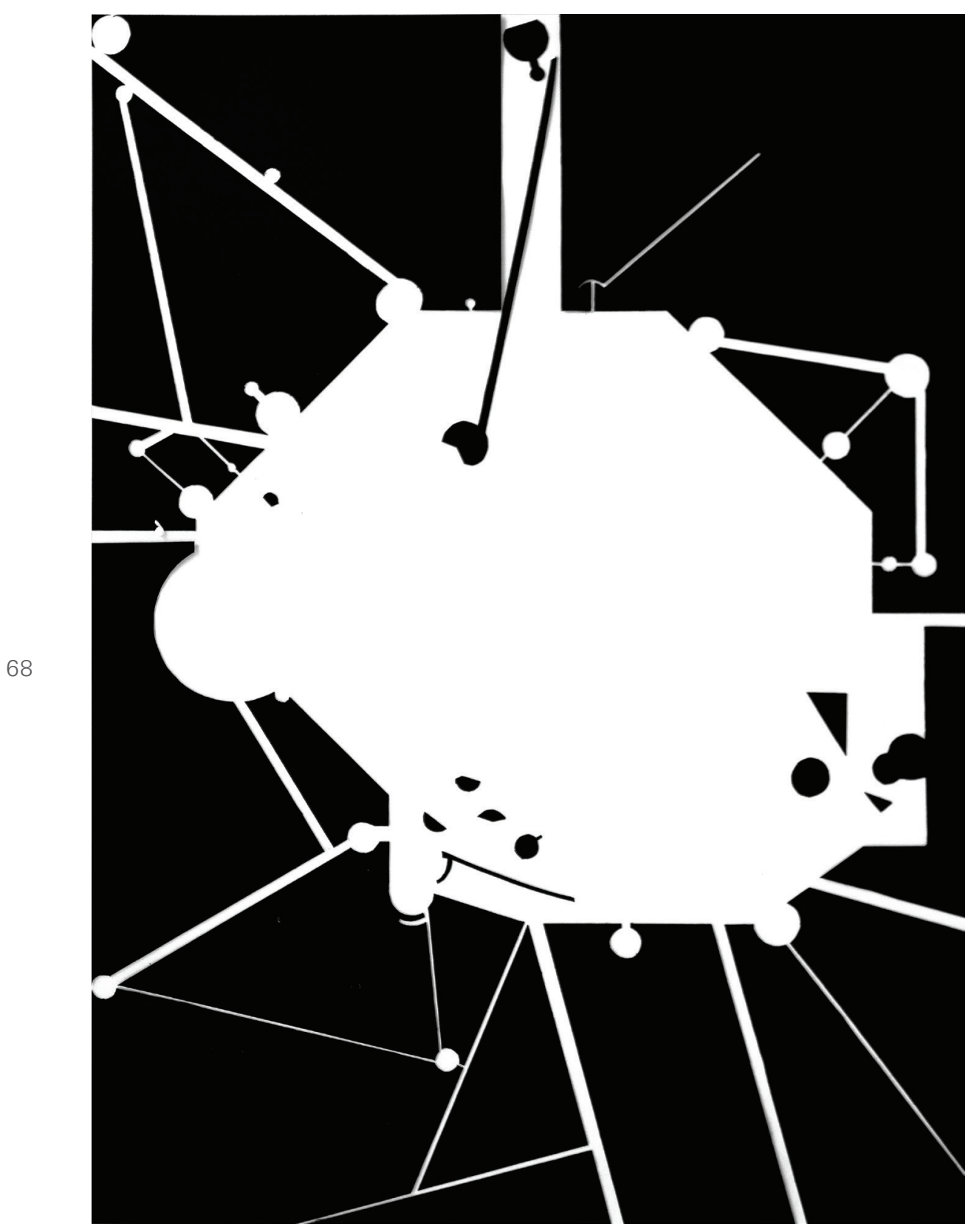




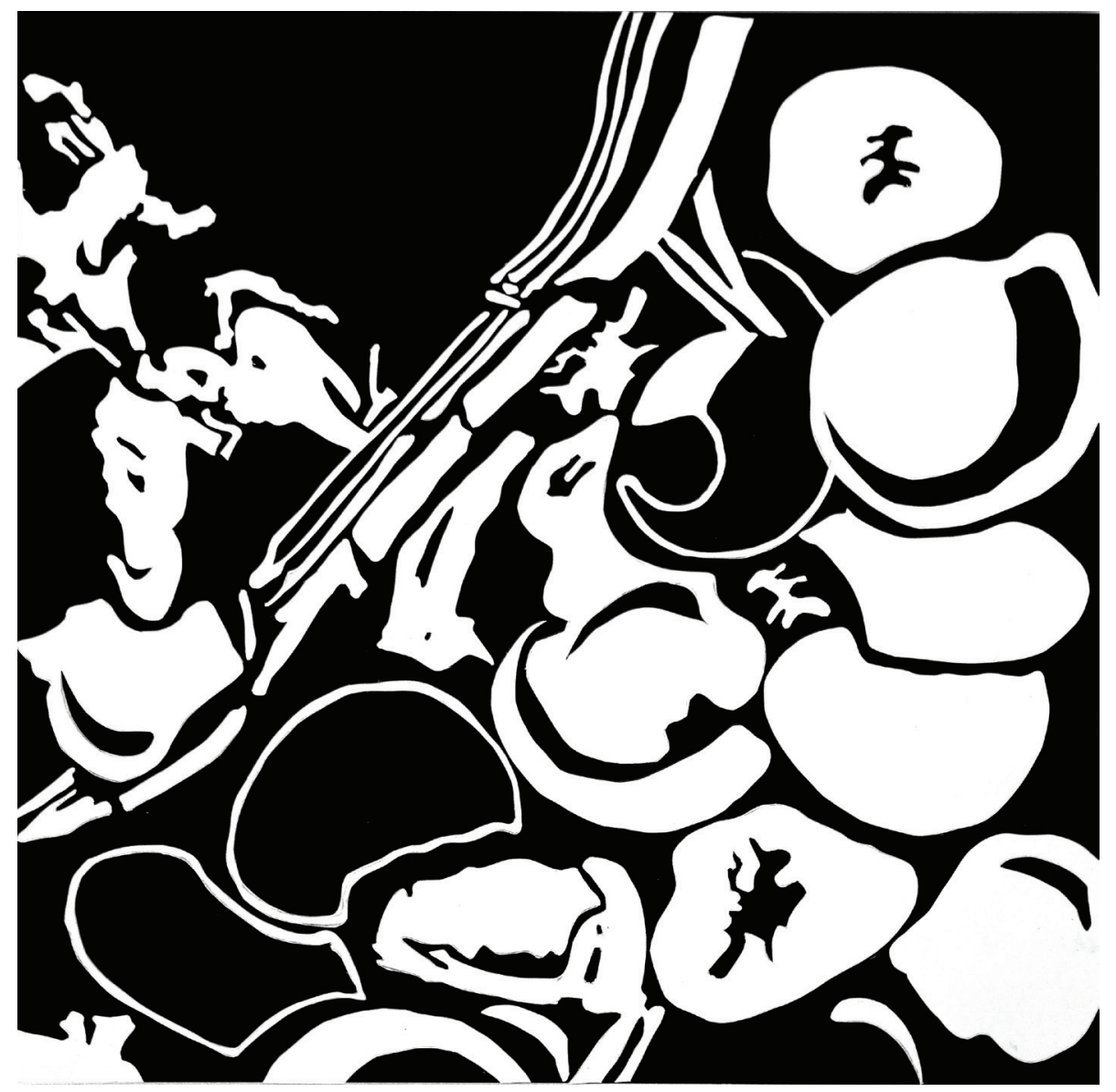



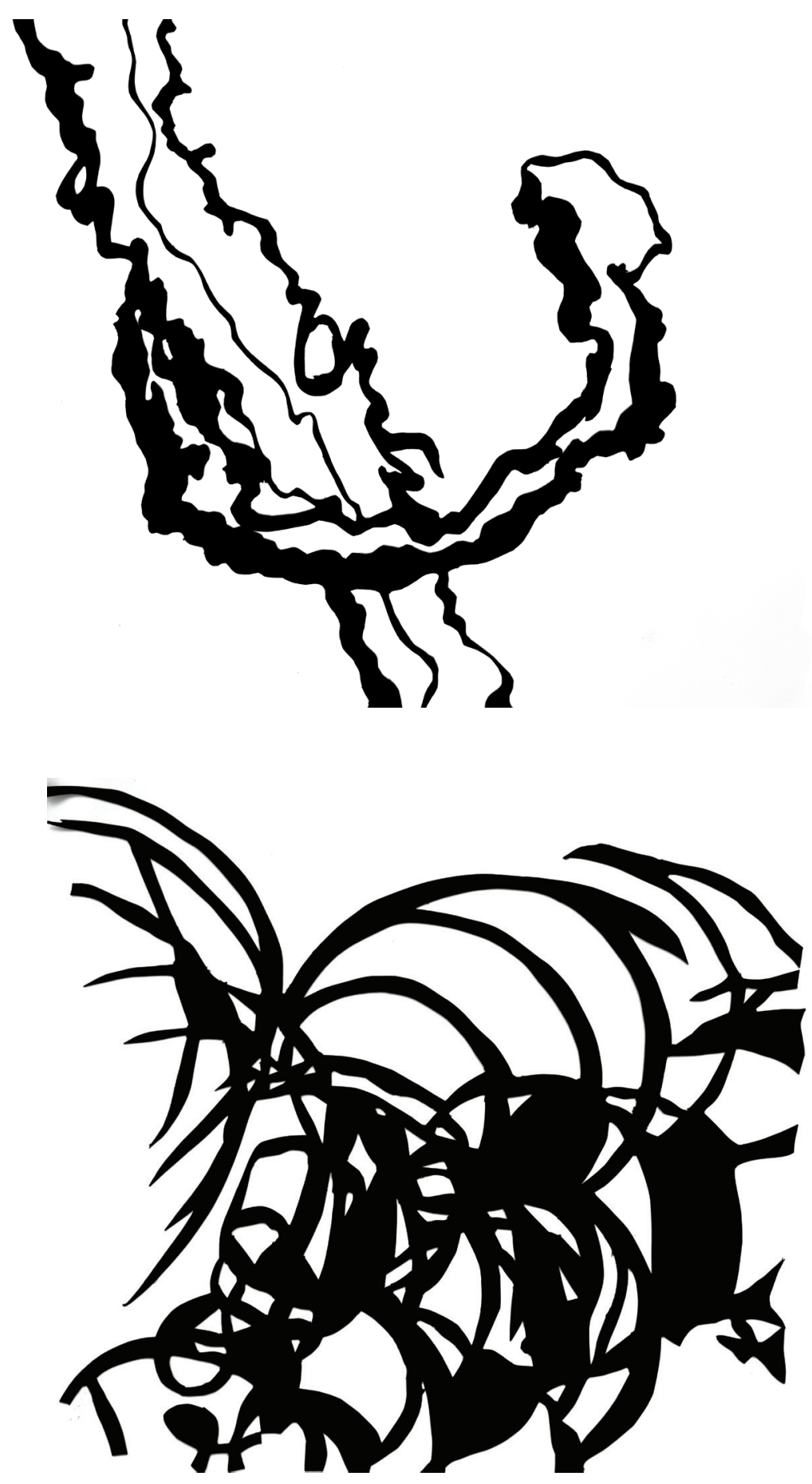


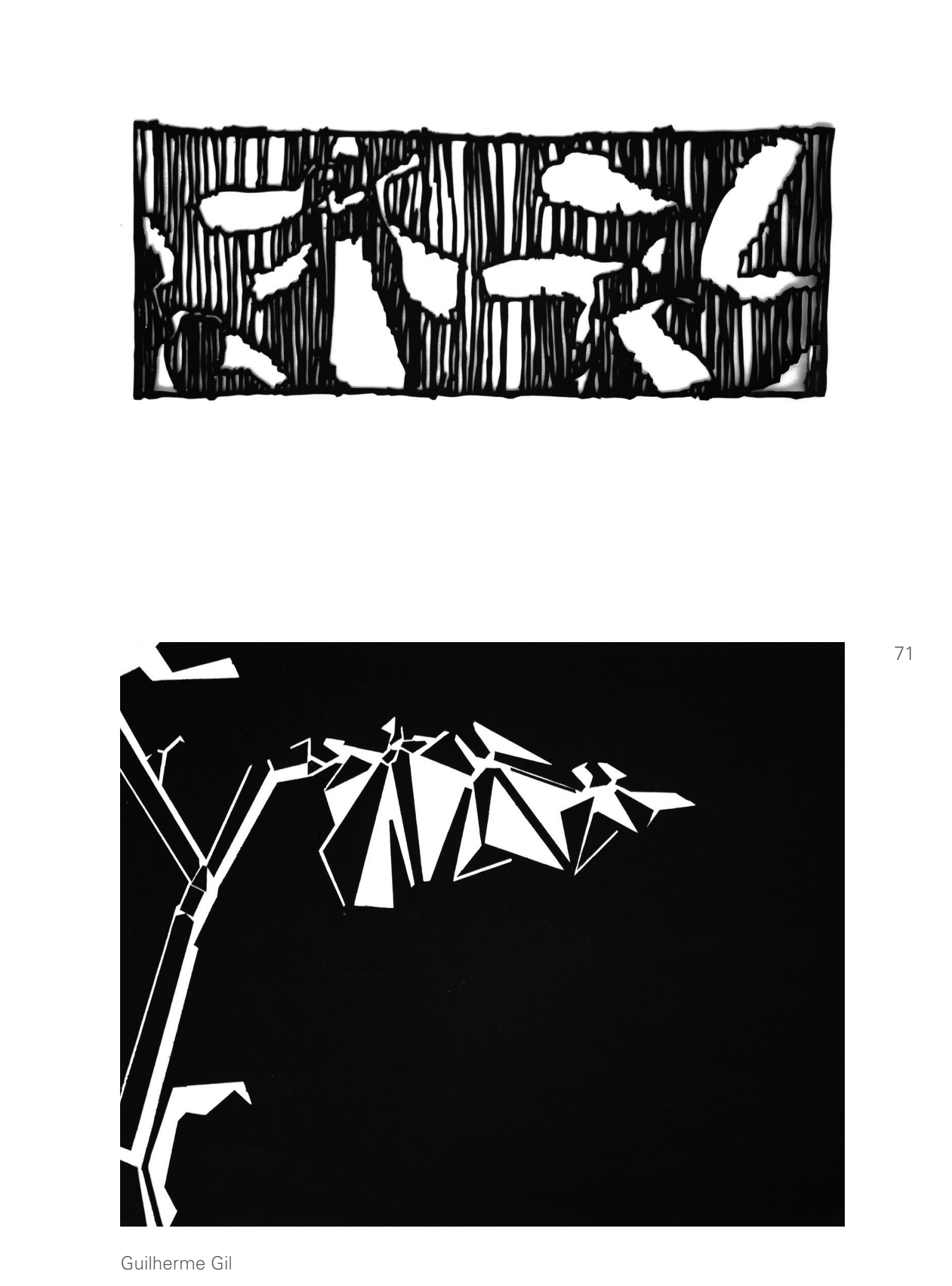




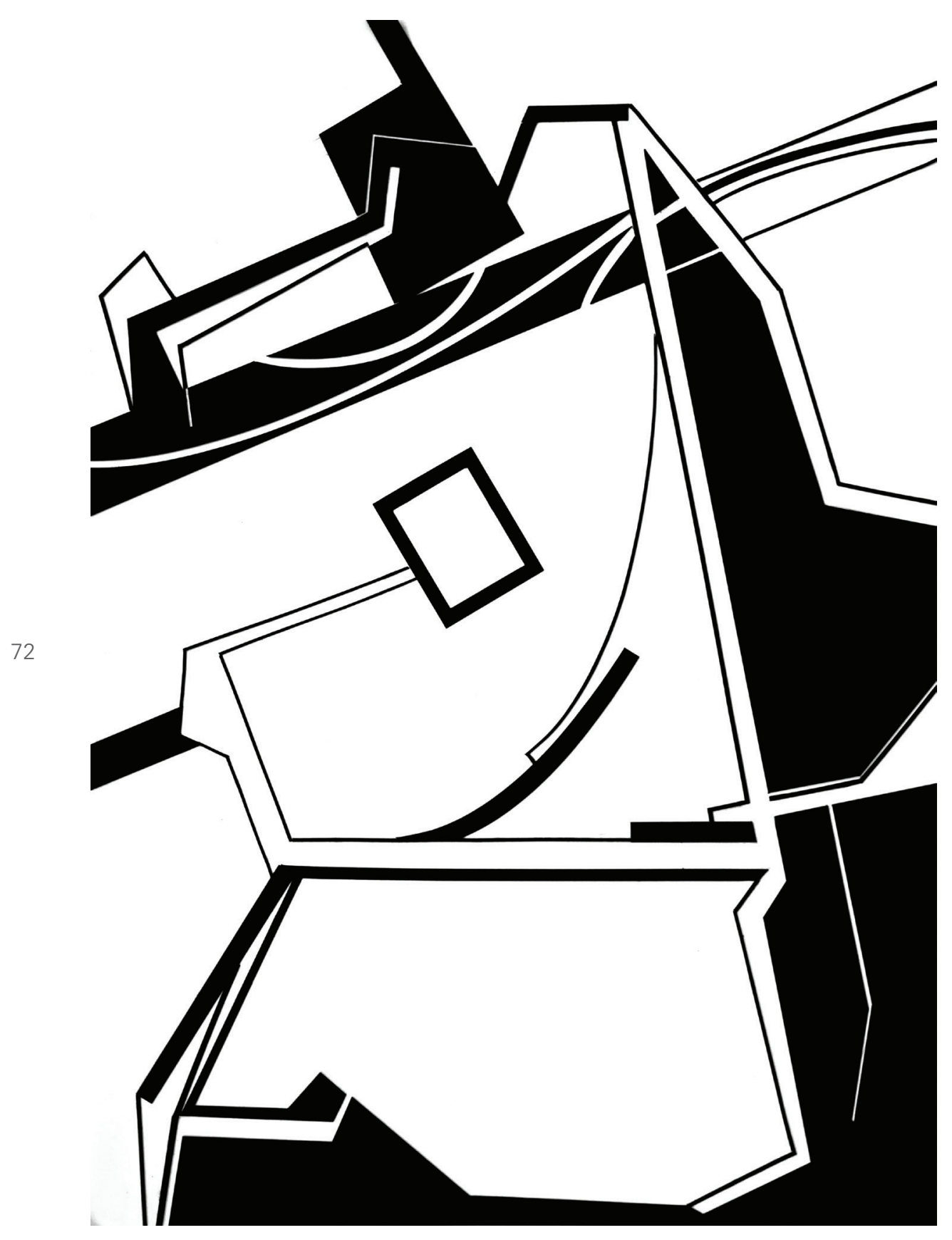

Tiago Santana 


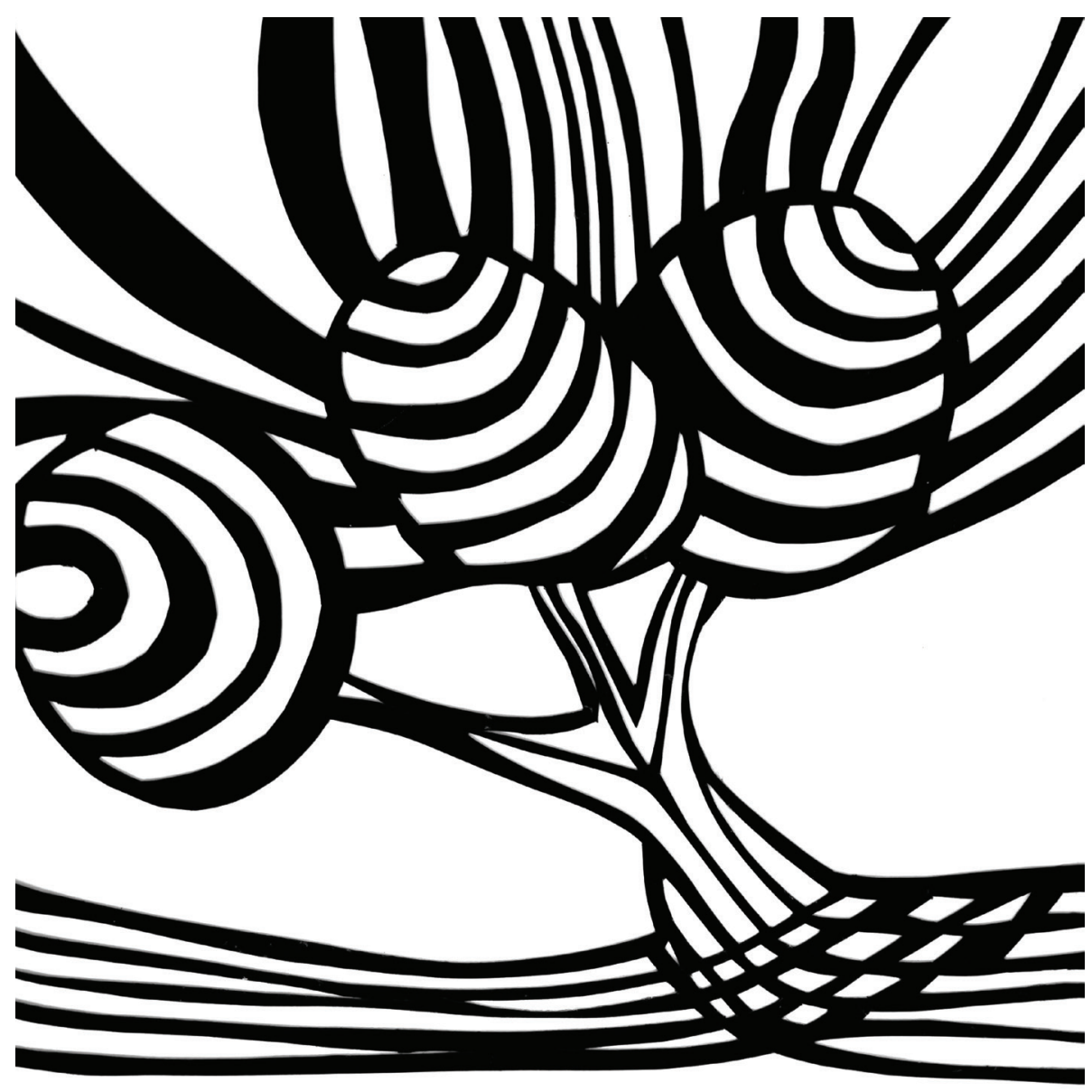




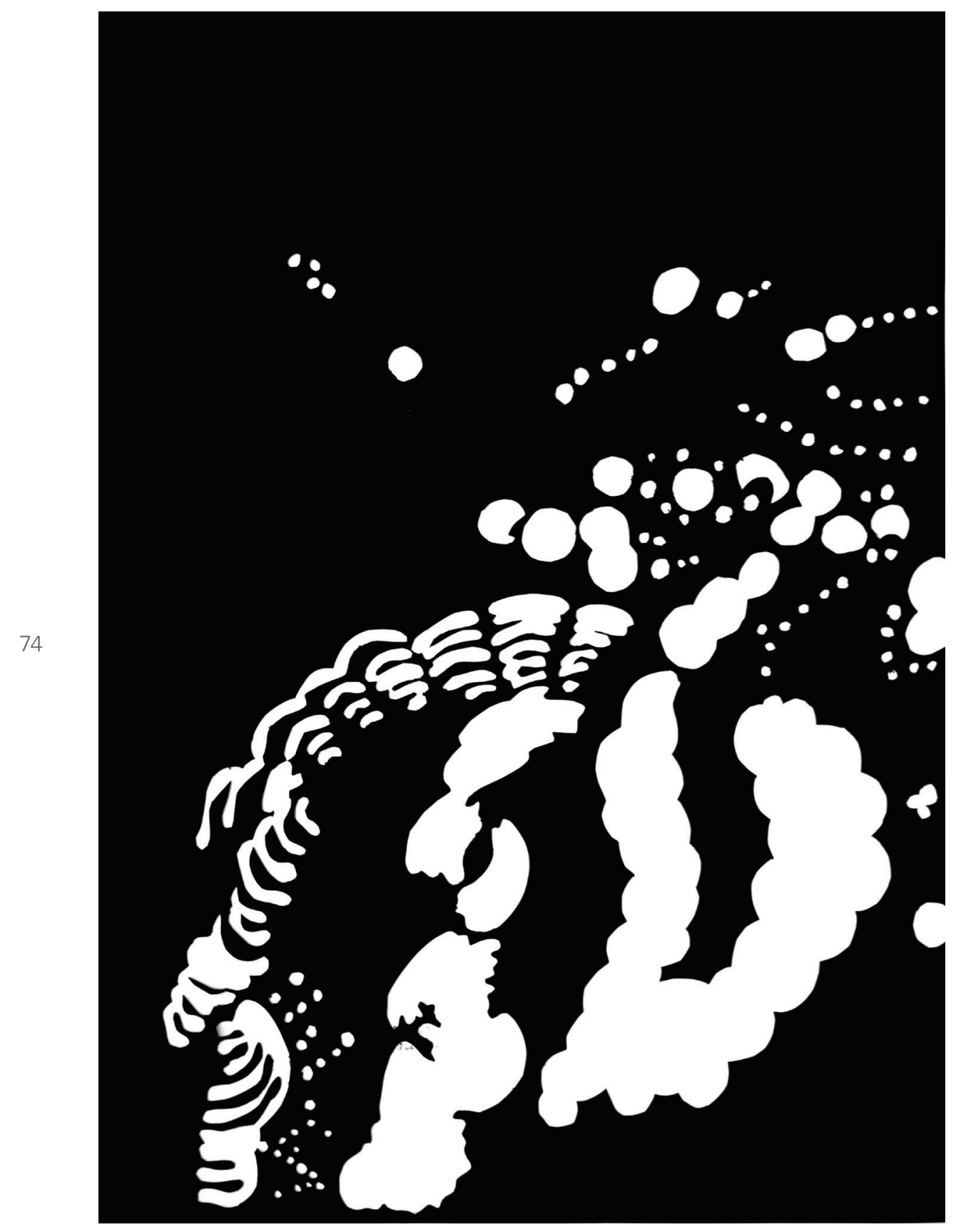



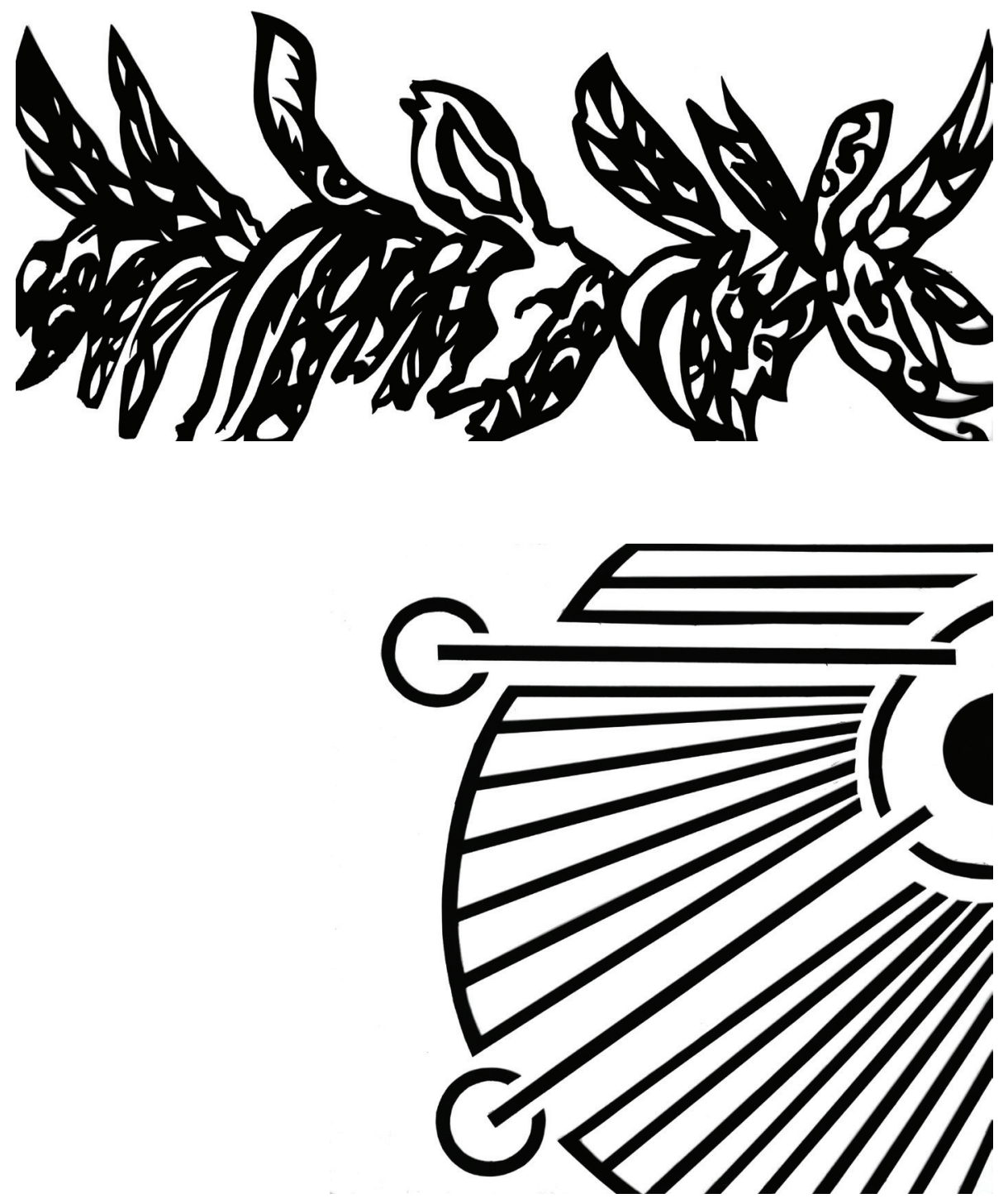


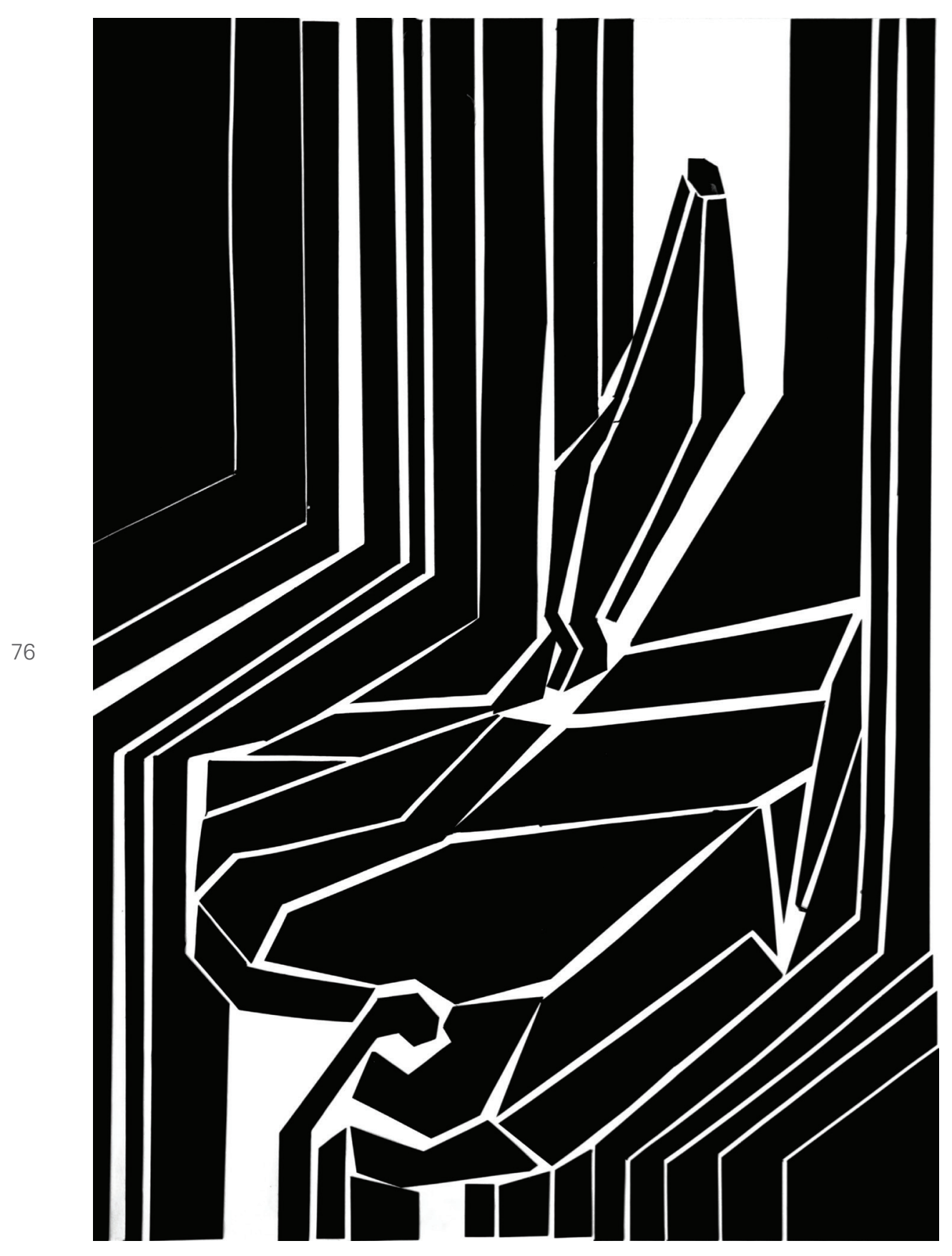



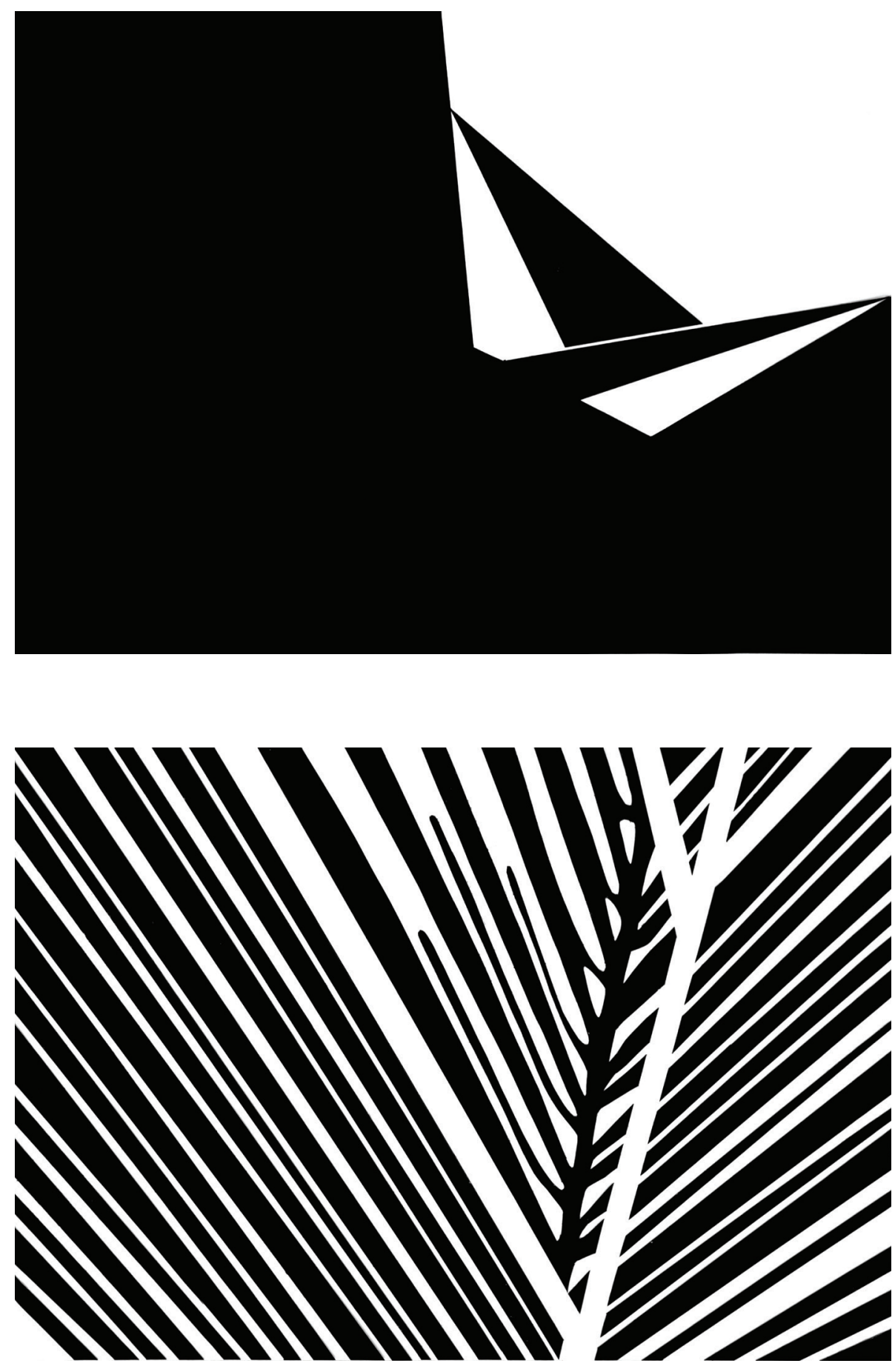

Luís Sobral, Vasco Silva 


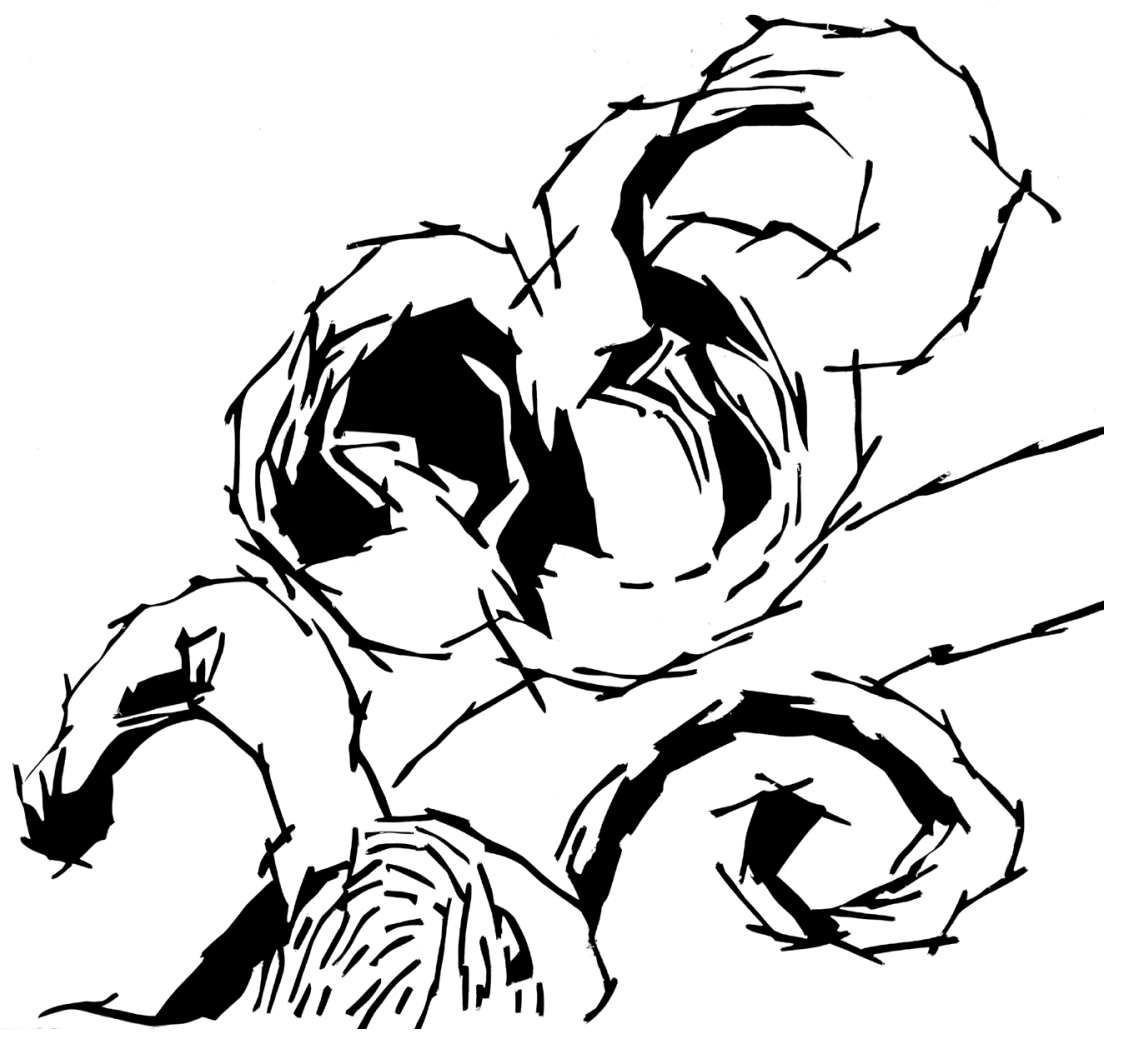



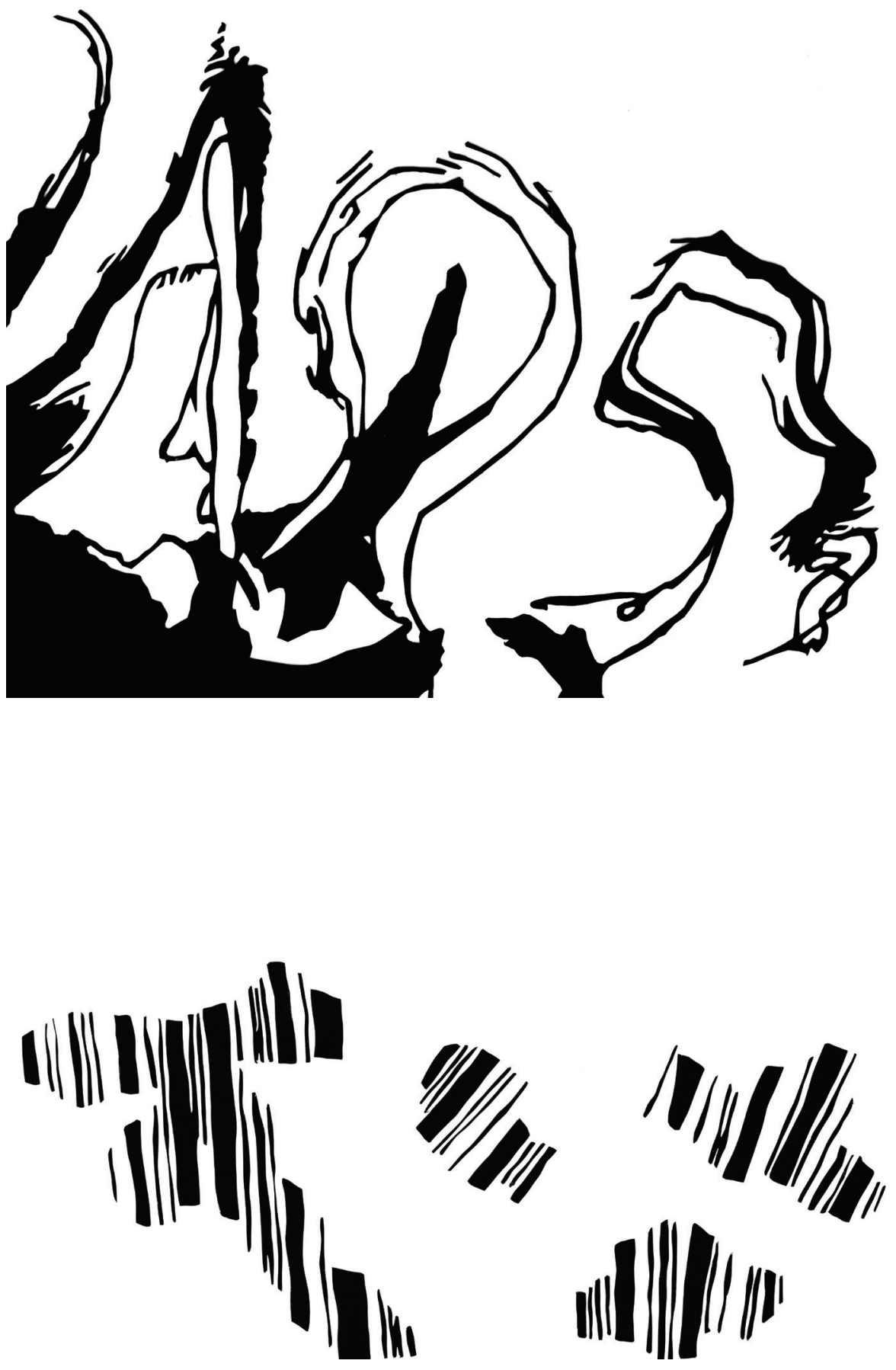


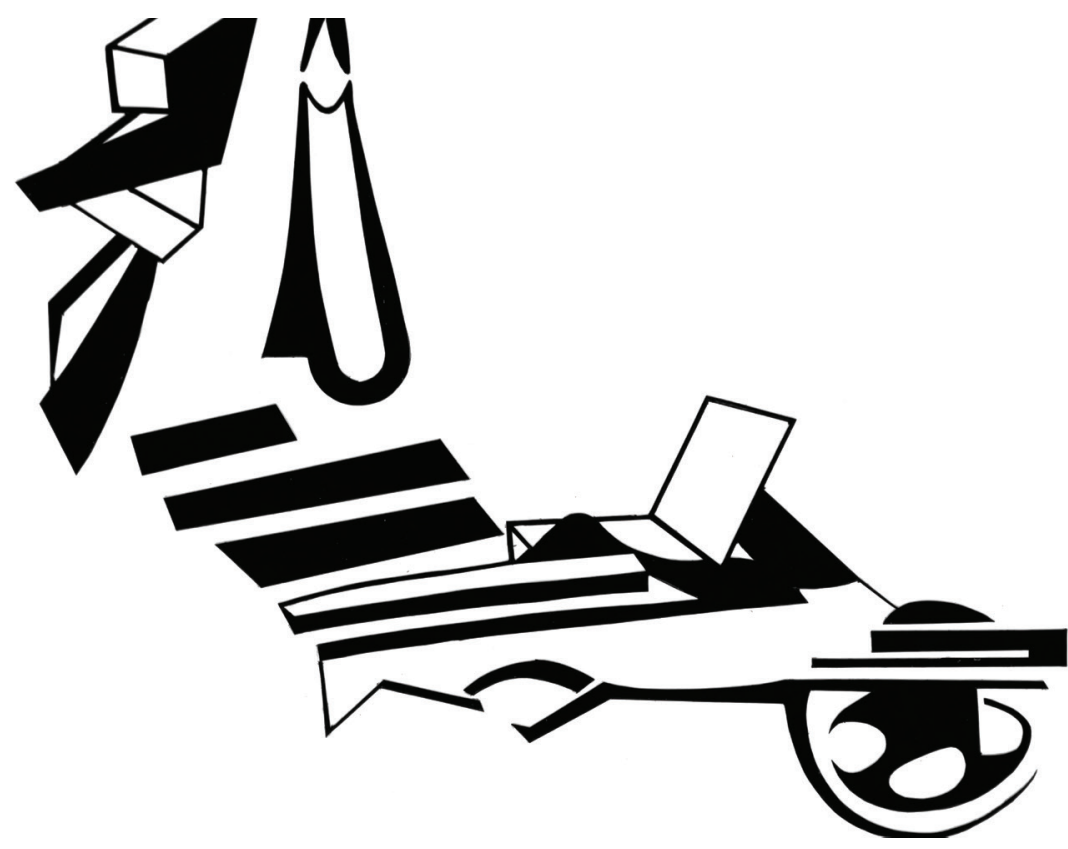

80
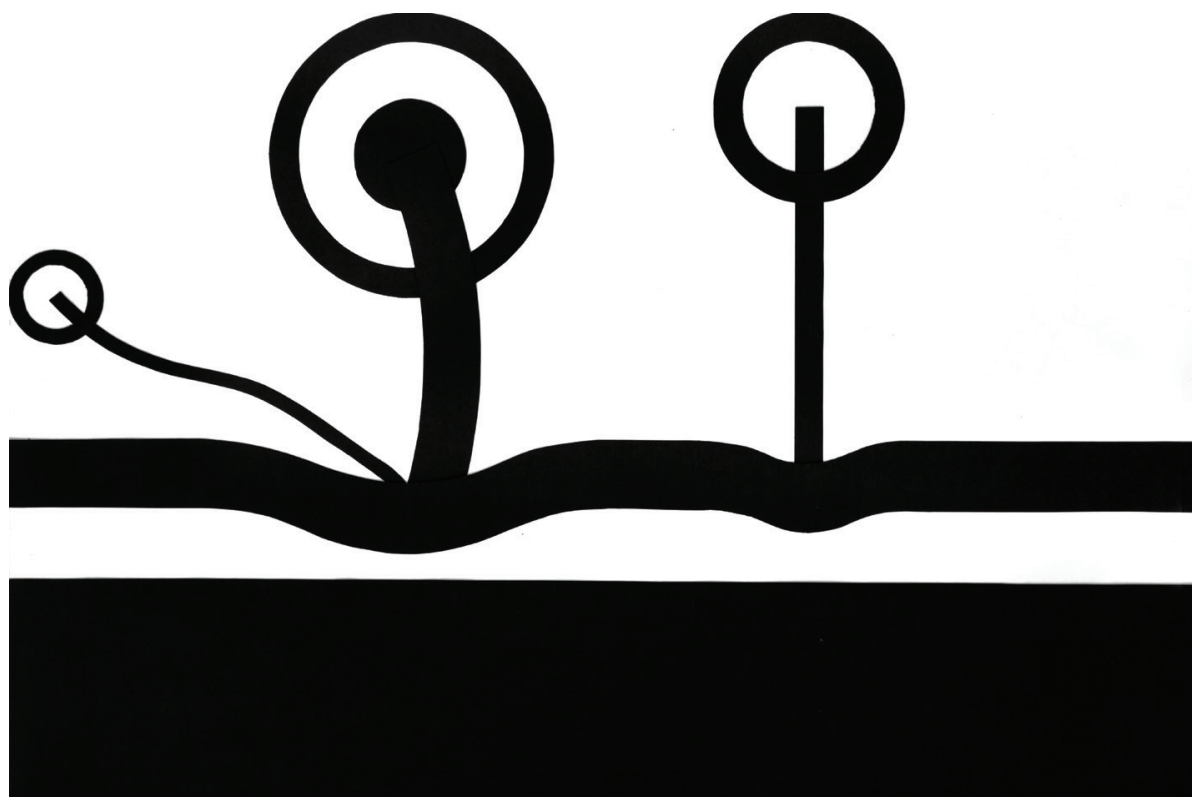

Filipe Coelho, Daniel Oliveira 


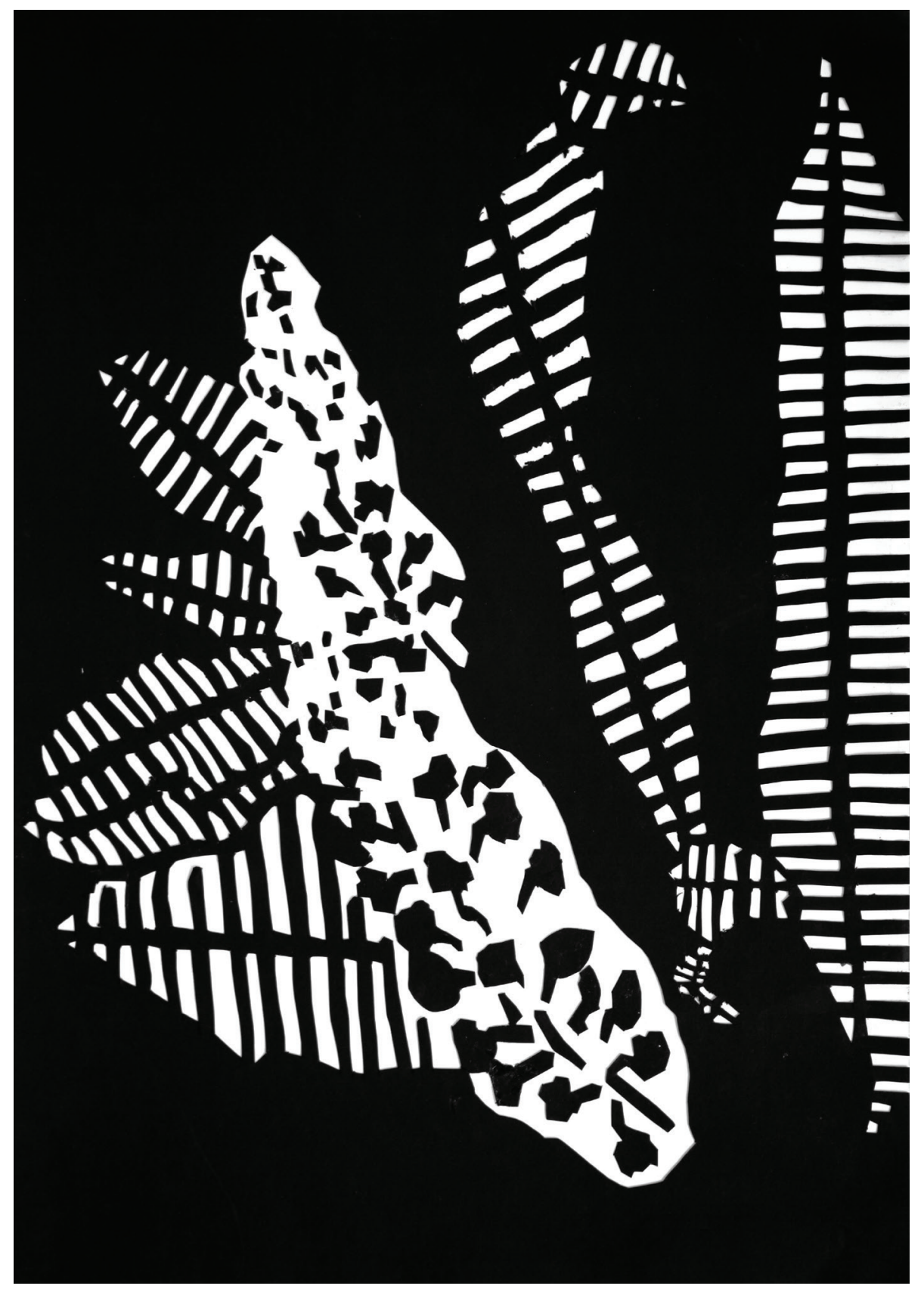


(Página deixada propositadamente em branco) 


\section{A CASA PÚBLICA}

Nestes exercícios, tendo como repto "A Causa Pública”, tema da XII Semana Cultural da Universidade de Coimbra onde a exposição a que dariam origem se inseria, bastou a queda de uma letra para "A Causa Pública" se transformar em "A Casa Pública”.

A relação com a arquitectura faz-se pelo óbvio e, nestes trabalhos dos alunos de Desenho II, a relação entre o doméstico e o público vai mais longe numa relação entre o individual e o urbano.

As silhuetas recortadas destes corpos assumem aqui o lugar de um terreno de dimensôes ambíguas, numa escala indeterminada que pode ir da escala de um pequeno lugar, à escala de uma cidade, de um país, ou mesmo de um continente.

Como terreno, estes corpos talvez sejam ilhas na afirmação de uma individualidade, mas é uma individualidade que contém o espaço urbano, são indivíduos em que o espaço colectivo é seu espaço interior. Subjectividade que absorve a realidade, subjectividade que se forma nos espaços de relaçáo.

O indivíduo é, de facto, uma causa pública. Não os indivíduos encarados anonimamente numa massa informe mas o colectivo como soma de cada um.

E, nestas silhuetas tomadas como terreno, estes alunos encontraram caminhos que lhes começaram a modelar o espaço e, ao direccionar possibilidades de percursos, a mobilidade assim sugerida desde logo inclui os indivíduos, acolhendo-os, na sua dinâmica, naquelas formas tornadas lugares.

Ao mesmo tempo, estes trabalhos, mais do que maquetas para hipotéticos projectos, assumem a sua dimensão plástica, a sua dimensão de investigação formal.

(estes trabalhos foram apresentados numa exposição que integrava também participaçóes de alunos dos cursos de Design e Multimédia, das disciplina de Estudos de Composição, de Design II, de Design e Comunicação e de Expressão Plástica e Multimédia). 
(Página deixada propositadamente em branco) 


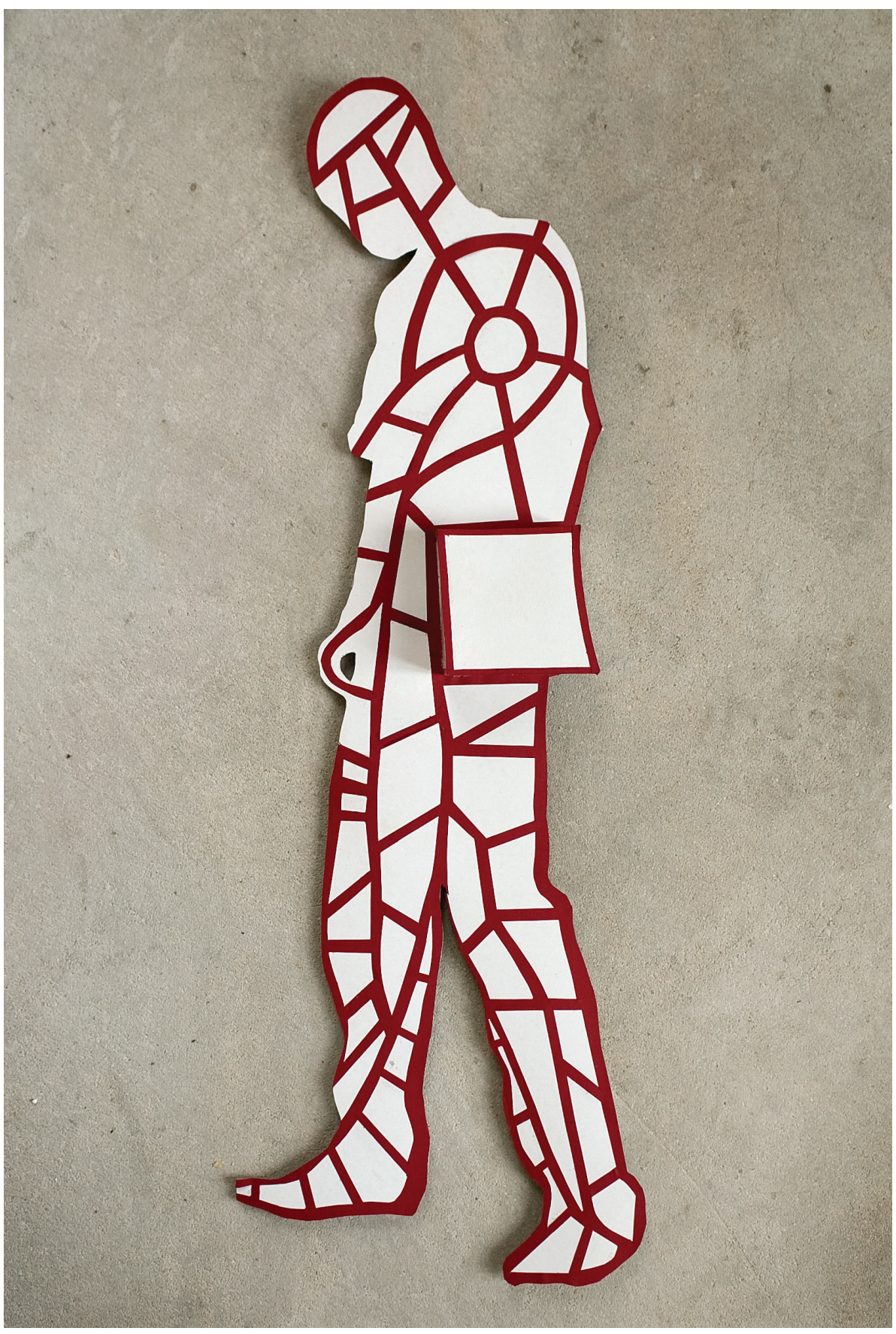




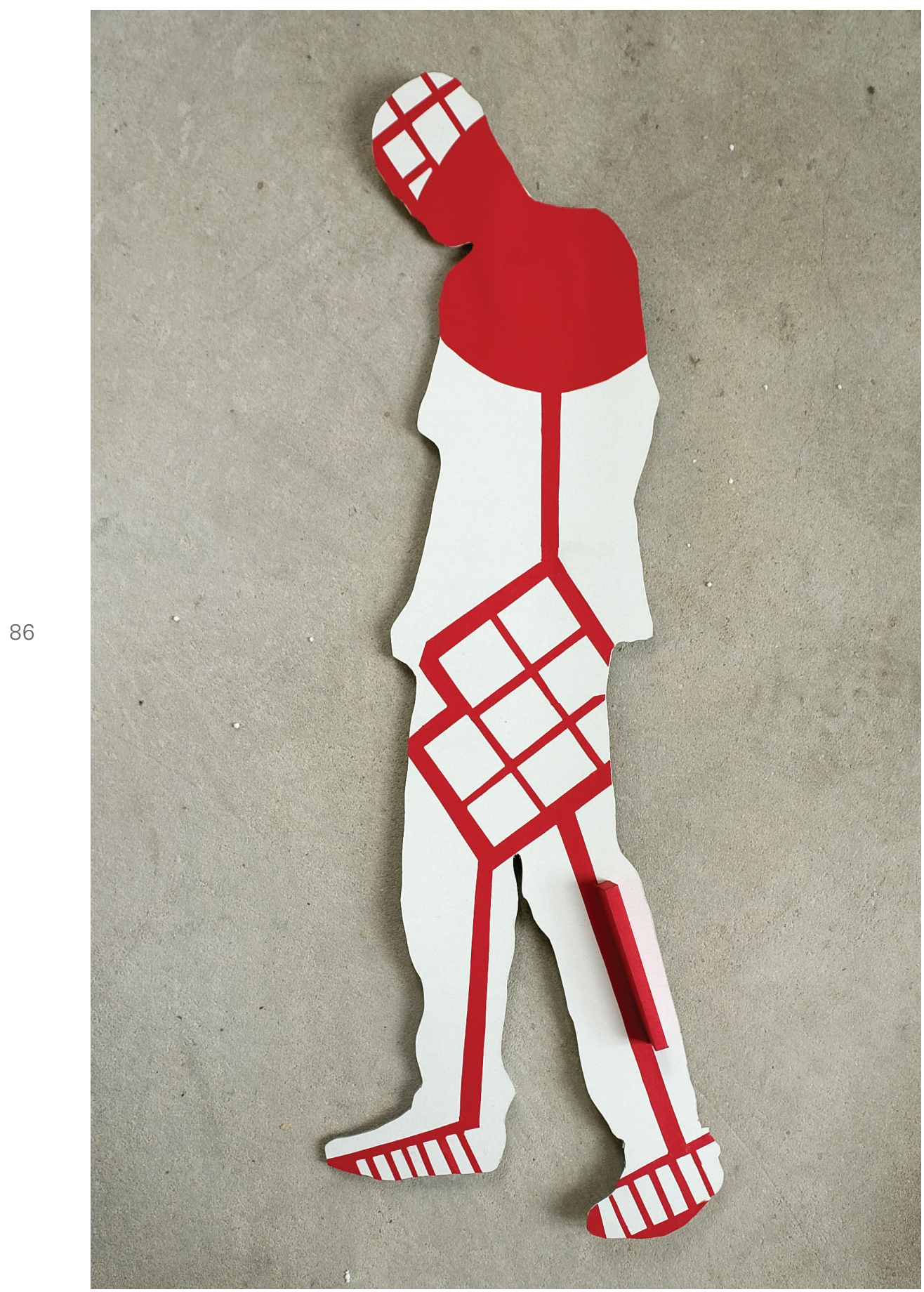

Adilson Semedo 


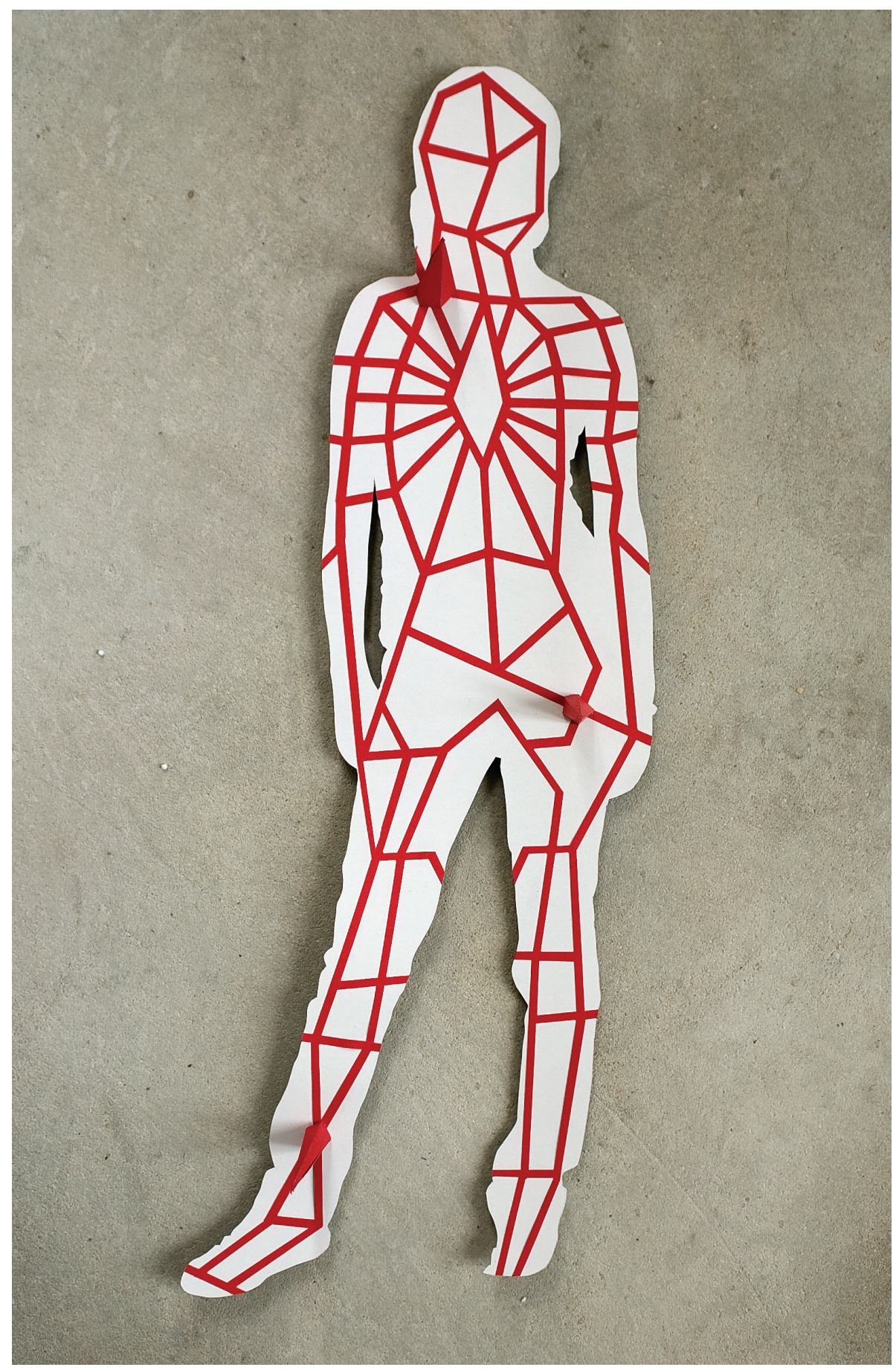




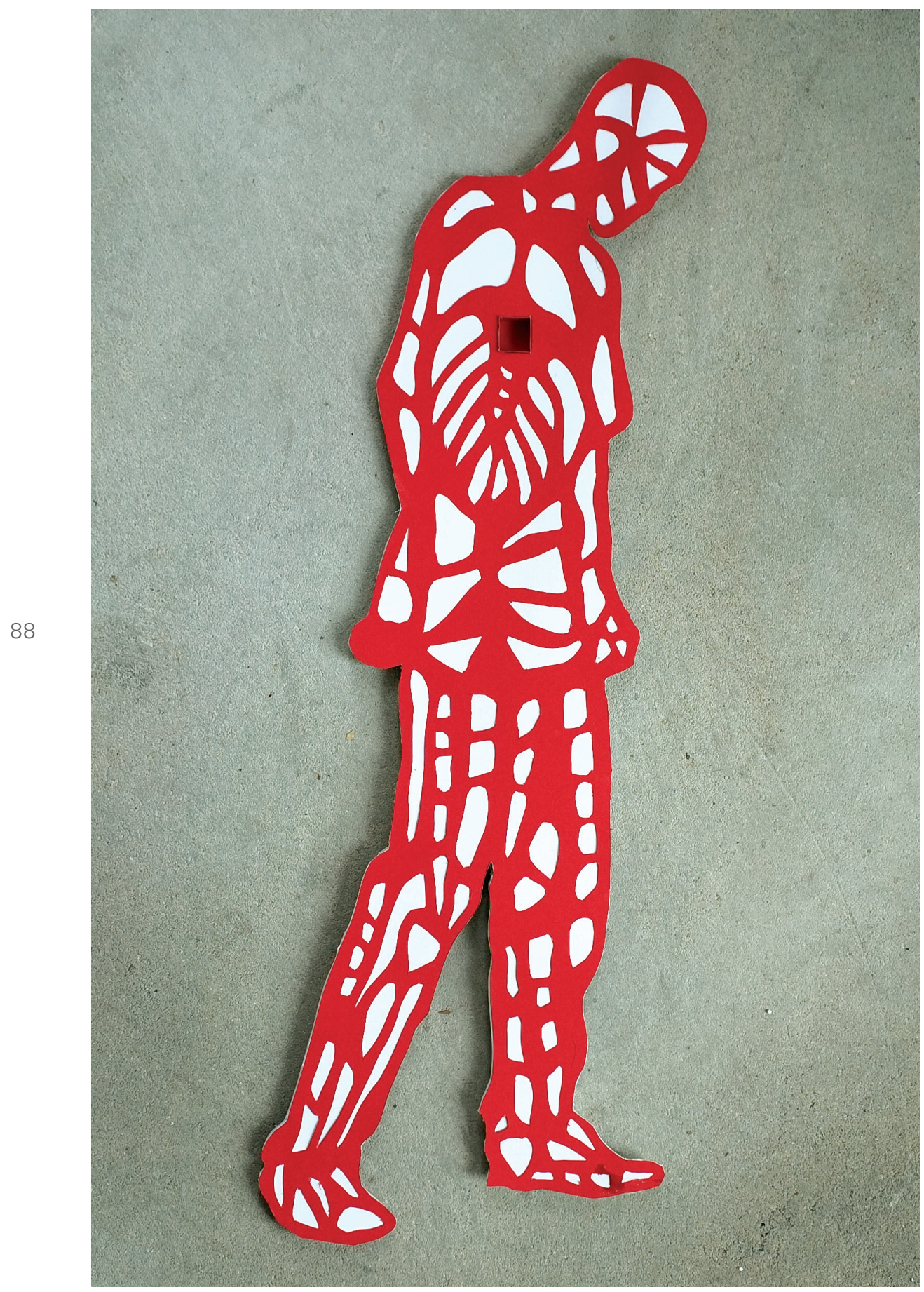

Alexandra Zahorski 


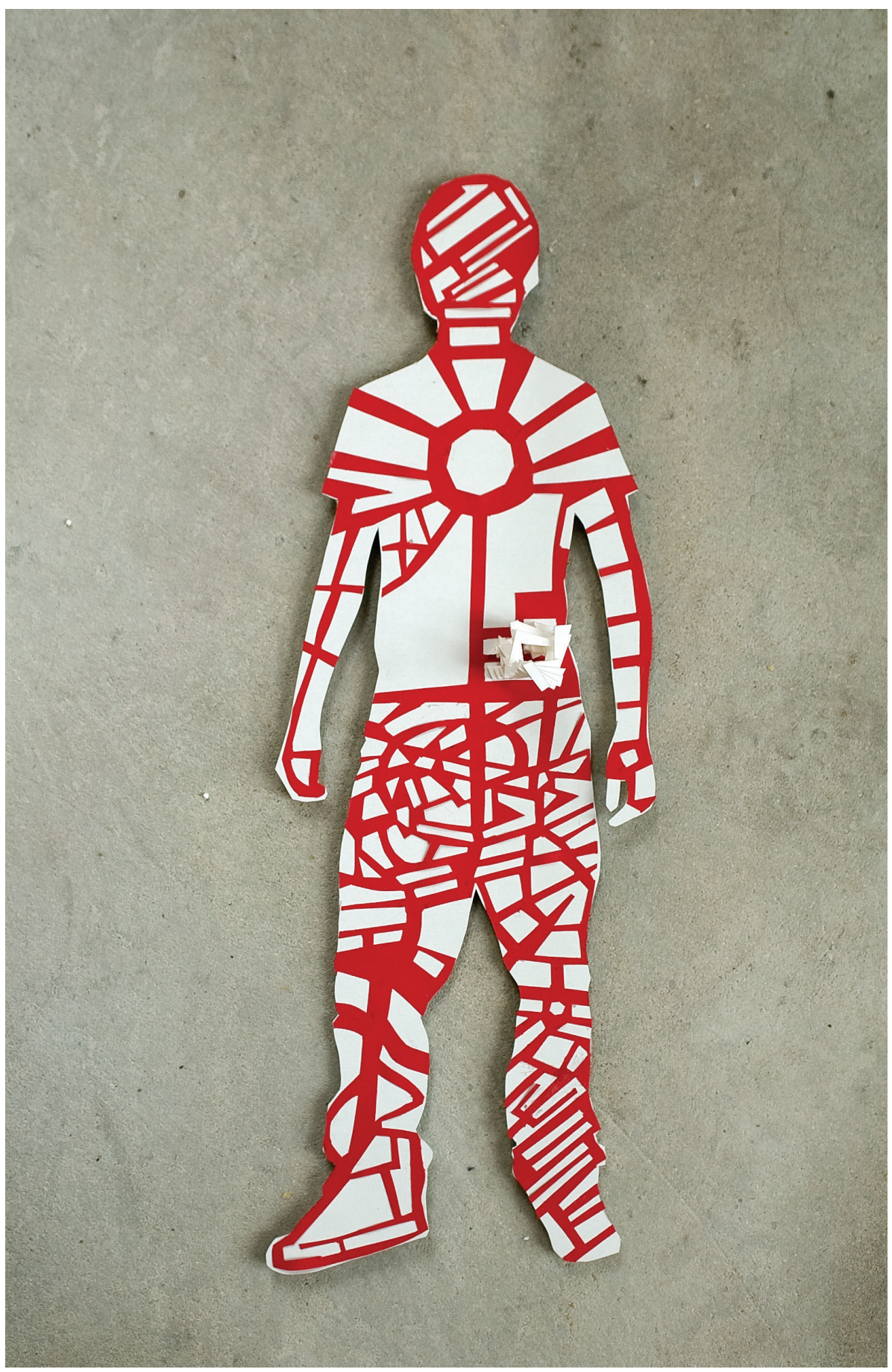




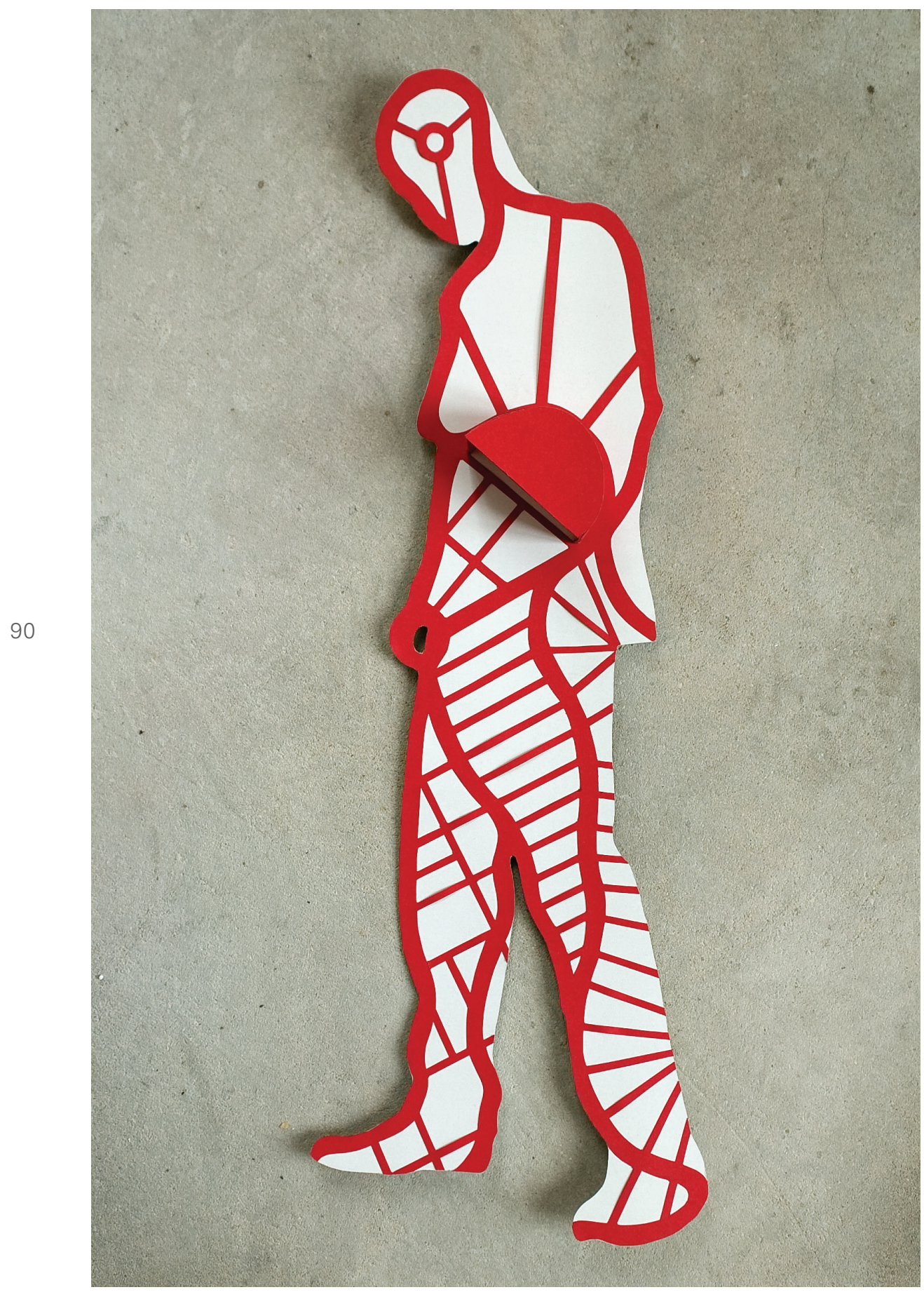

Inês Parreira 


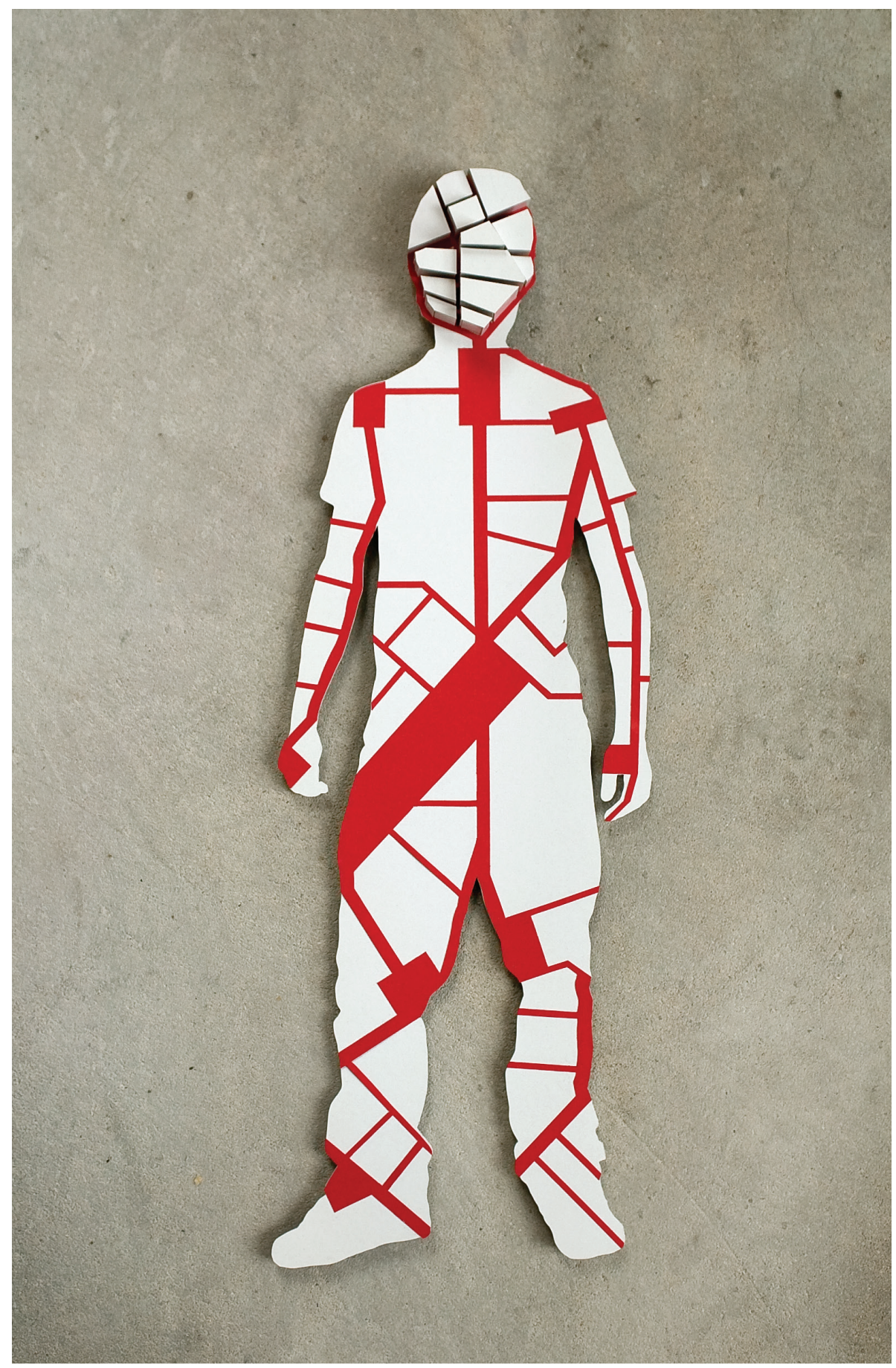




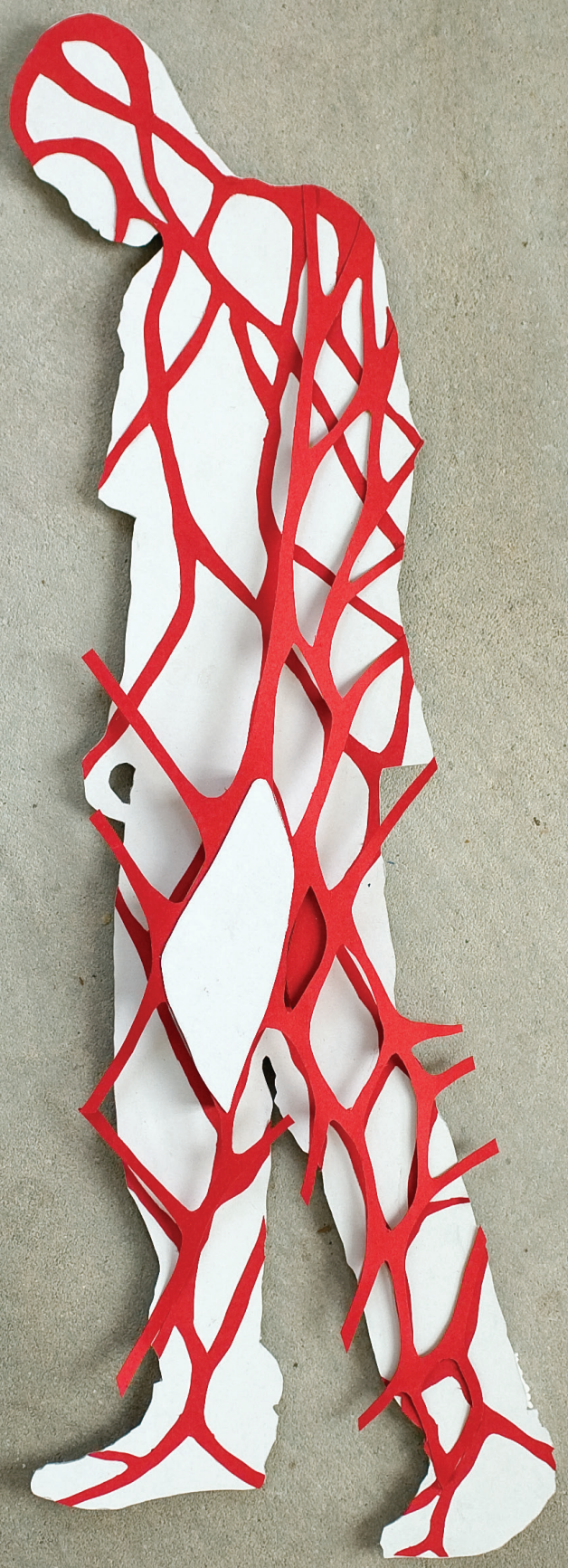

Miguel Mesquita 


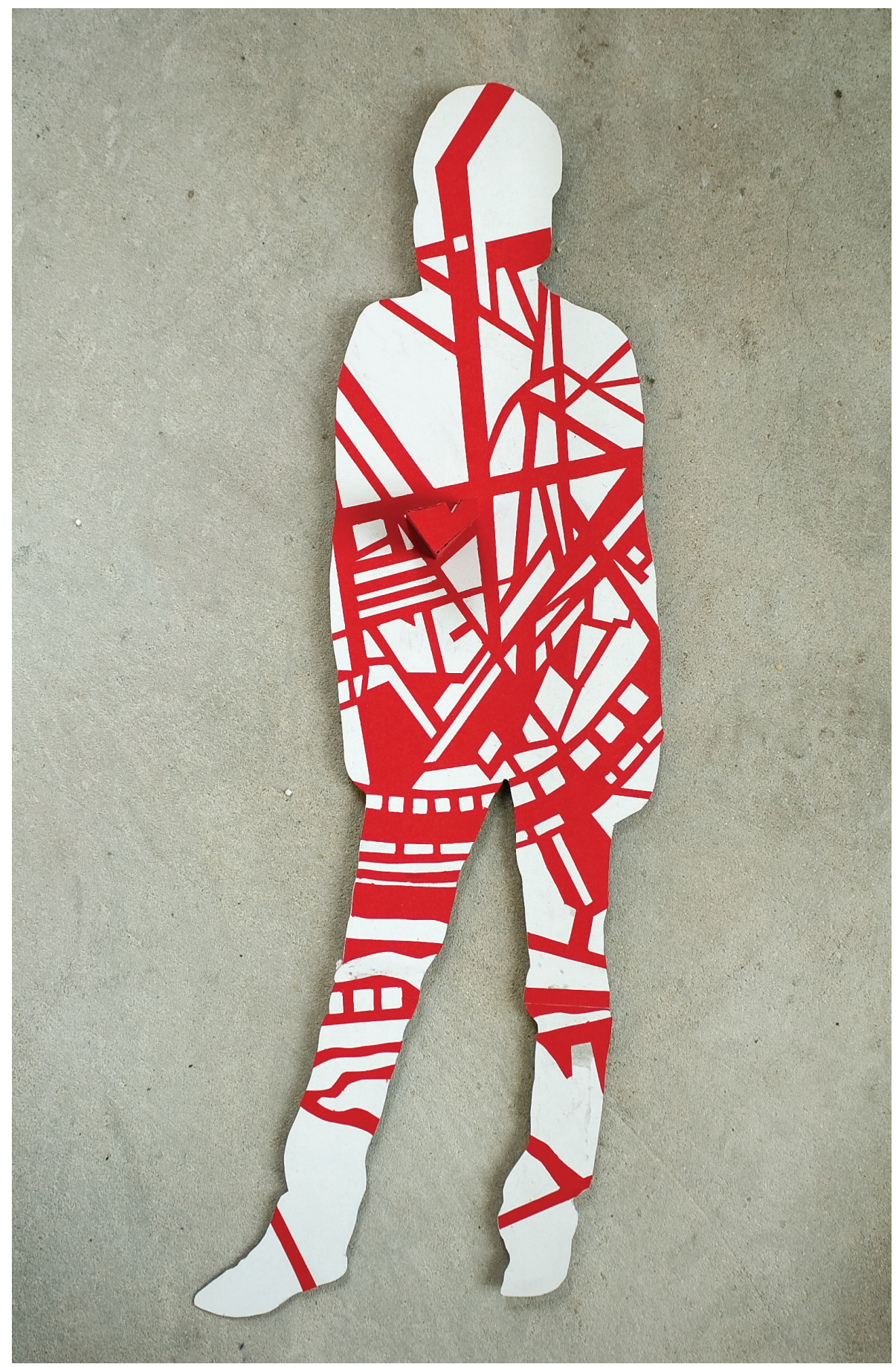




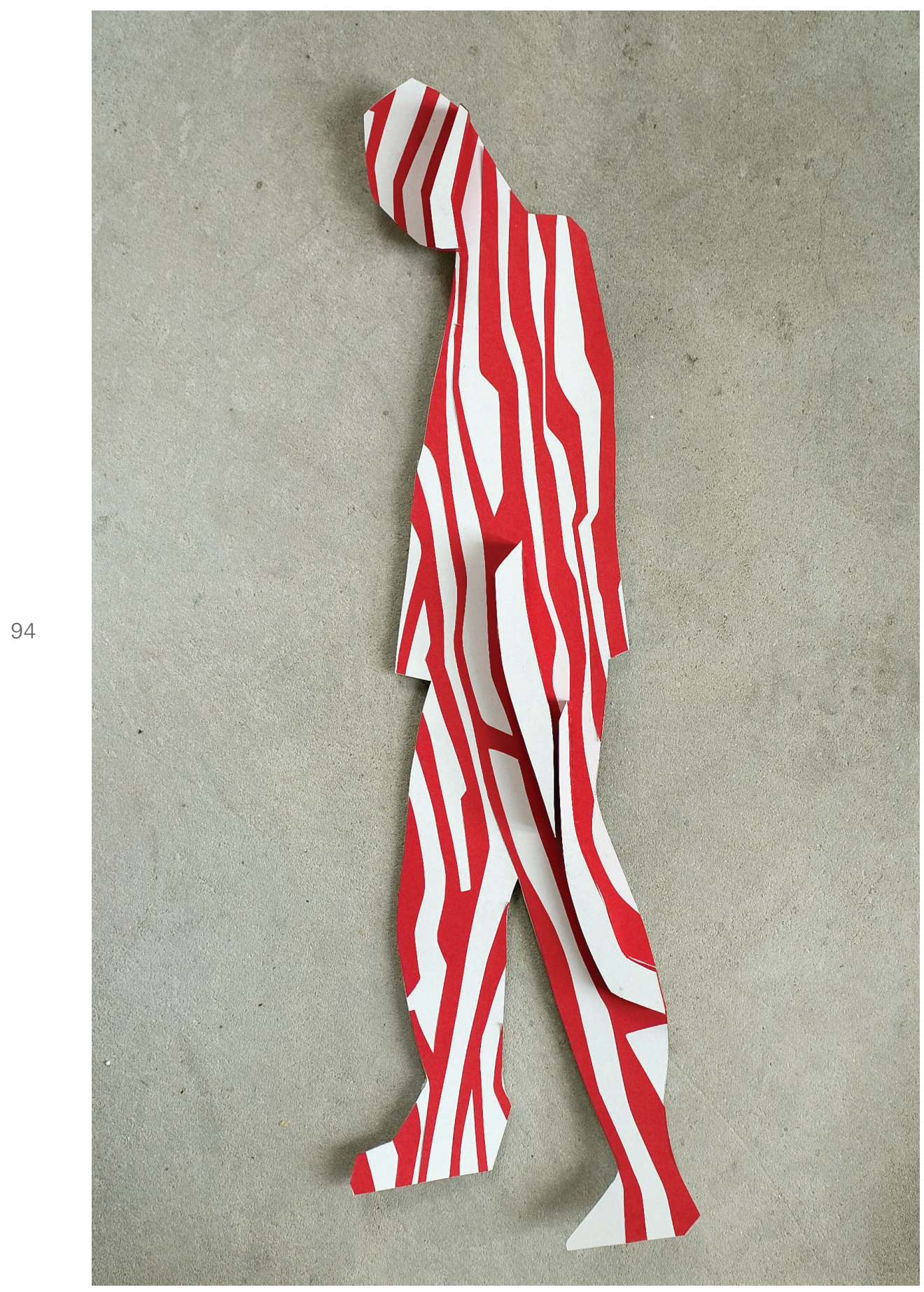

Pedro Mendes 


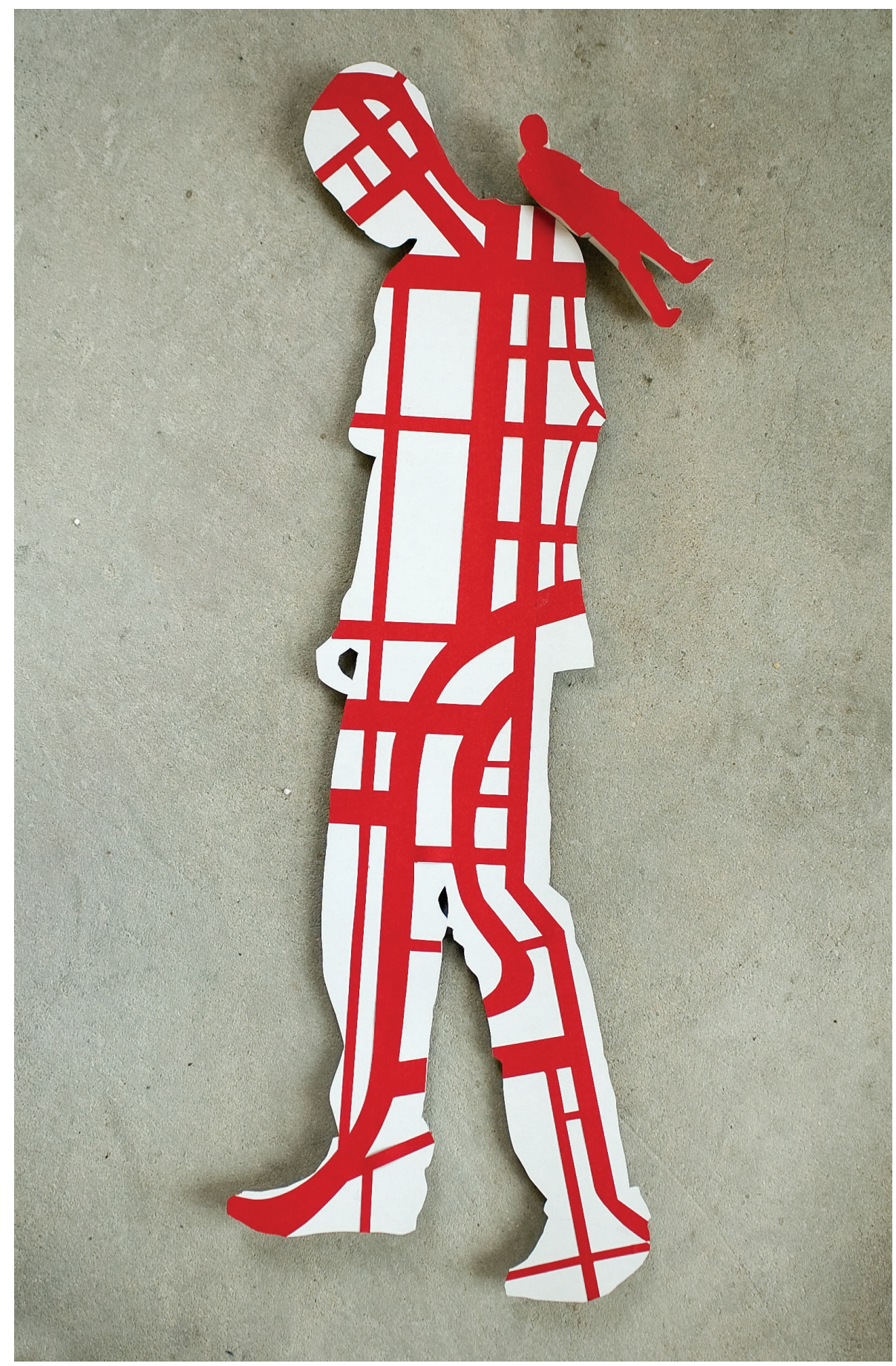




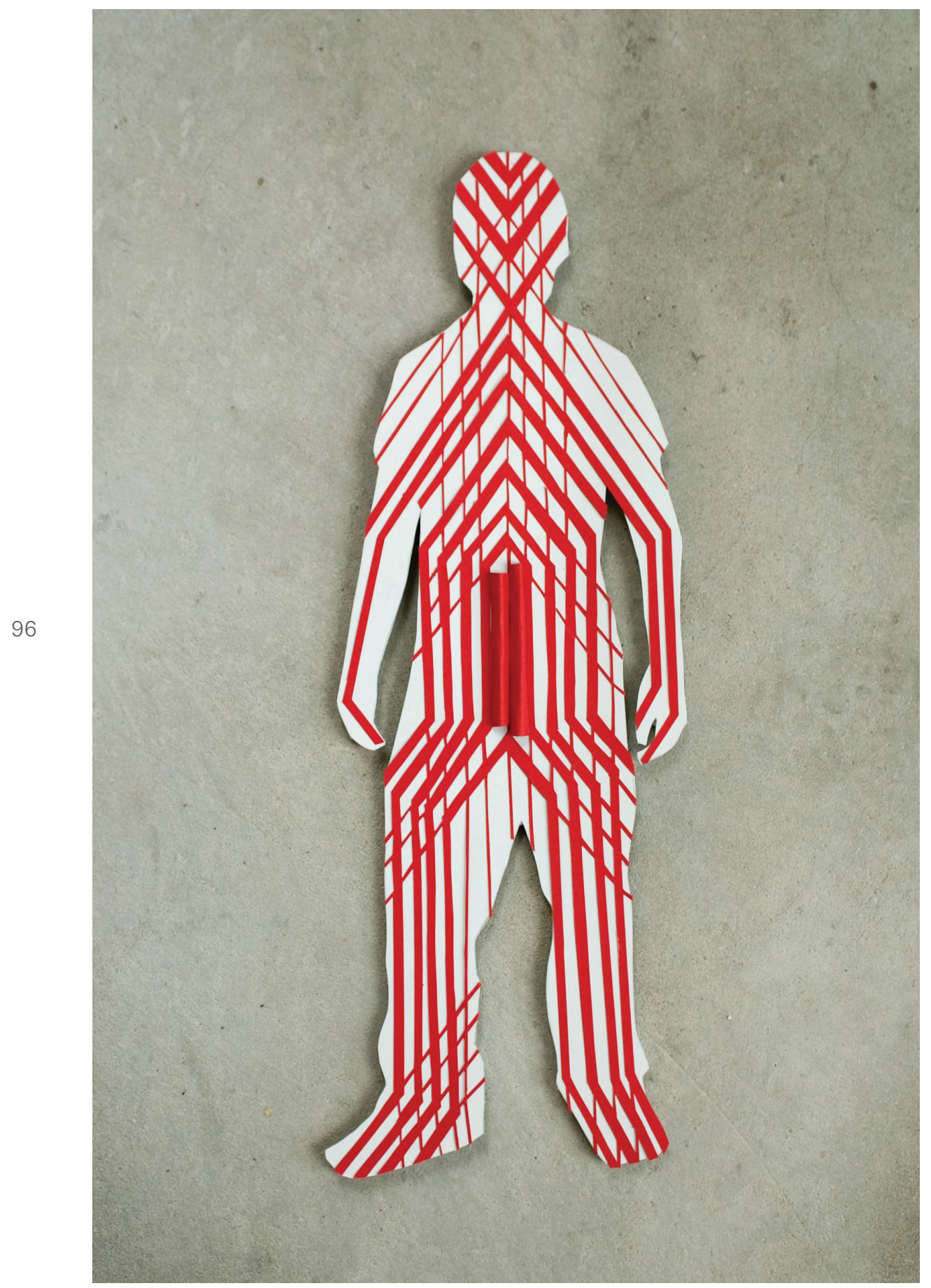

Ana Catarina Fontes 


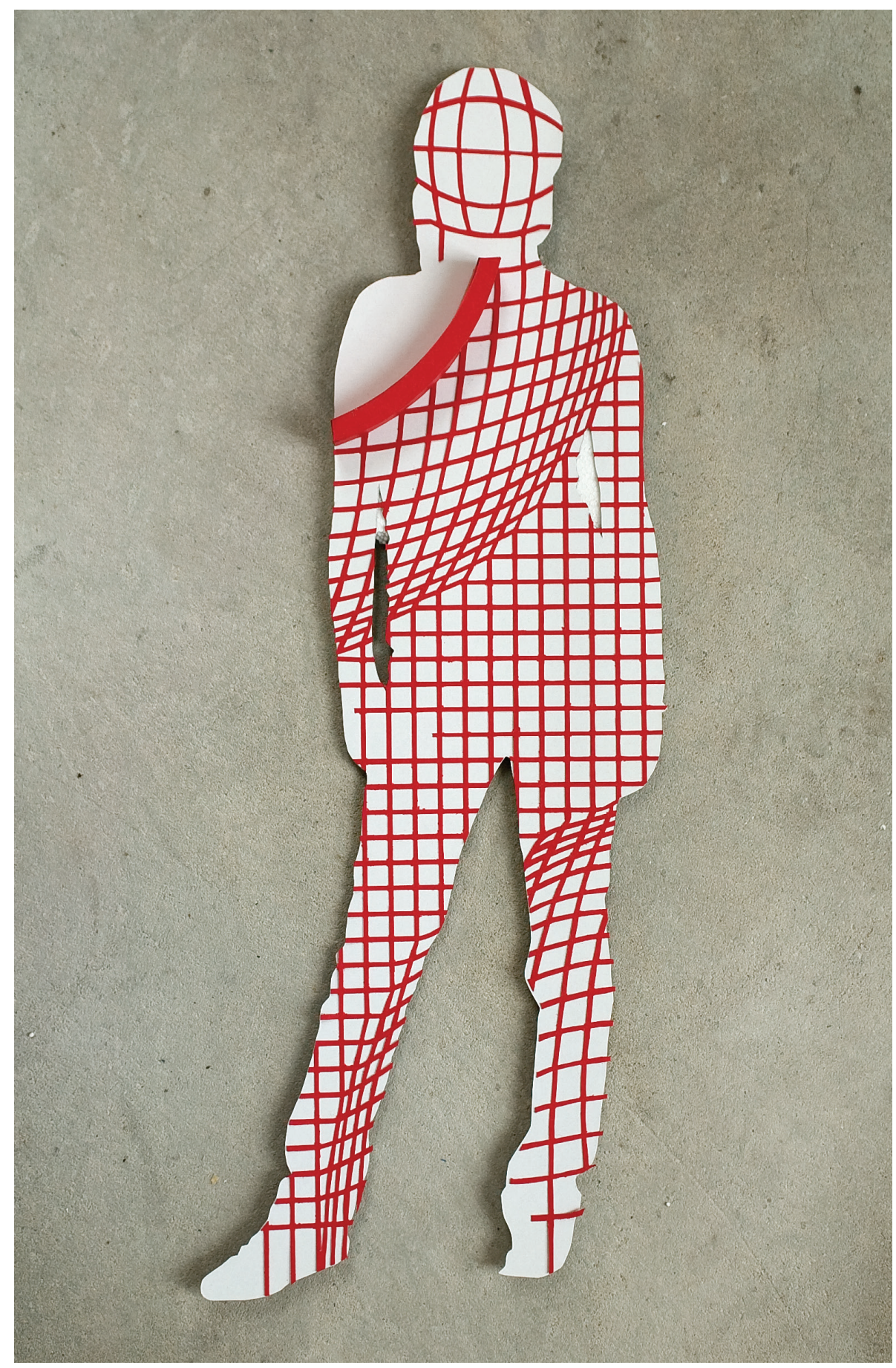




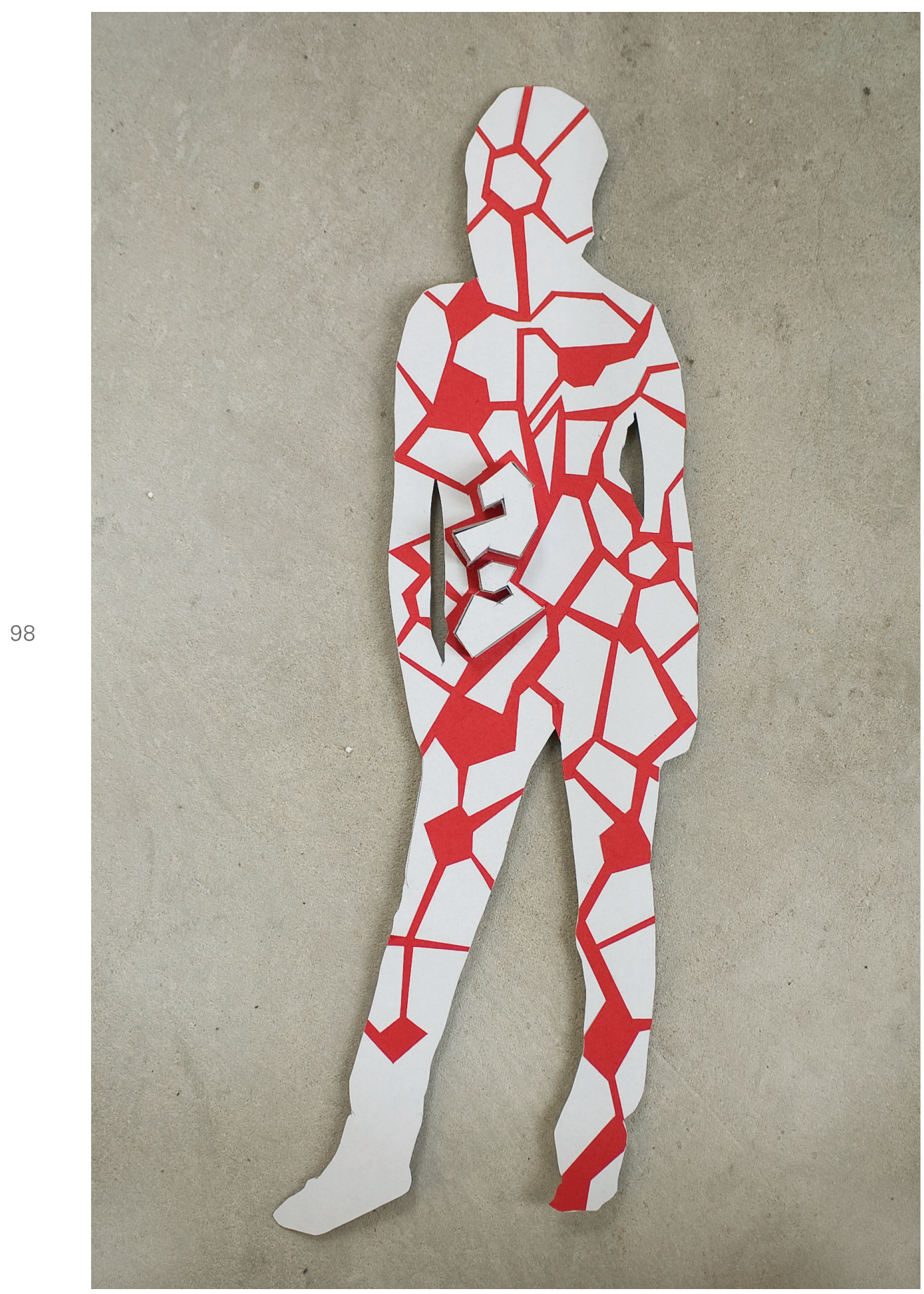

Cláudia Franco, 


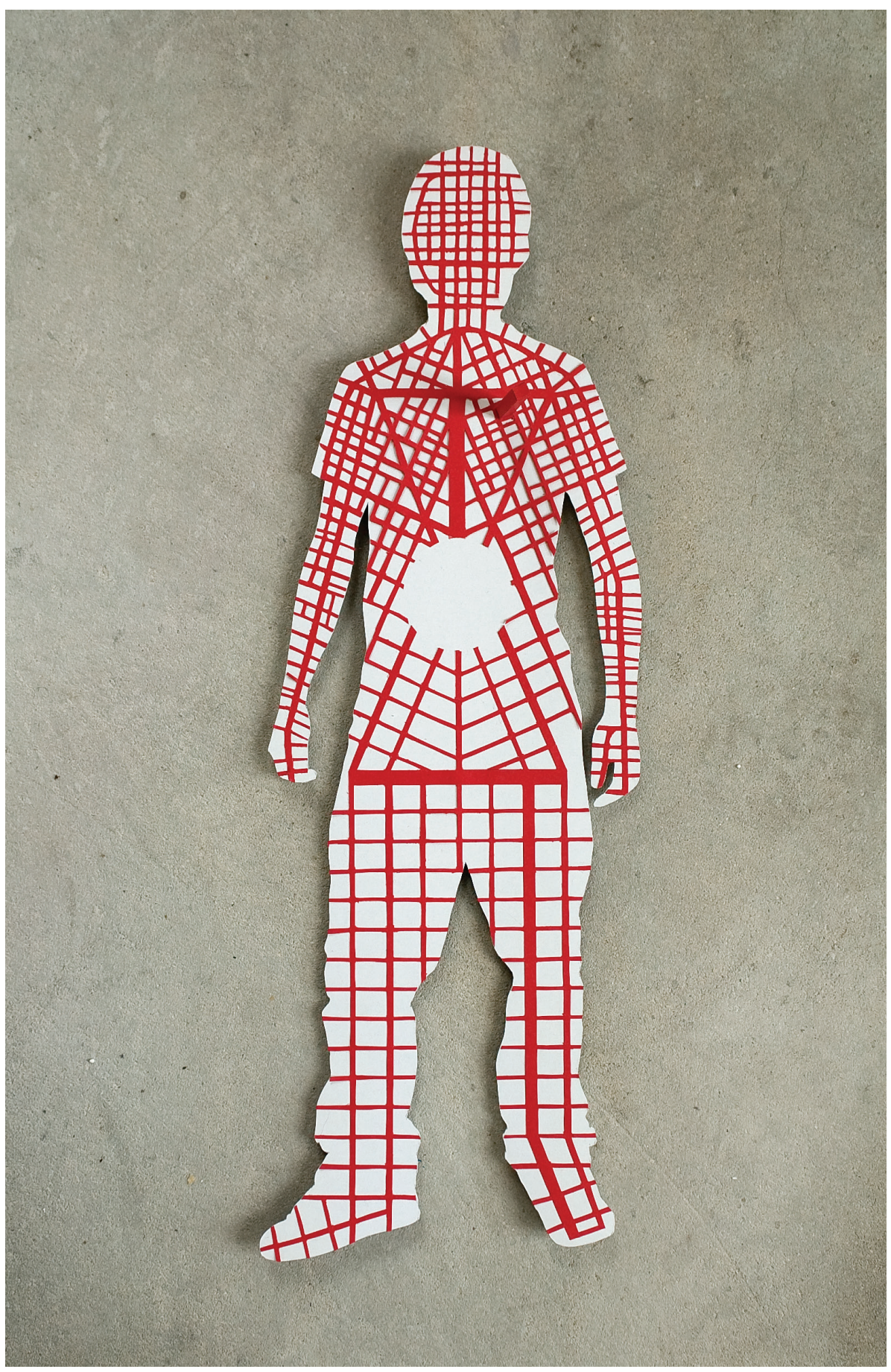




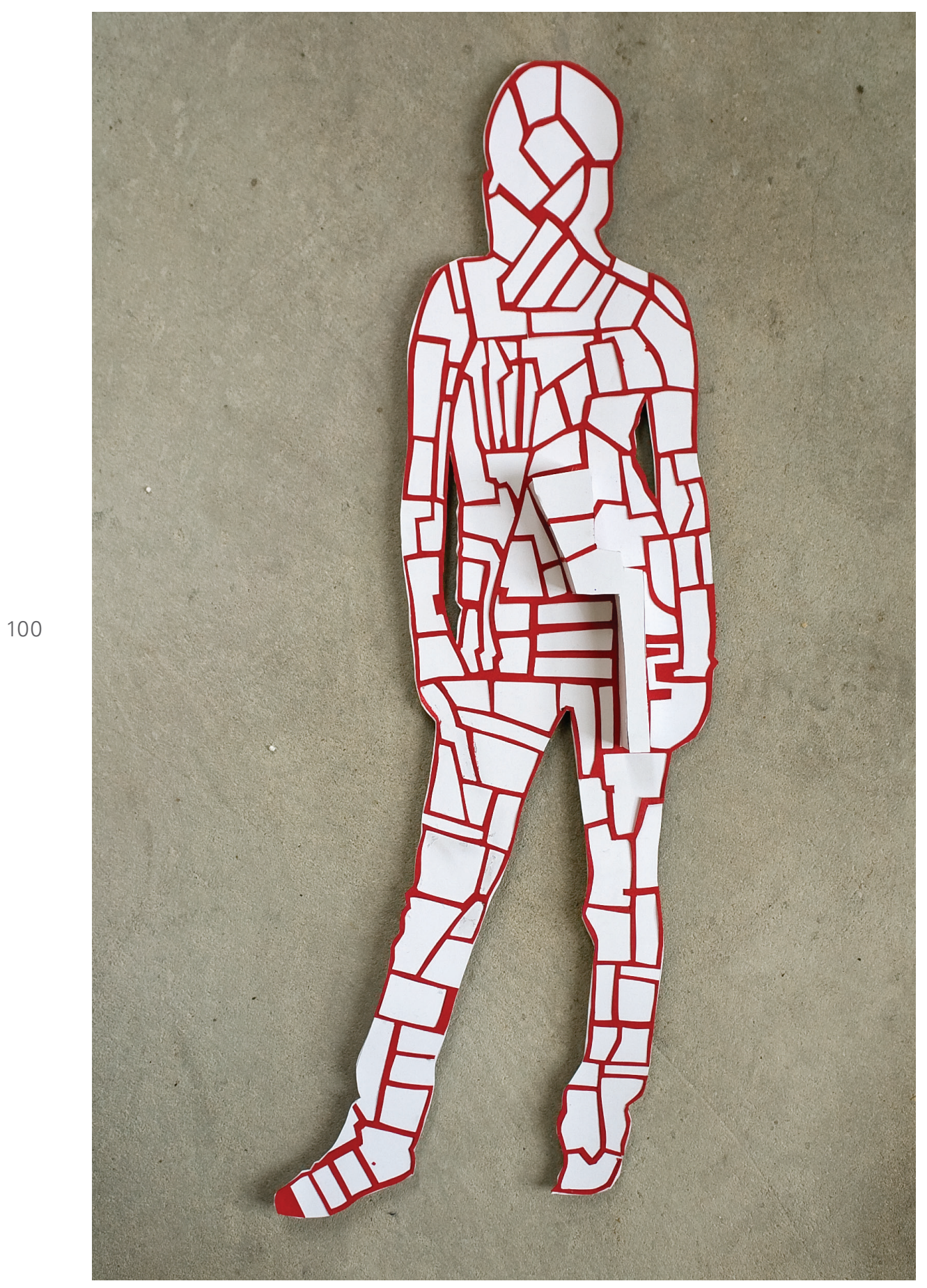




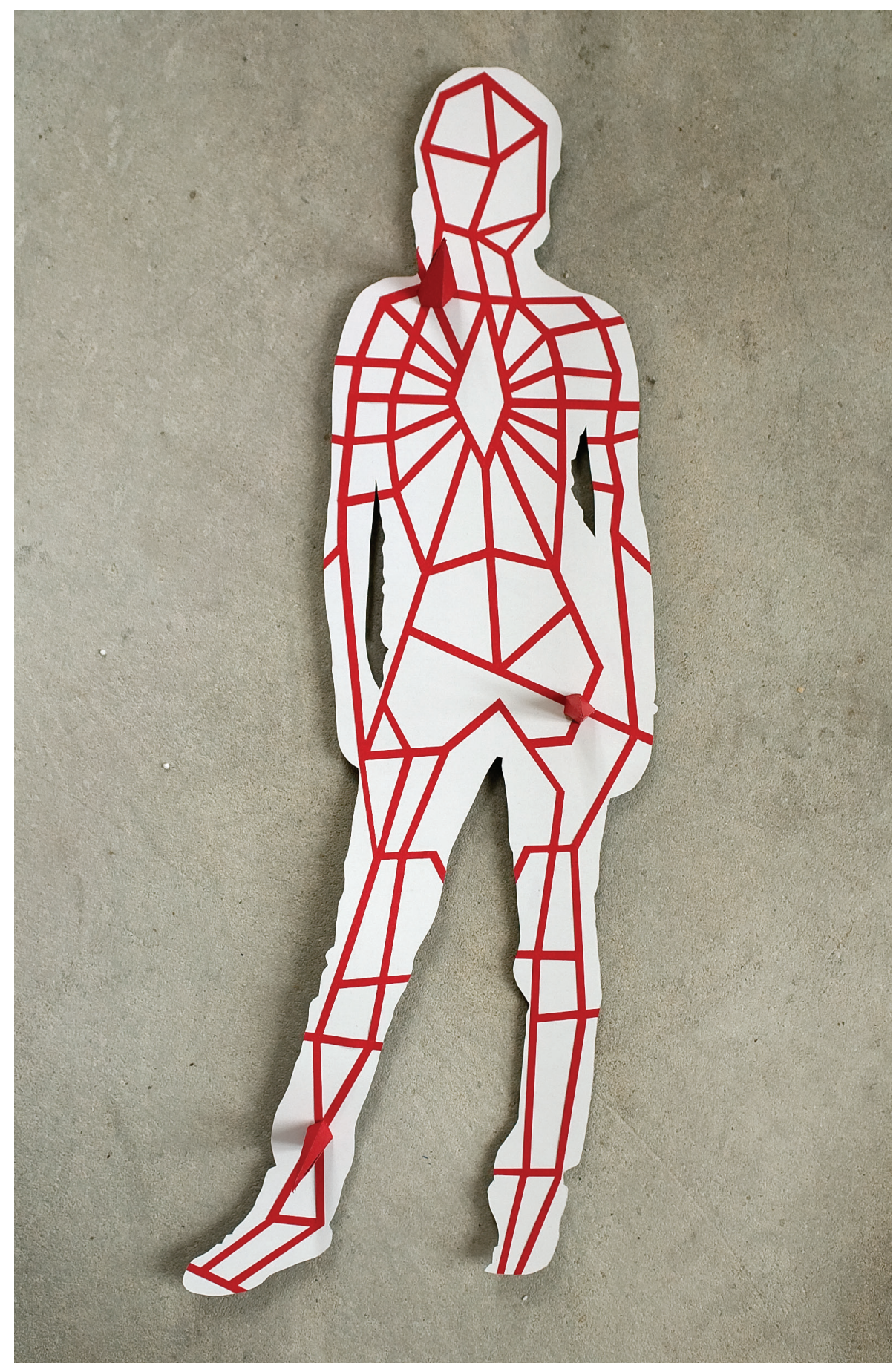



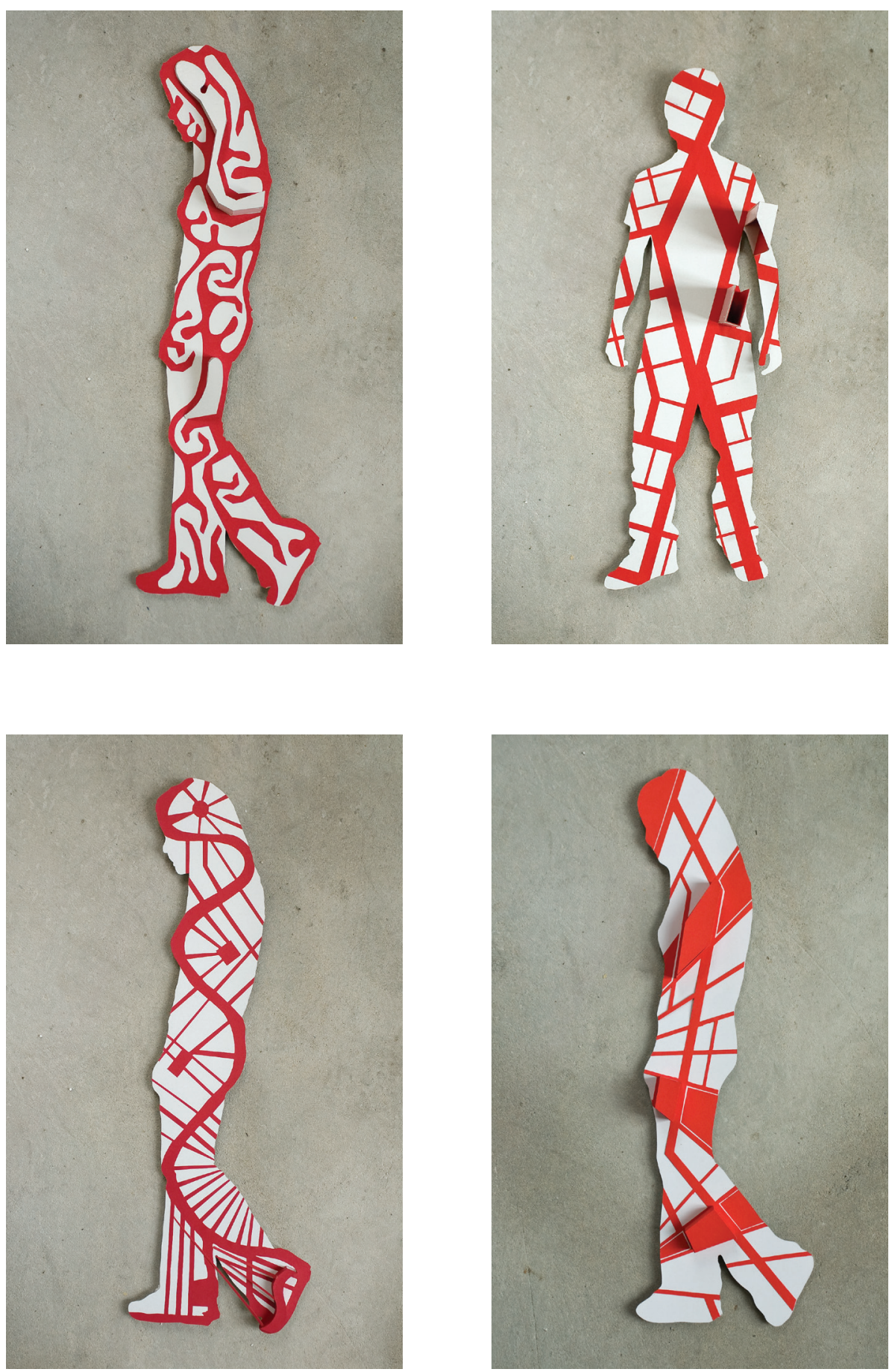

Fátima Subida, Graça Barbosa, Tânia Oliveira, André Pimentel 

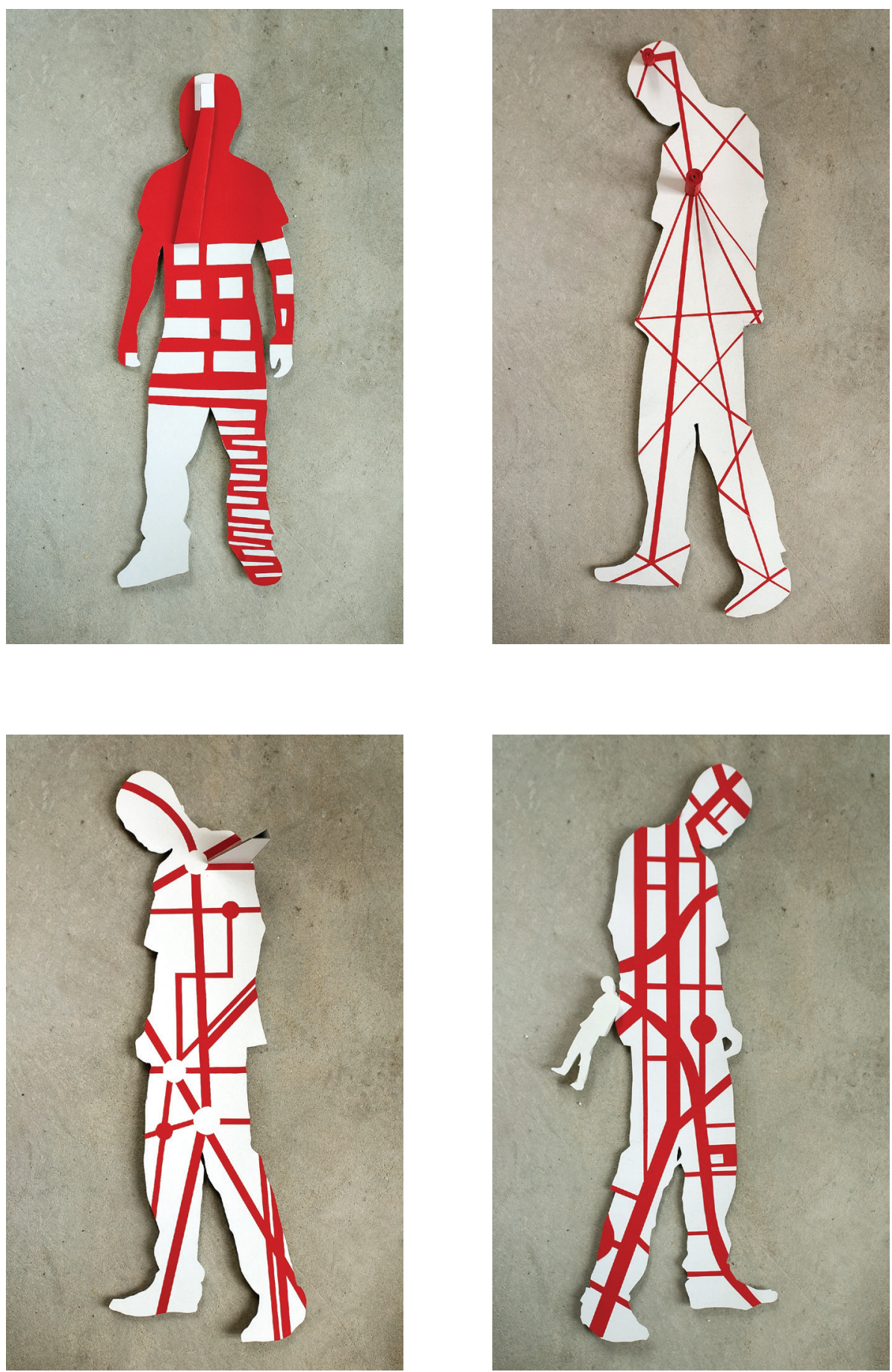

Inês Andrade, Ivanildo tavares, João Cordeiro, José Miguel Martins 

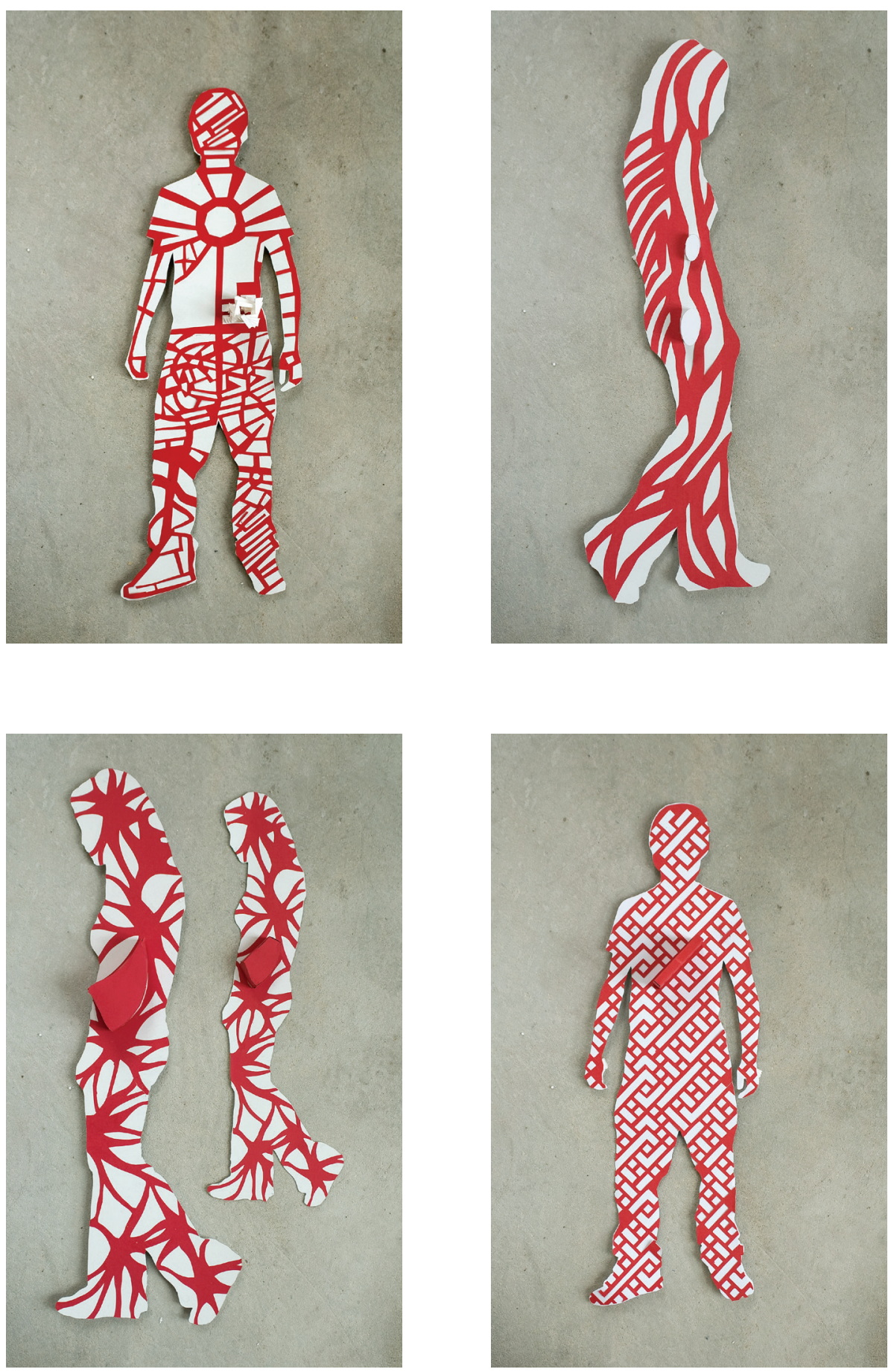

Márcio Pereira, Marta Silva, Paulo Barata, Pedro Silva 

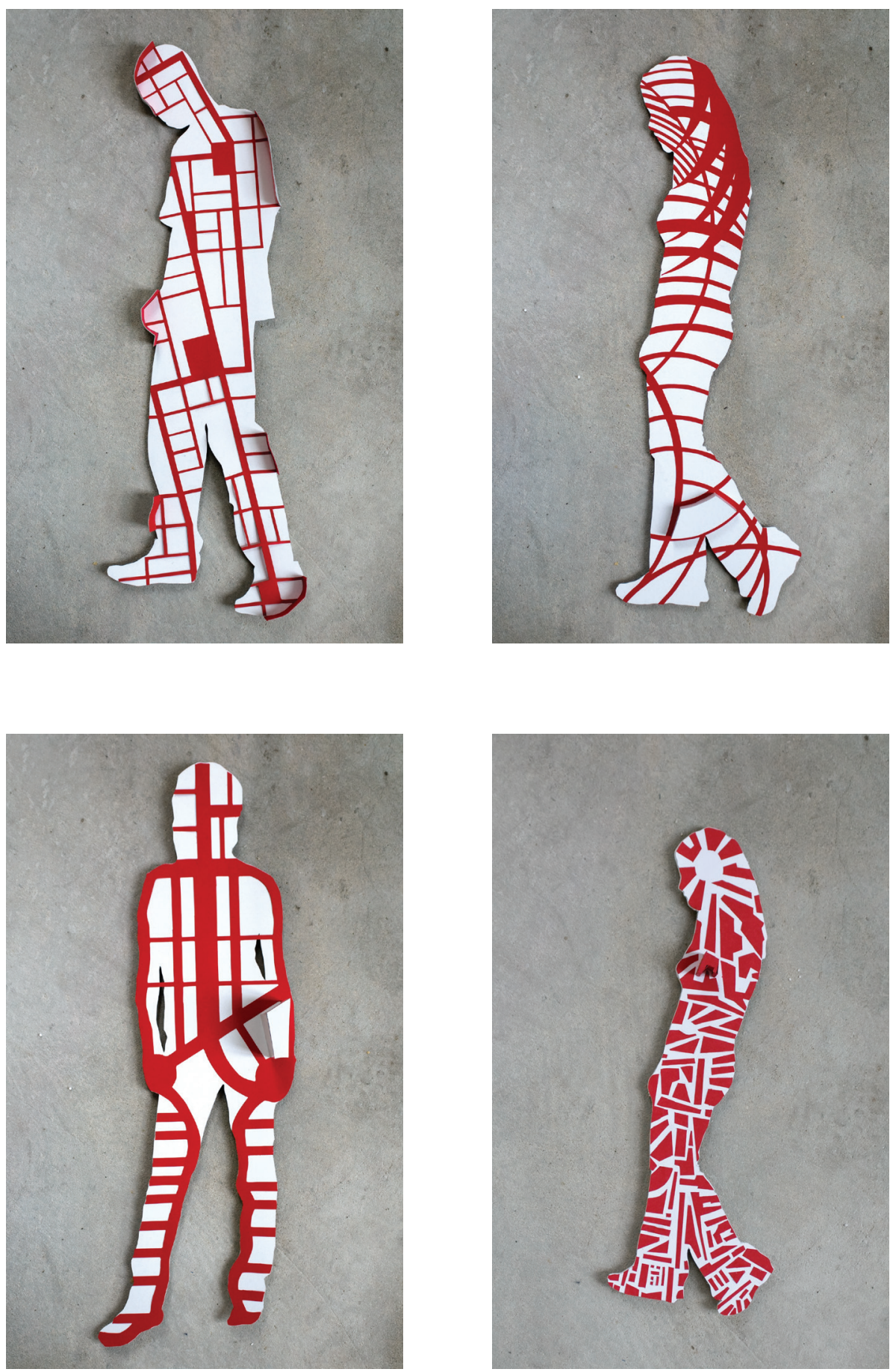

Fernando Couto, Fátima Subida, Joana Oliveira, Mariana Abrantes 

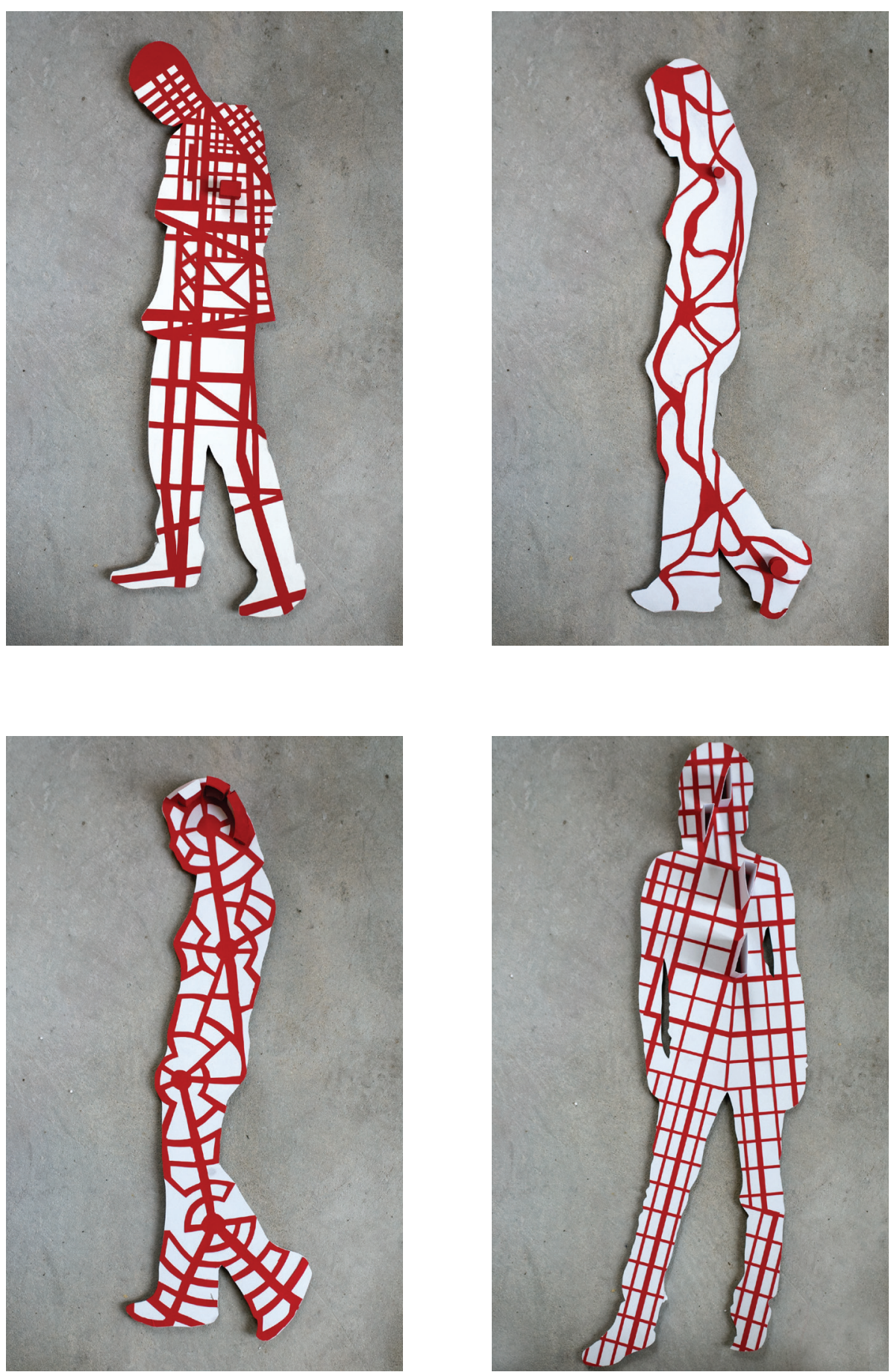

José Martins, Laura Deus, Leandro Monteiro, Alexandre Azevedo 

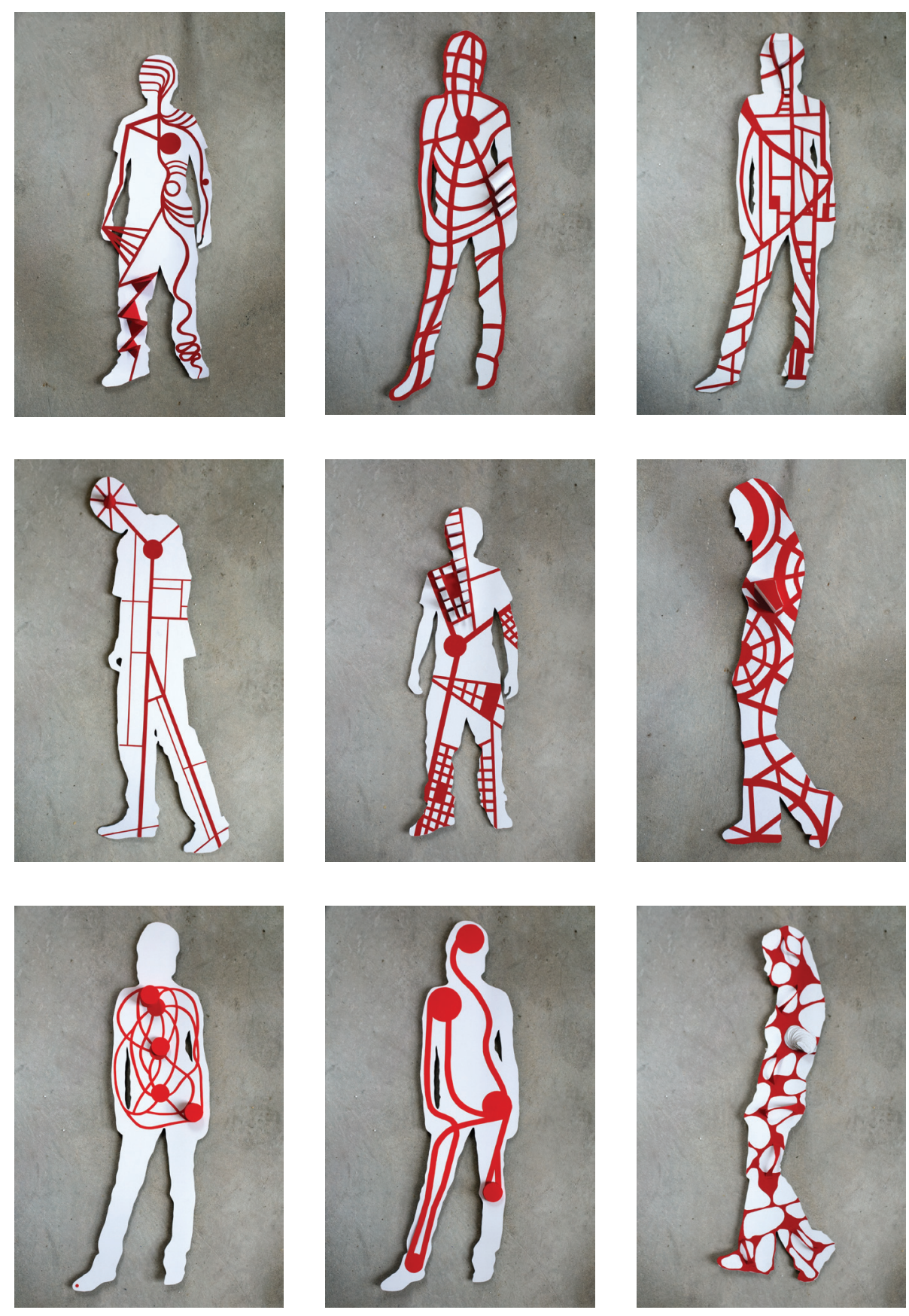

Vitor Sousa, Vanessa Batista, Joana Vaz, Ana Lídia Nogueira, Fábio Castro , Tânia Correia, Ana Lisa Relvão, Ana Cristina Ramos, 

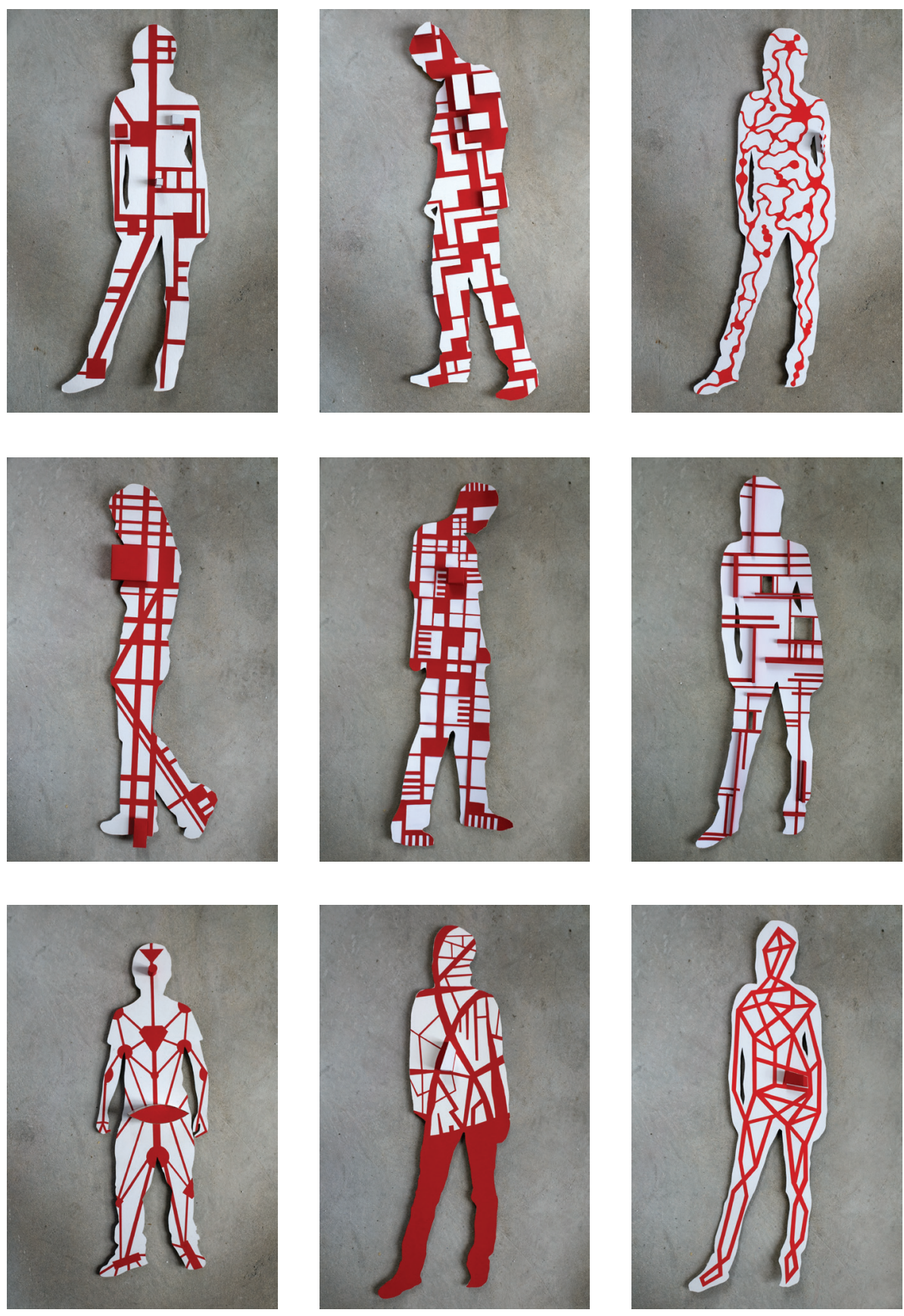

Mafalda Cabeleira, Mariana Campos, Mariana Carvalho, Marta Brás, Marta Stachurska, Nadja Fonseca, Nelson Ladeira, Paulo Dias, Pedro Ferreira 

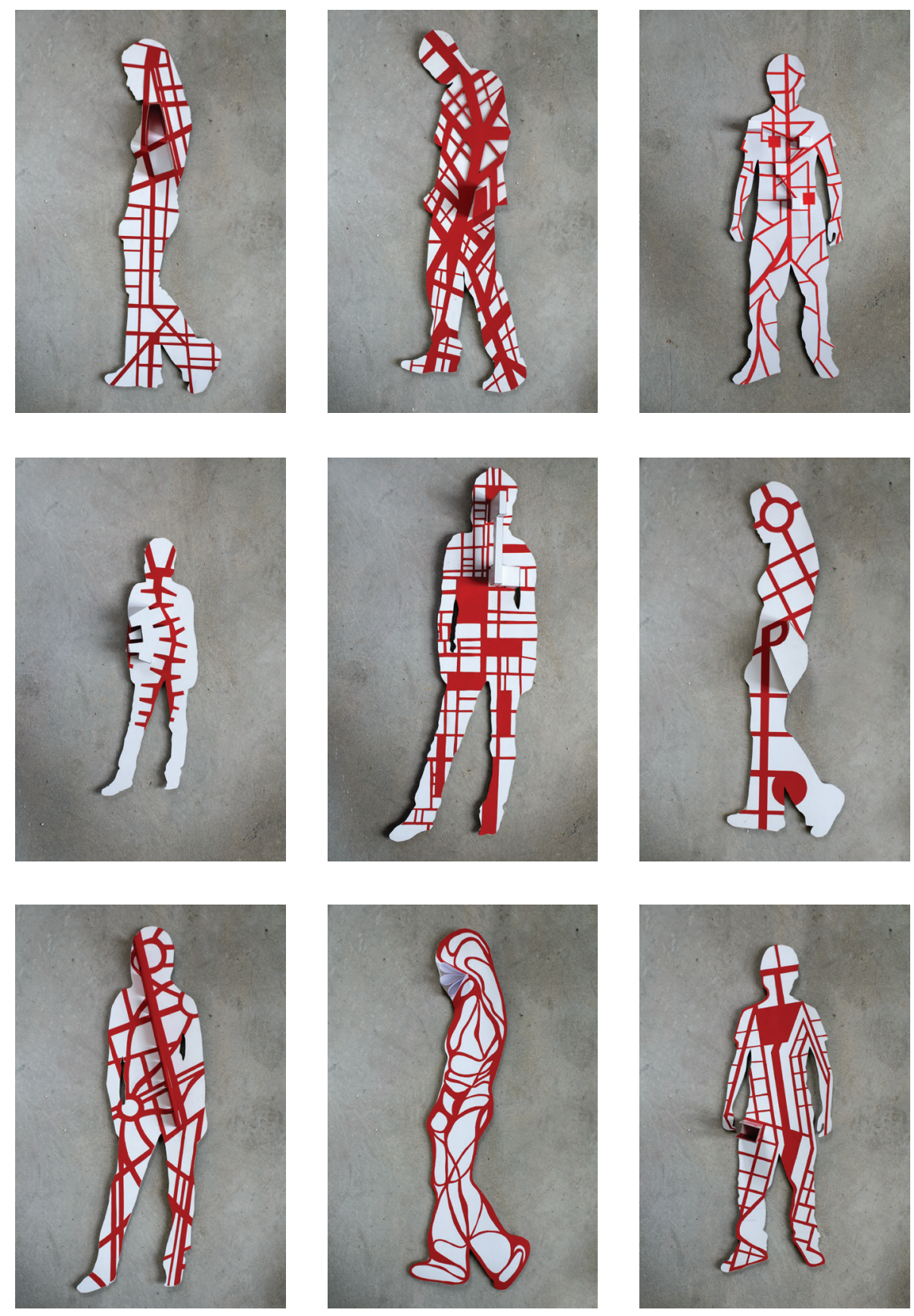

Pedro Filipe Santos, Pedro Oliveira, Ruben Domingues, Sara Domingues, Silvia Romão, Simão Antunes, Sofia Fernandes, Suse Almeida, Ana Cláudia Silva 
(Página deixada propositadamente em branco) 


\section{COIMBRA x COIMBRA}

Multiplicar Coimbra por Coimbra, partir da ideia de Coimbra ao quadrado, mais do que procurar uma redundância, resulta certamente (tratando-se aqui de um estímulo à produção plástica) na criação de novas formas.

Para estes exercícios, os alunos apropriaram-se de fotos de Coimbra, mais ou menos pitorescas, aproximando-se, para se afastar, das expectativas de um postal ilustrado.

Lendo sobretudo os seus aspectos formais na bidimensionalidade do enquadramento fotográfico, geraram novas formas, em desenhos sucessivos até estabilizarem em soluçóes que satisfizessem a relação entre a imagem fotográfica e as formas que este processo de transformação gerou.

As formas criadas a cartolina preta não se limitam a emoldurar as fotos que as originaram. Quebram a condição de moldura para invadir as fotos e por elas serem invadidas, sobretudo na forma como as fotos originais ajudam a determinar as formas geradas.

De certa forma, mais do que um exercício puramente plástico, o conjunto destes trabalhos reflectem a condição de uma cidade ser sempre múltipla, na forma como a dinâmica transformadora da sua vitalidade constitui a sua própria identidade. 
(Página deixada propositadamente em branco) 

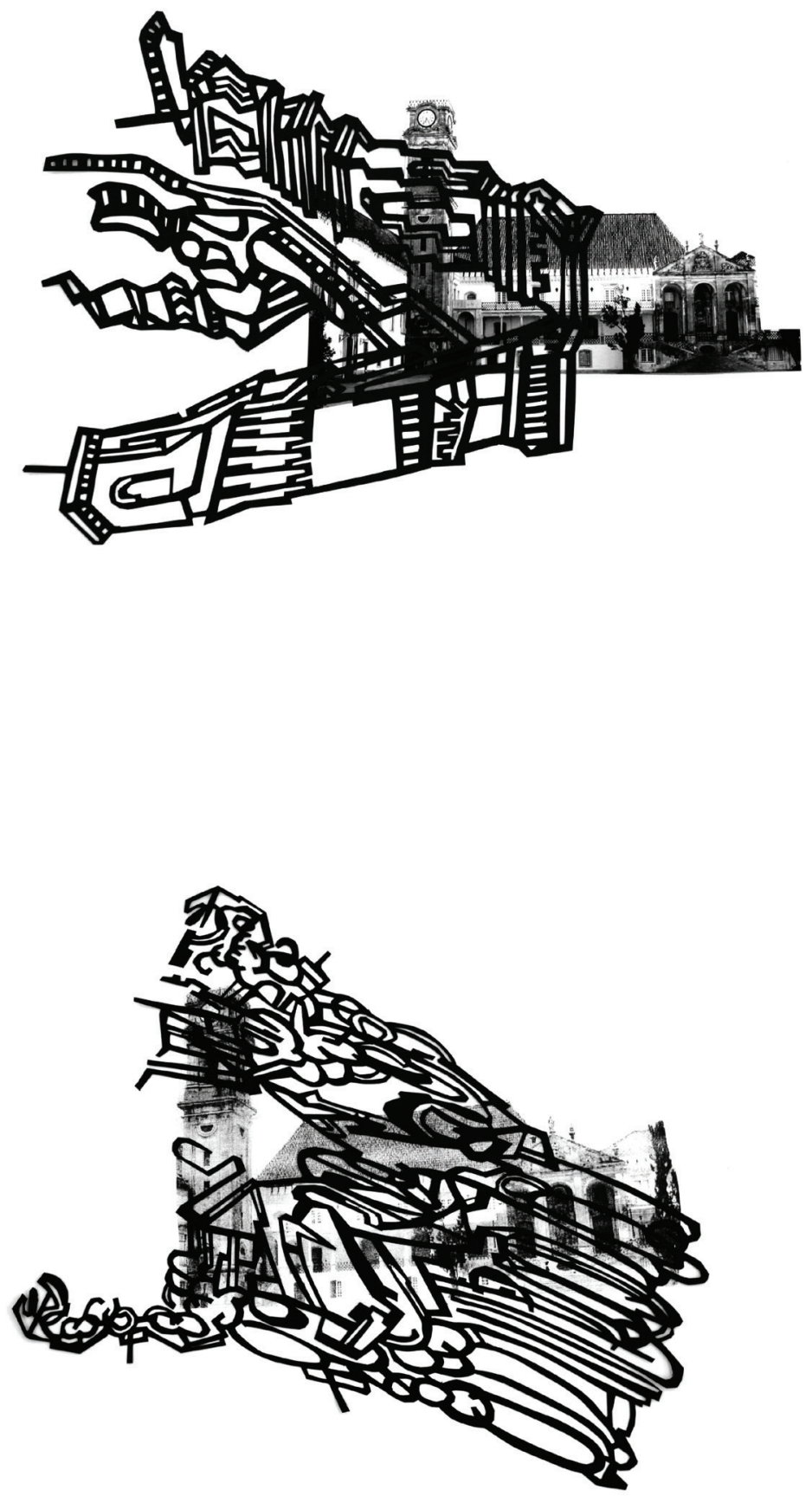

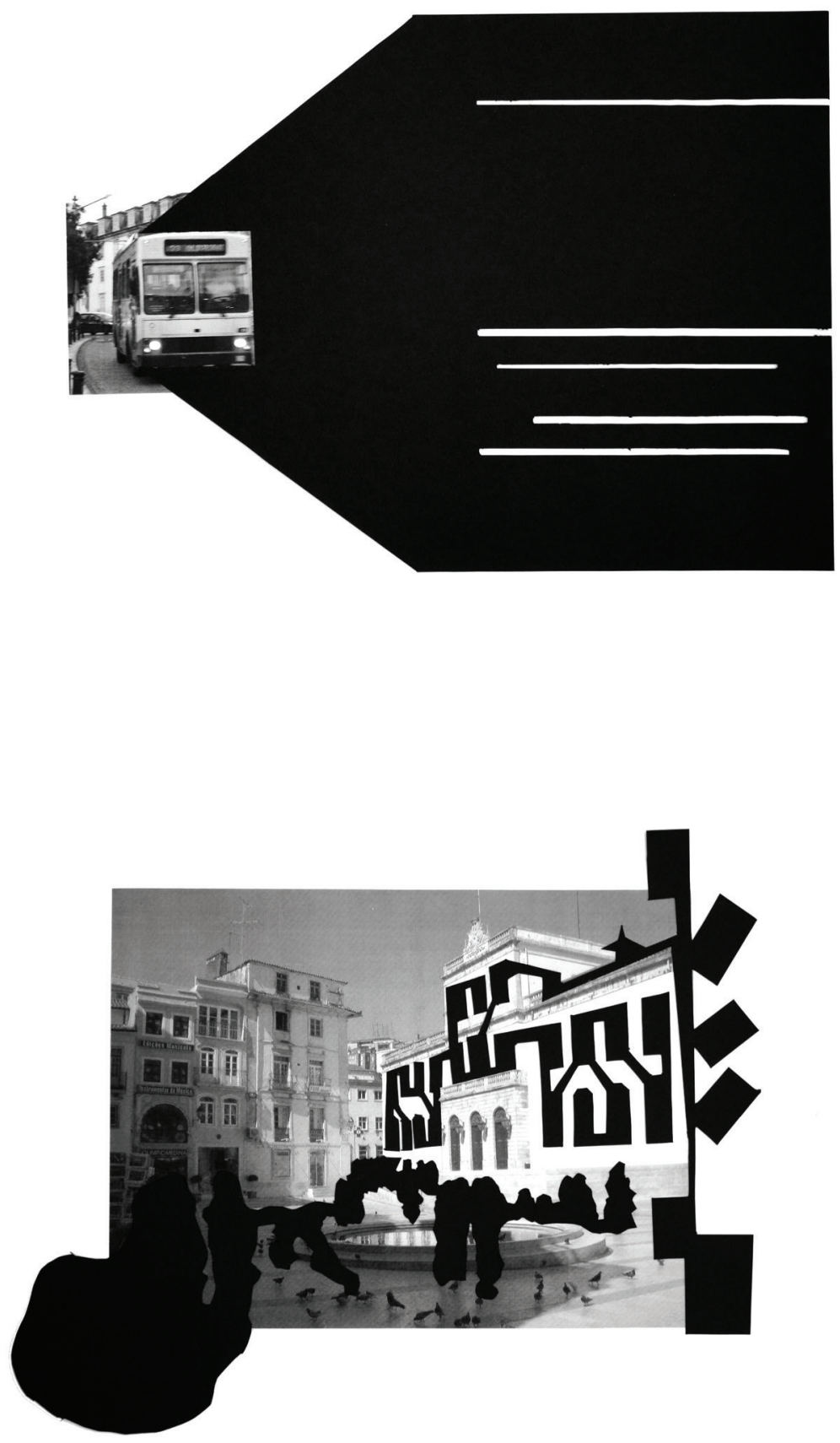


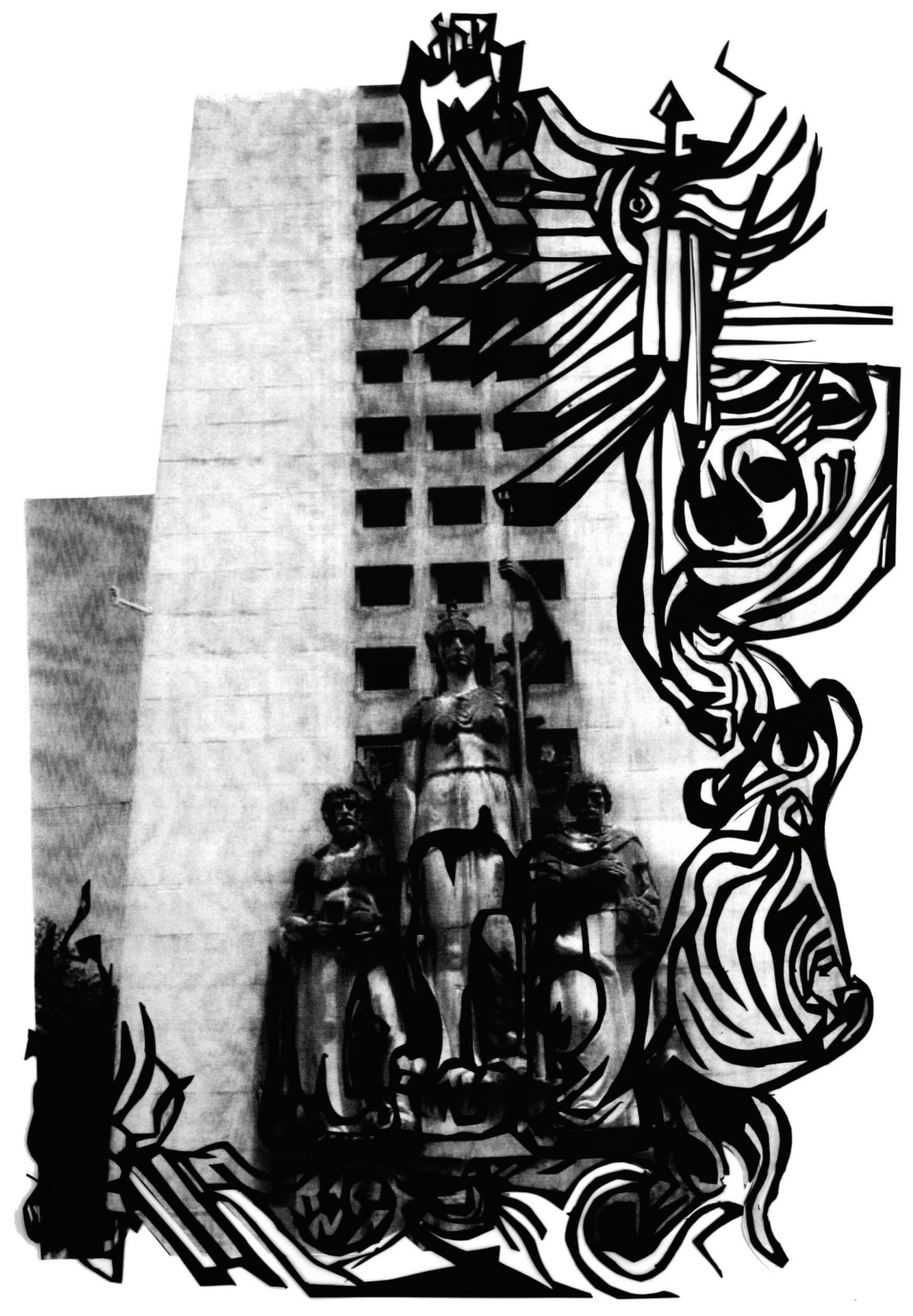



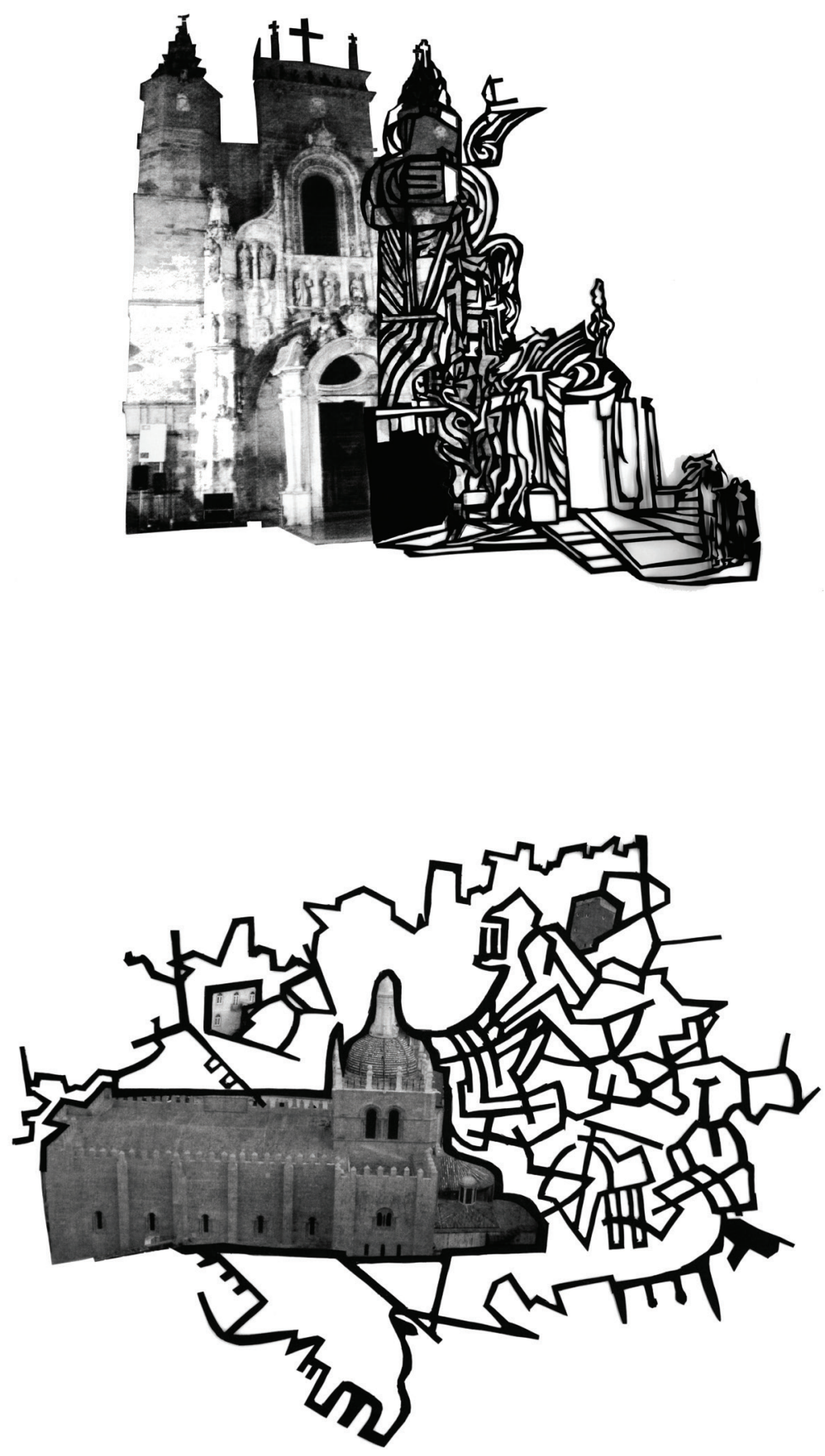

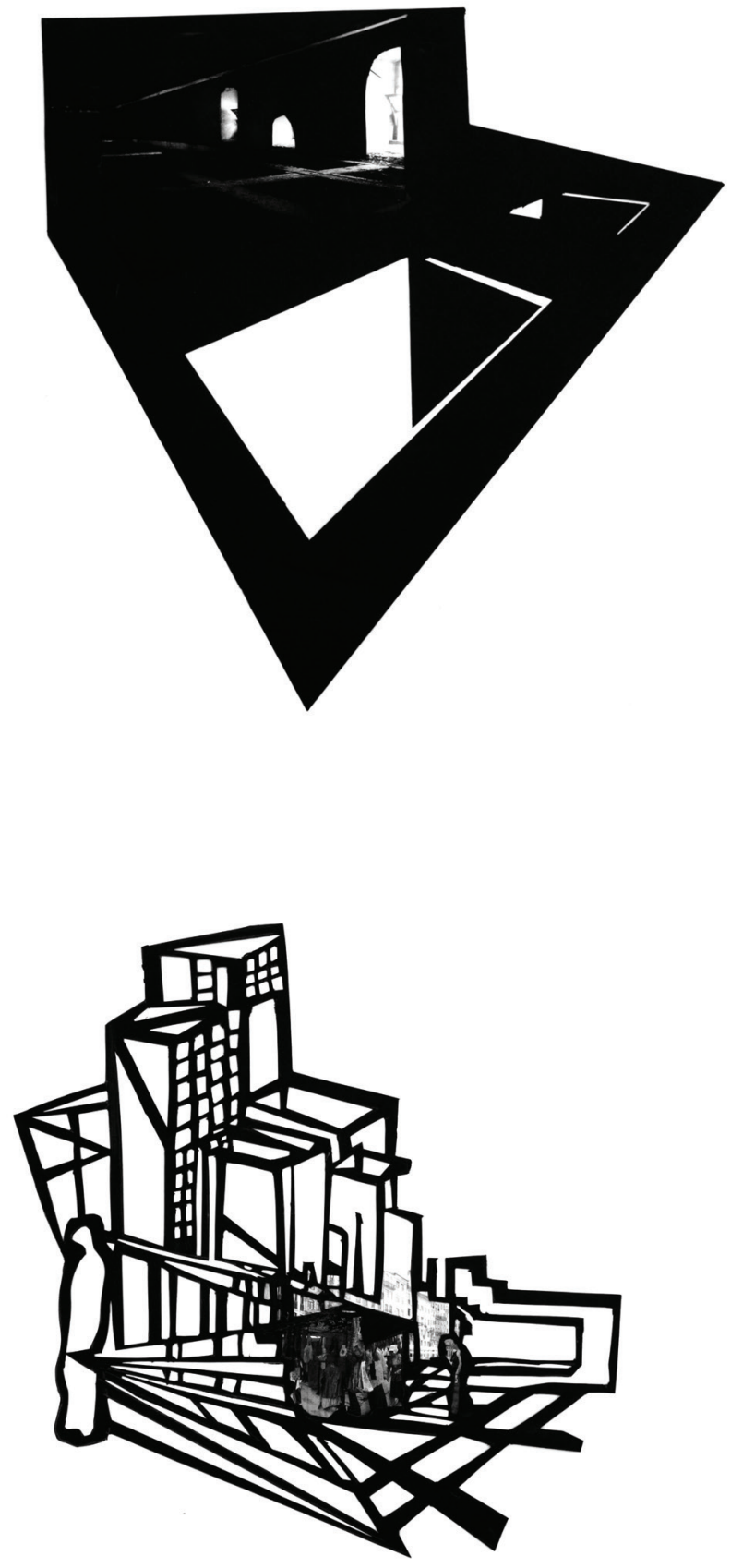


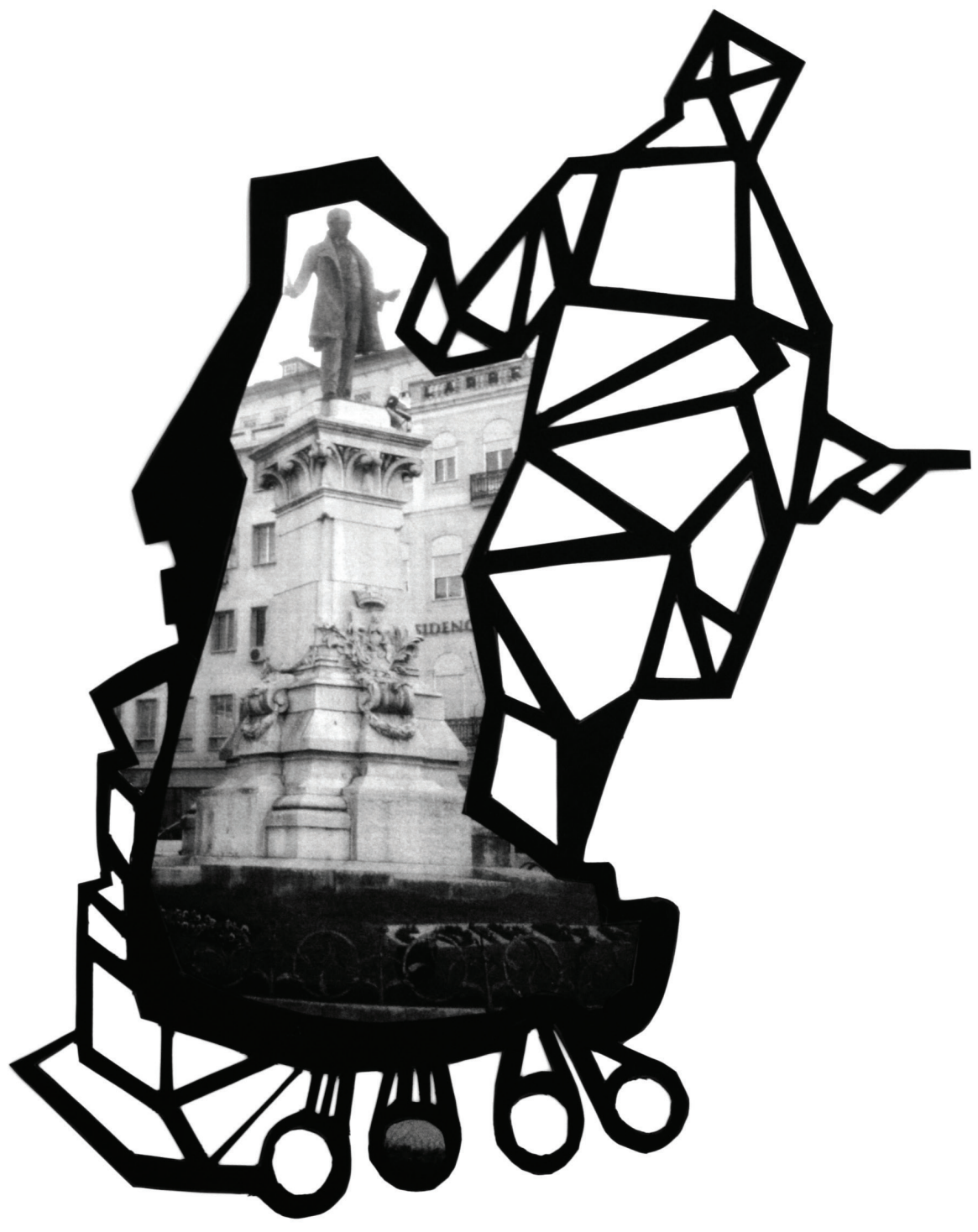



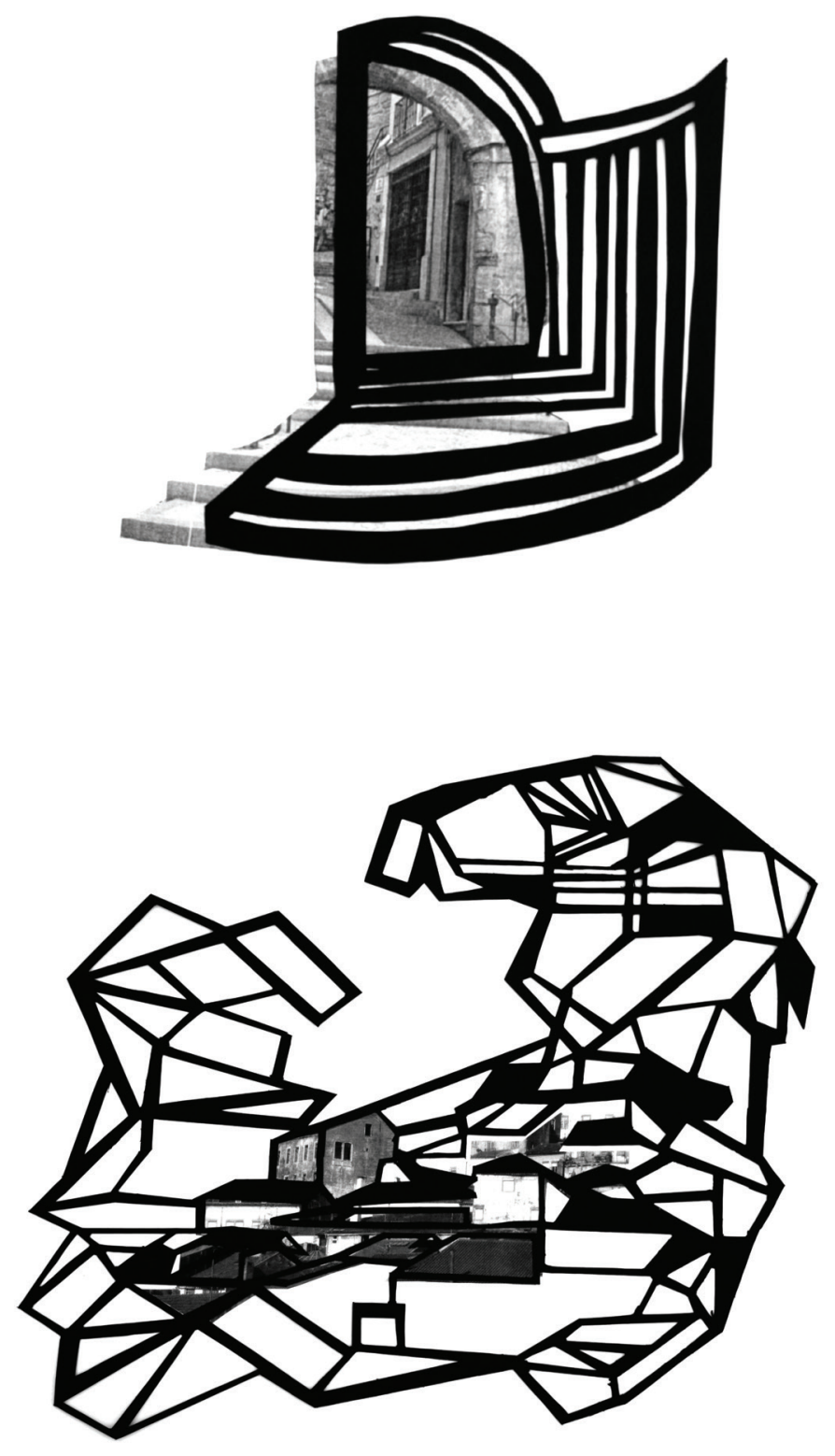

119 

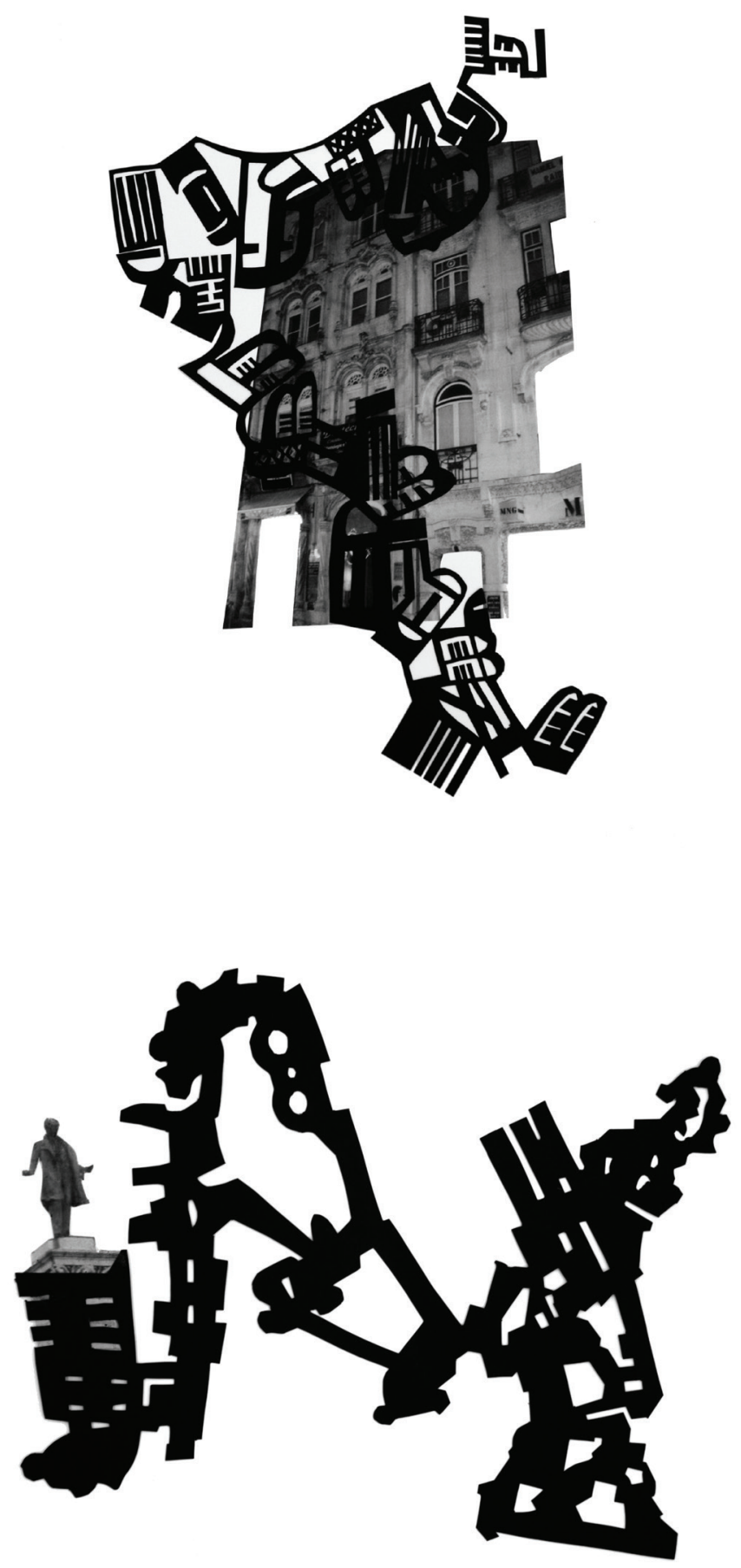

Filipa Oliveira, João Miguel Negrão 

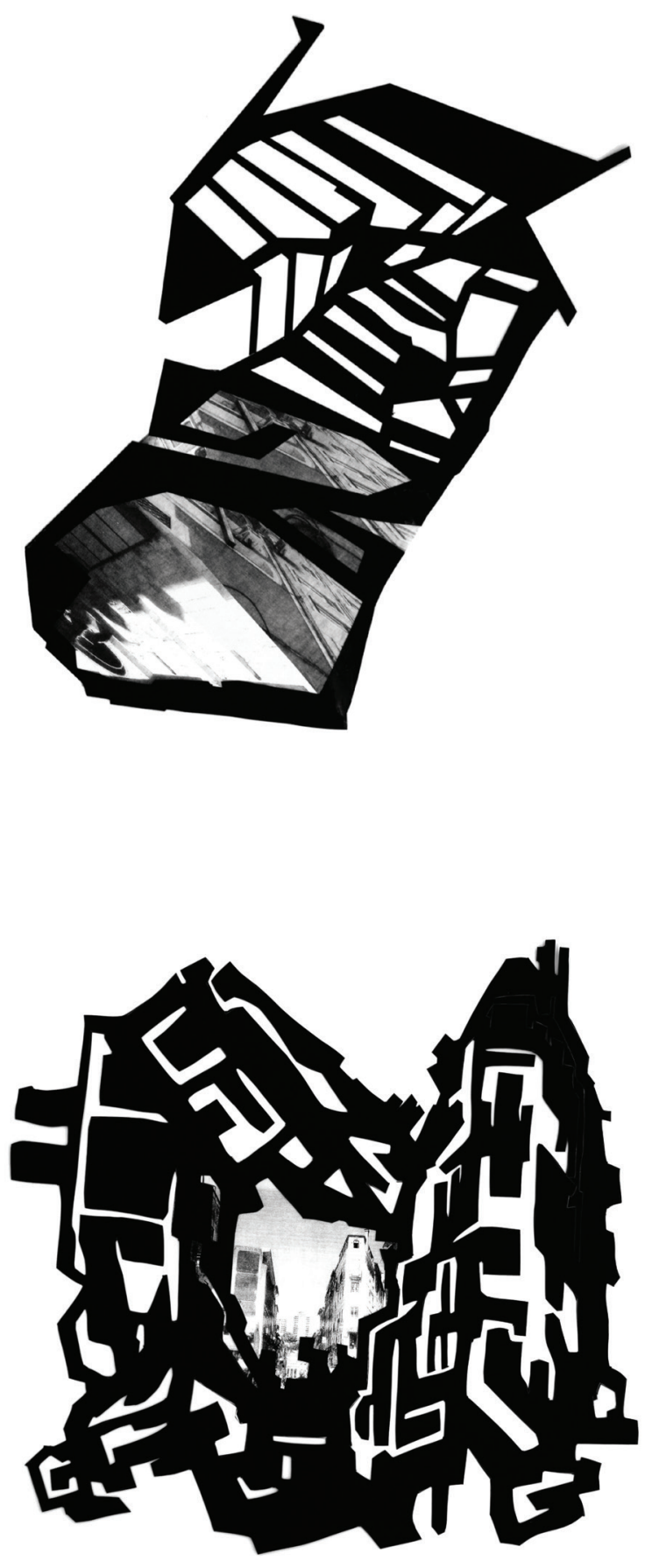

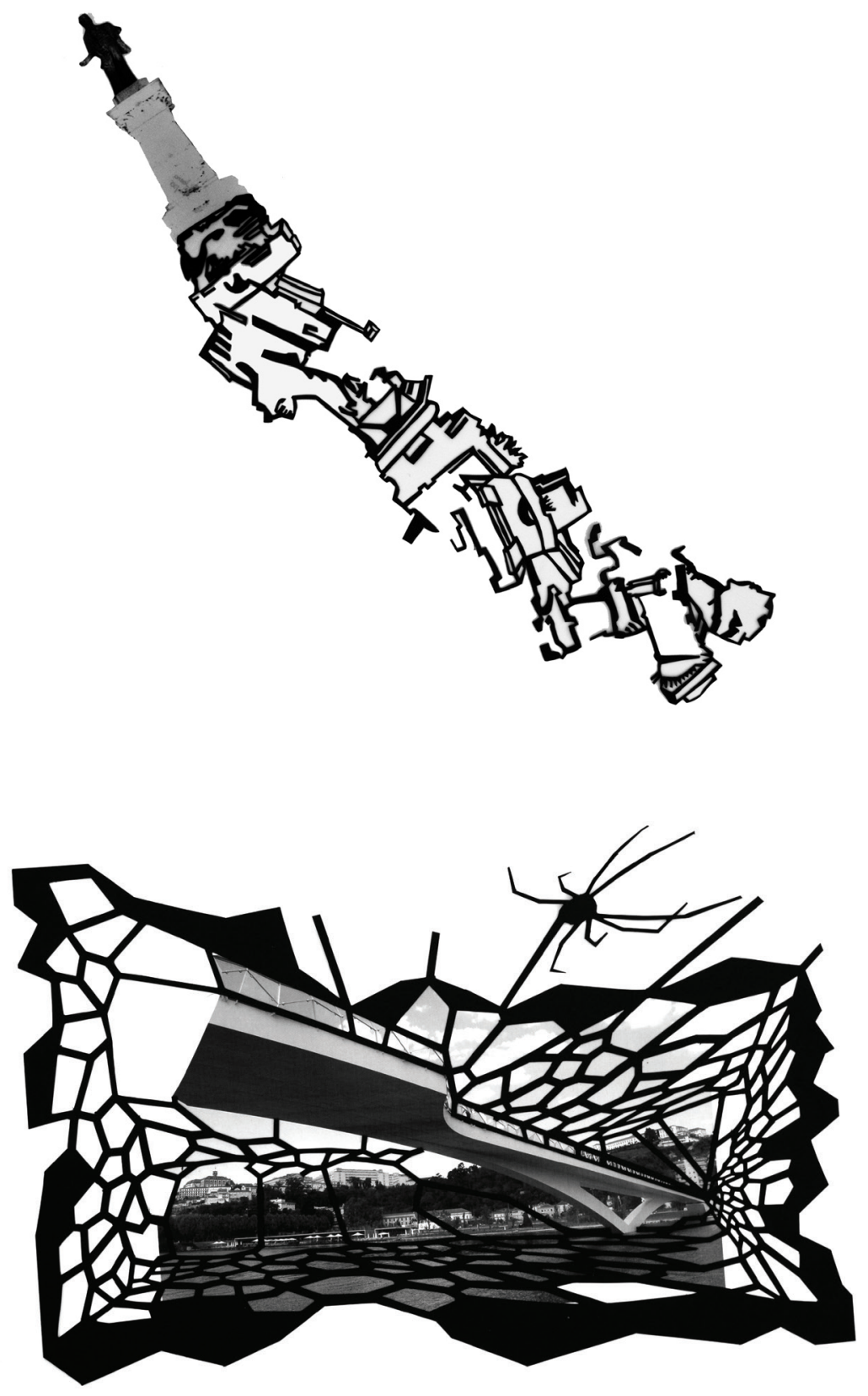

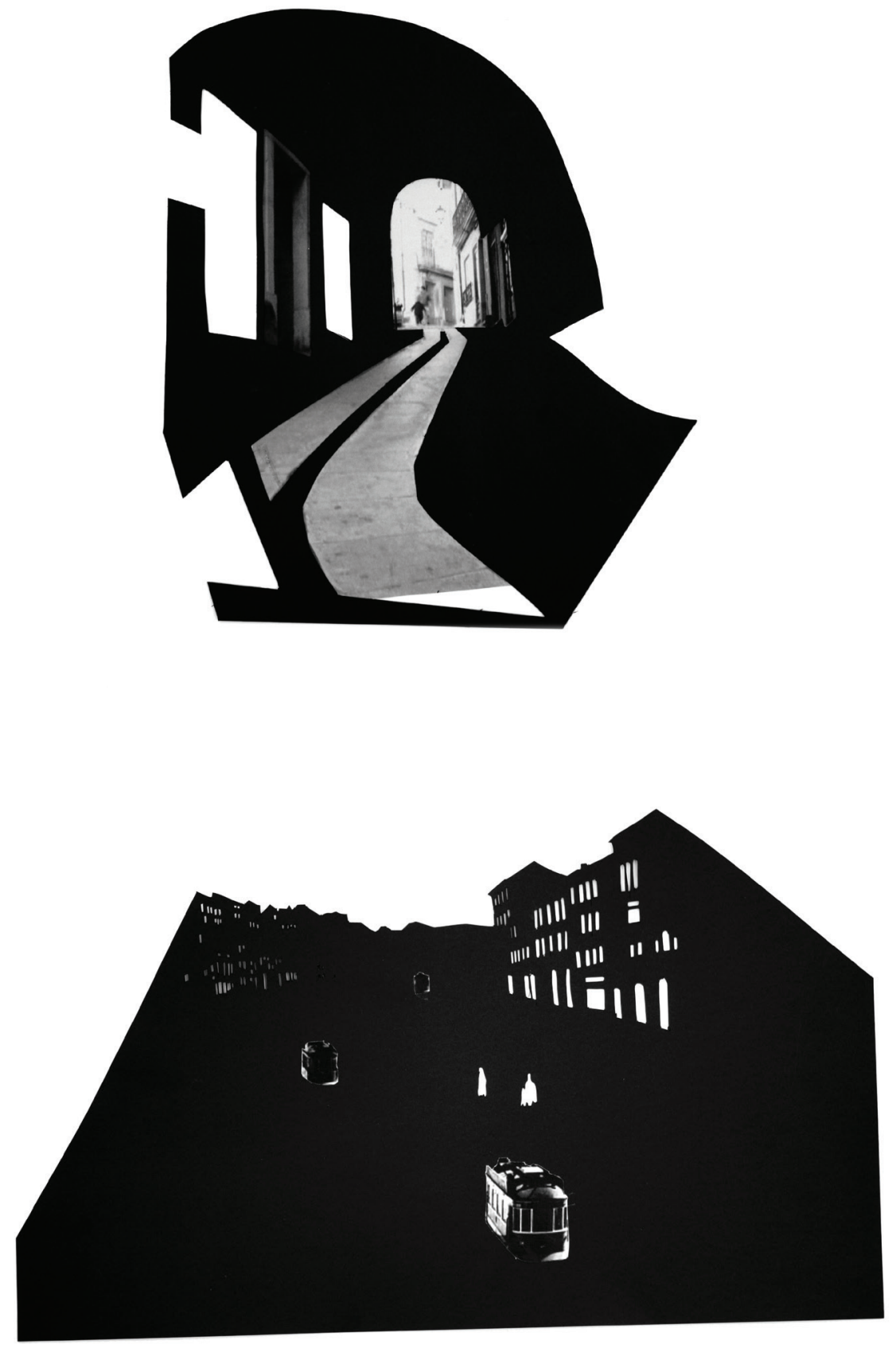

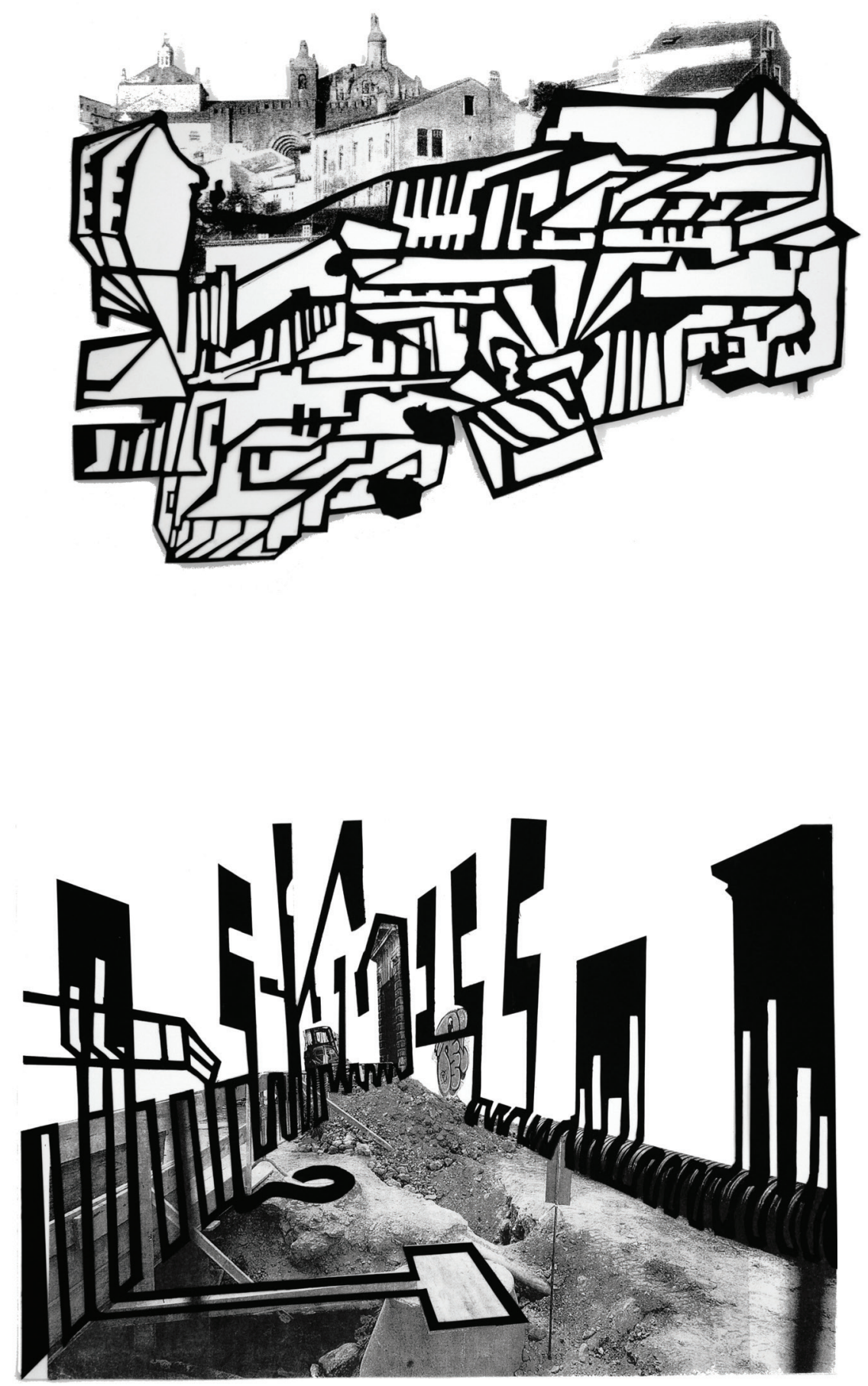

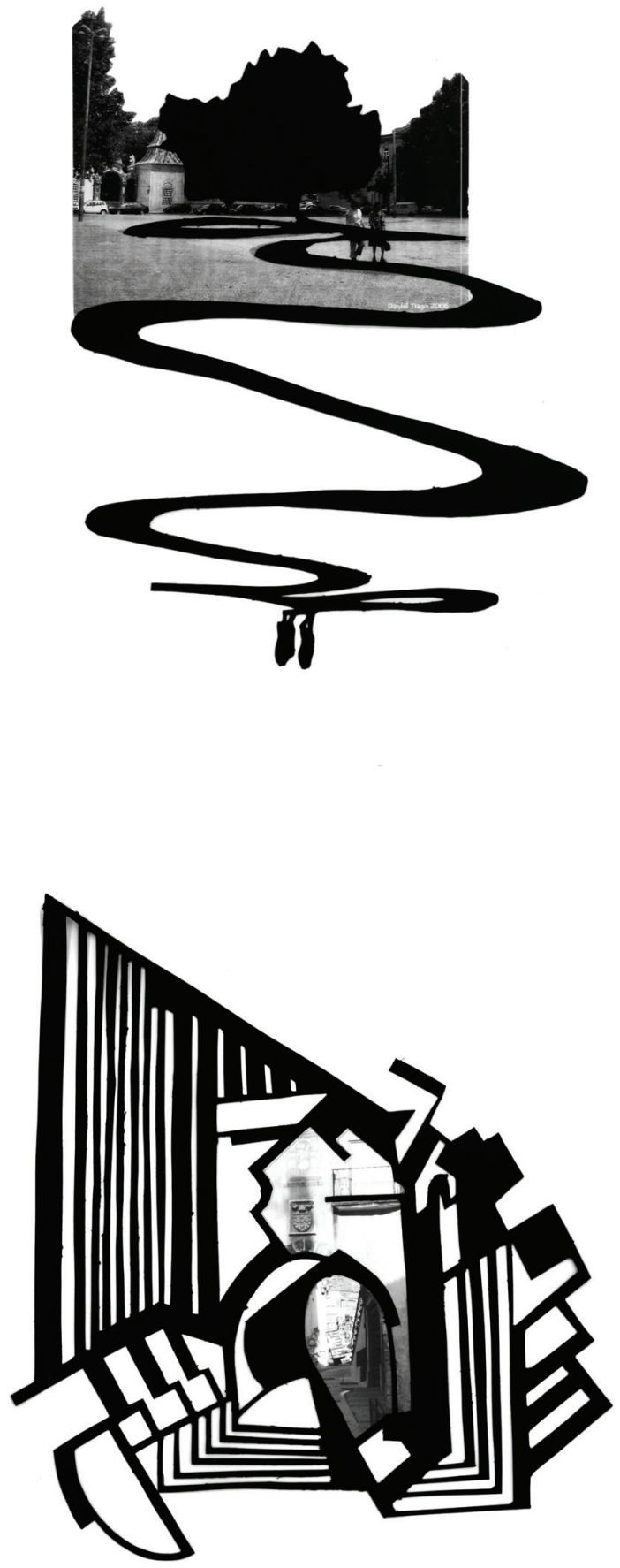

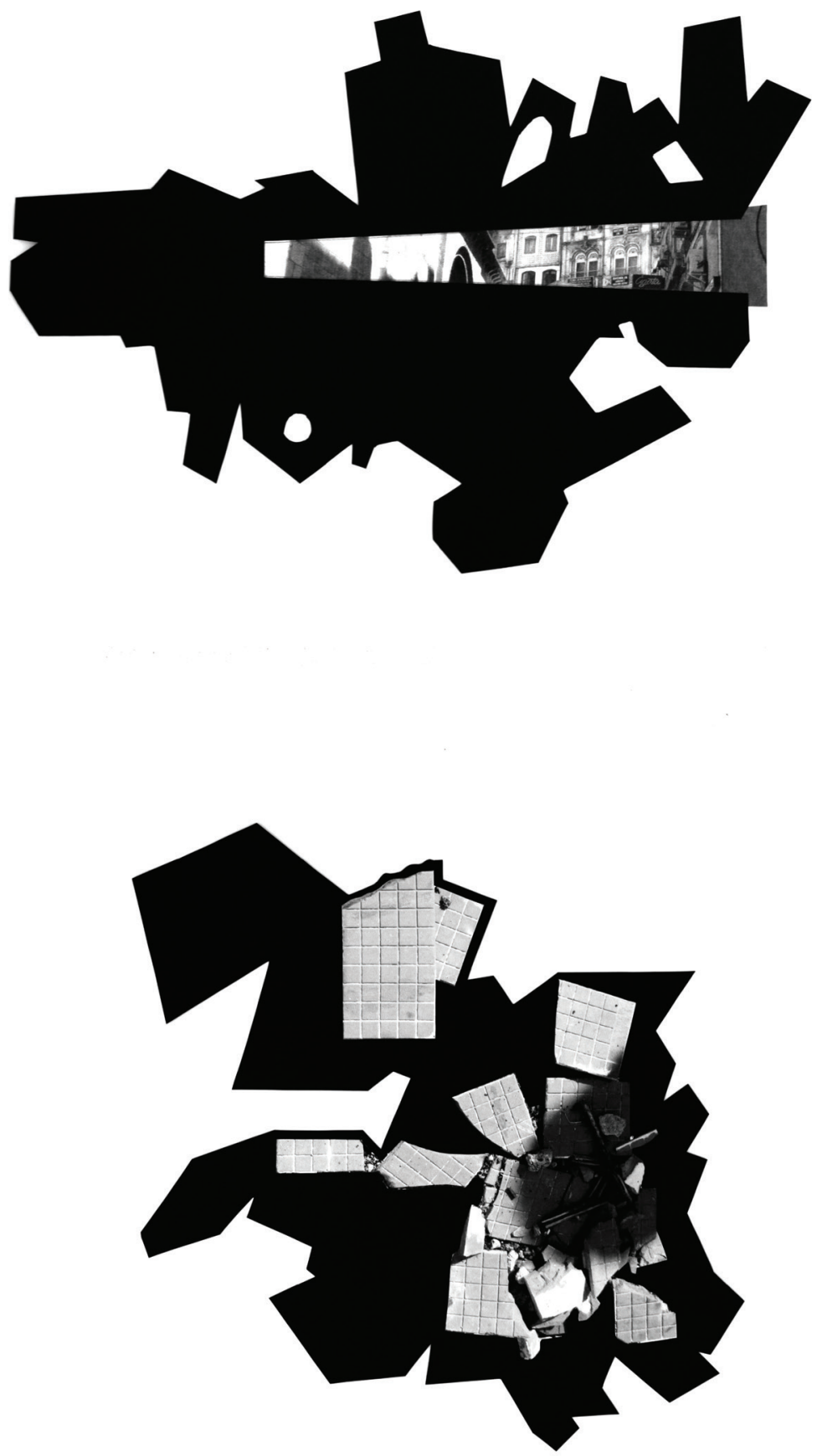

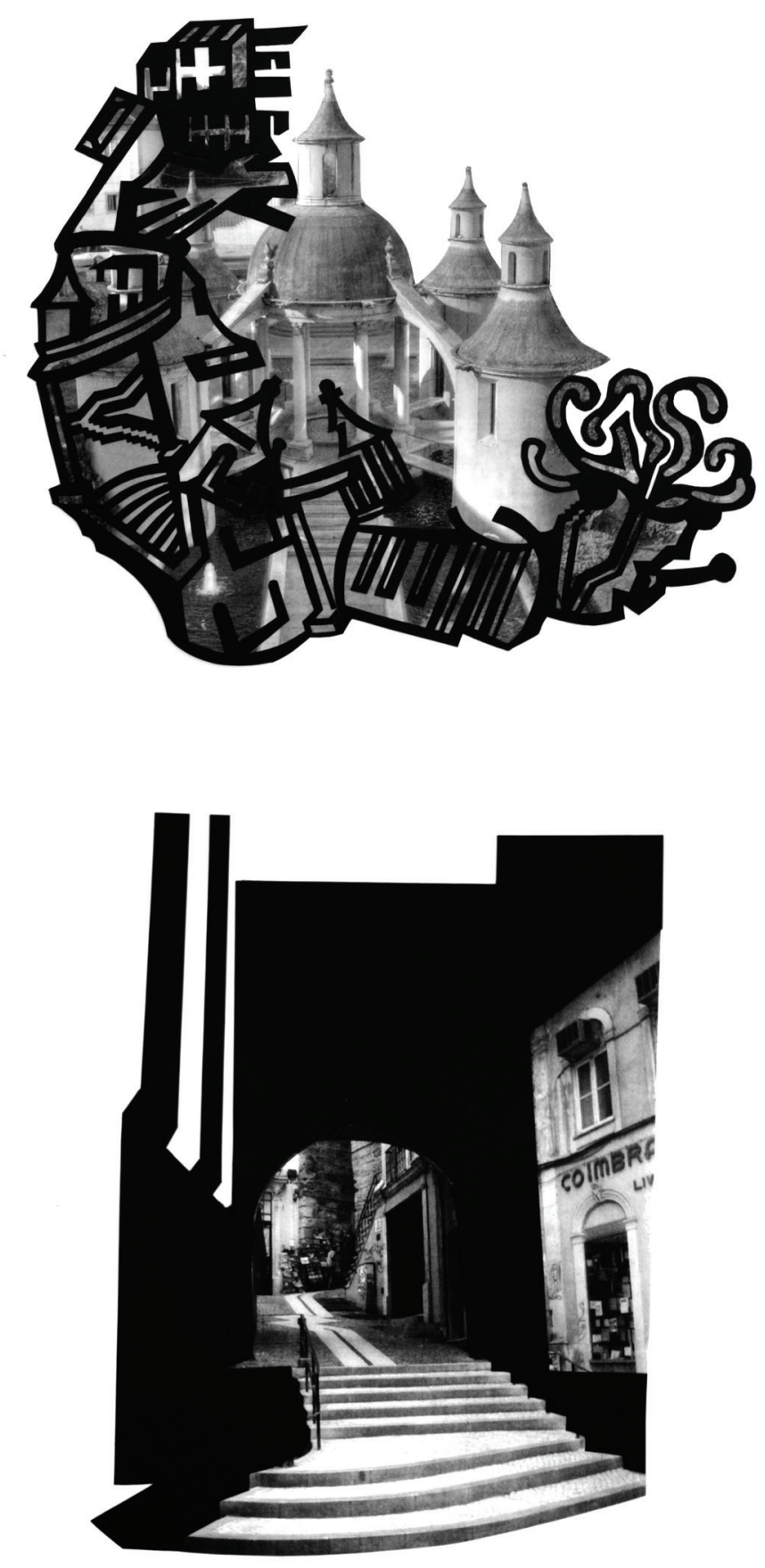

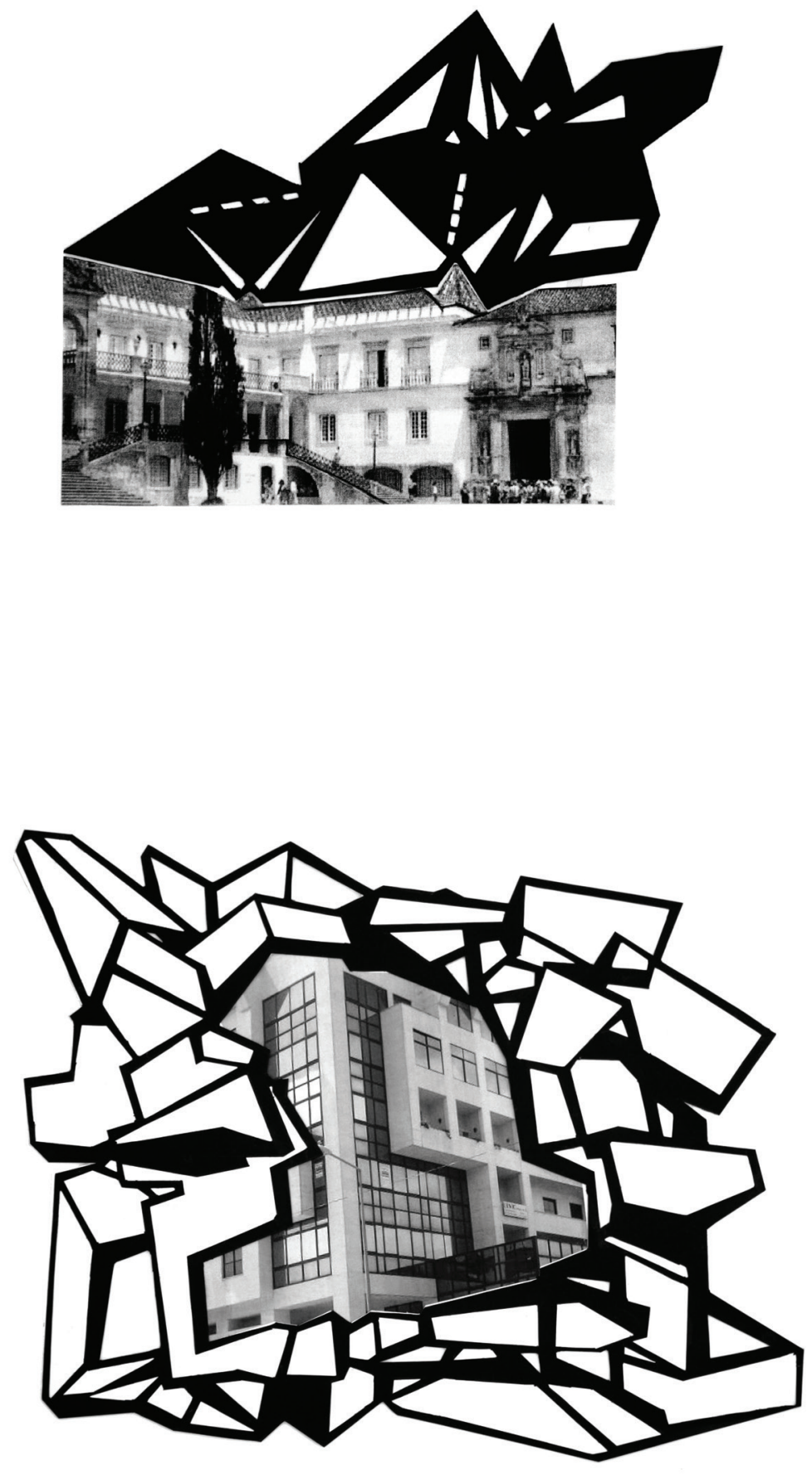

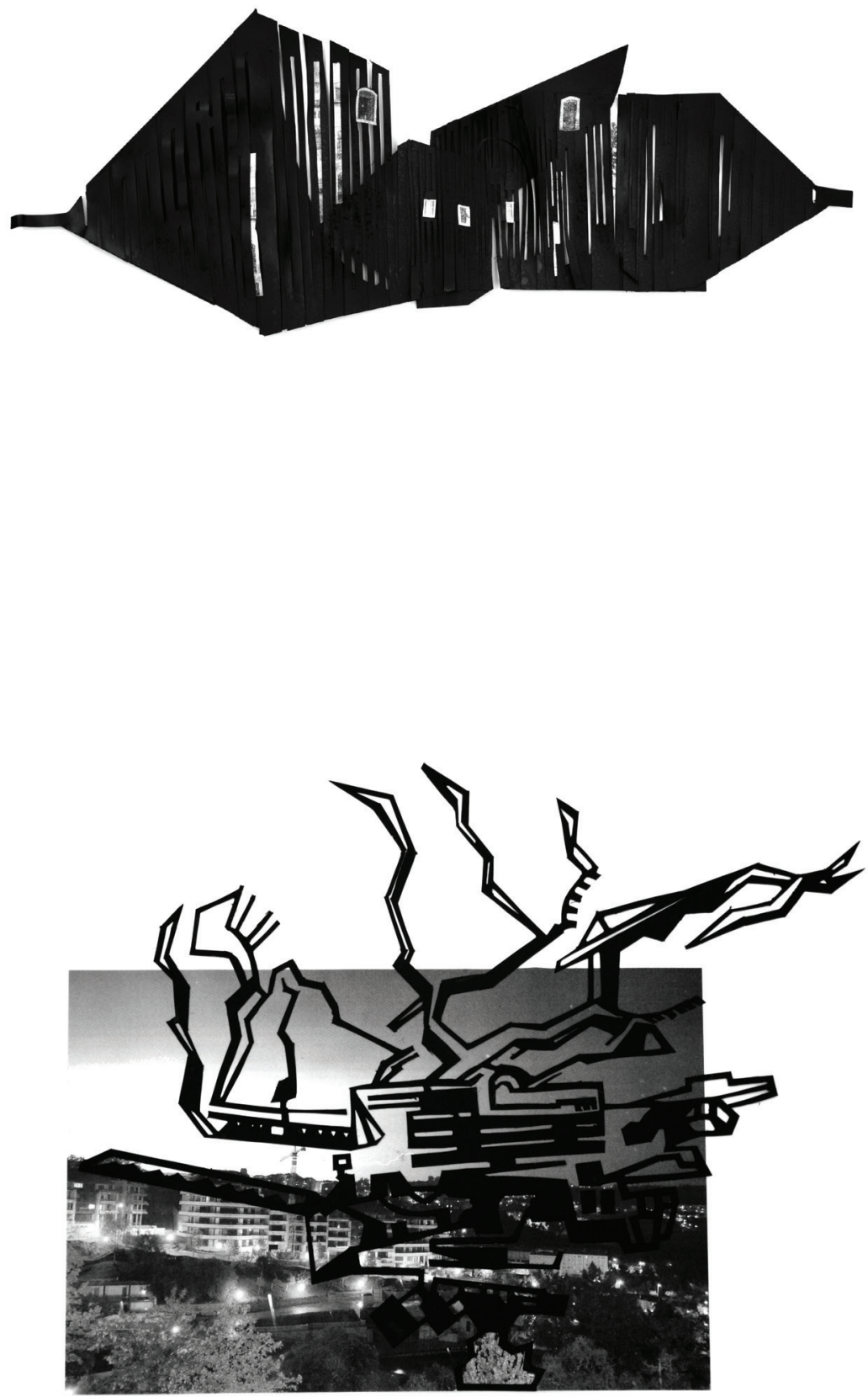

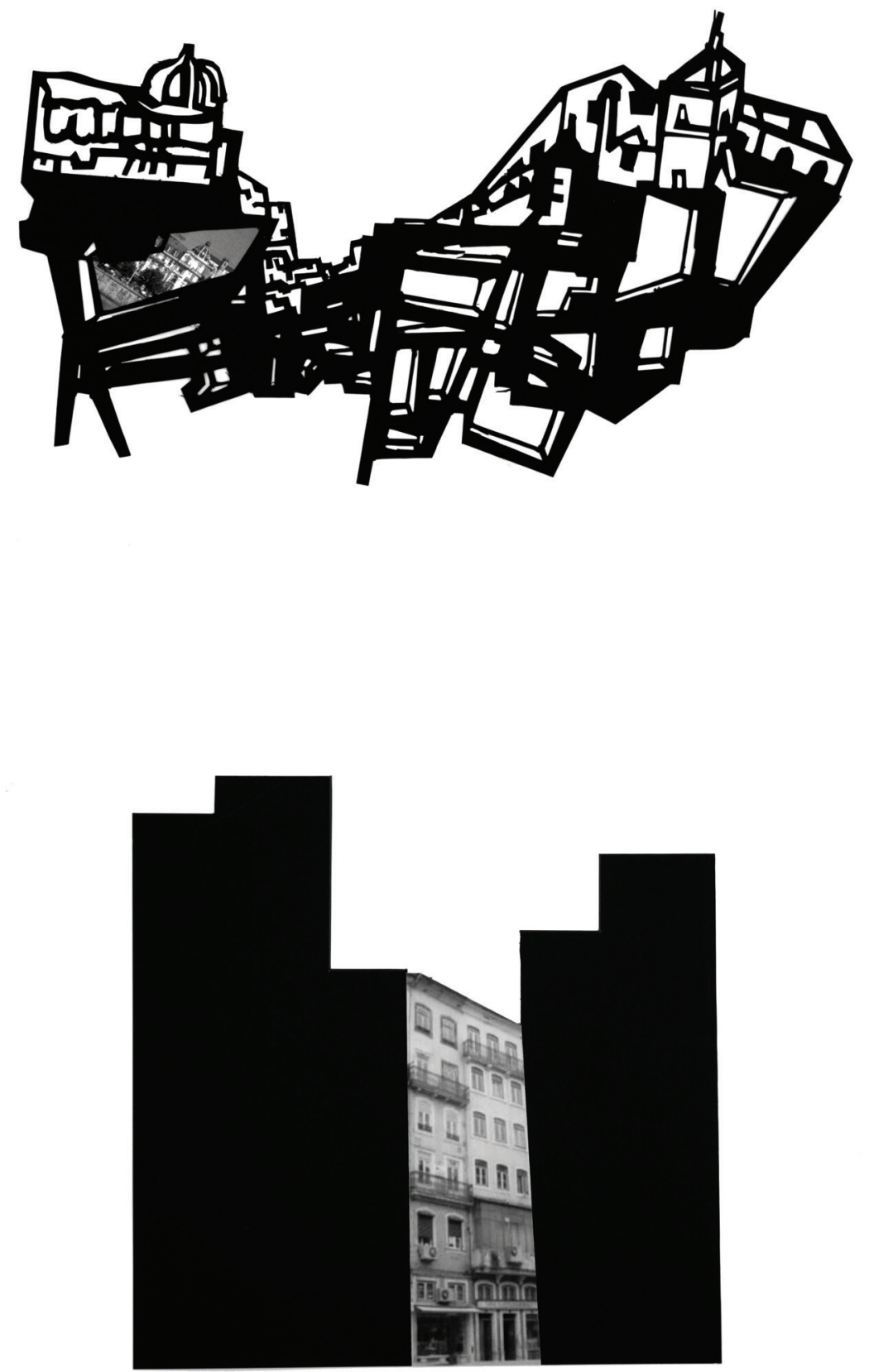


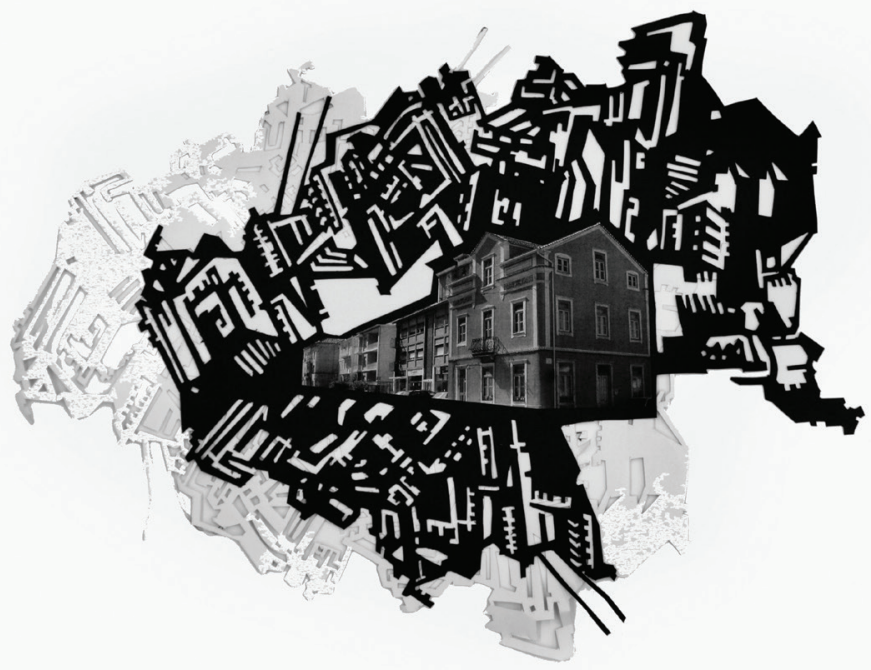

131

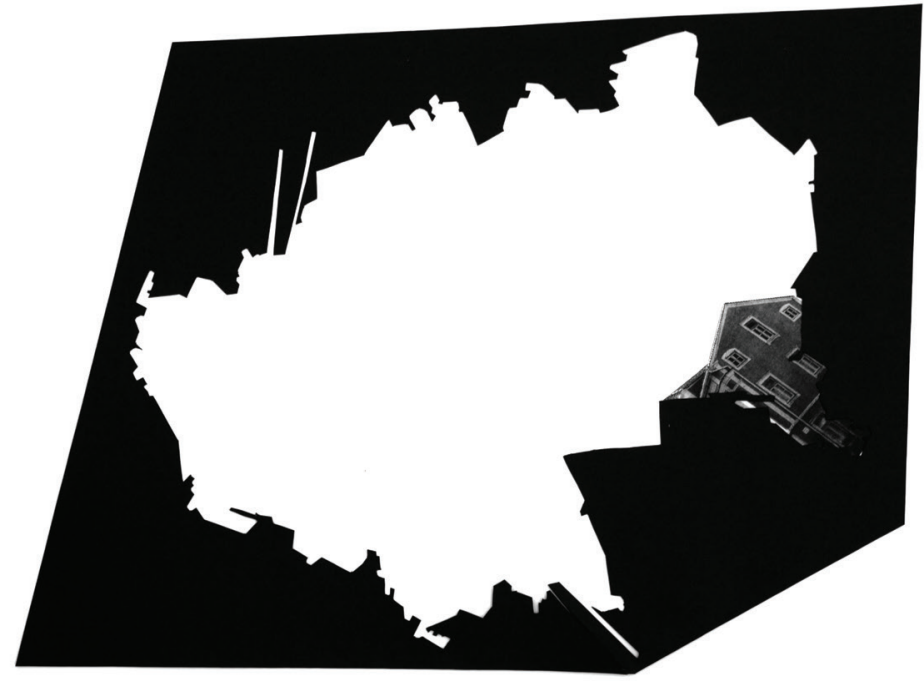


(Página deixada propositadamente em branco) 


\section{O MUNDO EM AMARELO}

Tendo o Sol como ponto de partida, os trabalhos dos alunos que resultaram na exposição "O Mundo em Amarelo" articulam as linguagens da arquitectura, enquanto criadora de formas e transformadora dos espaços, com a plasticidade cromática.

Aqui o cromatismo, mais do que aplicado às formas arquitectónicas, é gerador de atmosferas. A organicidade das formas e das cores que cobre as paredes da sala sugere a possibilidade de um espaço plasmático onde todas as formas seráo potencialmente possíveis. Nestes trabalhos, os alunos criaram composiçóes libertas de limites ortogonais. Cada trabalho individual contribui assim para uma relação orgânica com um todo que contamina as paredes, onde as formas são lidas enquanto etapas de um constante processo de transformação, mutação.

Paralelamente a estes trabalhos de explosão cromática e formal, os alunos criaram pequenos volumes arquitectónicos brancos, imaginando e materializando a sua sombra projectada. Aqui o jogo consiste sobretudo nas relaçóes entre objecto e a sua sombra, investindo nas surpresas criadas ao autonomizar objecto e sombra, encarando estas sombras como lugar de citação, sugestão, articulação de múltiplas realidades. 
(Página deixada propositadamente em branco) 

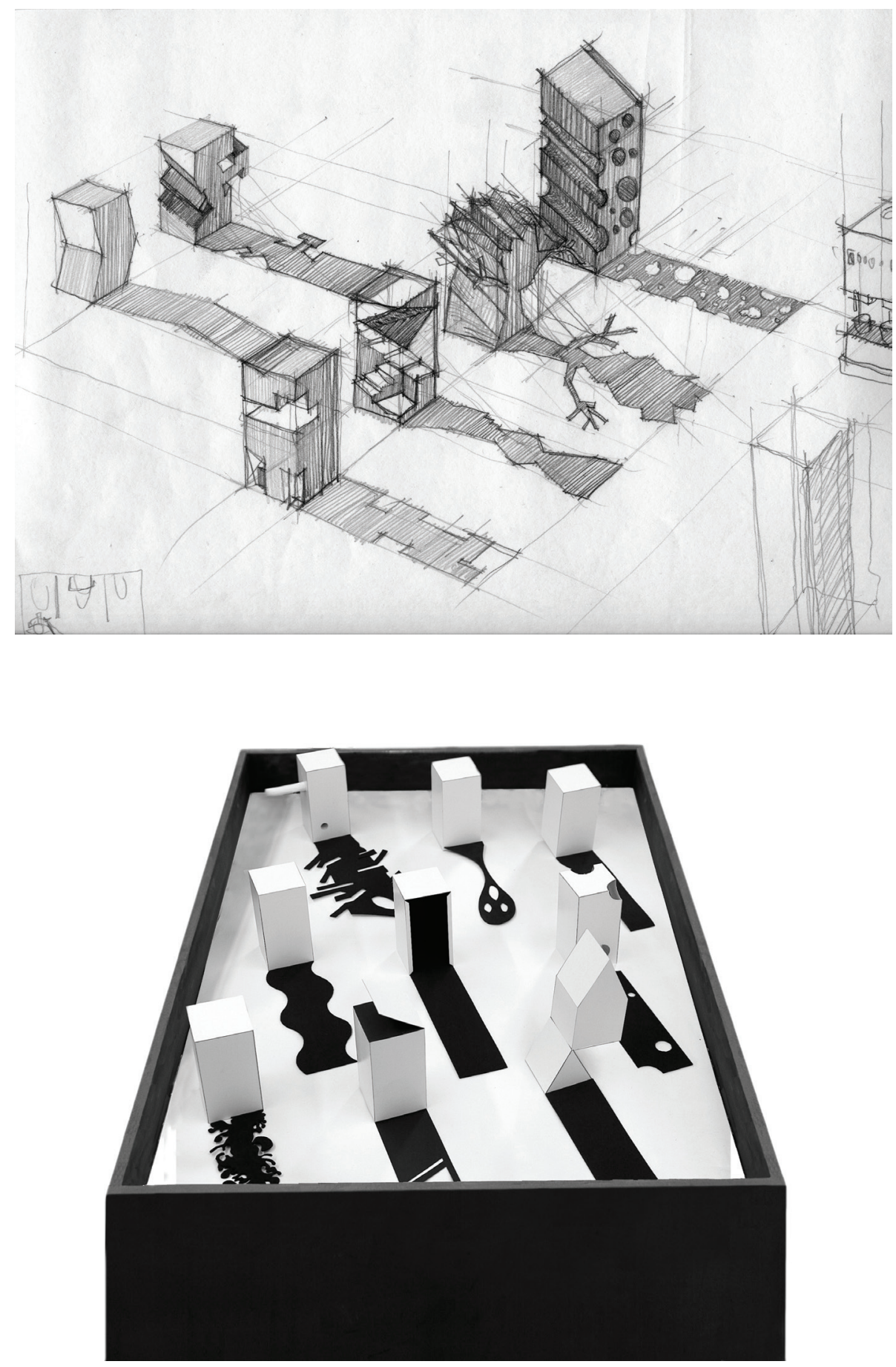


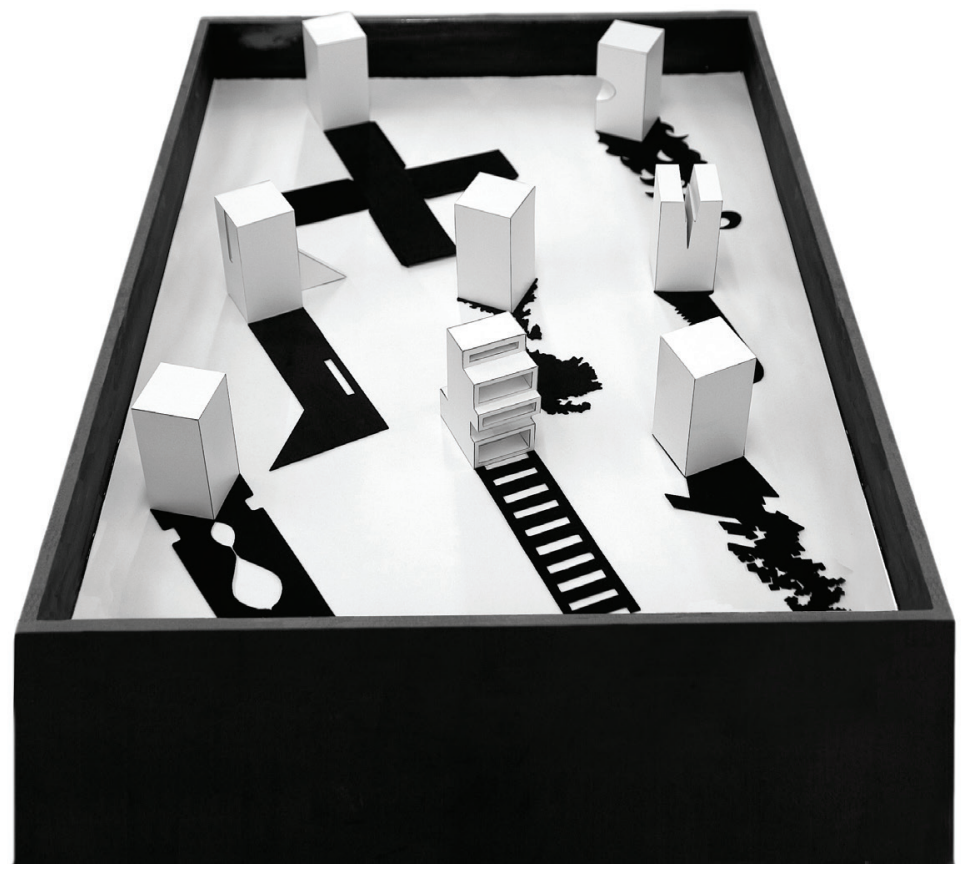


䦨 



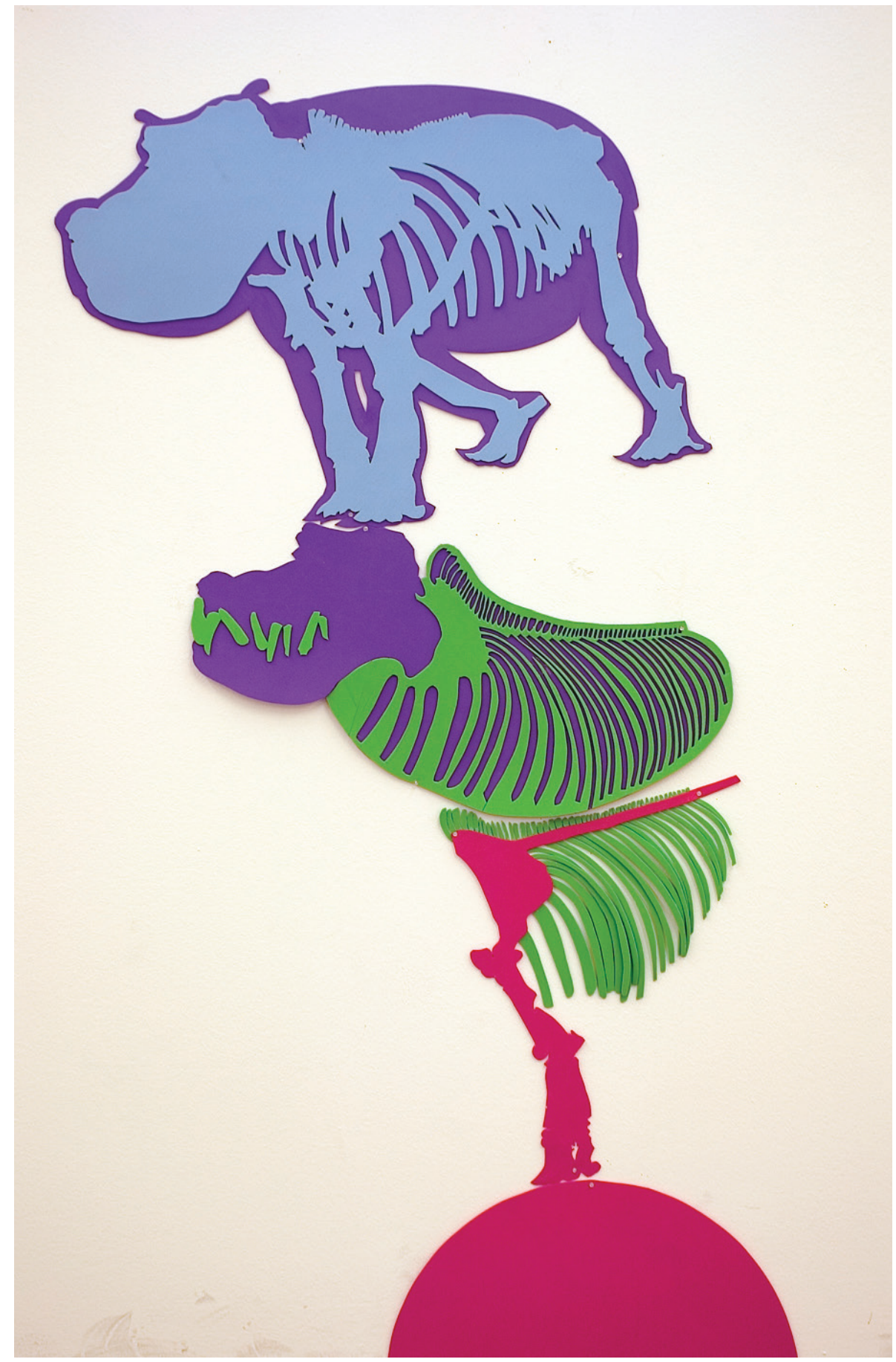




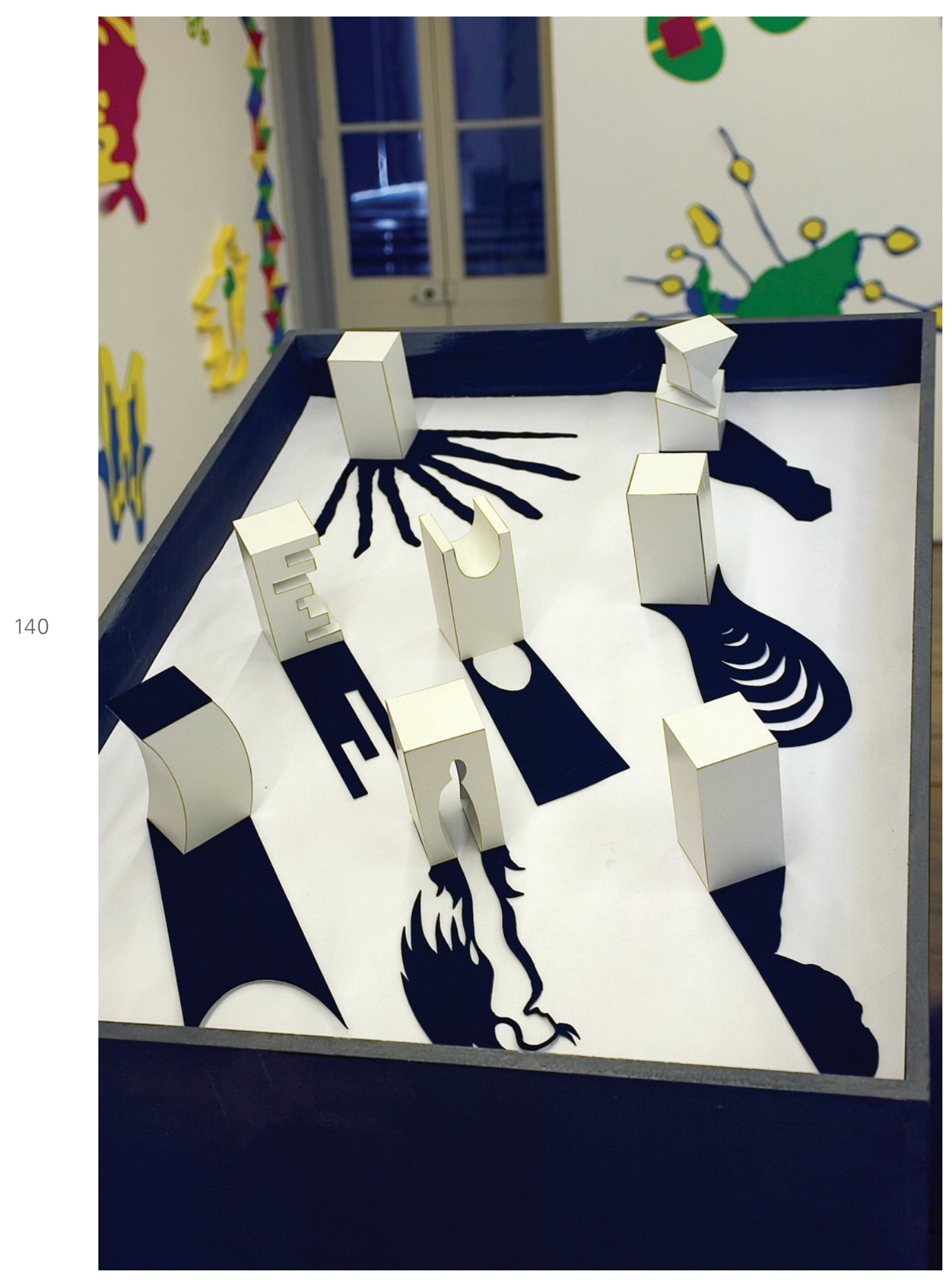




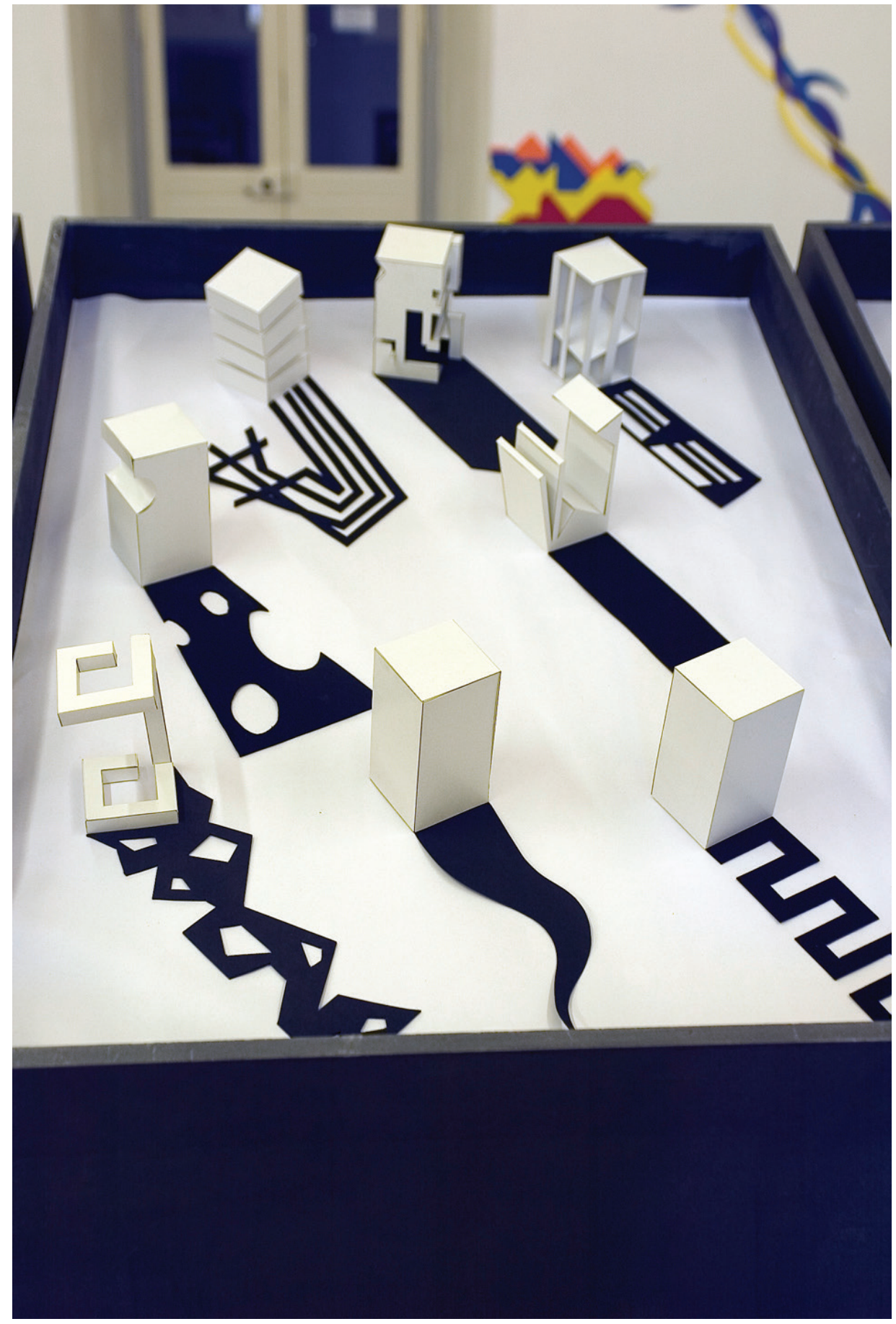



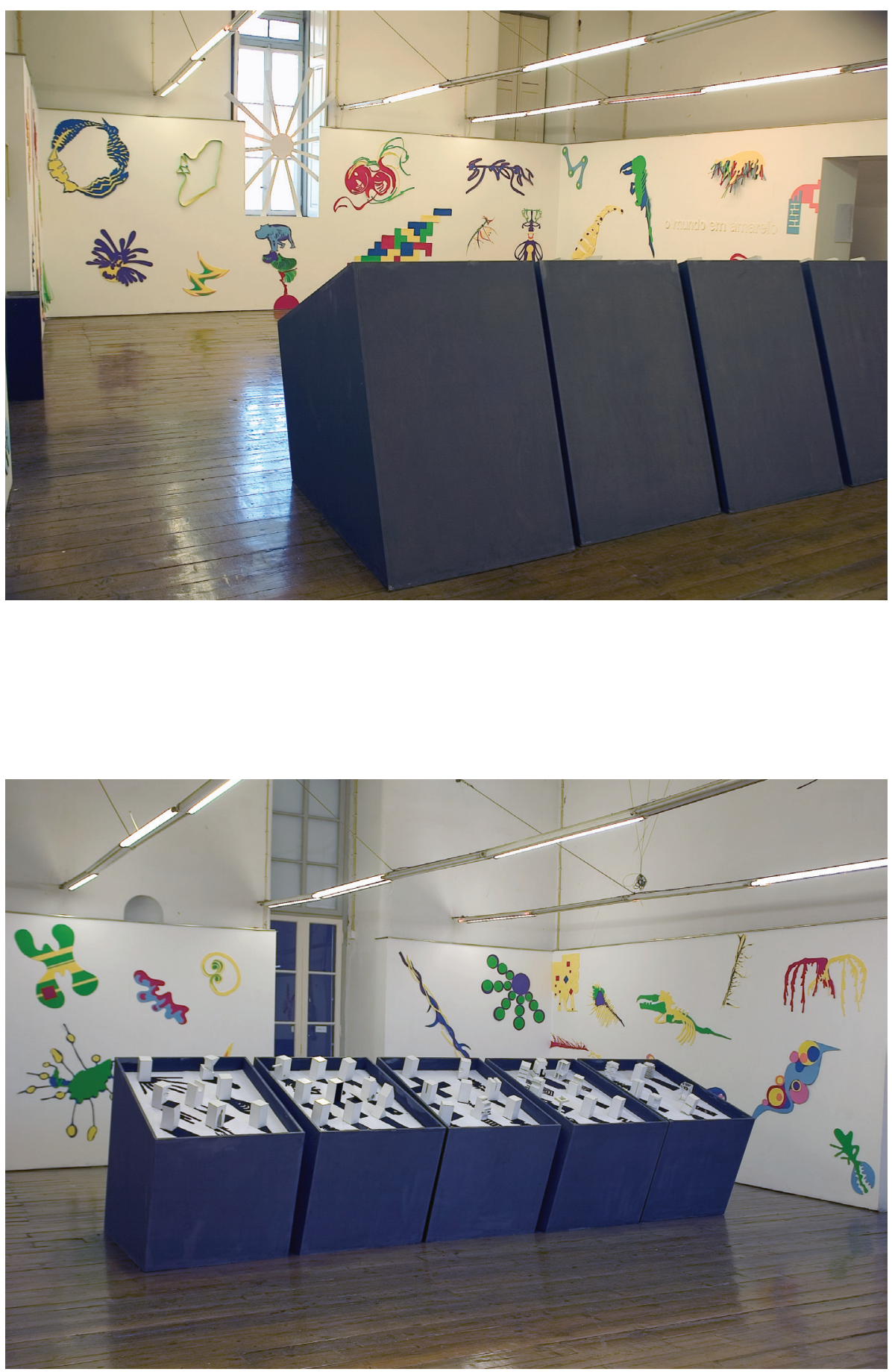

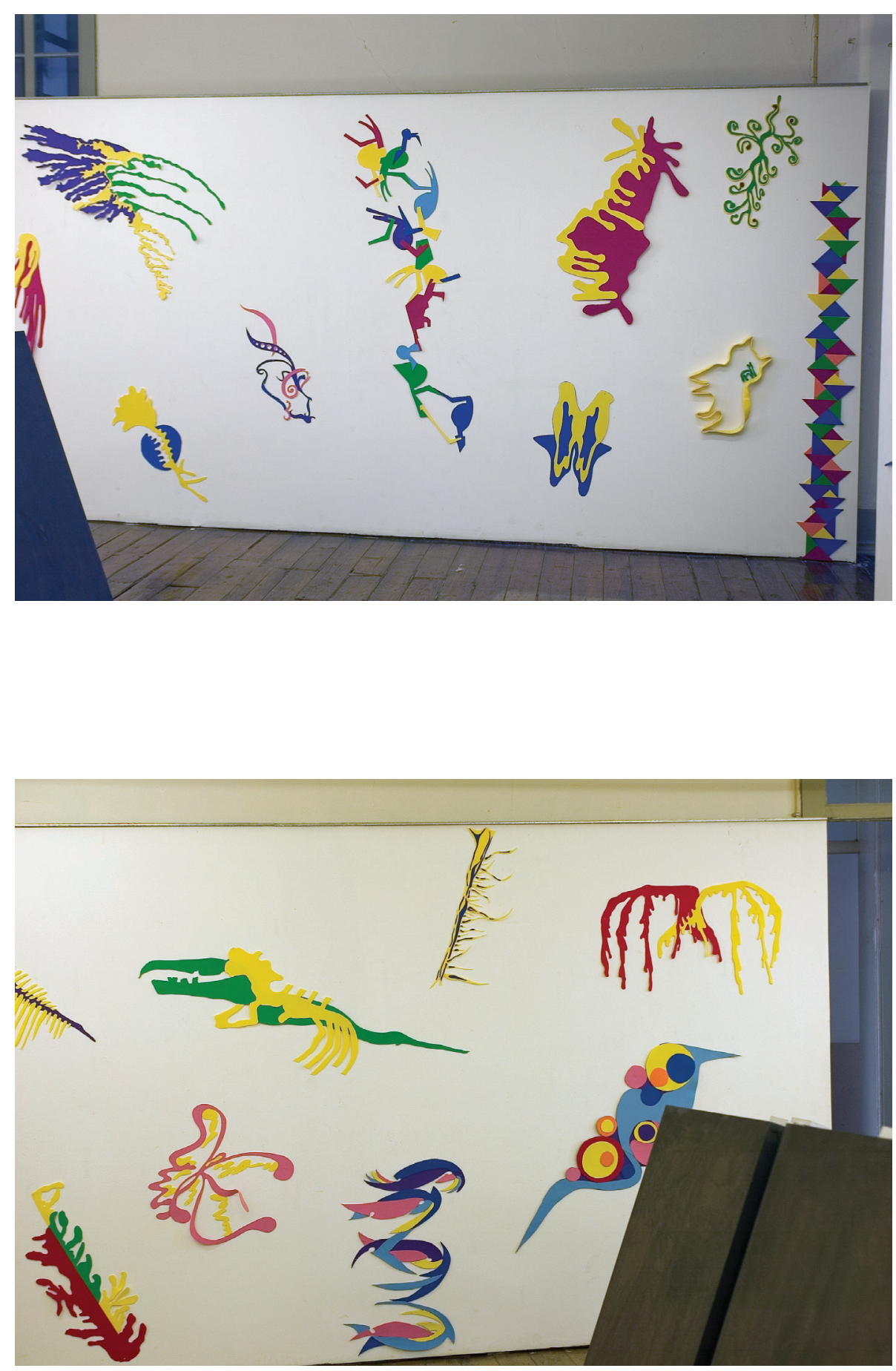

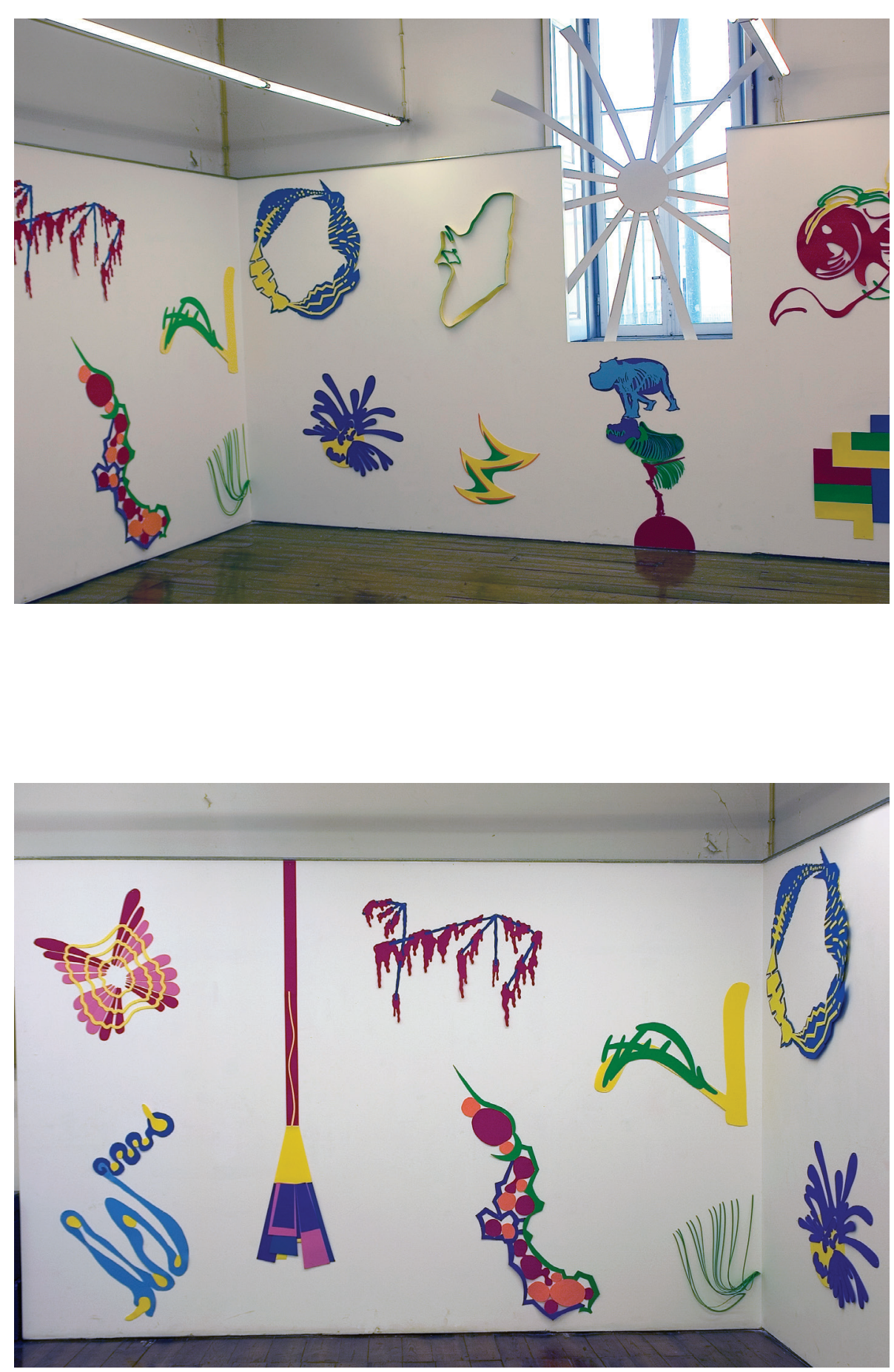

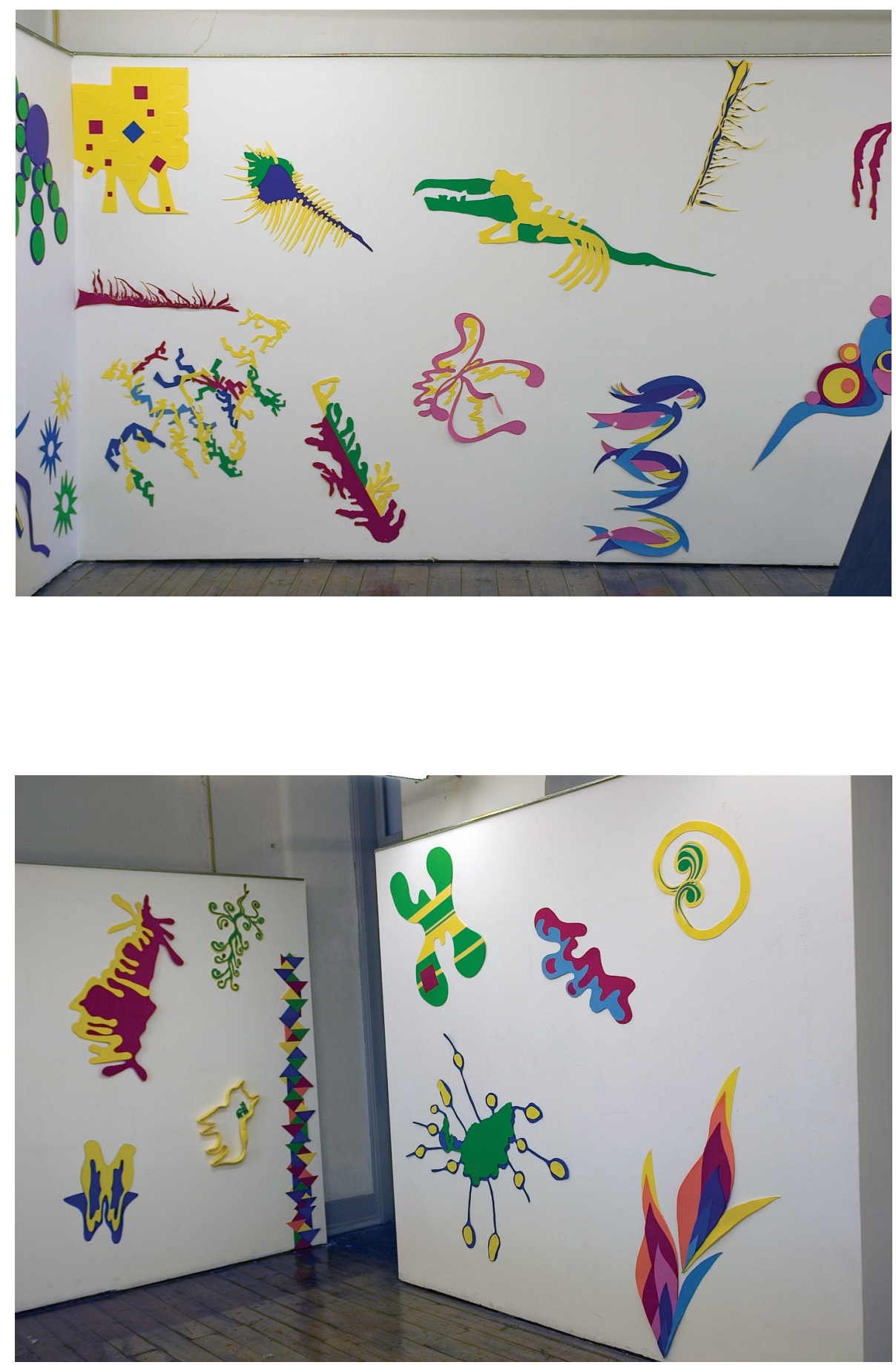
(Página deixada propositadamente em branco) 


\section{WALKING ON THE MOON}

Numa das exposiçóes que fizemos no Círculo de Artes Plásticas de Coimbra com os trabalhos dos alunos de Desenho II, os exercícios encontravam uma relação particular com o título que démos a estas exposiçôes que fizémos em dois anos consecutivos.

Tendo como suporte círculos das mesmas dimensões, estes círculos/planetas, eram colonizados por quaisquer materiais, quaisquer sugestôes temáticas ou linguagens compositivas.

Constante era o círculo e a sua dimensão. E estes círculos por vezes surgiram antropomorfizados em rostos como sendo espelhos que reinventam personagens, ou, frequentemente, conscientes das suas potencialidades na gestação de composiçôes centrífugas e centrípetas. Suportes, janelas, ou mesmo buracos, para outras realidades ou matérias.

Confrontados com estes trabalhos surgiam grandes ampliaçôes de pormenores de desenhos dos alunos, realizados noutros contextos, numa obsessiva relação com a forma redonda, acentuando a sugestão de óculo, de dispositivo que condiciona e, ao mesmo tempo, estimula o olhar a realidade 
(Página deixada propositadamente em branco) 


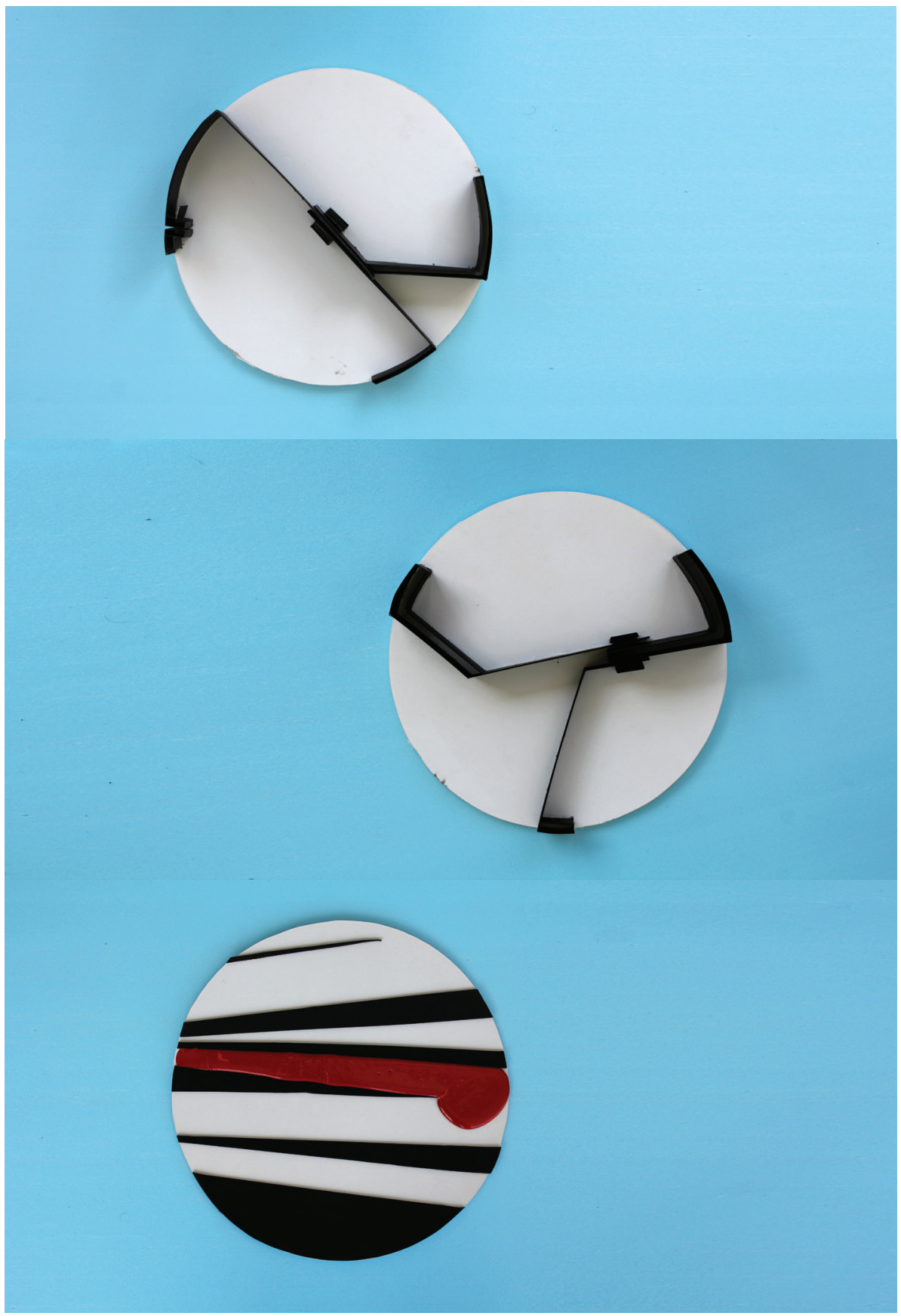




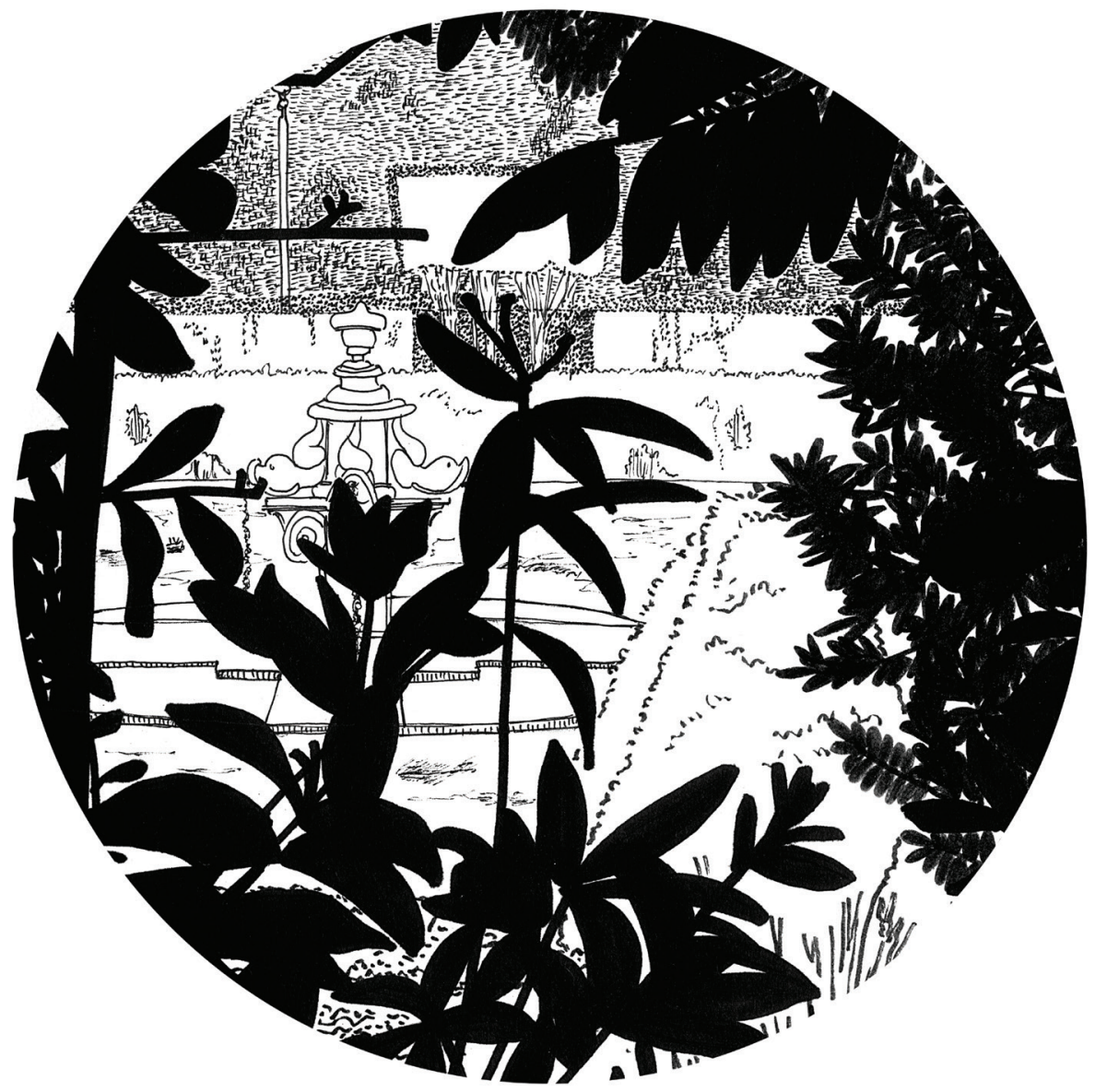




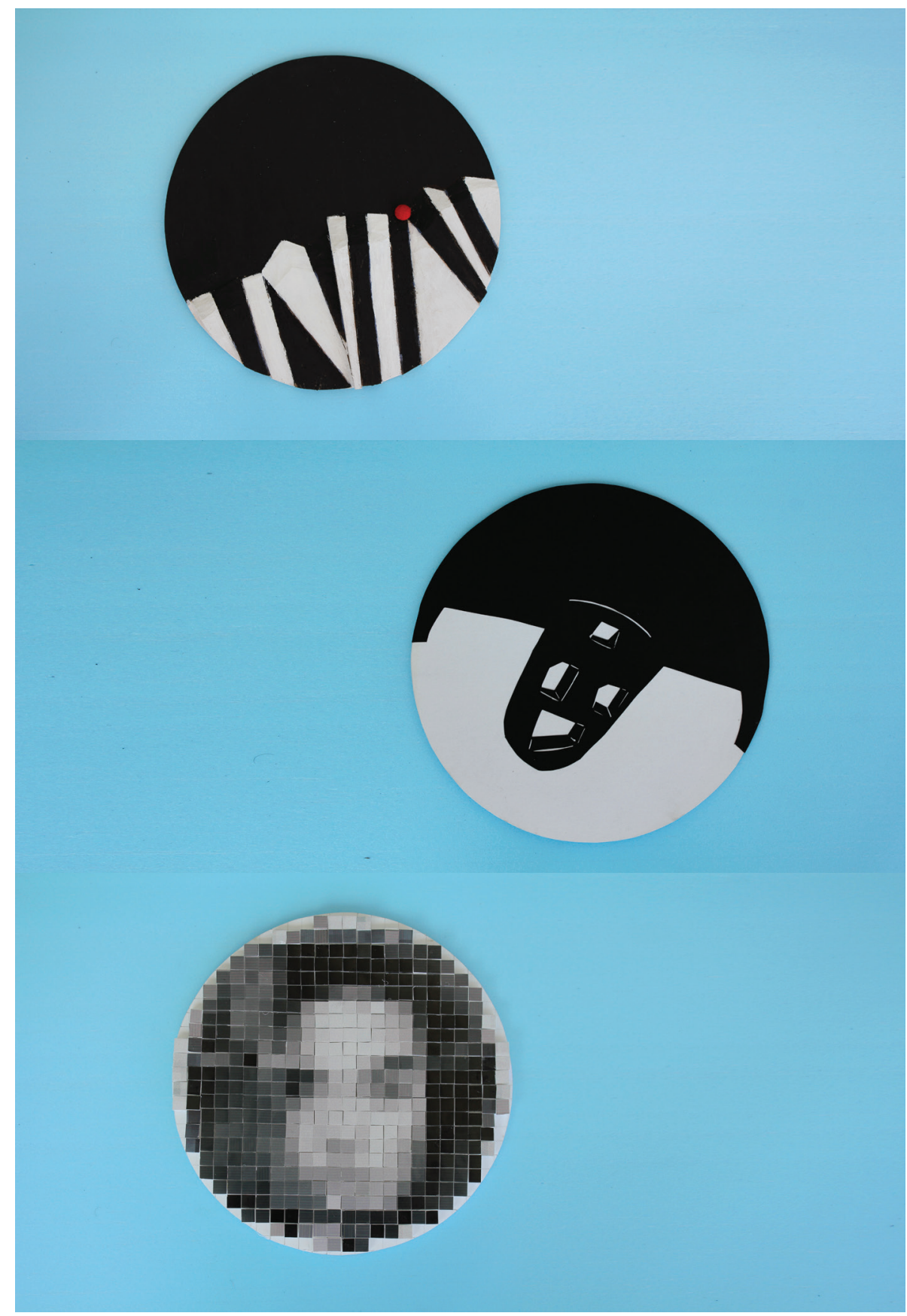



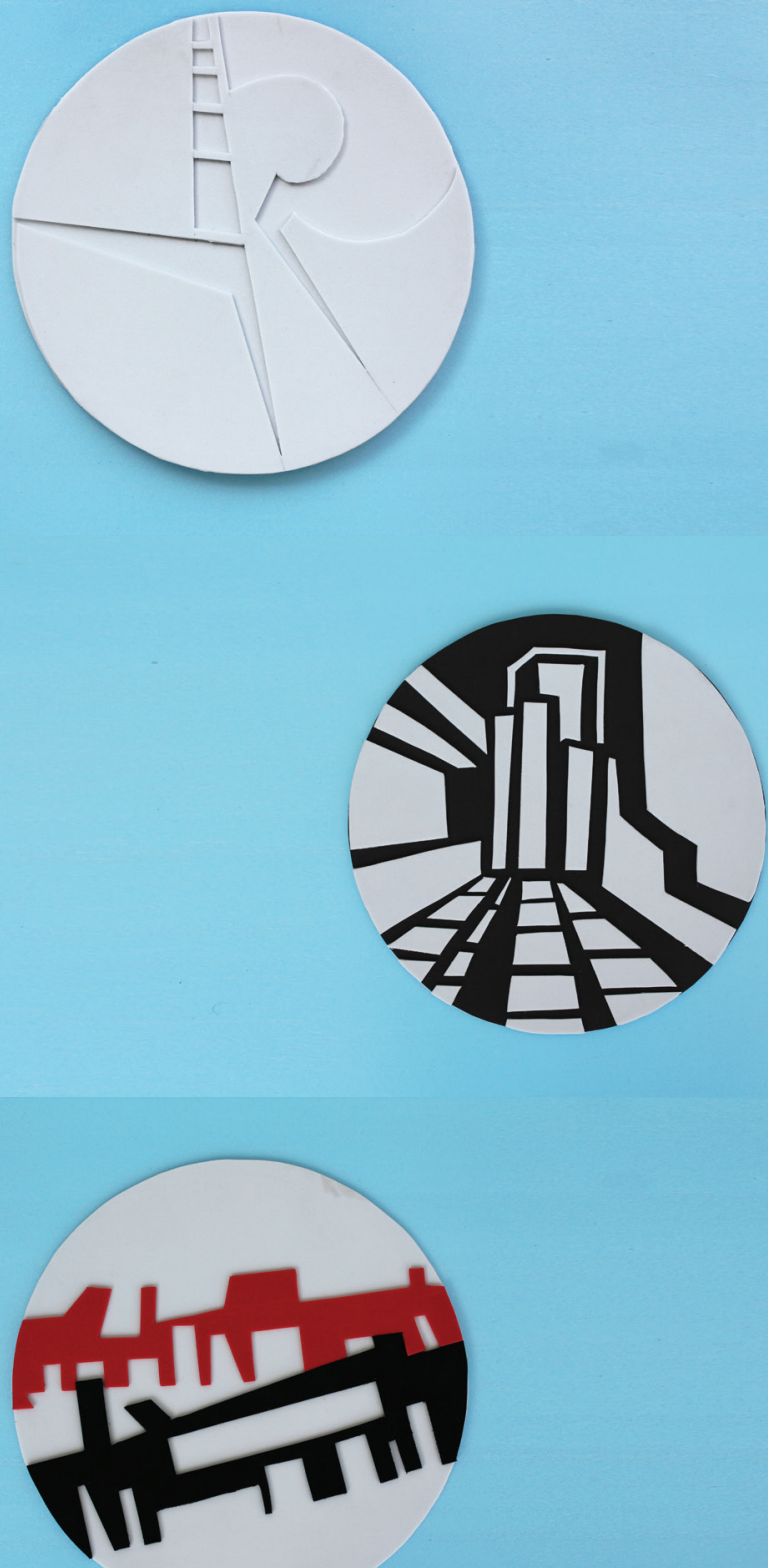


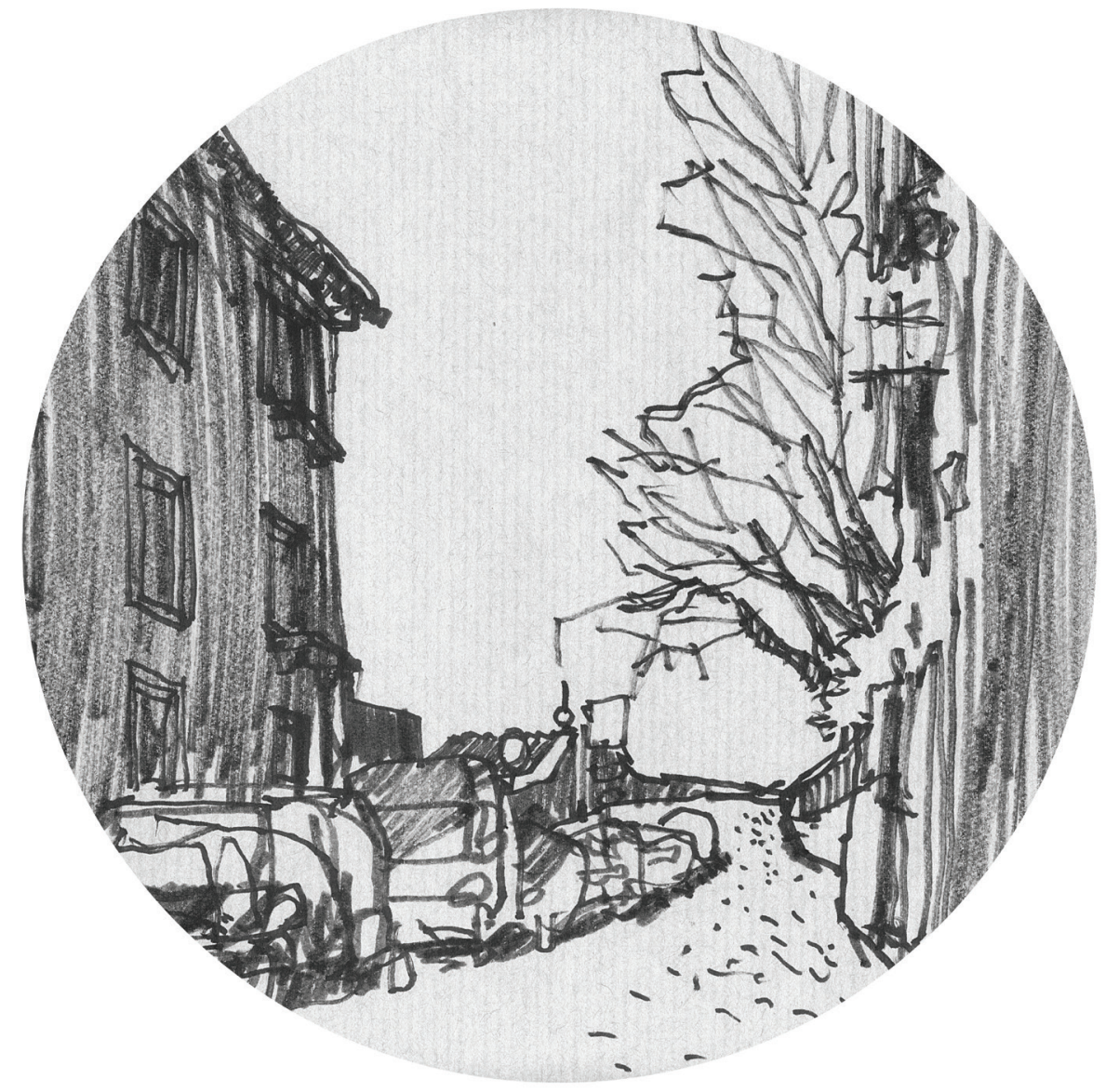


154

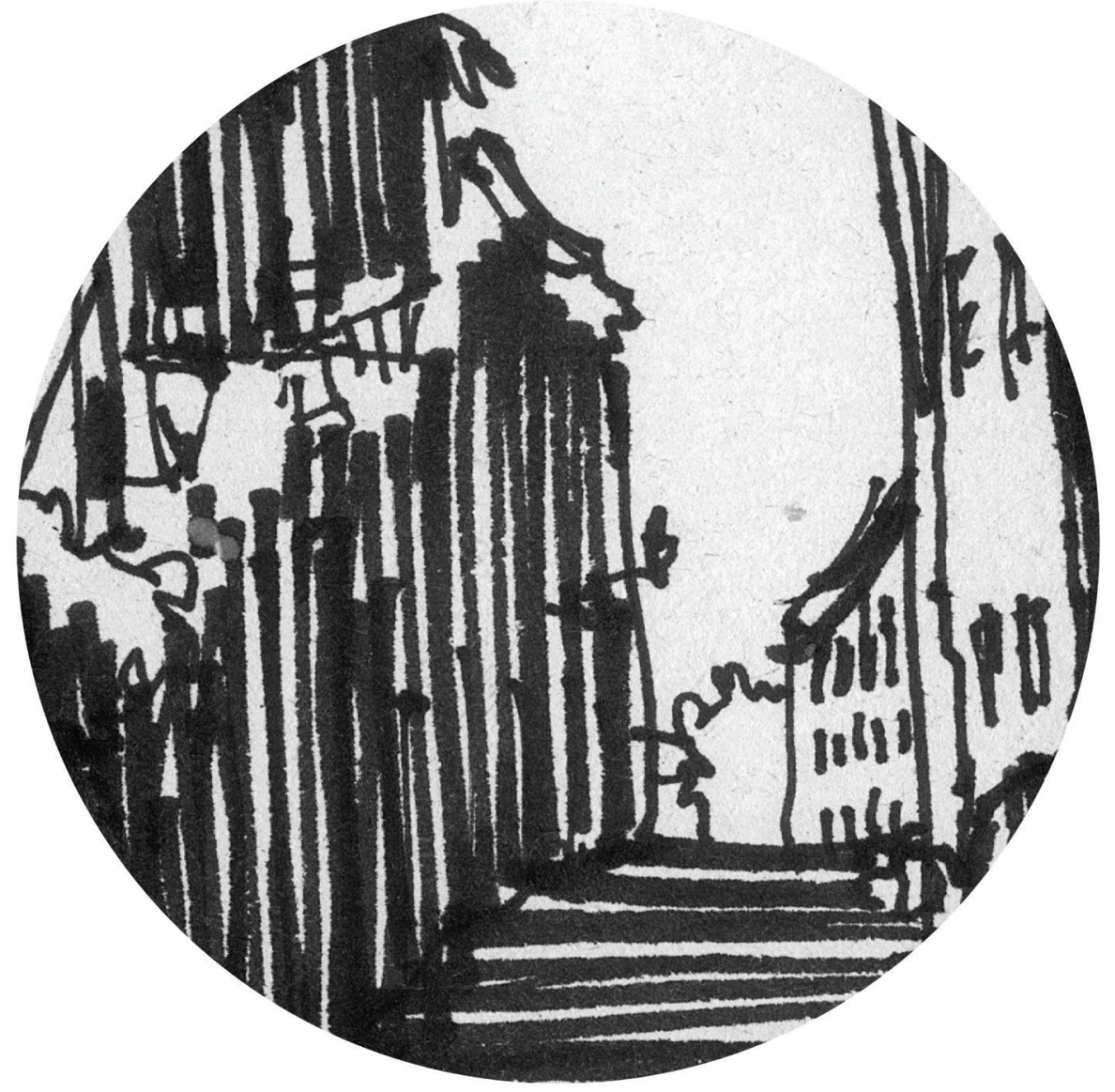




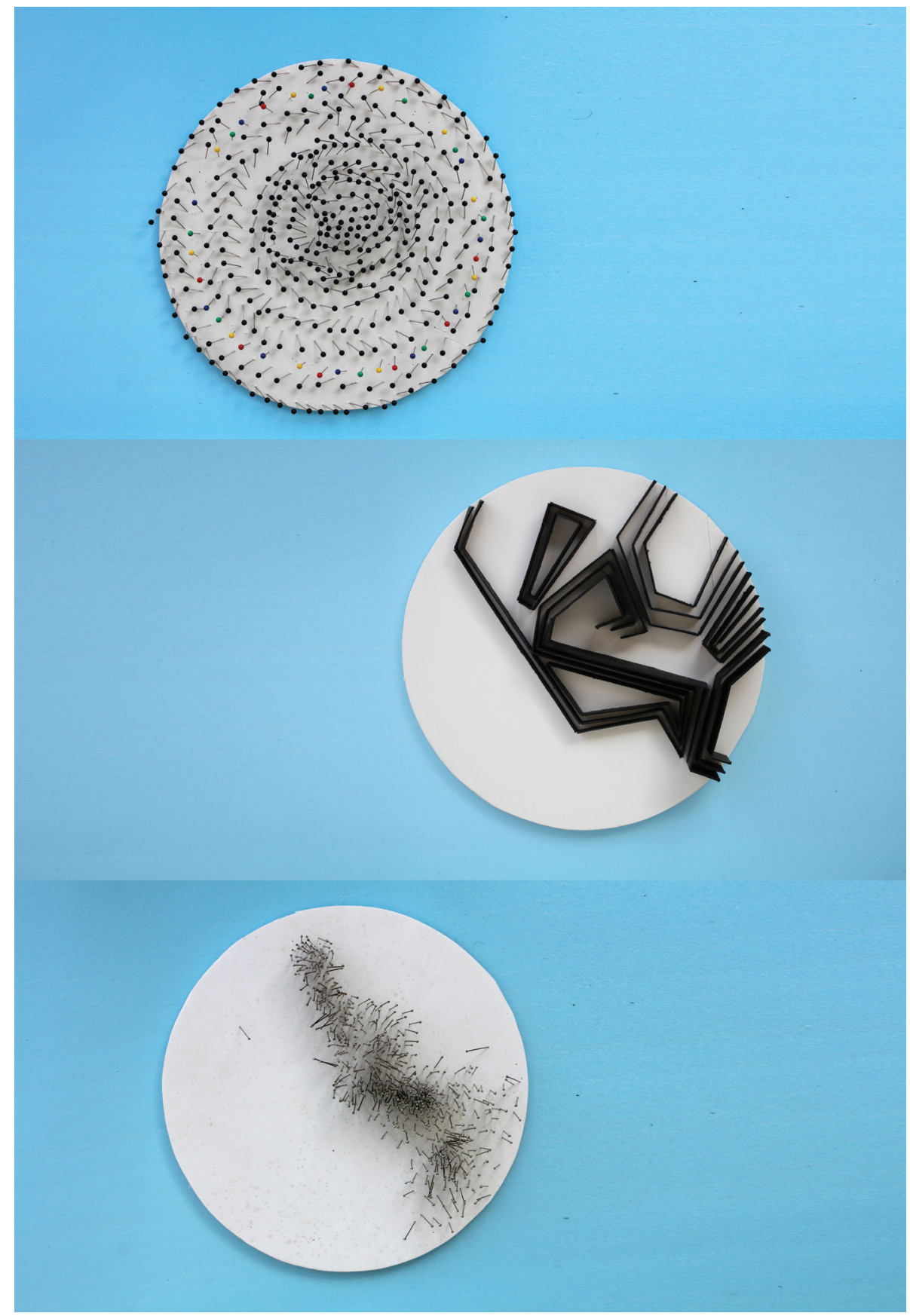



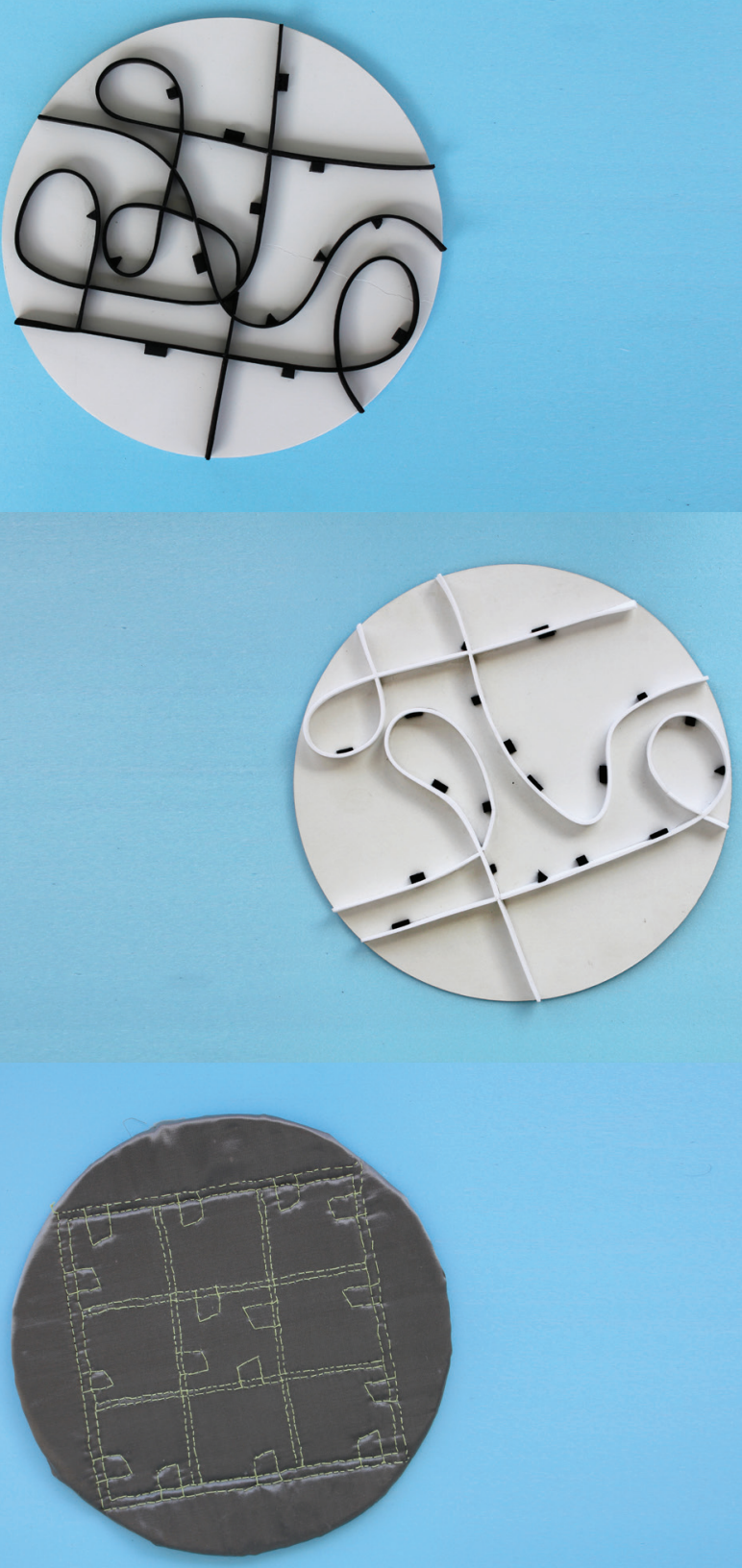


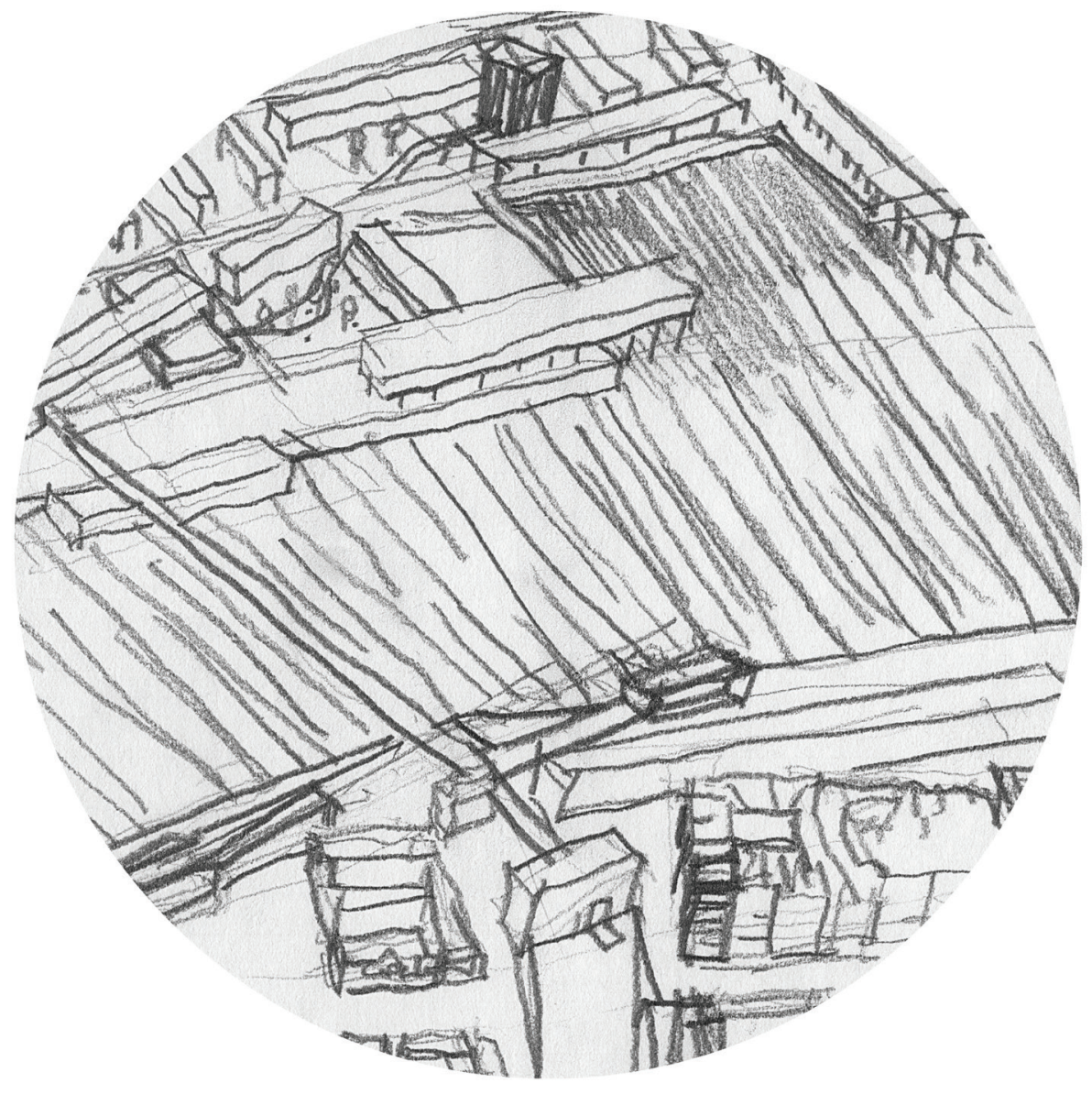




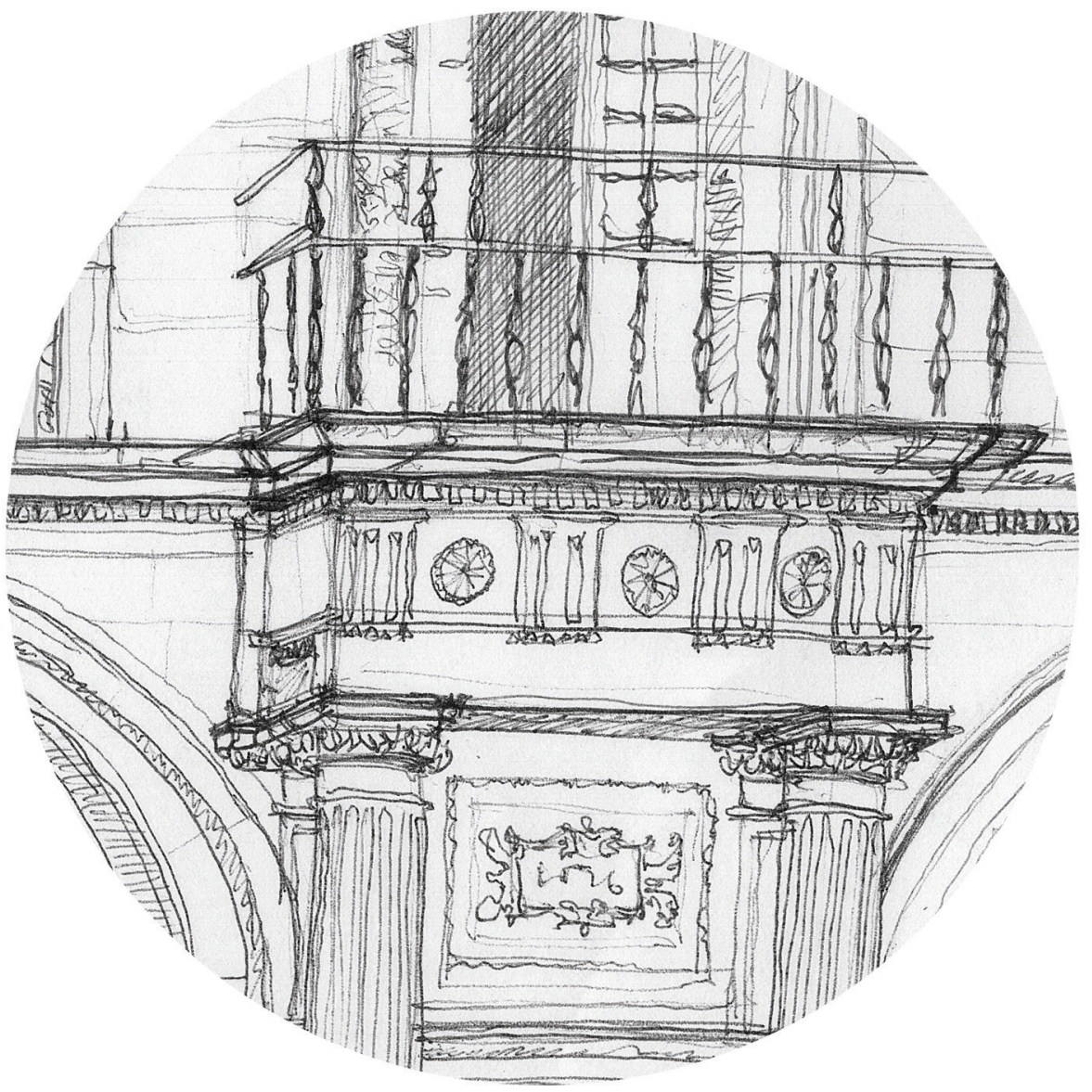




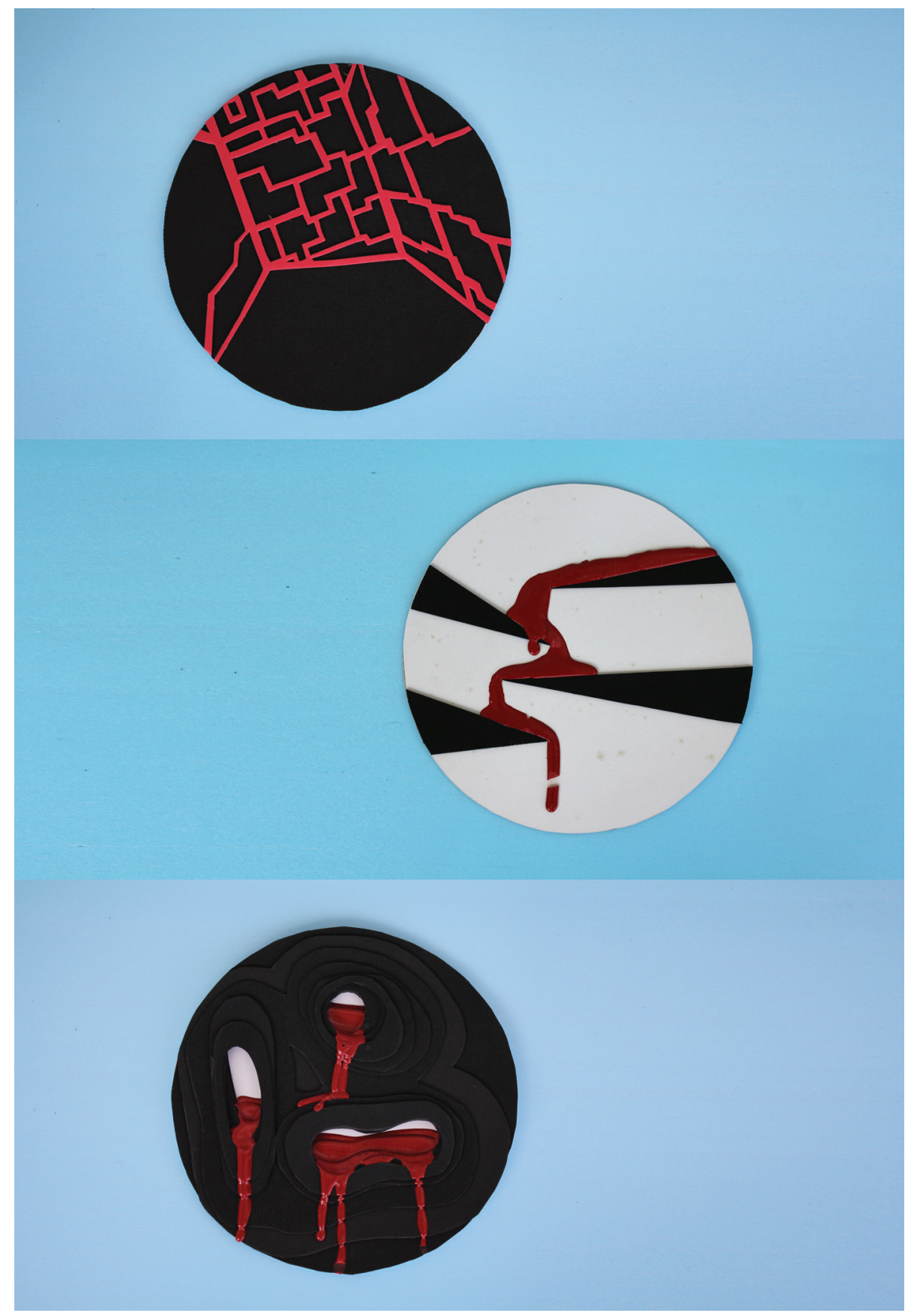



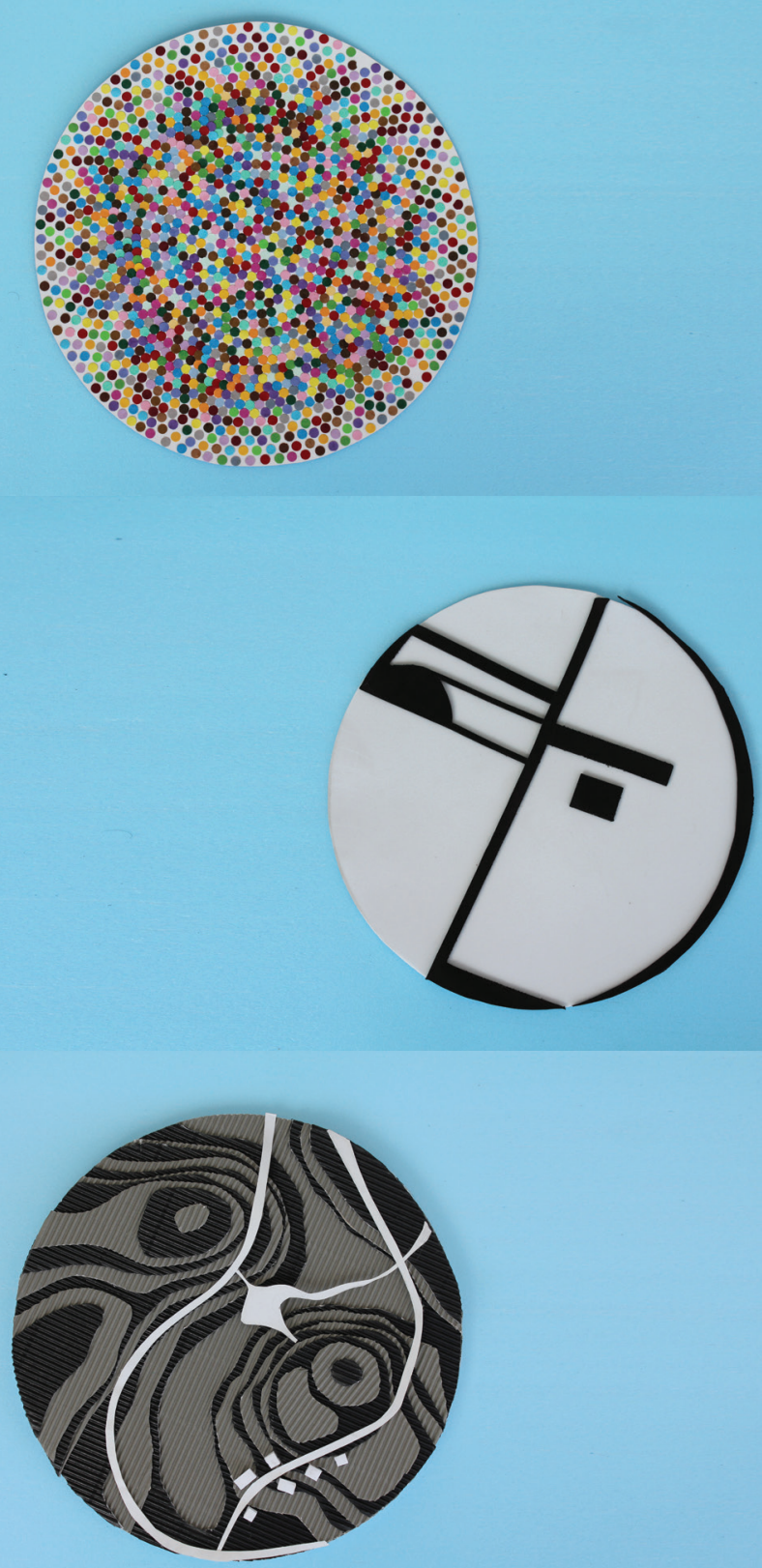

Maria Eduarda Duarte, Emmanuelle, Rui Figueredo 

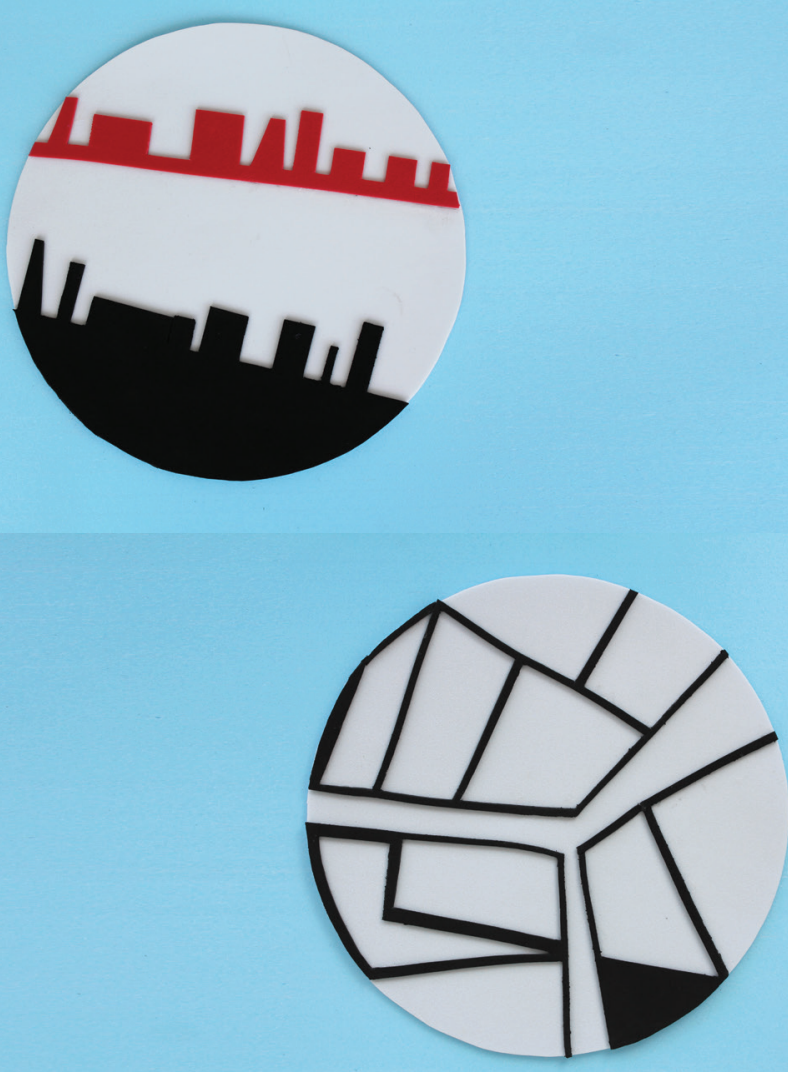

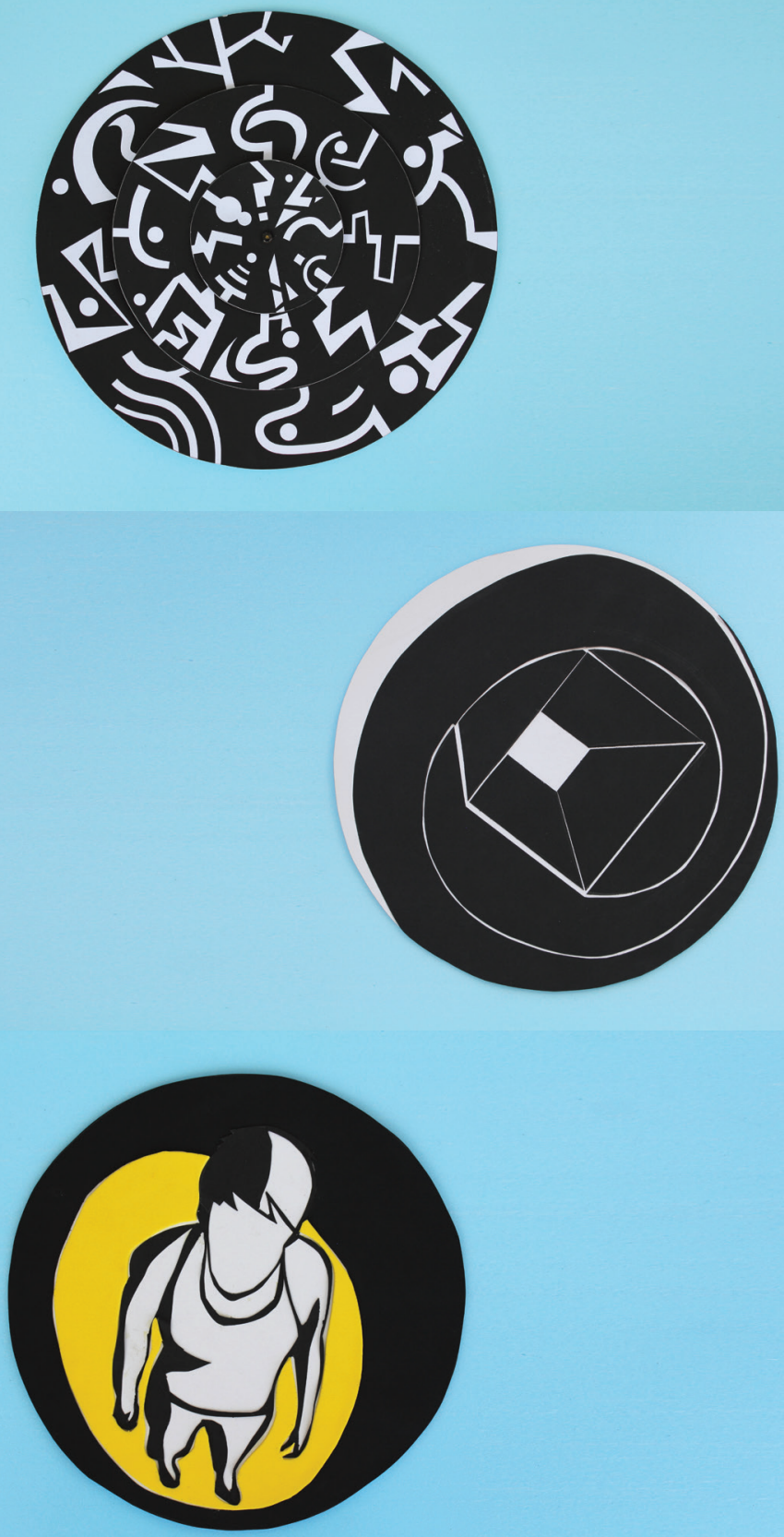


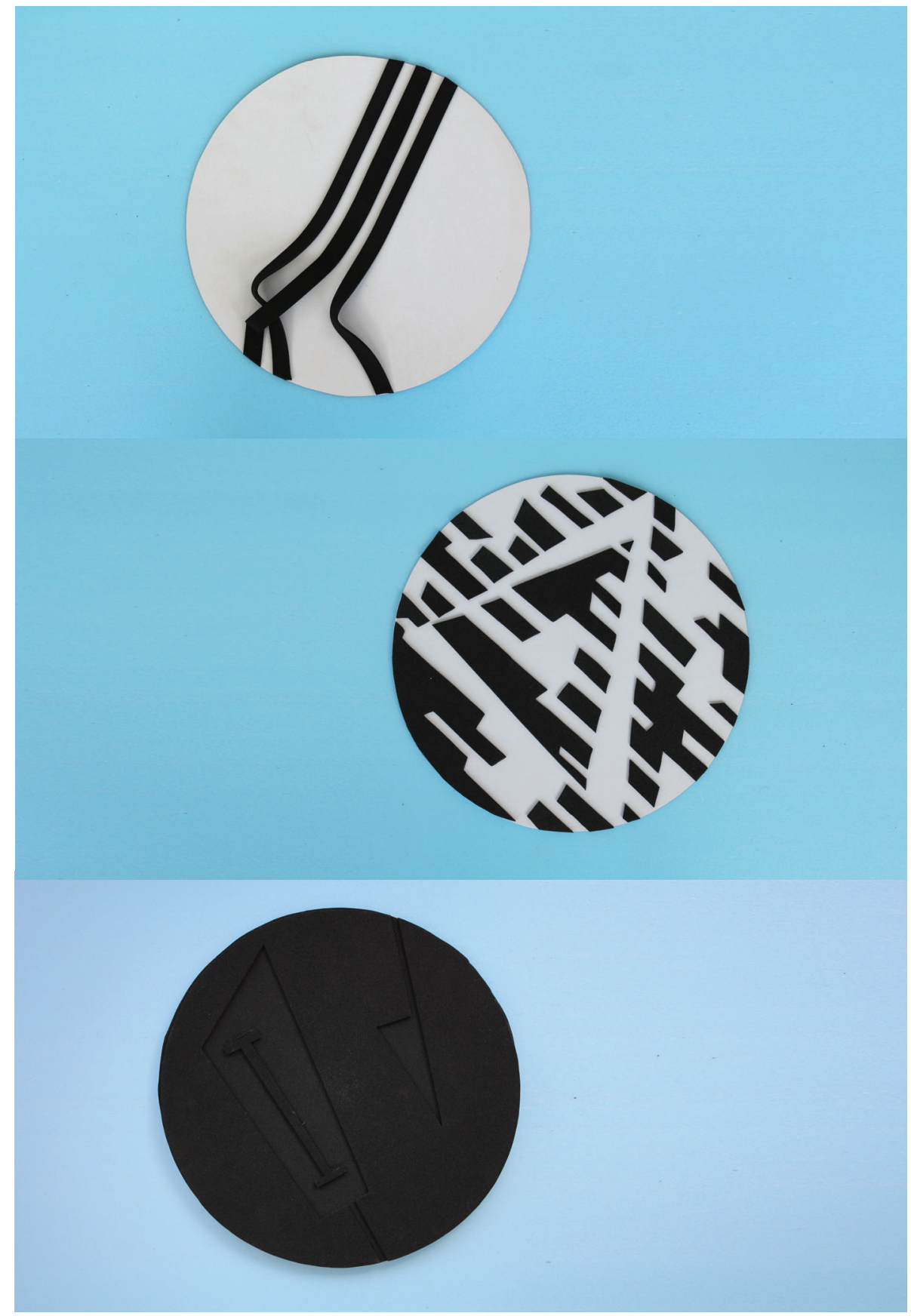



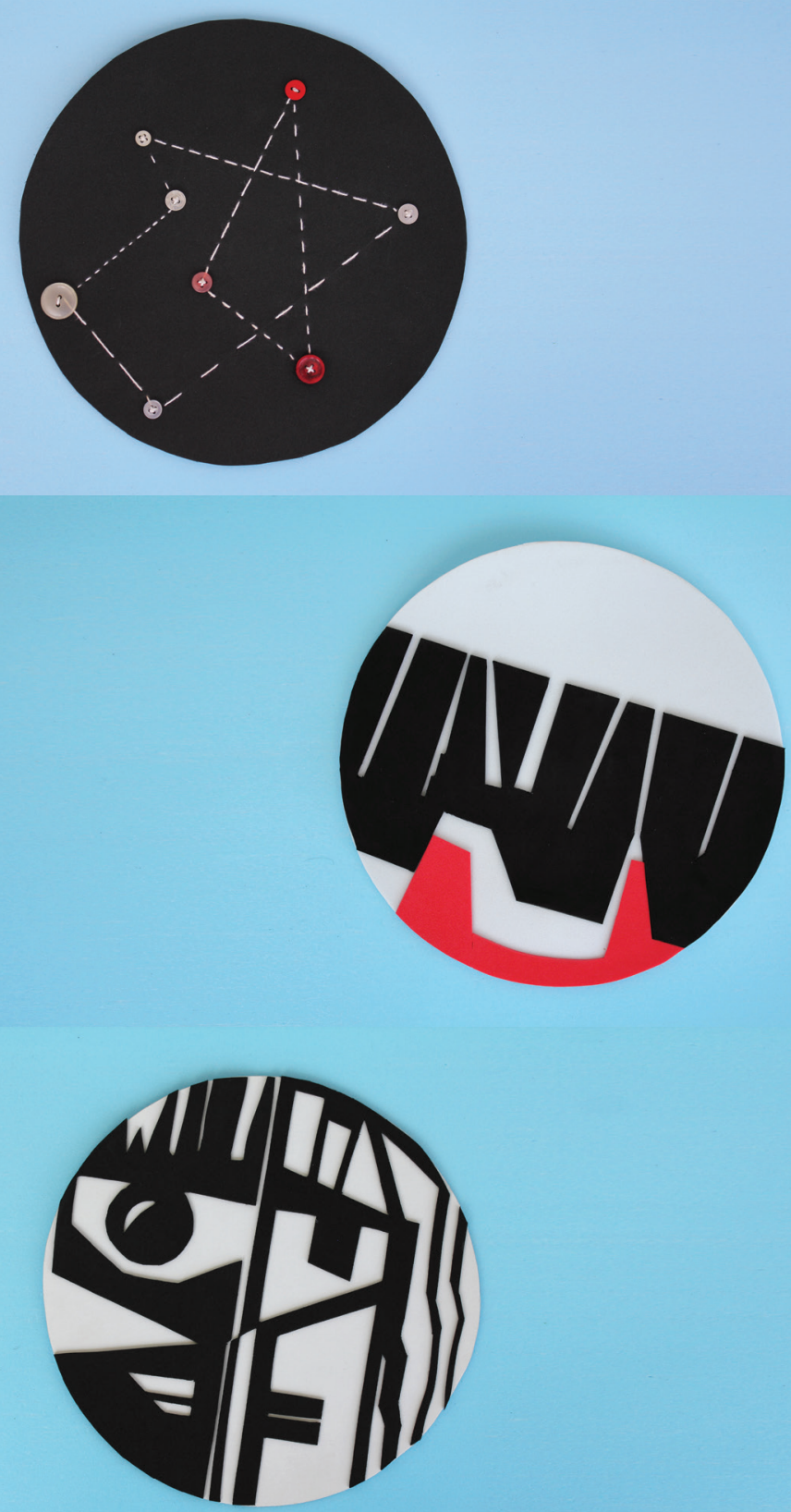


$$
\begin{aligned}
& 2 \\
& \mathbb{E} \\
& \mathbb{E}
\end{aligned}
$$


(Página deixada propositadamente em branco) 


\section{VELOCIDADE E MOVIMENTO}

A simultaneidade dos dois conceitos, velocidade e movimento, pode provocar a estranheza da presença de um território de redundâncias, mas, sobretudo, acaba por afirmar as diferenças e as especificidades de cada um. A velocidade quantifica-se, o movimento, não.

$\mathrm{Na}$ ambiguidade da relação entre velocidade e movimento, os alunos criaram objectos cujo desenho contrariava a natureza estática destas construçóes. Aqui a ideia de movimento/velocidade conduziria o desenho destas formas, dinâmica das formas não propriamente qualidade dos objectos que se movem.

A dimensão arquitectónica destes objectos conferia-lhes a possibilidade de poderem ser maquetes, aproximando-os da ideia de projecto.

Evocada assim a arquitectura, a ideia de movimento ganhava uma expressão particular, fazendo mover o que tomaríamos como estático, ou acentuando poeticamente a dimensão dinâmica da arquitectura. 
(Página deixada propositadamente em branco) 


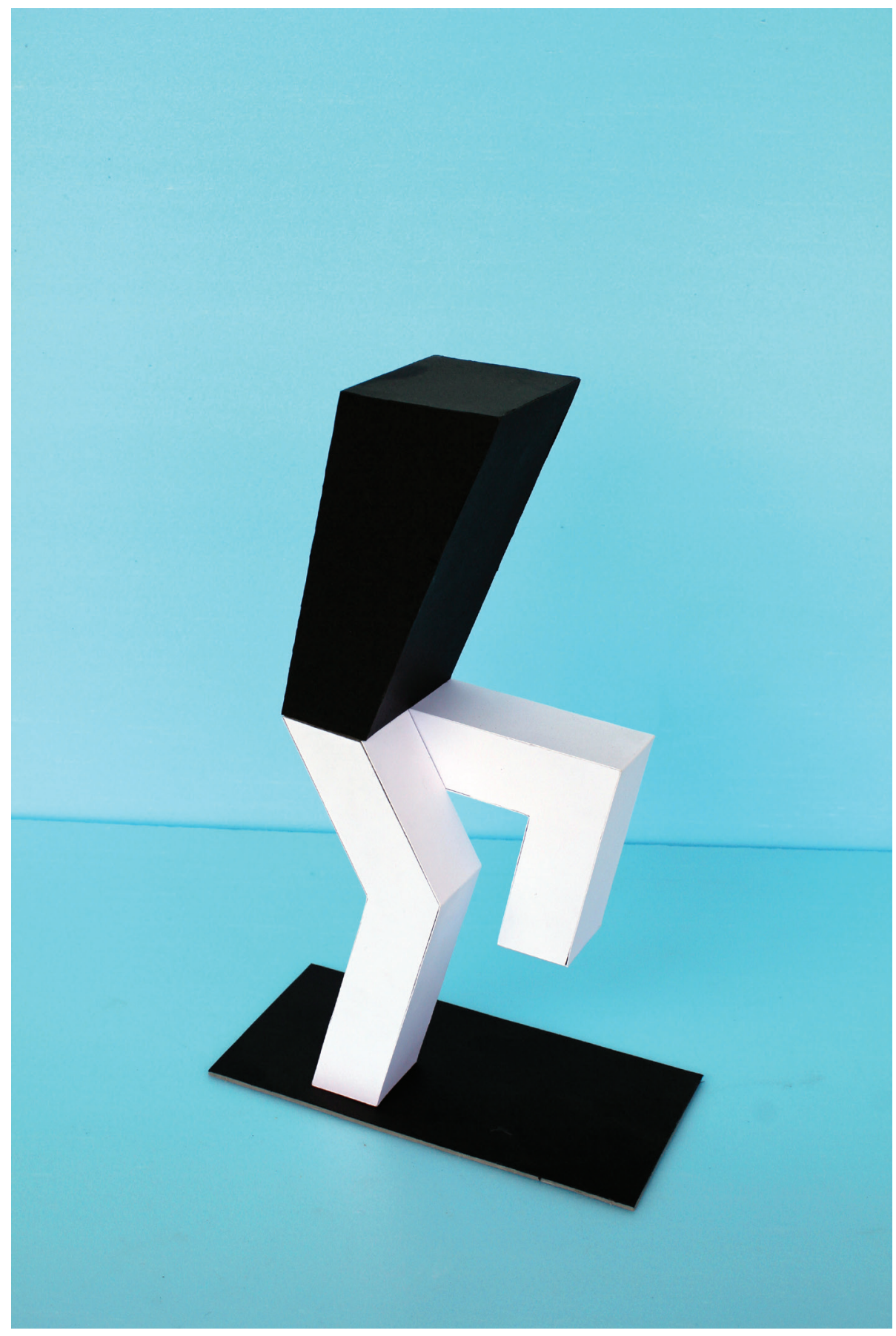




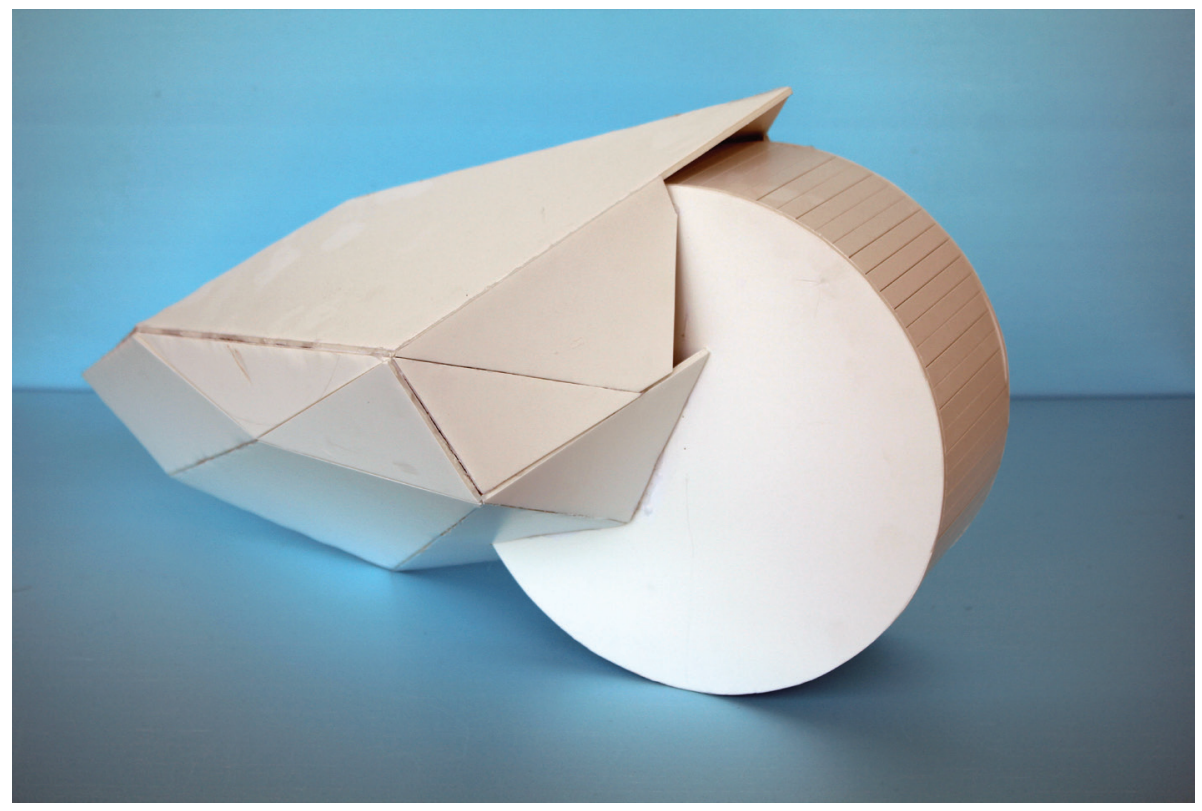

Tiago Martins 


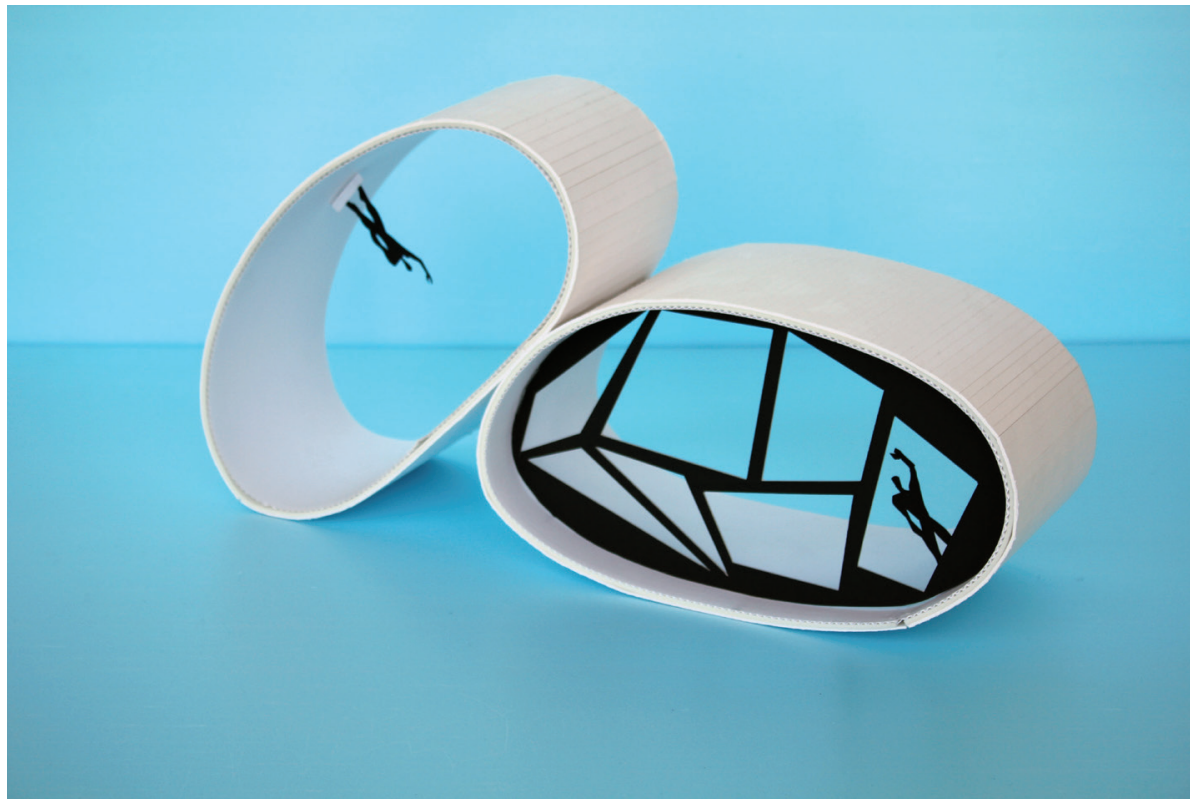




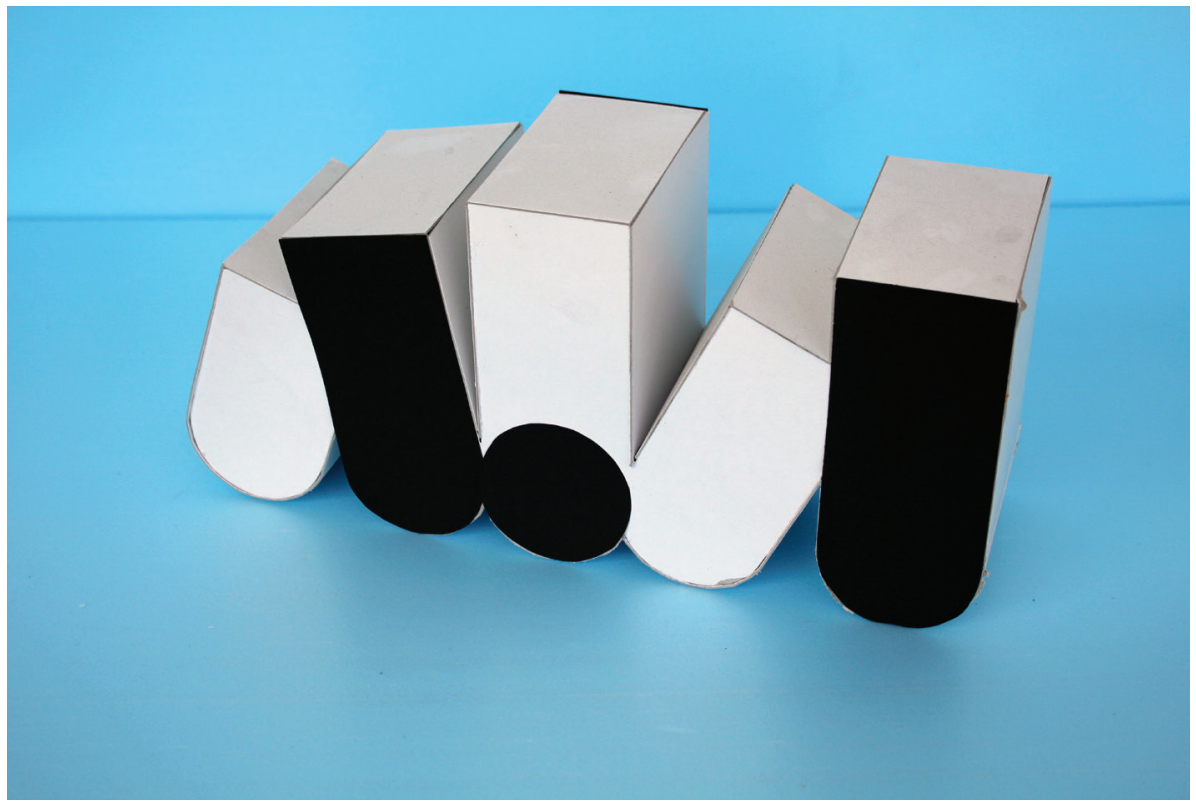

Vânia Simões 


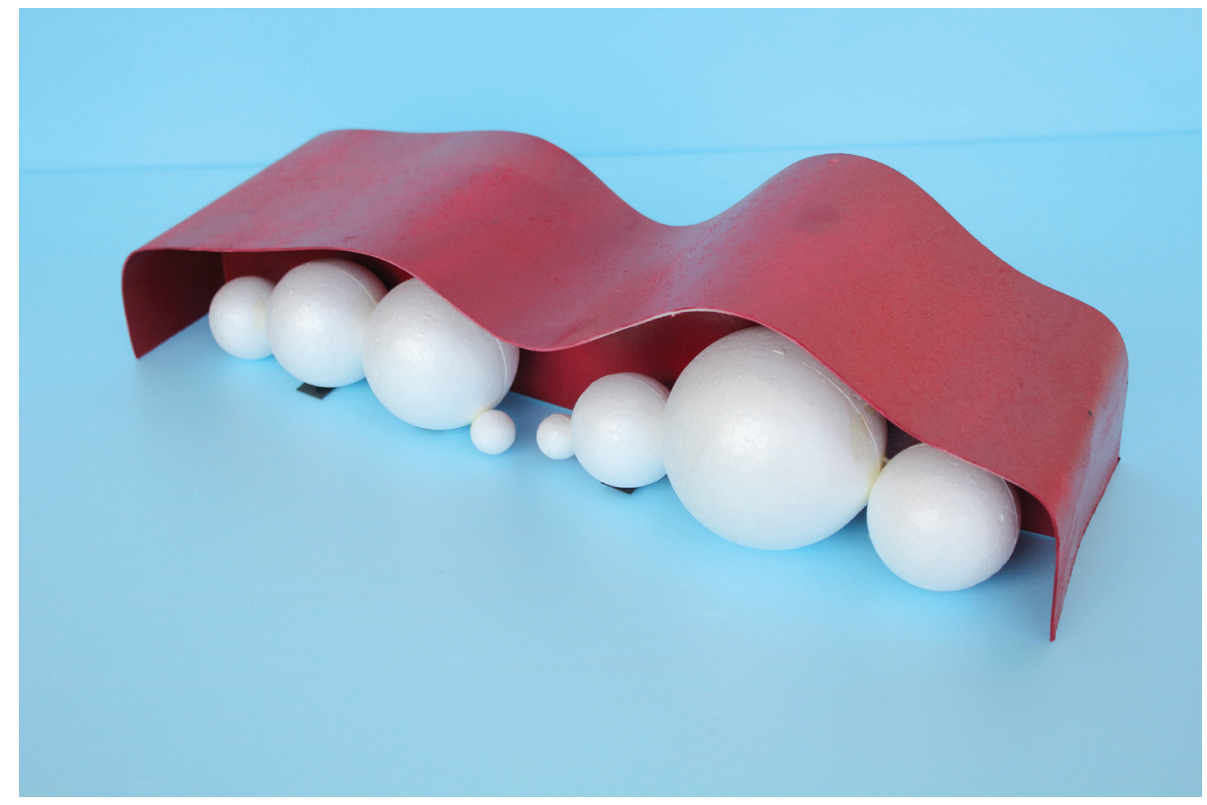



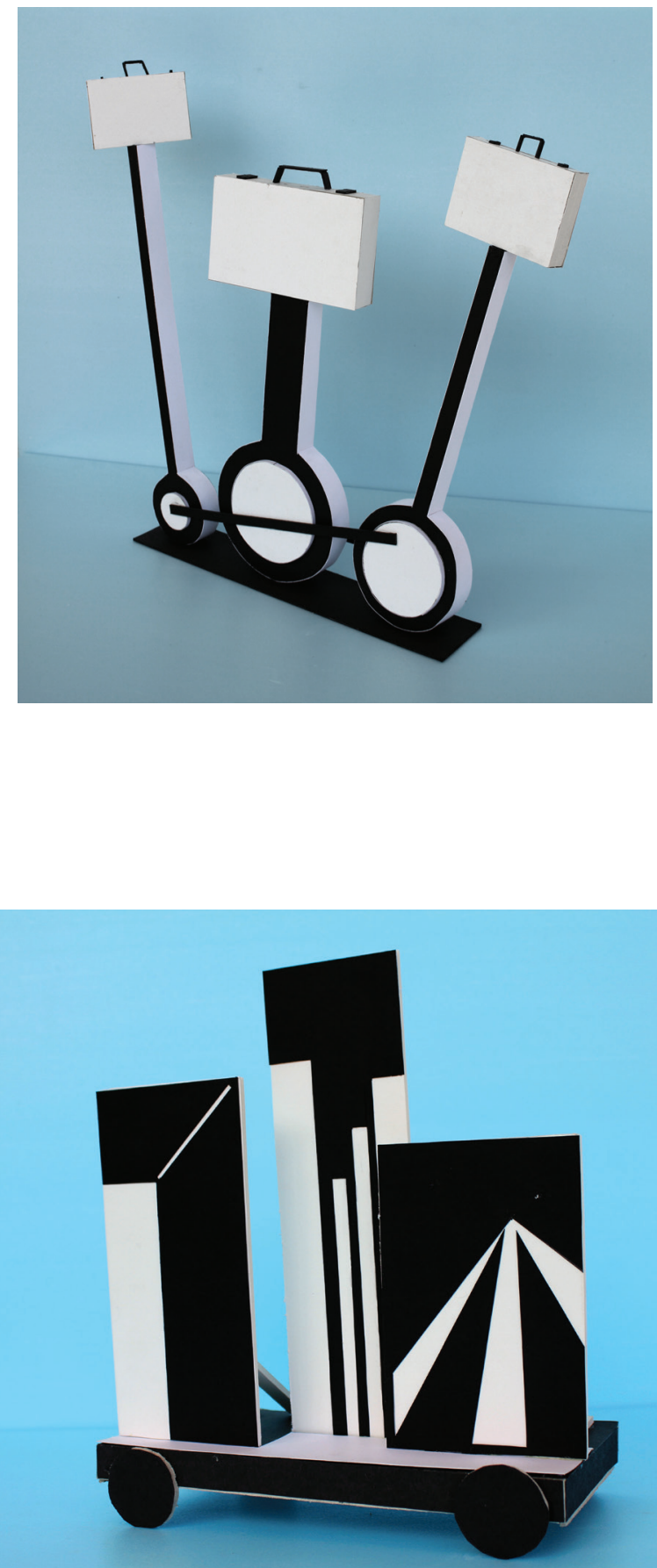

Rosa Bandeirinha, Ana Filomena Carvalho 


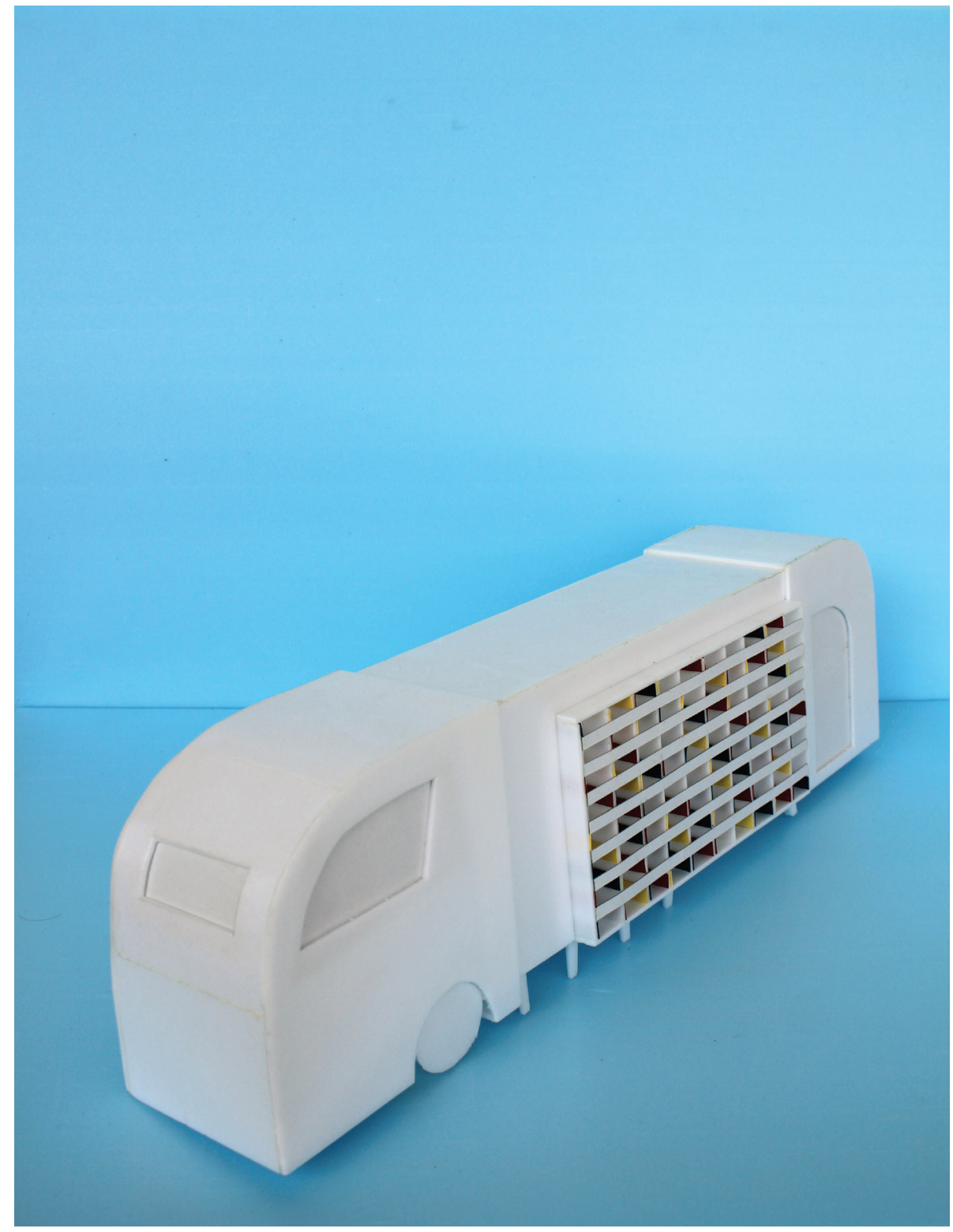



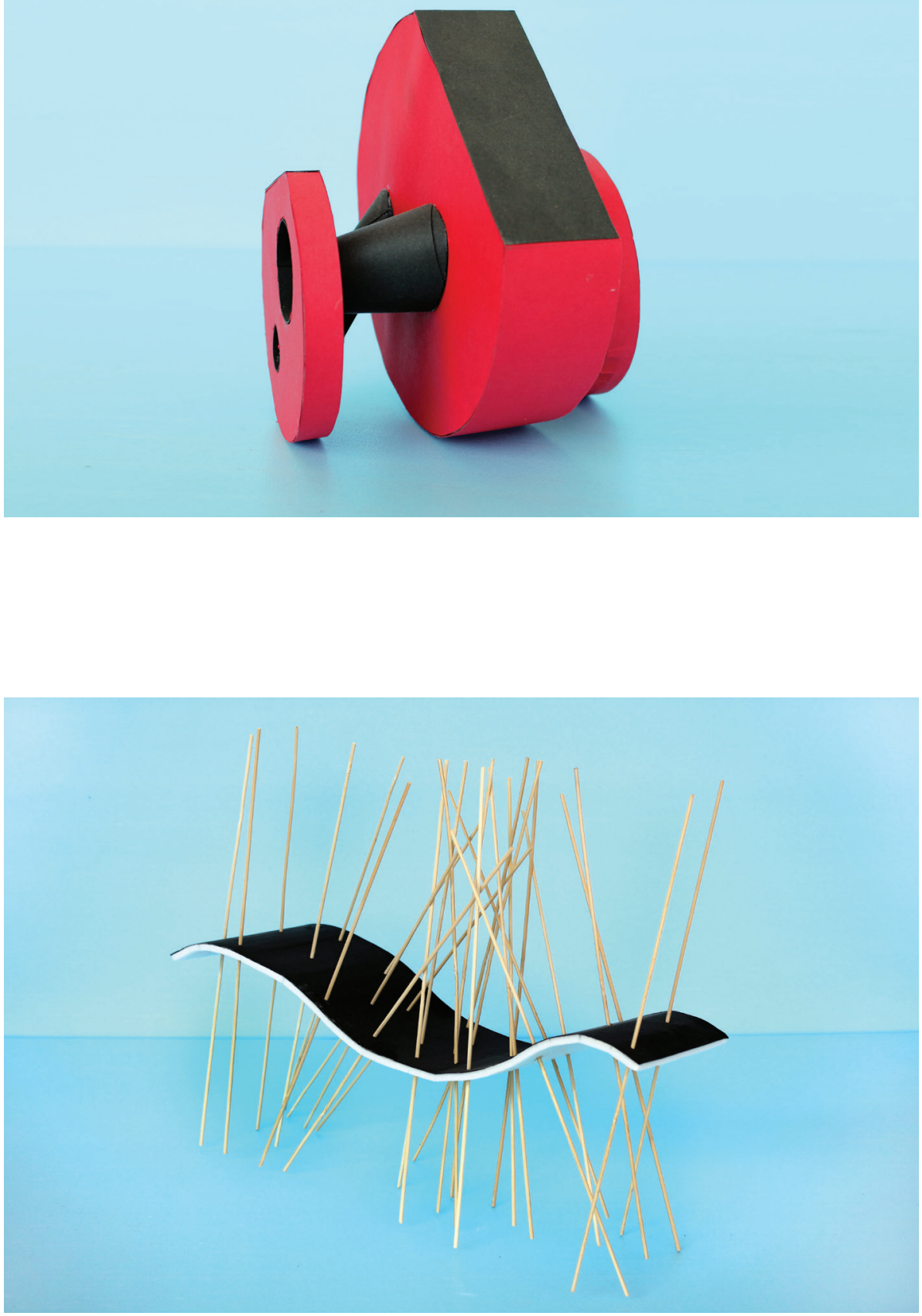

Paula Maria Monteiro 

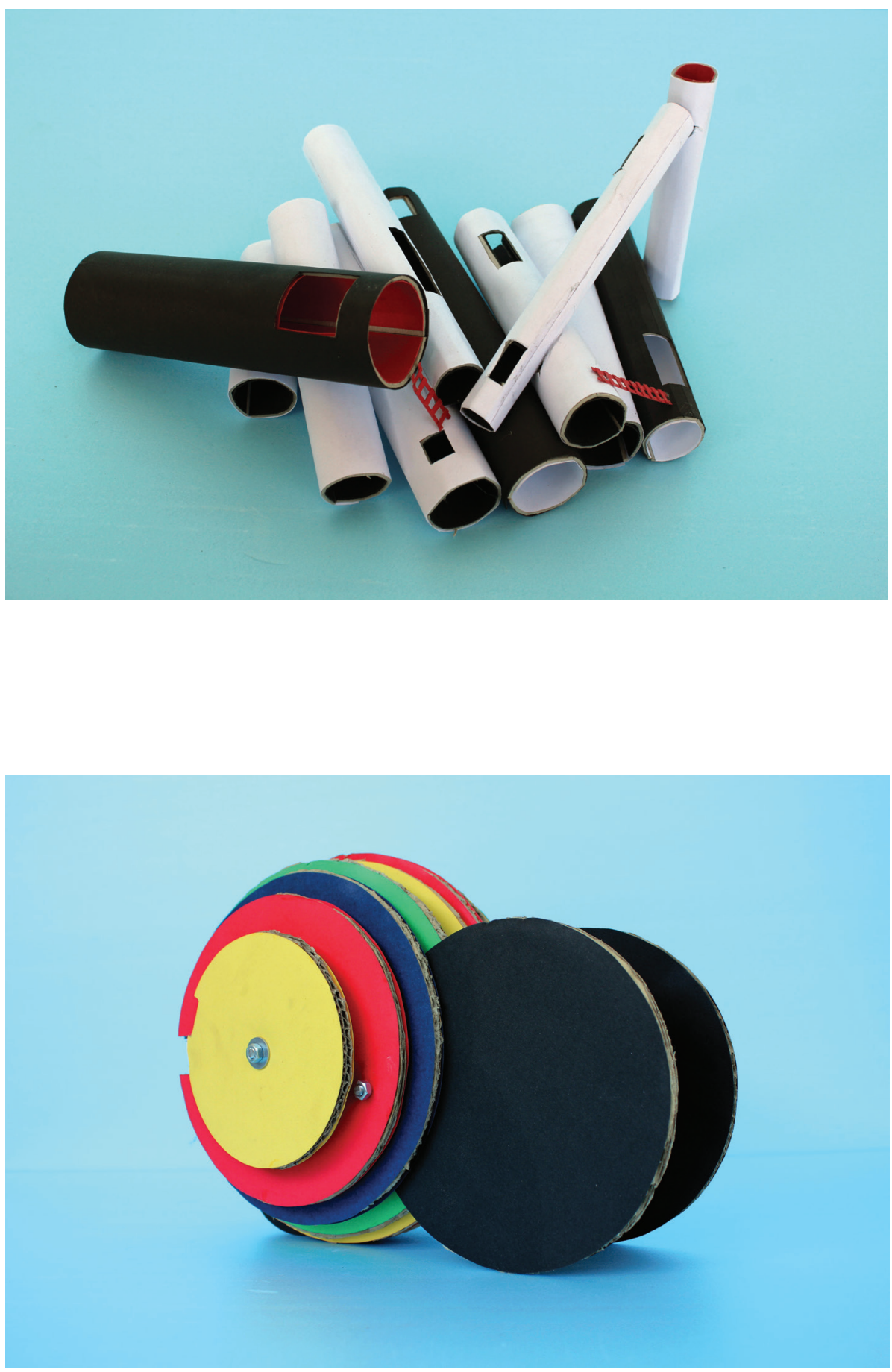

Diana Patrão, Diana Ferreira 

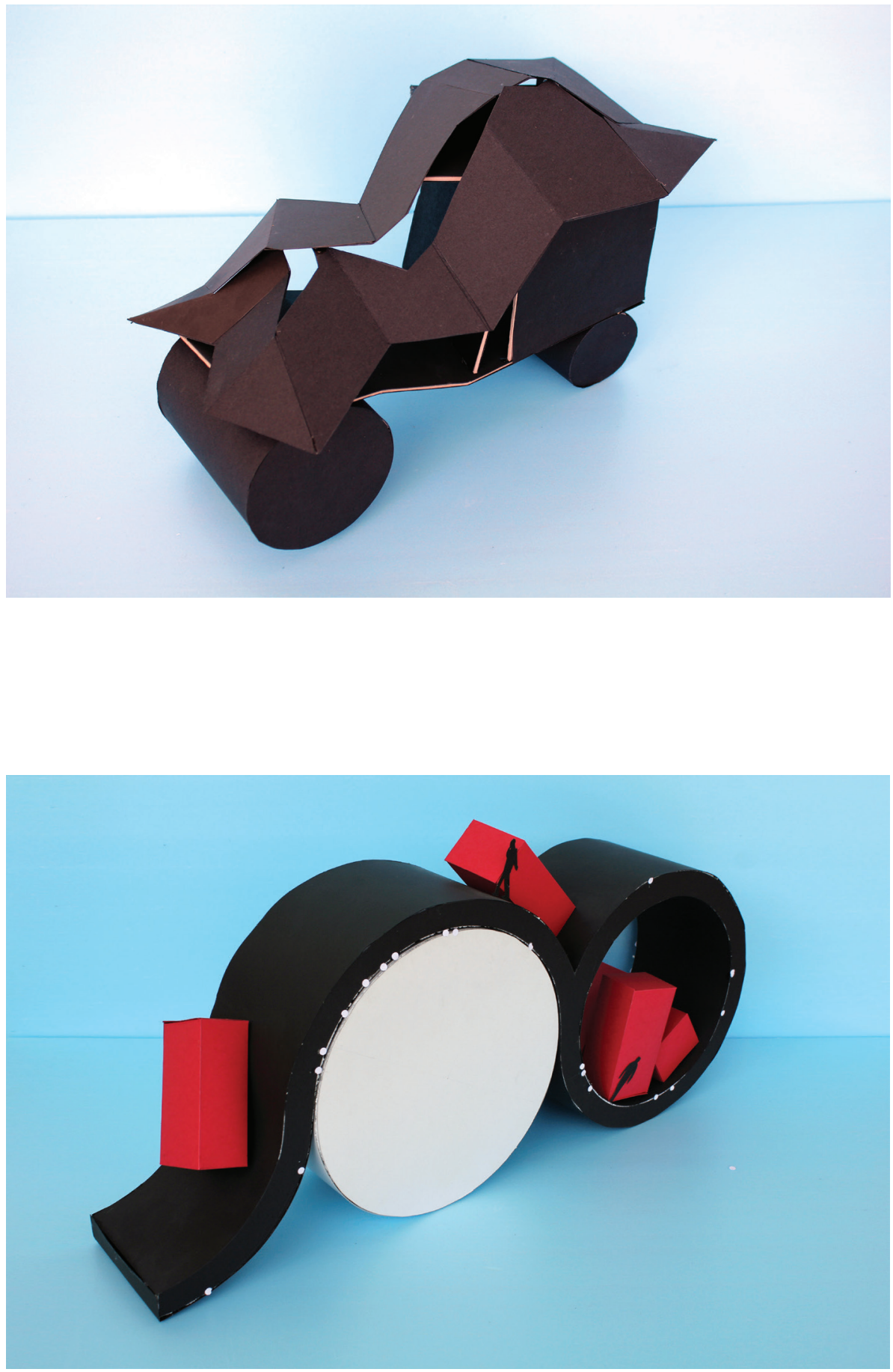

Luís Alves 

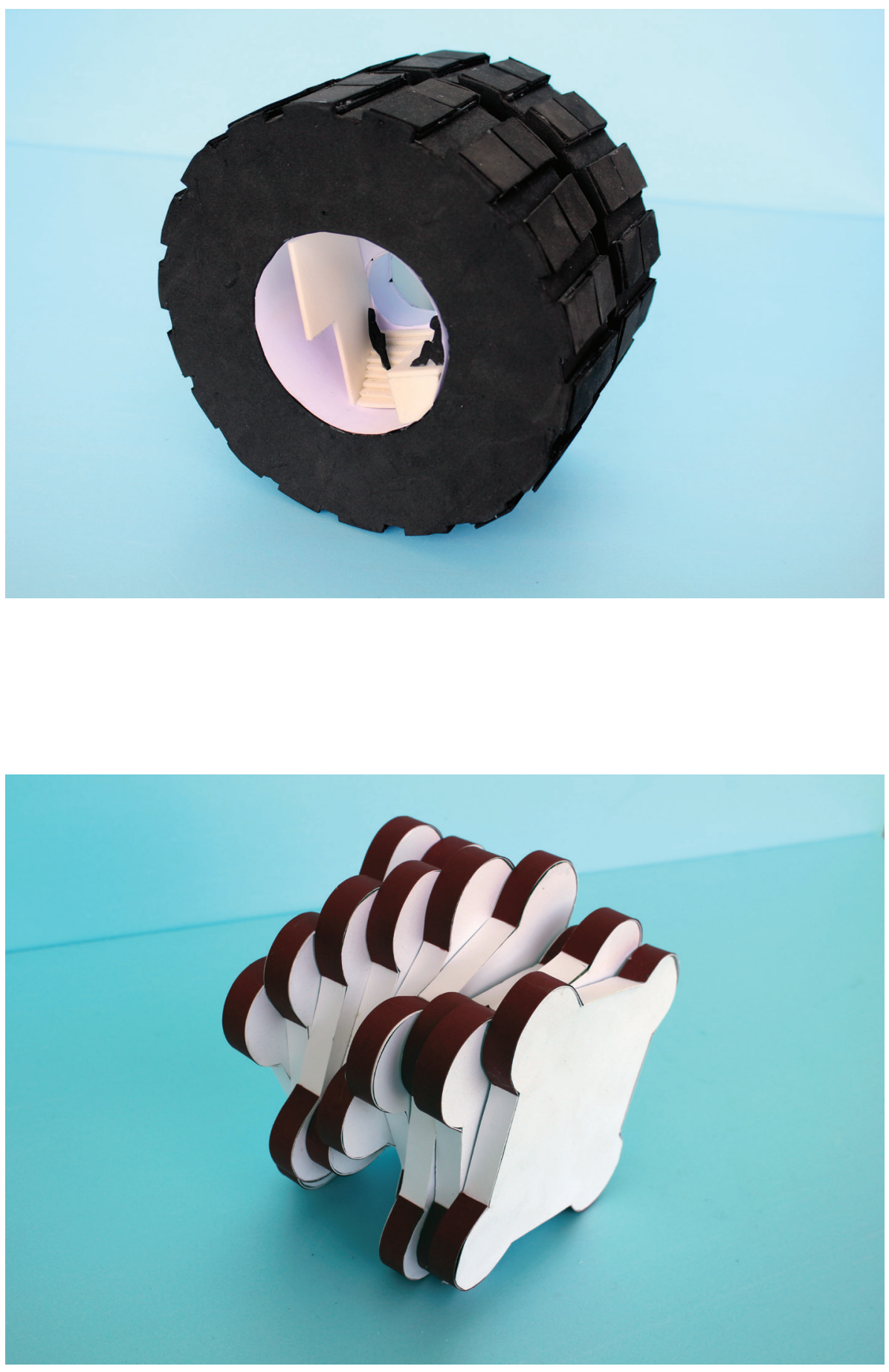

Mabely Moreira, Joana Melo 


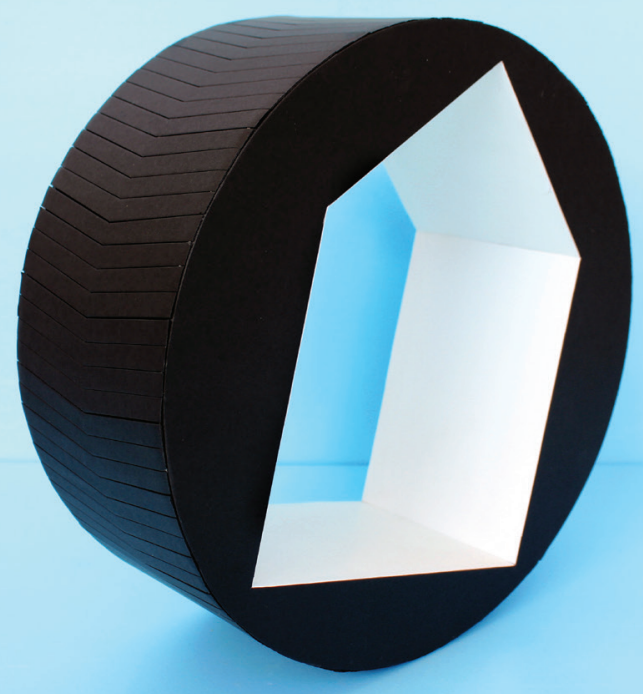

Francisco Mendes 


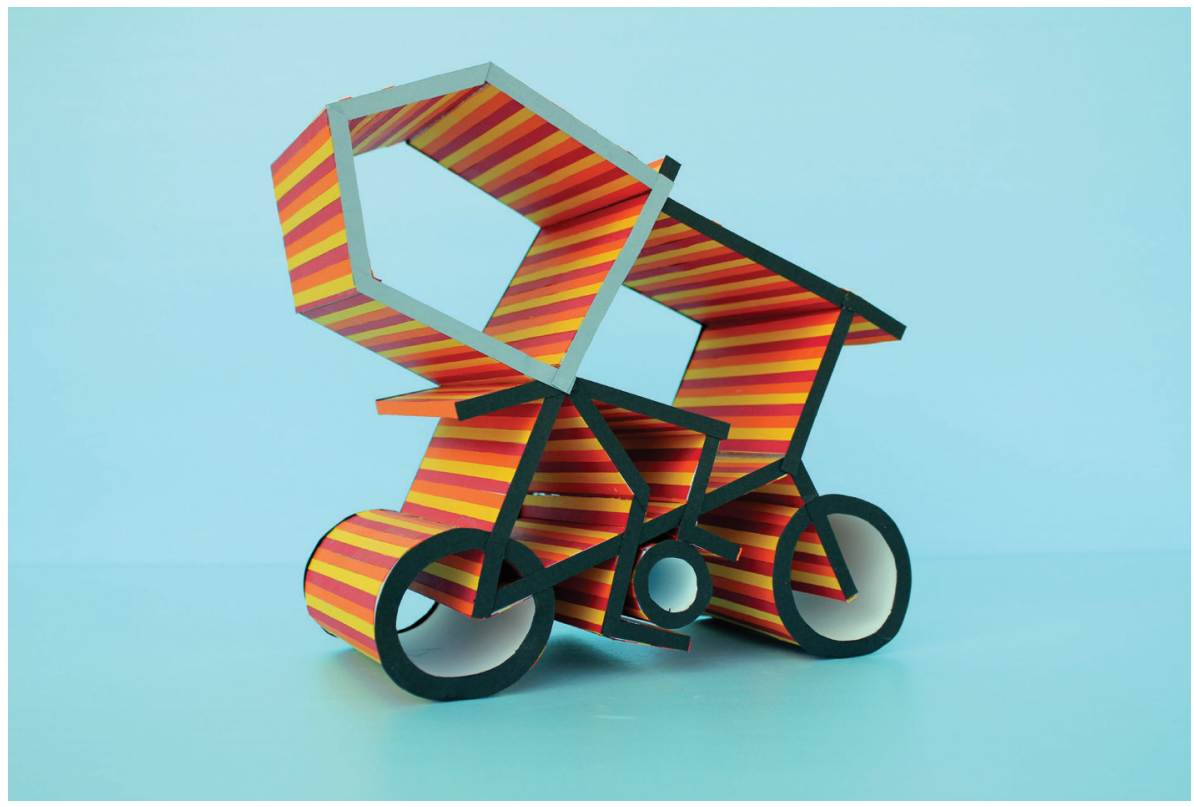


(Página deixada propositadamente em branco) 
Nos trabalhos que integraram a exposição Versailles, o desenho é evocado enquanto processo transformador. E, no contexto de um curso de arquitetura, aqui optámos por serem as paredes das próprias salas de exposiçóes o objeto da transformação.

As formas criadas não se sobrepuseram meramente às paredes como o fariam os quadros de uma exposição. Foram desenhadas como elementos que se salientam das paredes agarrados à sua estrutura formal à semelhança do ornamento em arquitetura. Aqui, a citaçáo do ornamento, evidencia a sua capacidade de desmaterializar o objeto arquitetónico. Talvez seja esta capacidade do ornamento de transformar a realidade física de um espaço, de estar num espaço e evocar outros que o torna frequentemente táo popular (a sedução da imaginação?).

Mas o principal desafio desta exposição está em diluir a distância entre o ornamento e projeto arquitetónico, onde a ambiguidade das escalas e a fusão entre a bidimensionalidade e as volumetrias contribuem para sublinhar as essencialidades formais.

As salas desta exposição, mais do que arquitetura, sendo reflexão sobre arquitetura tornada imagem, manifestam-se enquanto espaços cénicos que, mais do que para olhar são para se estar. A escolha da palavra Versailles como título desta sublinha a dimensão performática desta sala assim transformada, na provocação do anacronismo, ou, melhor, na sugestâo de que em arte nada é anacrónico, porque, em arte, tudo é contemporâneo.

António Olaio

(Participaram nestes trabalhos todos os alunos da disciplina de Desenho II do ano lectivo 2007/2008) 
(Página deixada propositadamente em branco) 


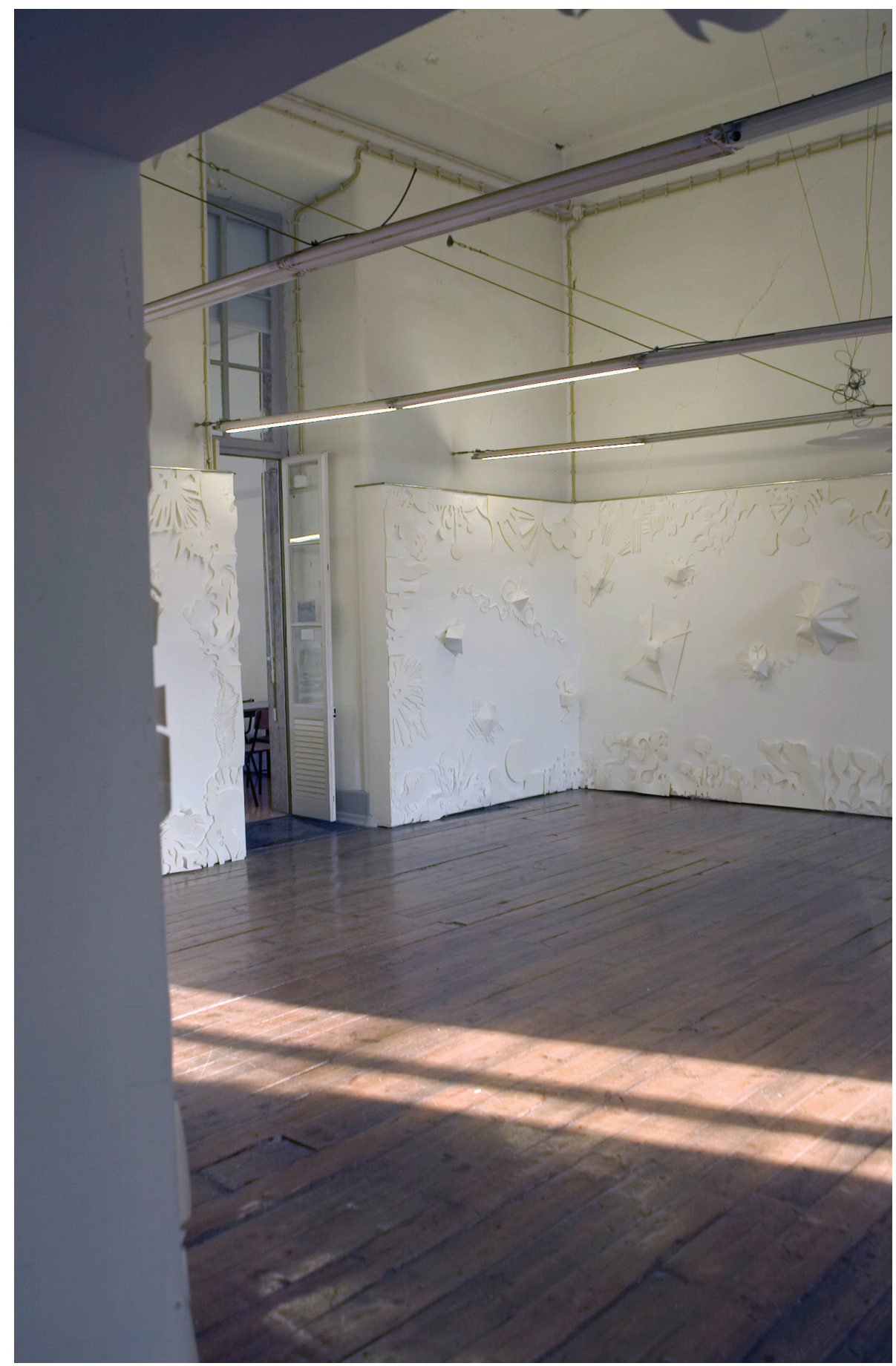

185 


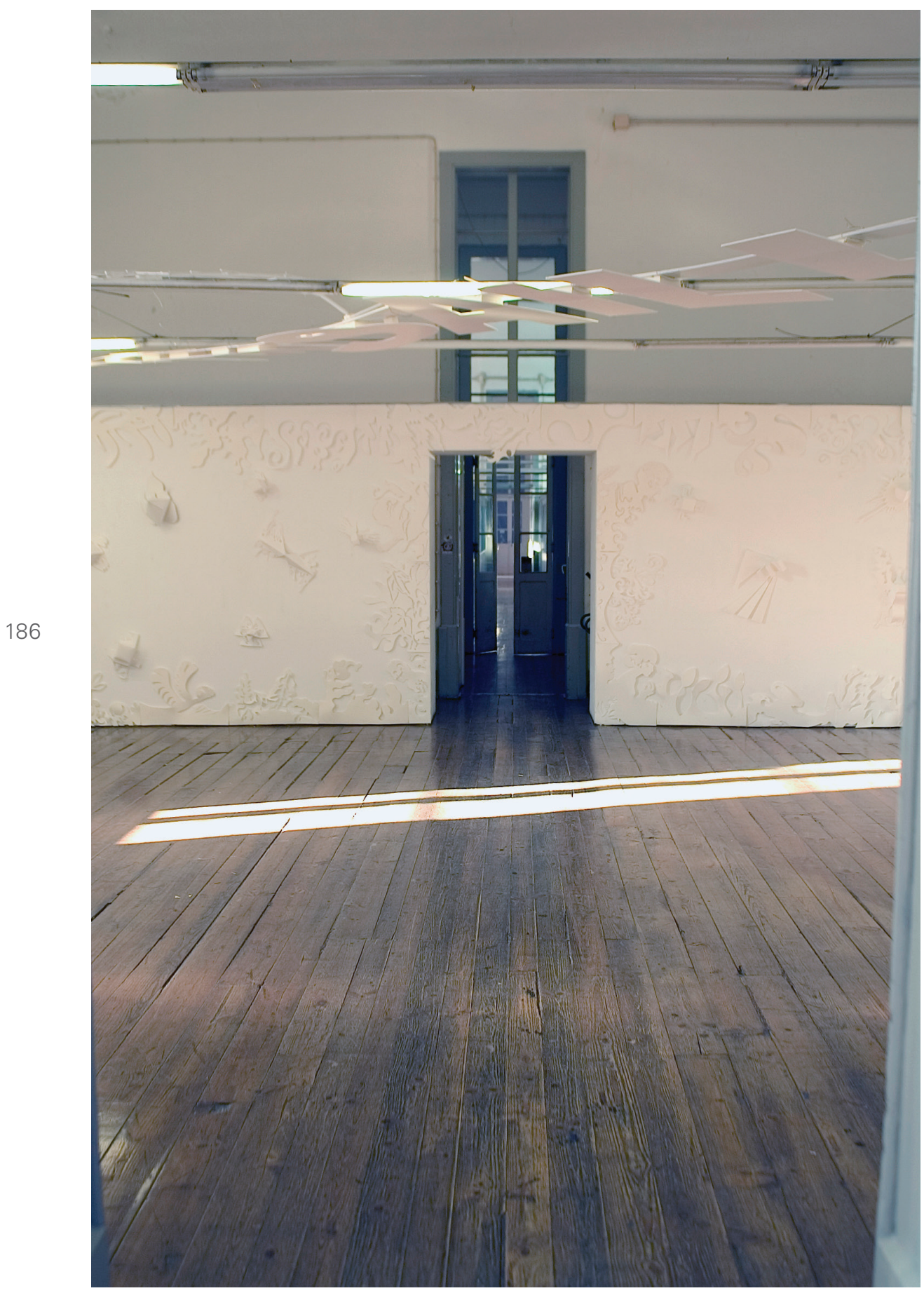




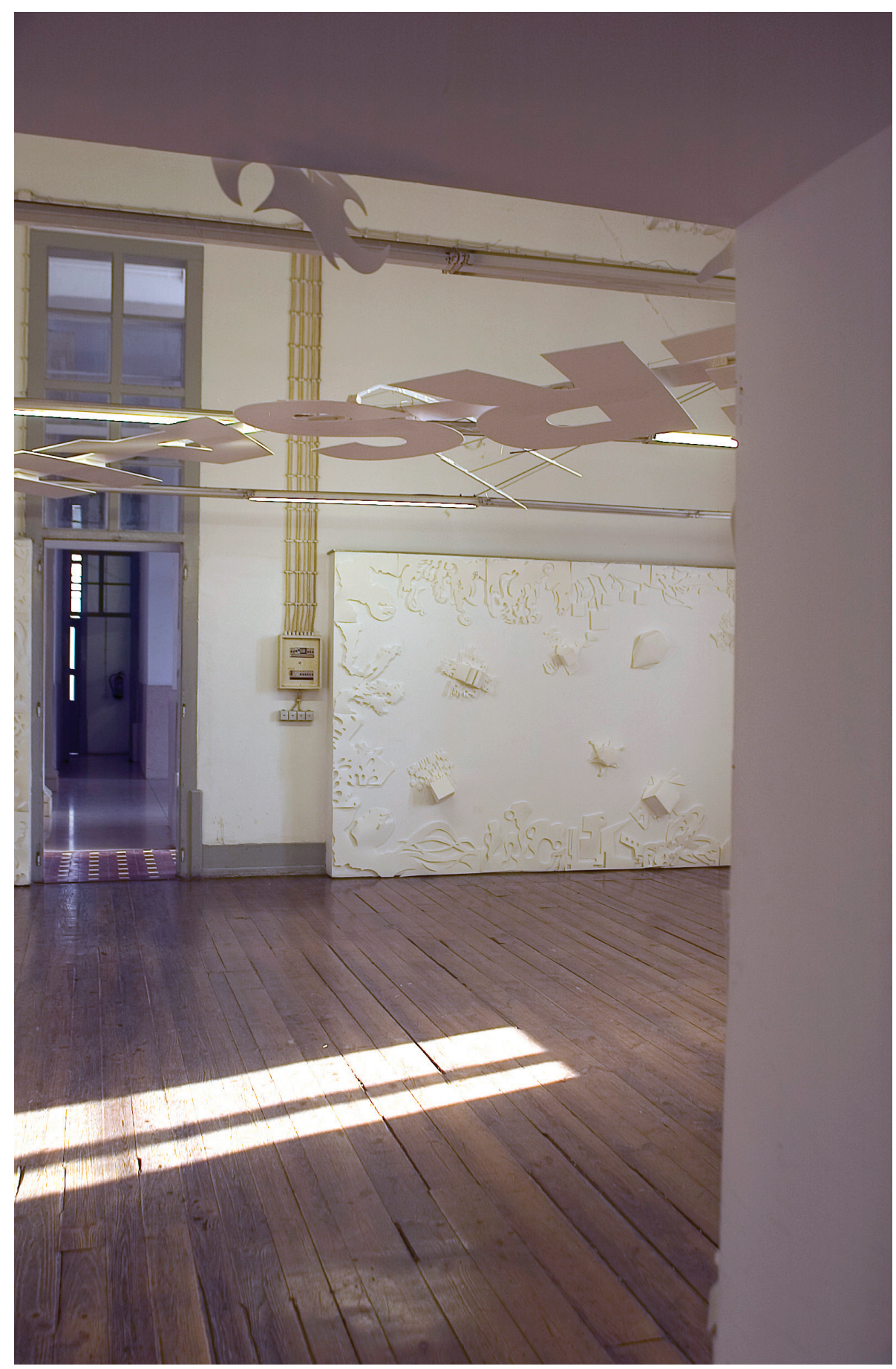




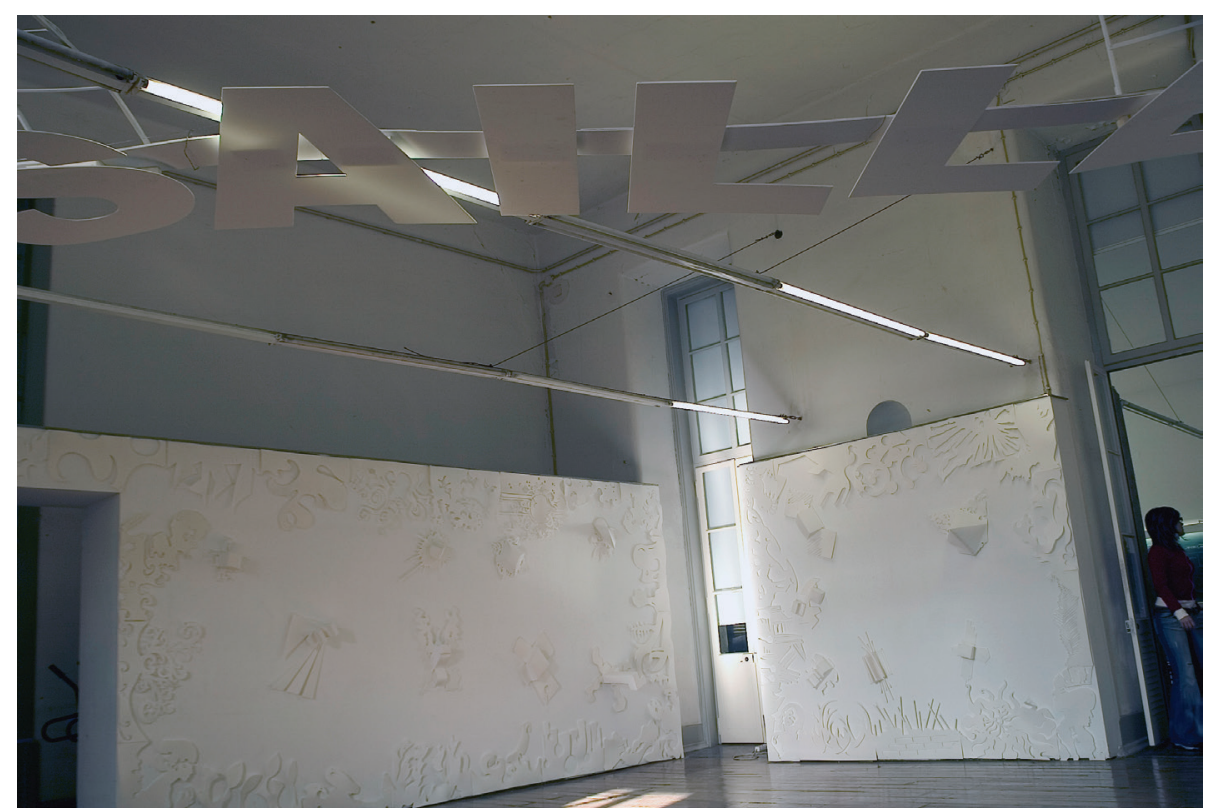

188

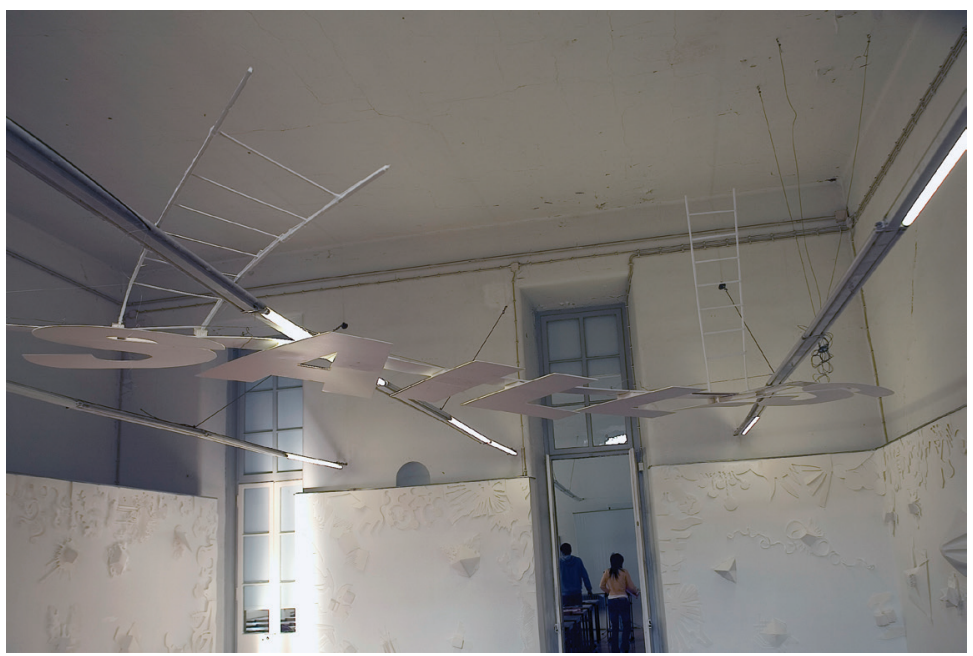




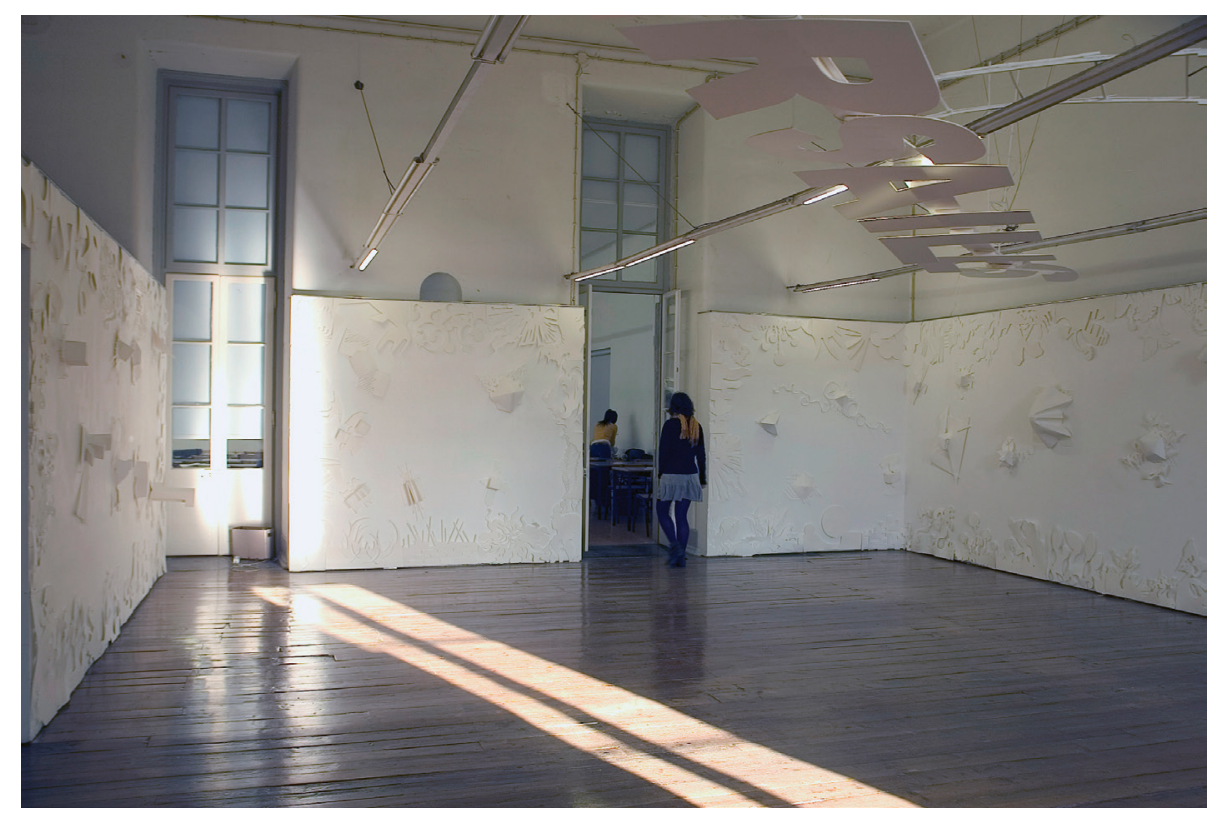

189

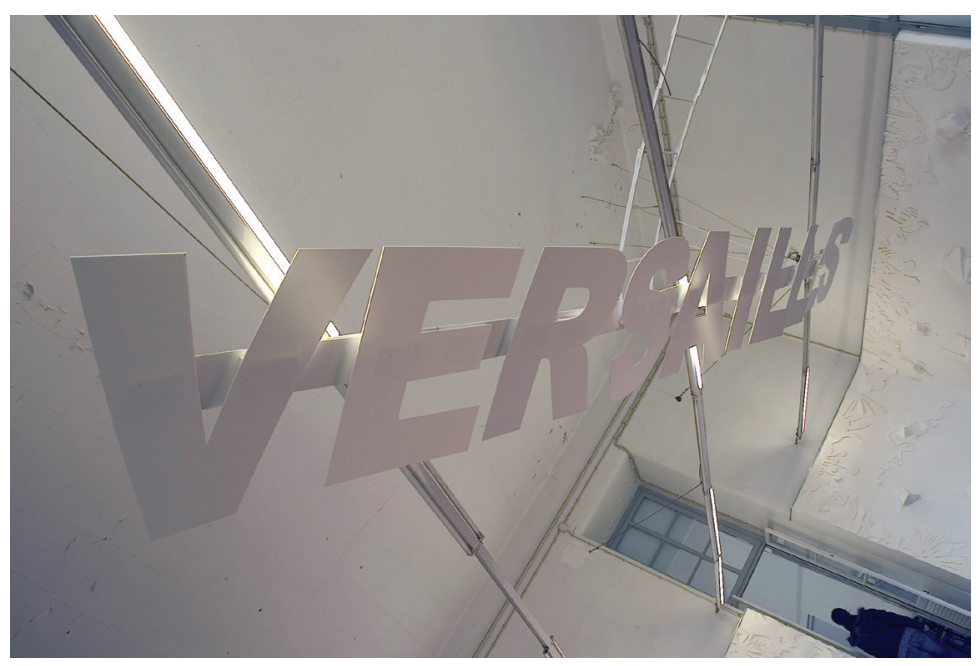




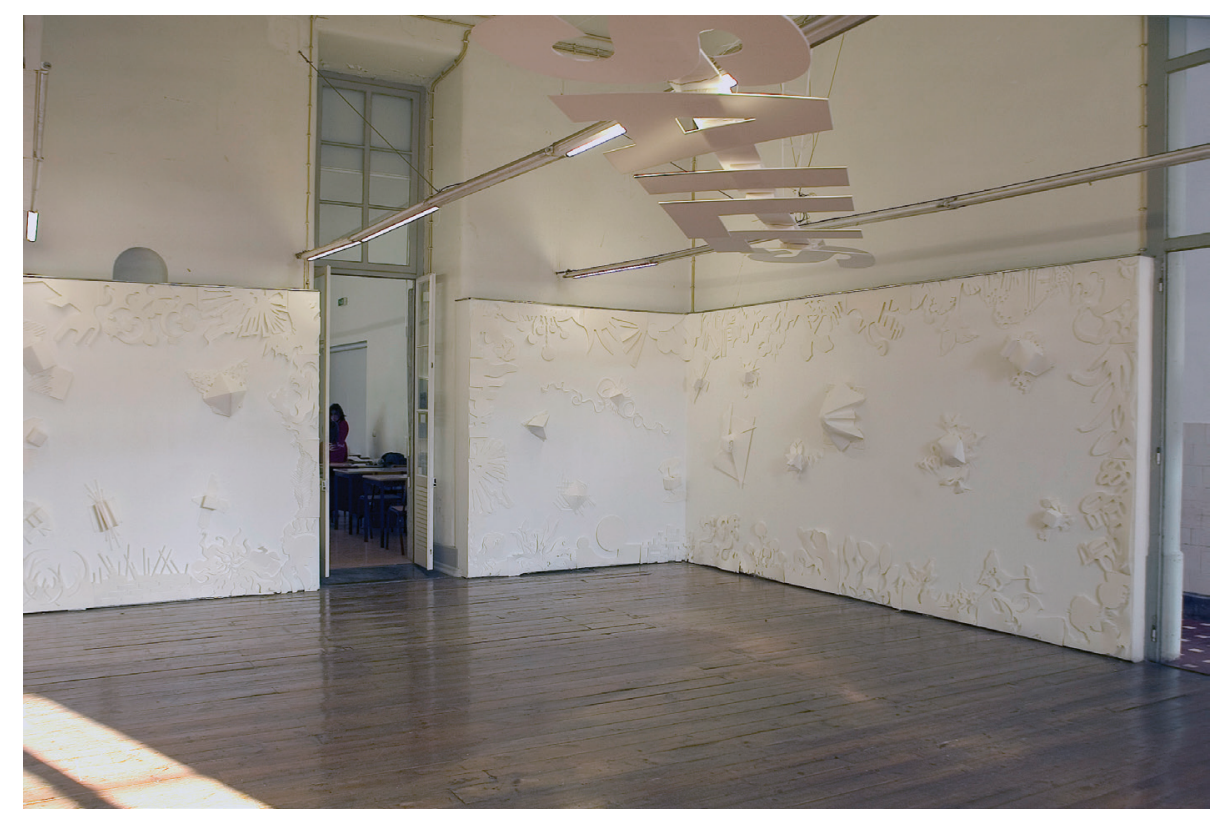

190

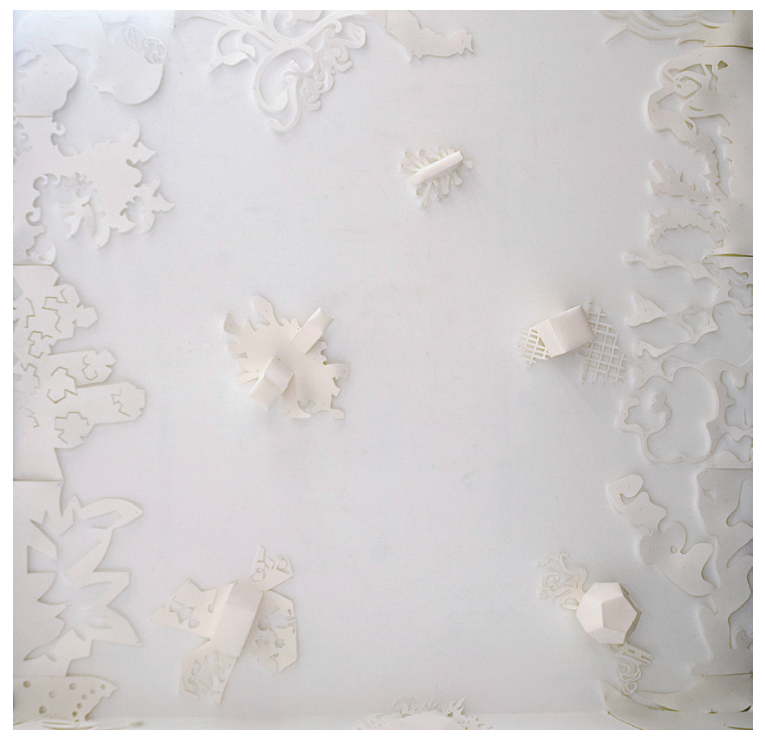



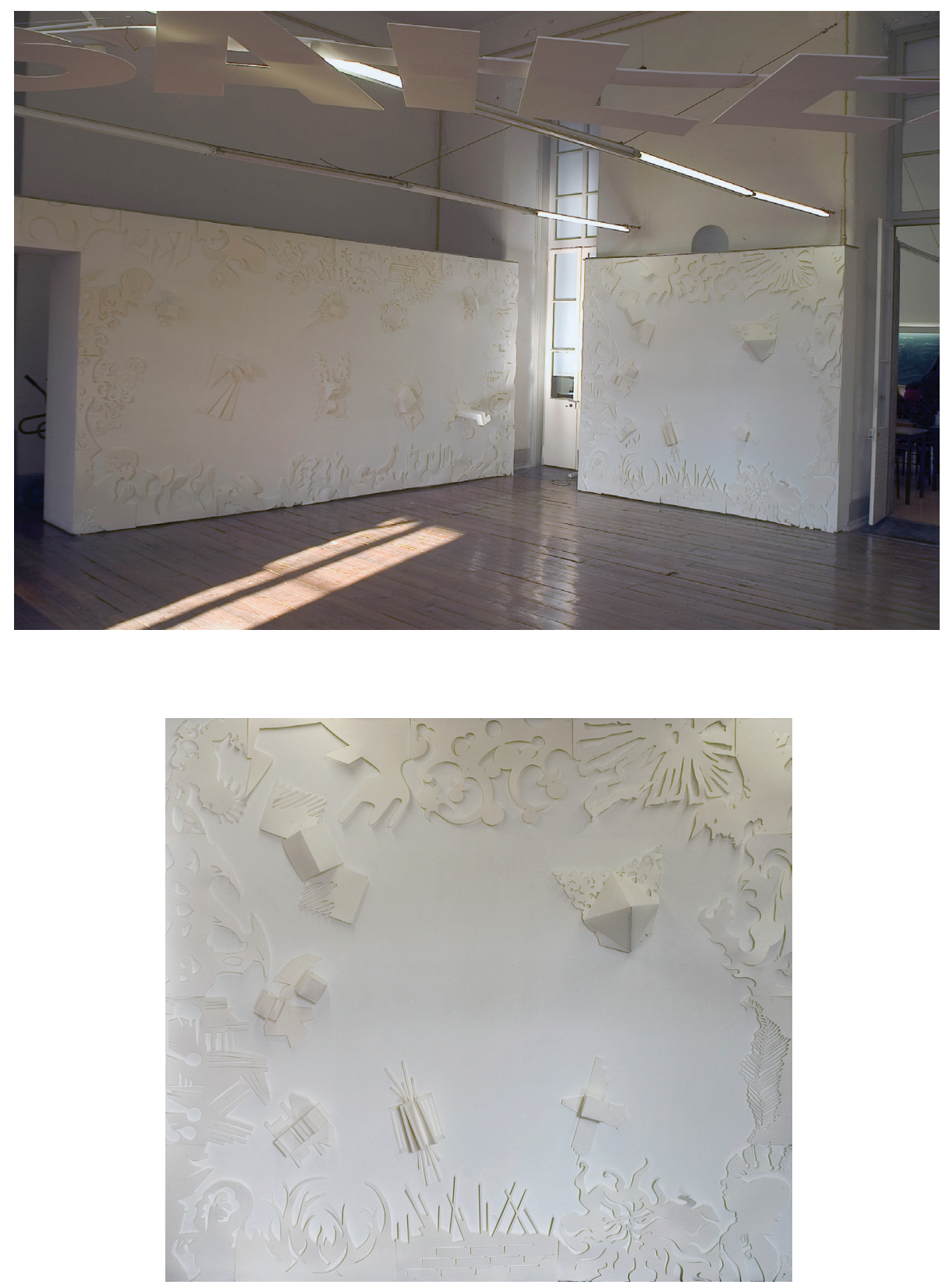


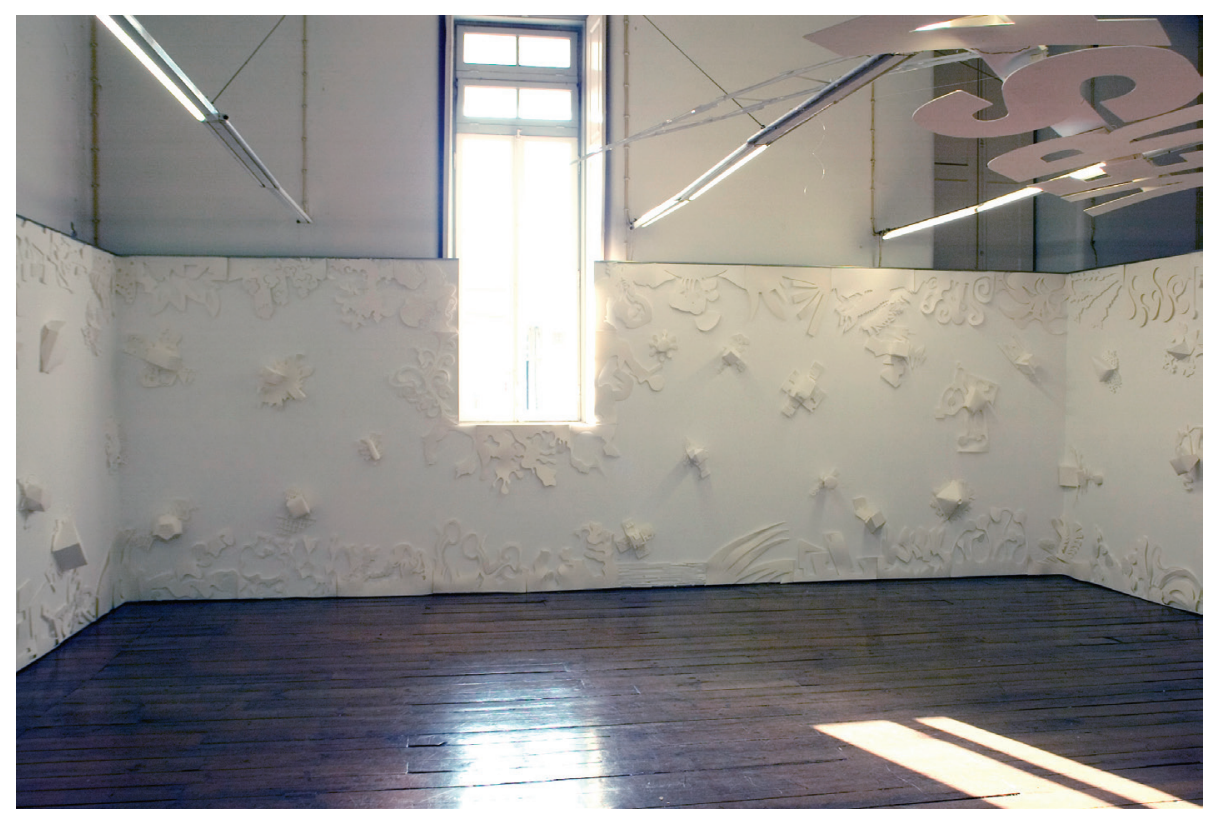

192

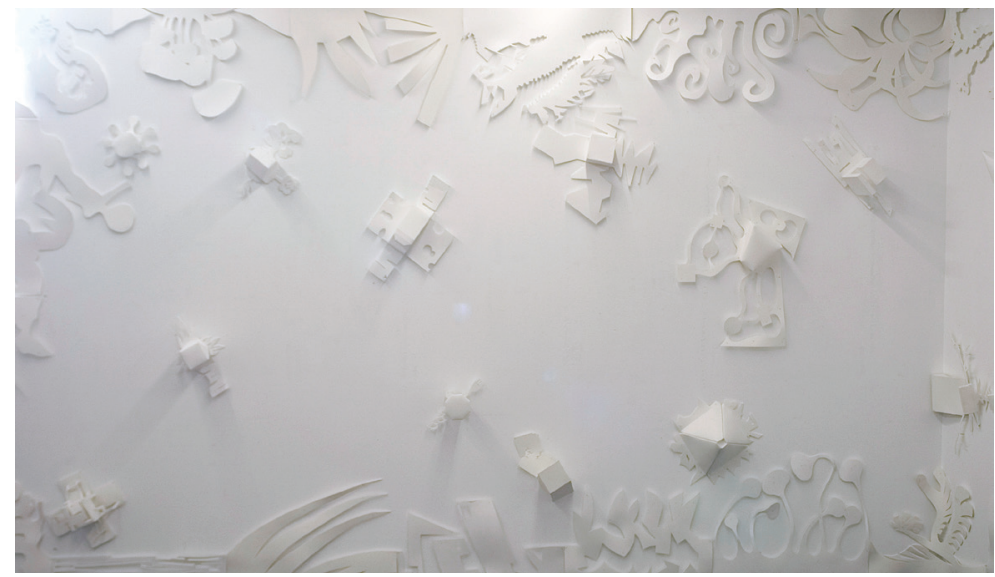



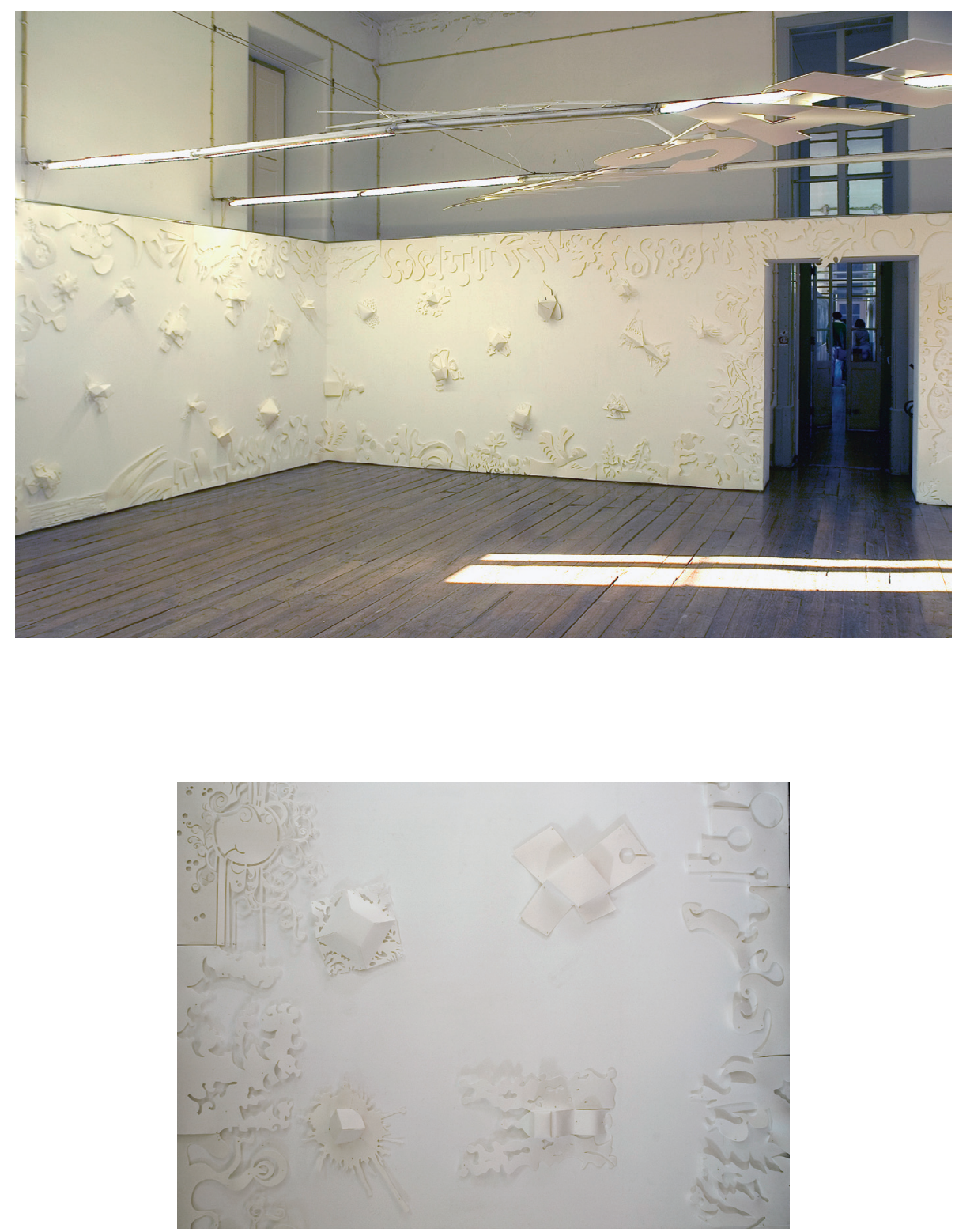


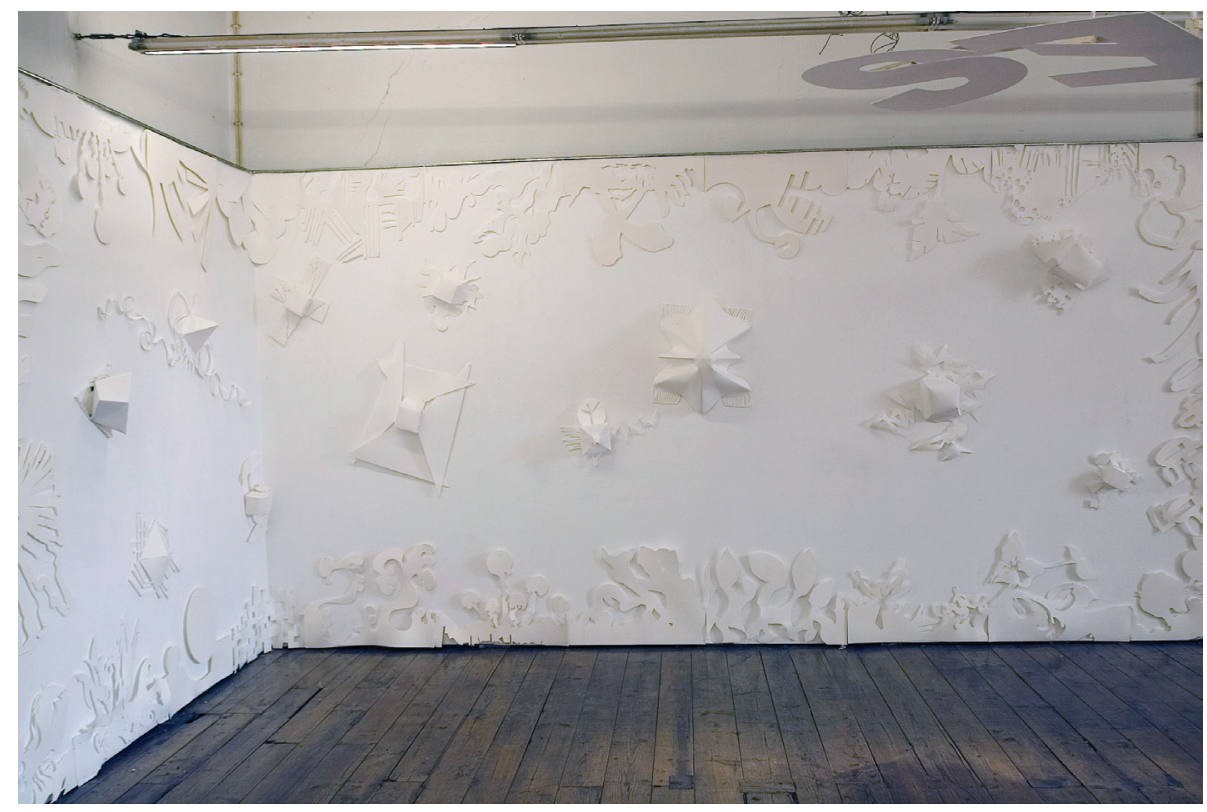

194

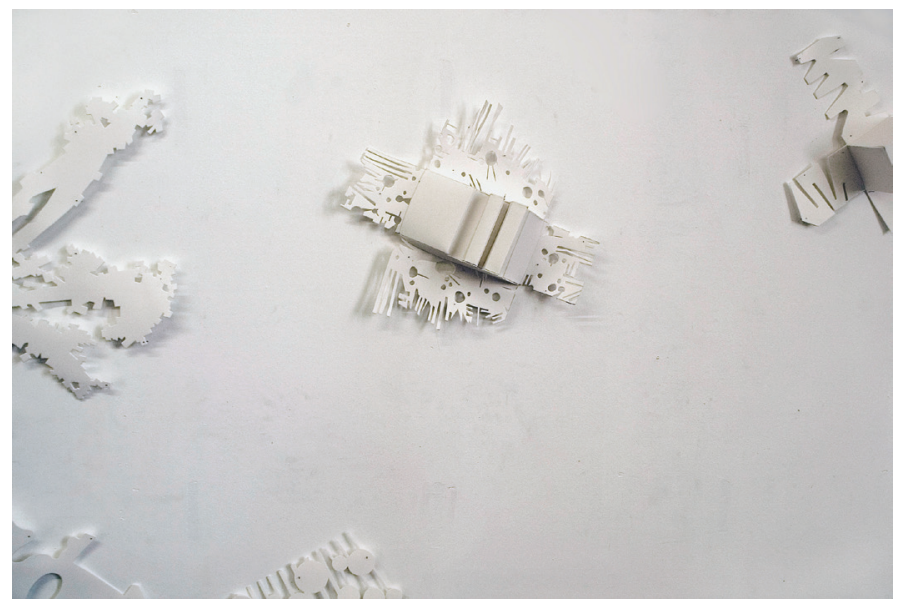



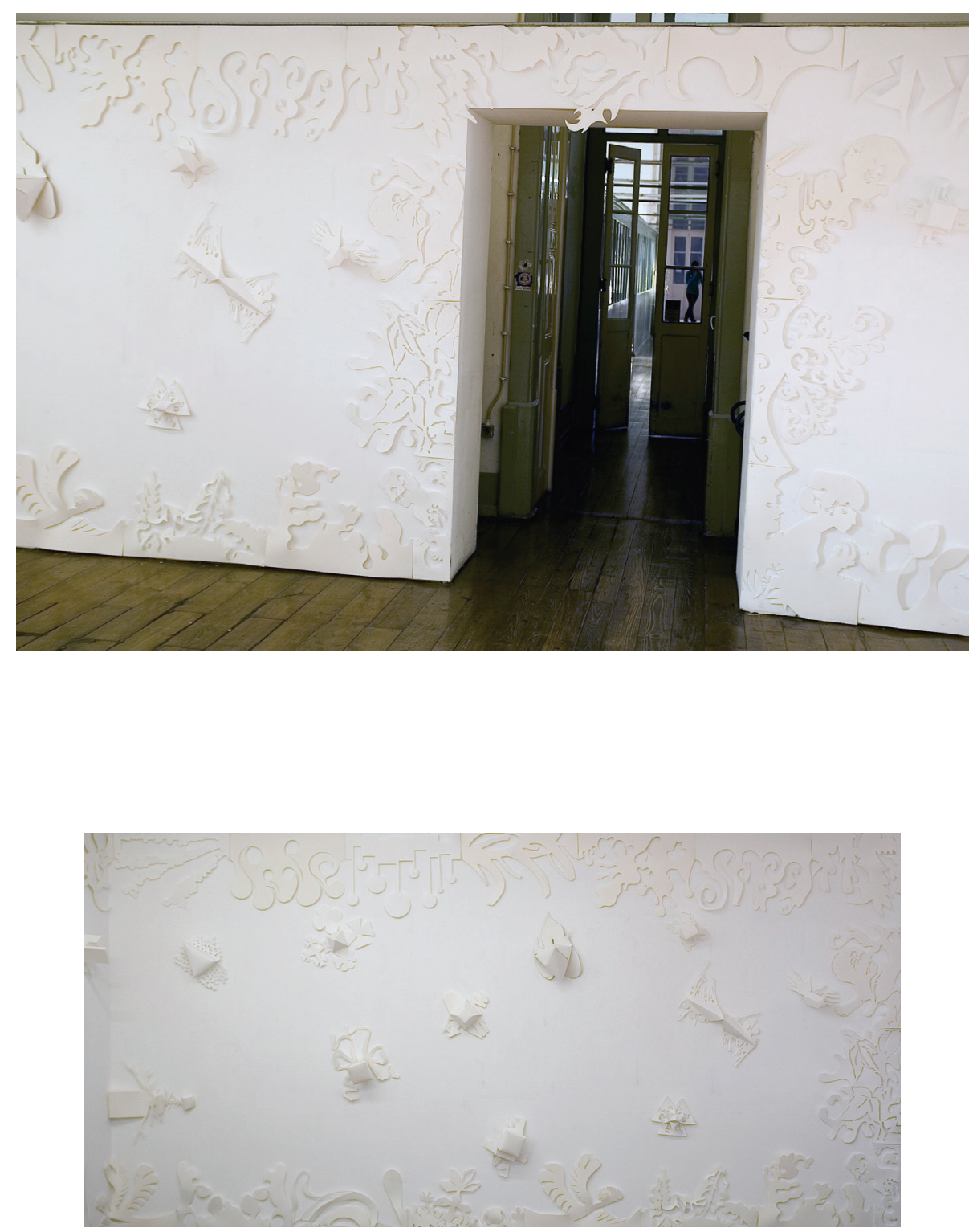
(Página deixada propositadamente em branco) 


\section{A PELE EM RELEVO}

Para esta instalação cada aluno concebia, em cartolina preta, um ou mais módulos, num trabalho colectivo, mas sem diluiçáo de autorias, onde cada parte tem um autor.

No seu todo, funcionava como um padrão de riscas verticais como num papel de parede, mas onde as riscas ganhavam volume, avançando em relevos de expressão variável para o espaço tridimensional.

Esta instalaçáo foi criada para uma das 3 salas do Círculo de Artes Plásticas de Coimbra junto ao jardim da Sereia.

Desde logo, foi determinante para esta instalação a forma como a grande janela para o jardim funcionando como uma quarta parede que abre o espaço, potencialmente de forma ilimitada, numa sala cujo desenho foi conduzido pela própria ideia de perspectiva.

Assim, as riscas verticais criadas pelos alunos e colocadas nas paredes a espaços regulares, acentuam a perspectiva ao mesmo tempo que evidenciam a sua materialidade, na simultaneidade entre a abstração perspética, a metamorfose e a afirmaçáo de tridimesionalidade. E, tudo isto, numa qualidade plástica que evoca o decorativo para afirmar uma dimensão estética essencial. 
(Página deixada propositadamente em branco) 


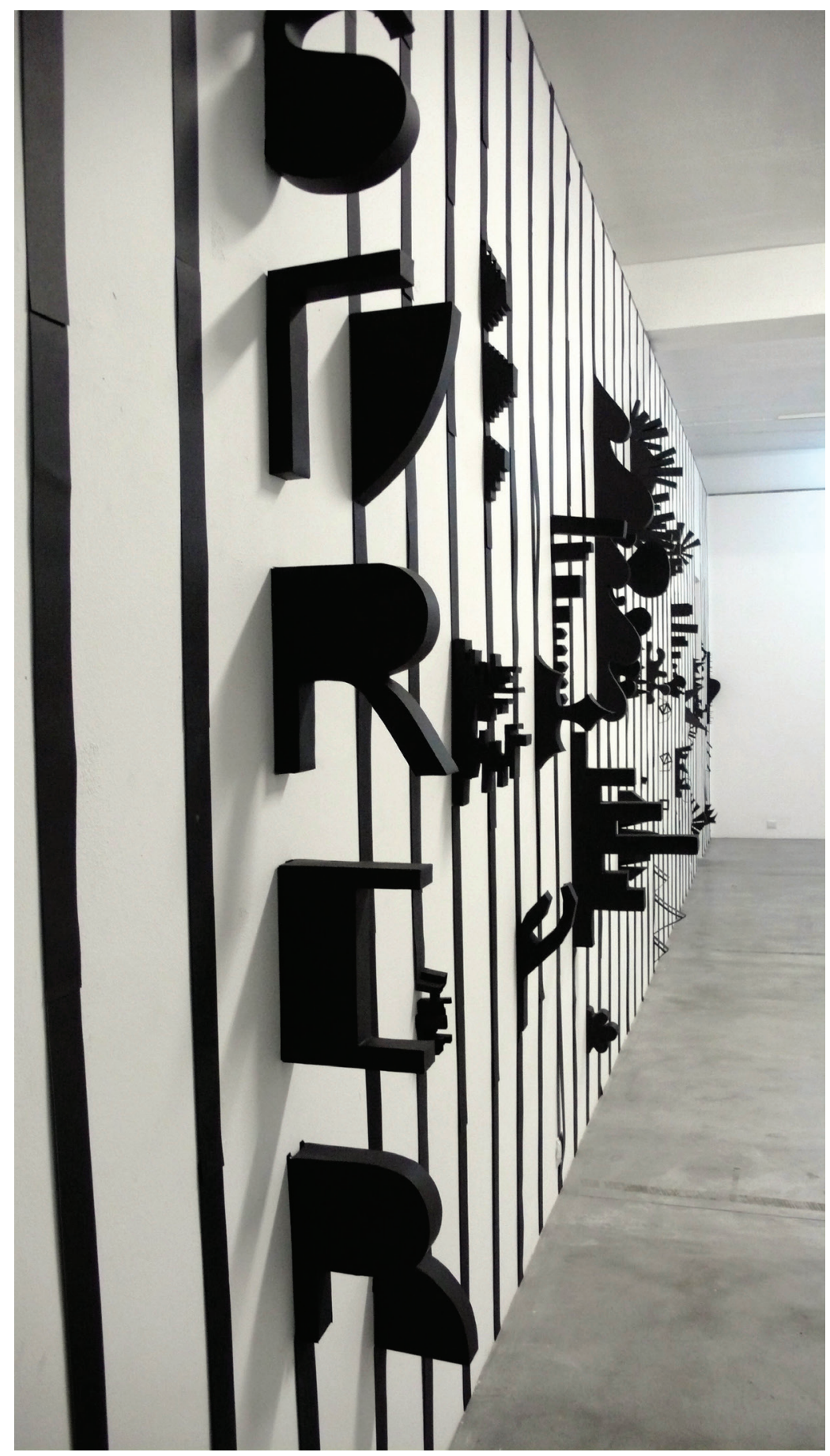




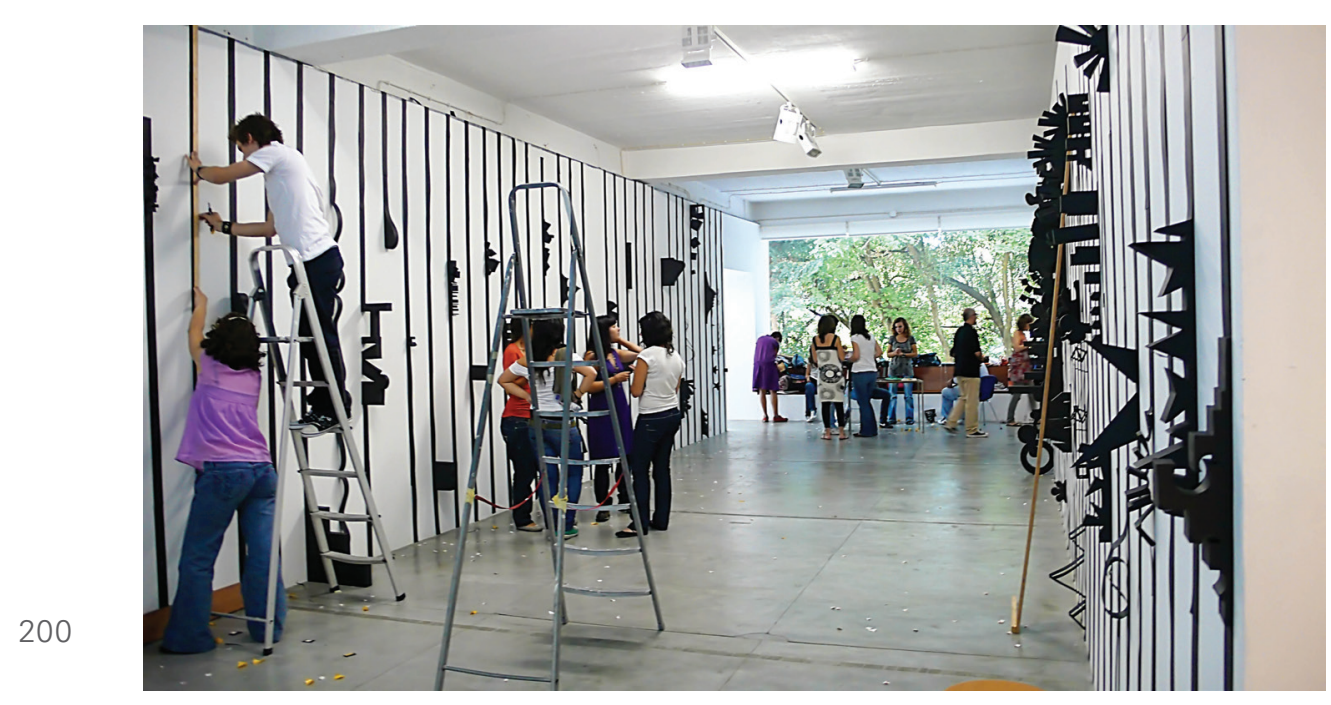




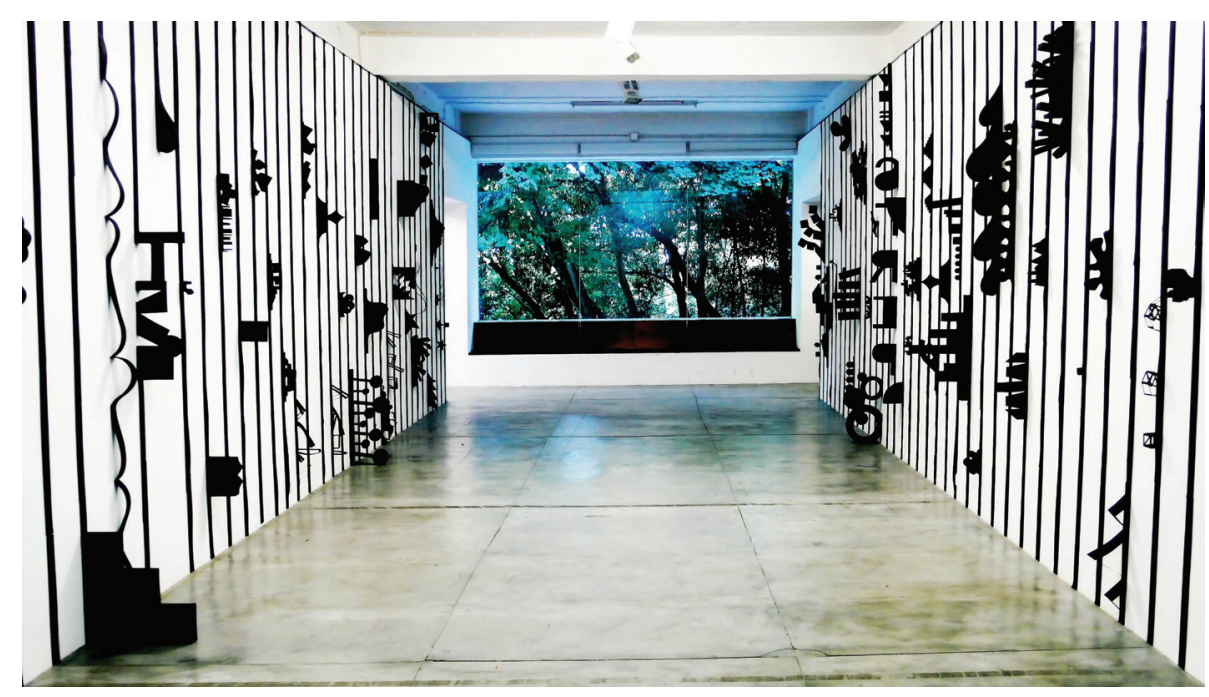

Ana Almeida, Ana Martins, Ana Neto, Ana Santos, Ana Quartilho, Ana Figueiredo, Andreia Monteiro, Bruna Ferreira, Catia Azenha, Christina Batista, Christopher Gaspar, Claudete Neves, Daniela Santos, Daniela Melo, David Sarmento, Dinis Encarnacao, Diogo Lopes, Diogo Cruz, Diogo Pereira, Eduardo Mota, Eduardo Nascimento, Elisa Silva, Filipe Madeira, Filipe Carvalho, Francisco Oliveira, Frederico Martinho, Gilson Varela, Ines Ribeiro, Ines Dias, Isabel Rodrigues, Ivo Azevedo, Jan-Vincent Bersier, Jaqueline Soeiro, Joana Pereira, Joana Oliveira, Joao Monteiro, Joao Pina, Jose Almeida E Silva, Lia Antunes, Liliana Bispo, Luís Santos, Luis Marques, Mafalda Mauricio, Marcia Xavier, Margarida Ferreira, Maria Silva, Maria Correia, Maria Manuel Ponte, Maria Miguel Ponte, Maria Rita Serra E Silva, Mariana Roque, Mariana Palhoto, Mario Carvalhal, Maura Silva, Nuno Sequeiros, Nuno Pestana, Pedro Matos, Pedro Pereira, Raquel Bernardino, Regina Santos, Rui Pinto, Sara Jorge, Sara Bronze, Sara Figueiredo, Sara Amaral, Sofia Cunha, Soraia Fernandes, Tony Coelho, Vania Correia, Vasco Alves, Vitor Almeida. 

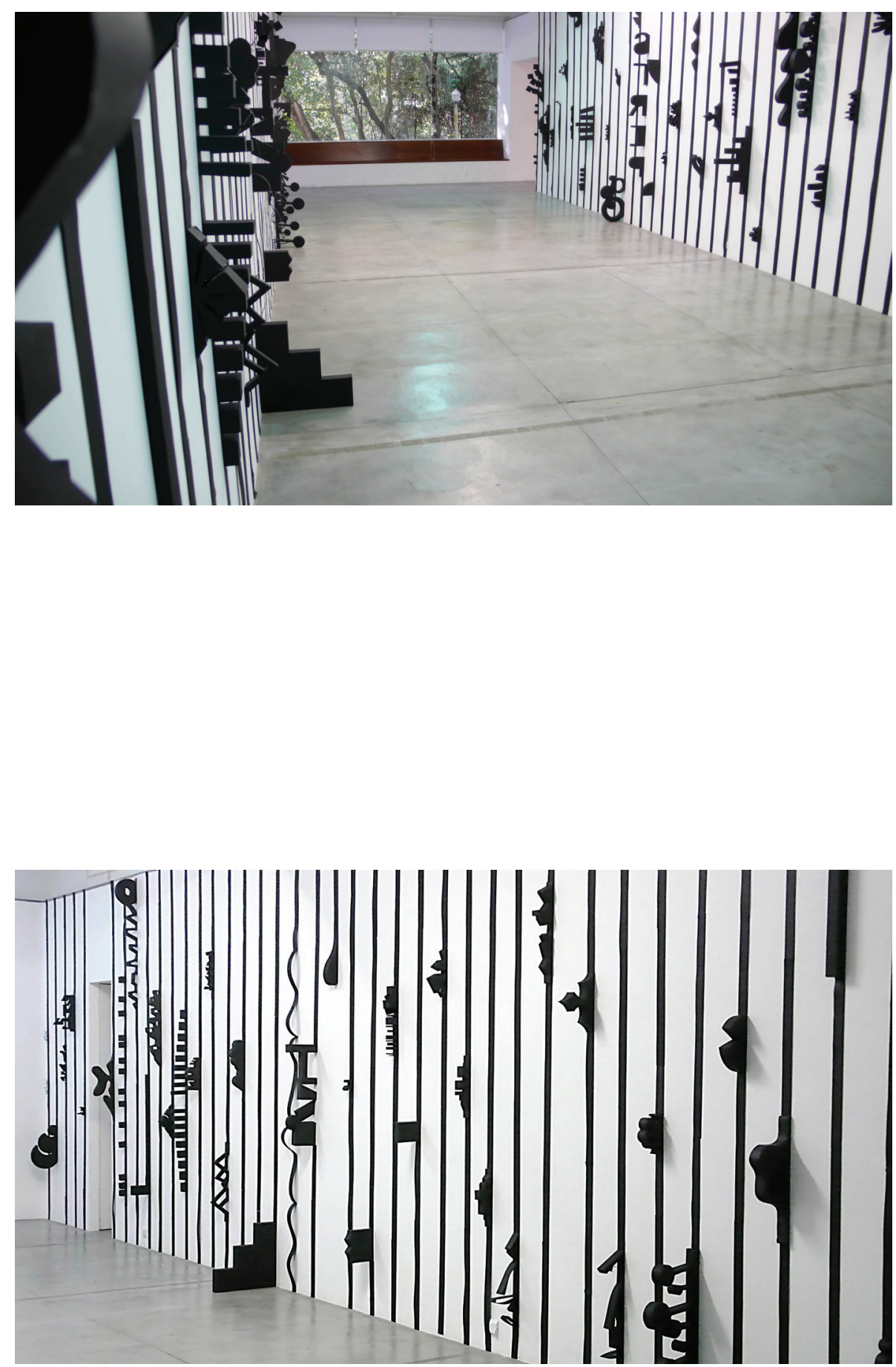

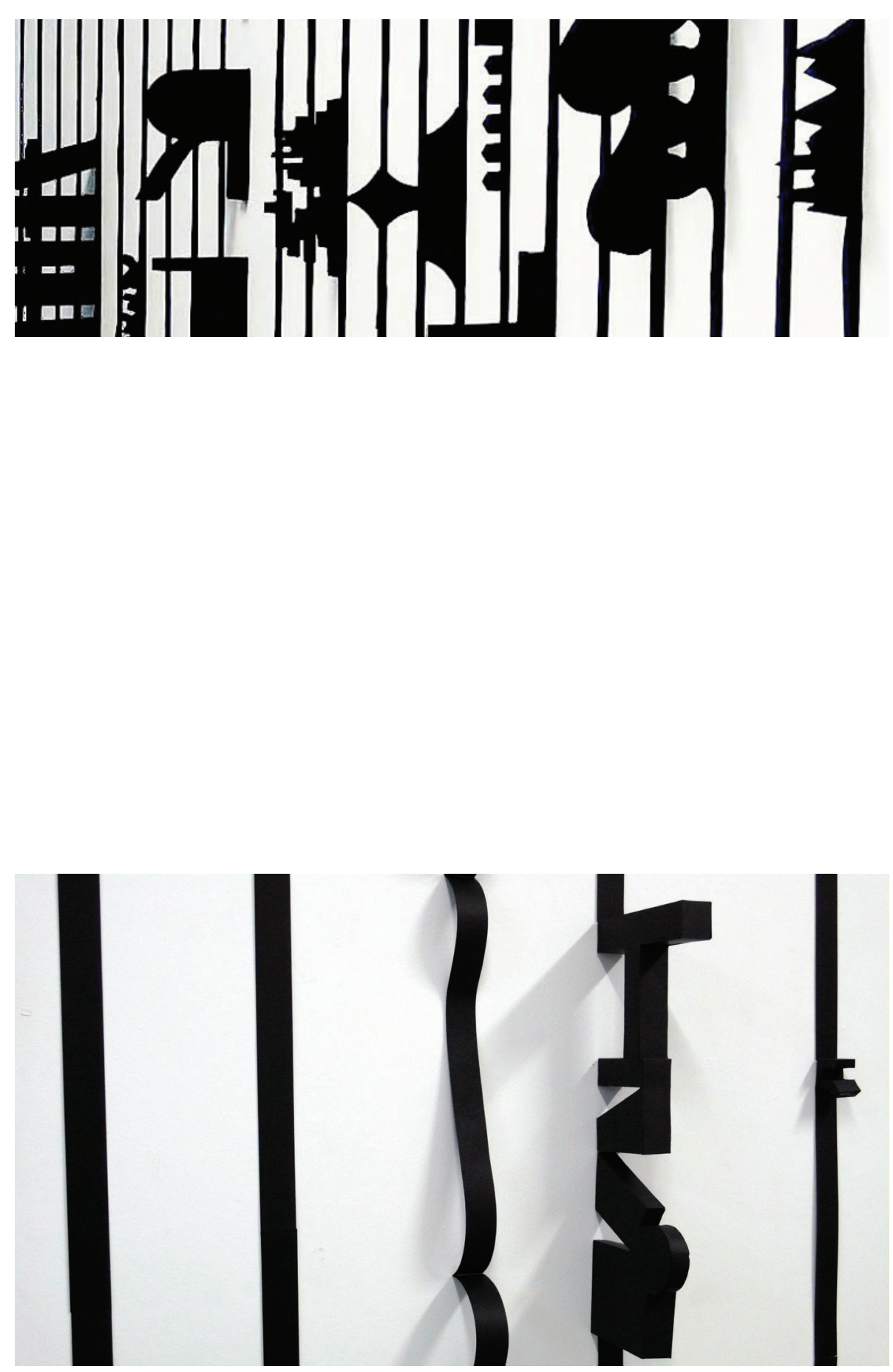
(Página deixada propositadamente em branco) 
Aqui os alunos partiram da potencialidade plástica das nuvens.

Nuvens enquanto informalidade, mas ao mesmo tempo lugar de projeção de todas as formas (como quem reconhece nas nuvens formas de animais, objetos, pessoas).

Nuvens enquanto imagem de imponderabilidade, nuvens que se desfazem, castelos nas nuvens... nuvens como ponto de partida para a imaginação arquitetónica.

Sendo desafiados a imaginar construções nas nuvens, também foram desafiados à contaminação mútua entre a materialidade do edificado e a imponderabilidade das ideias.

De forma análoga à relação entre a materialidade de uma construção e a imaterialidade de um projecto, aqui se parte da bidimensionalidade de uma superfície, lugar sem dimensão, mas onde todas as dimensôes se poderão projectar, para a gestaçóes de volumetrias. Mas estas volumetrias mantém uma forte tensão com a bidimensionalidade a partir da qual são geradas. Formas fixadas num momento de metamorfose num cadinho onde as relações formais e conceptuais se diluem.

António Olaio 
(Página deixada propositadamente em branco) 

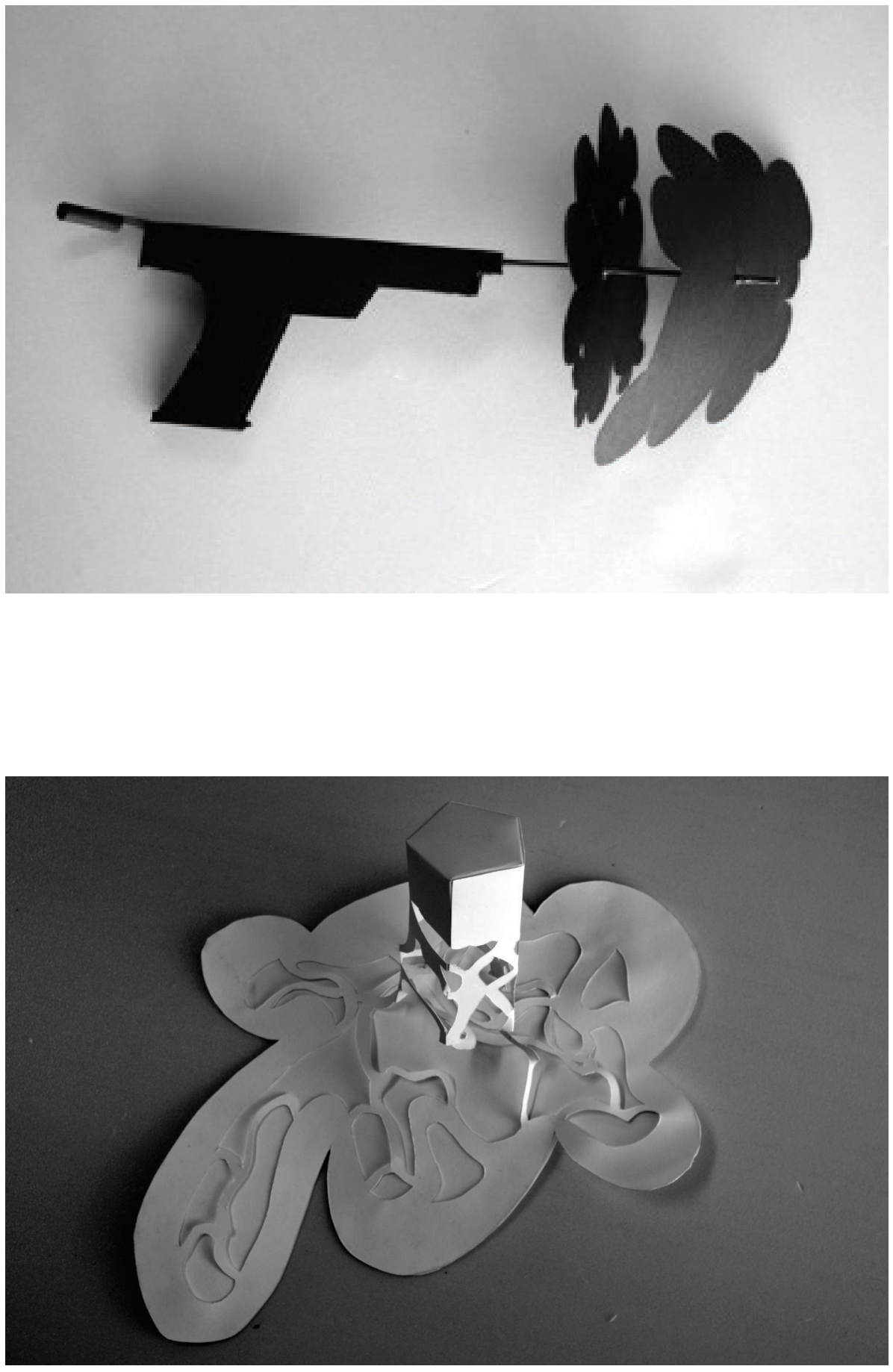

Martinho Araújo, Henrique Pereira 

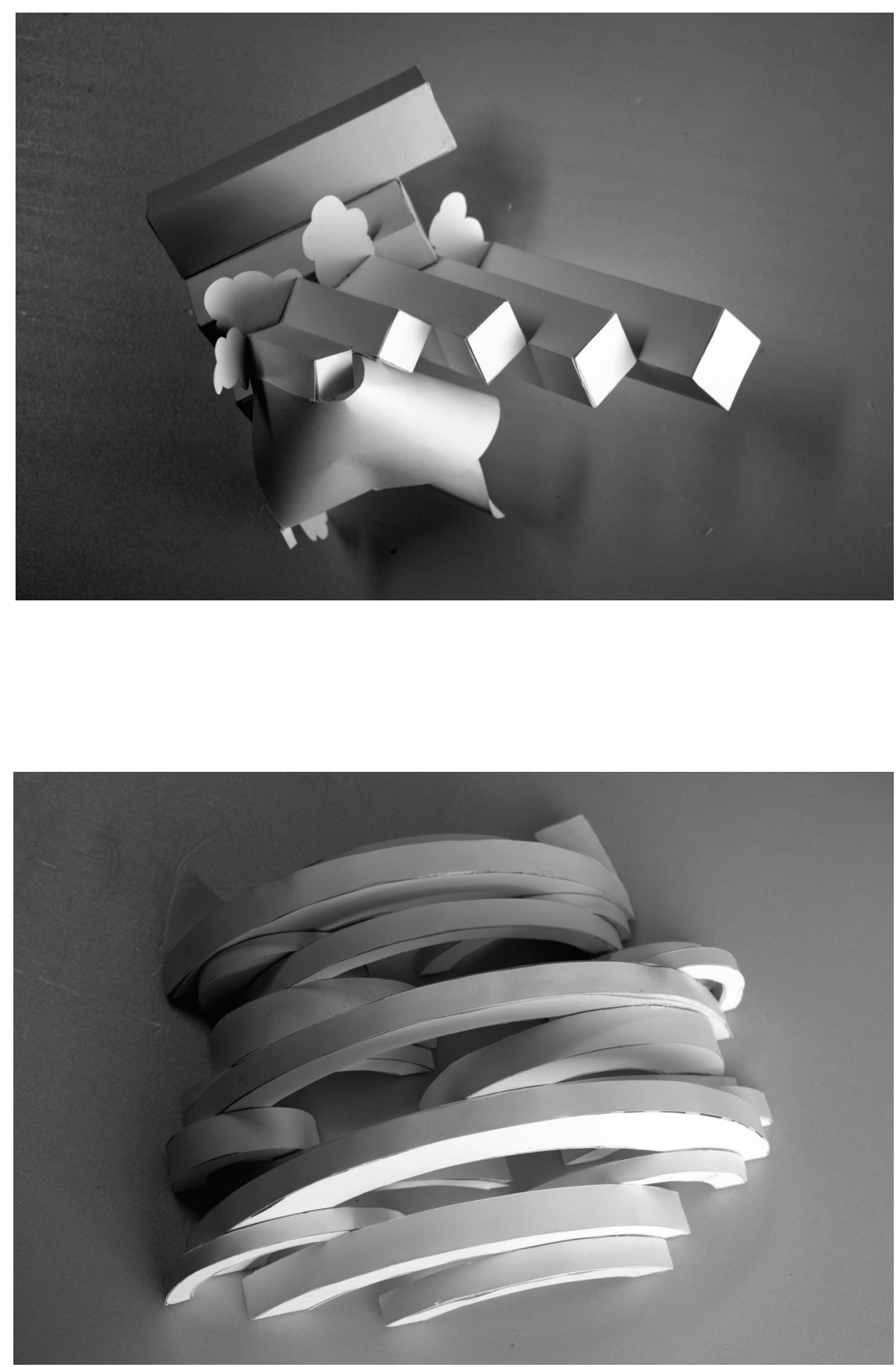

Waldmar Pereira, João Carlos Mendes 

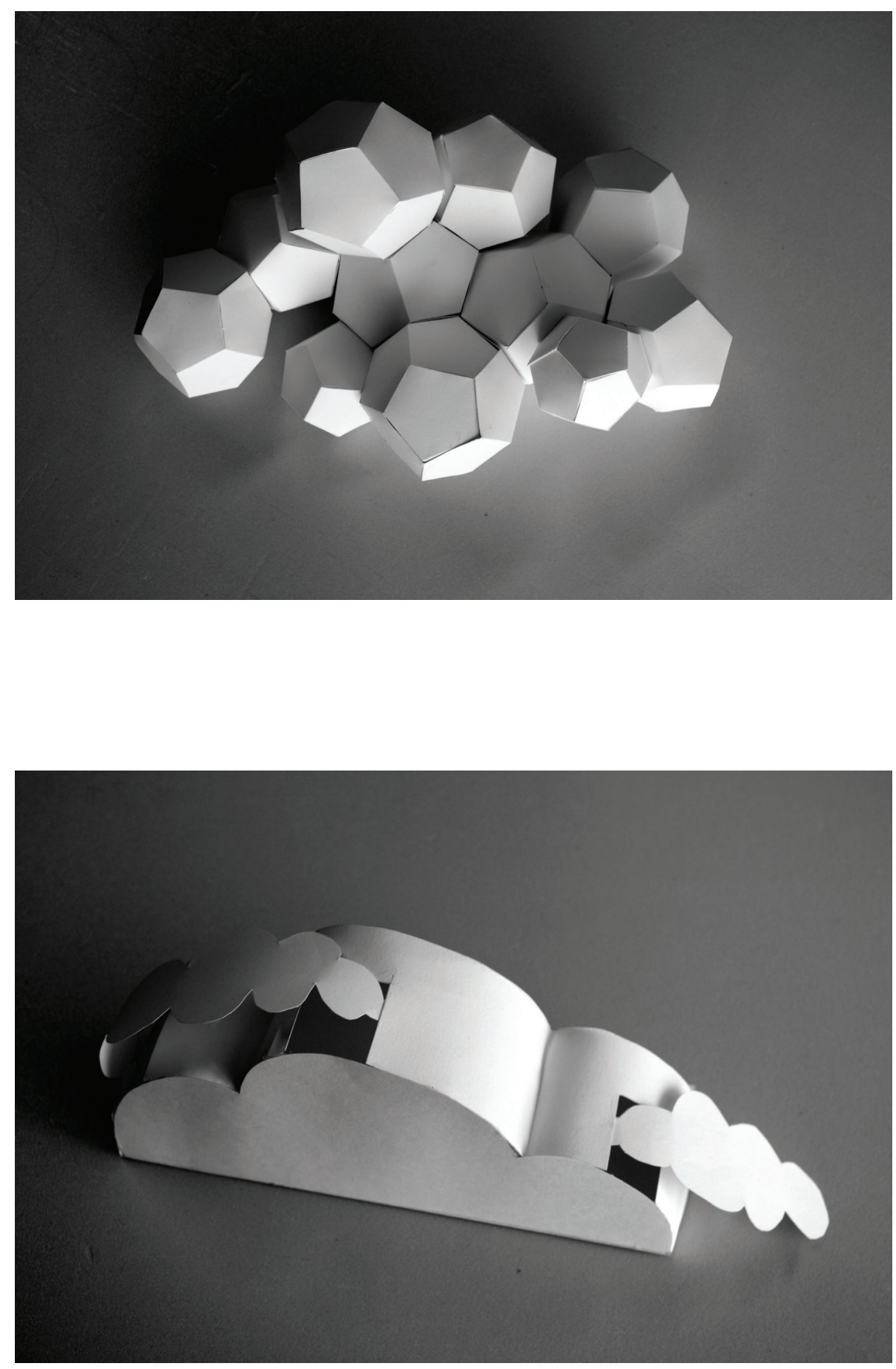

Pedro Grilo, Marlene David 


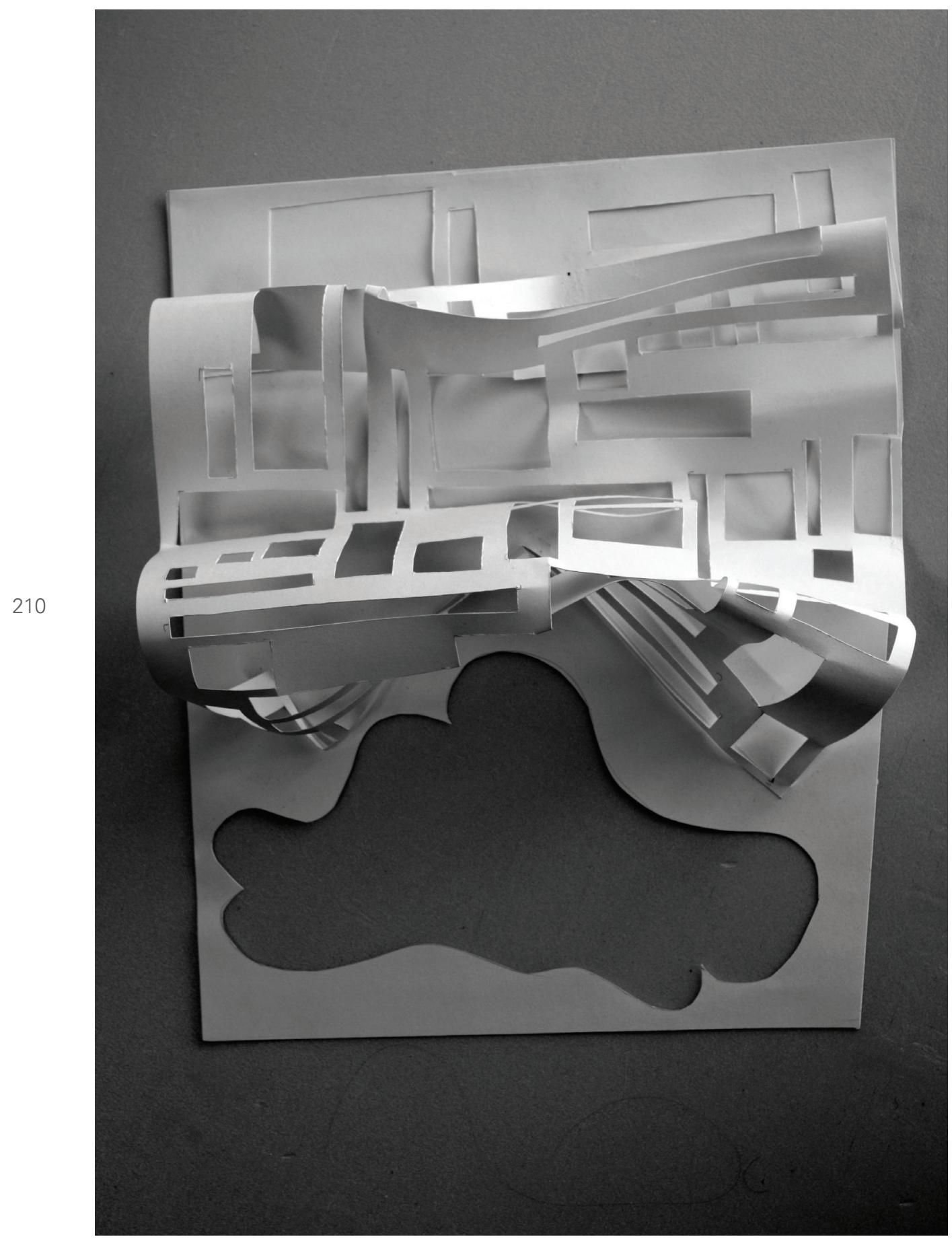

Inês Barreto 

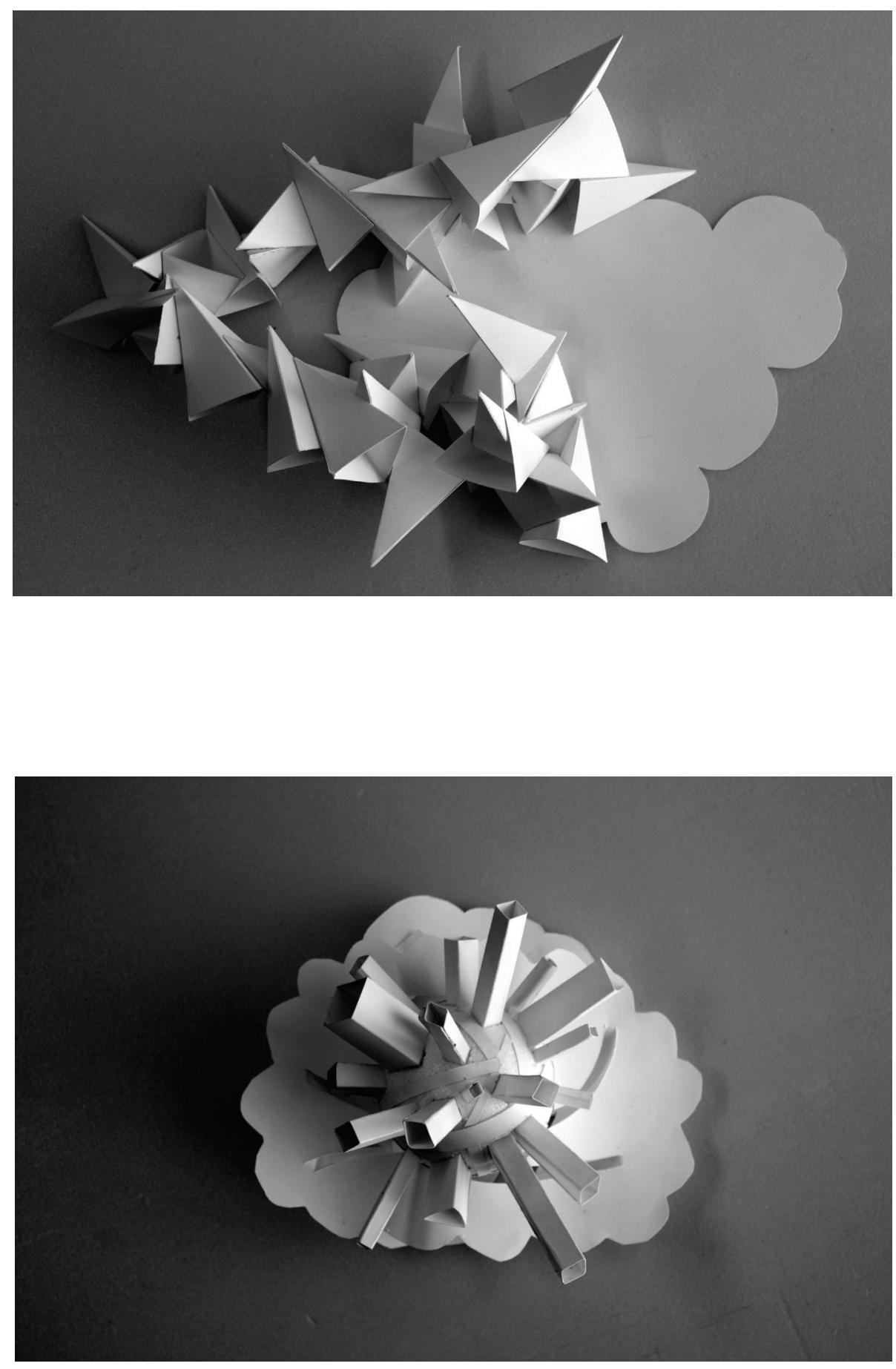

Eunice Silva, Michael Gonçalves 

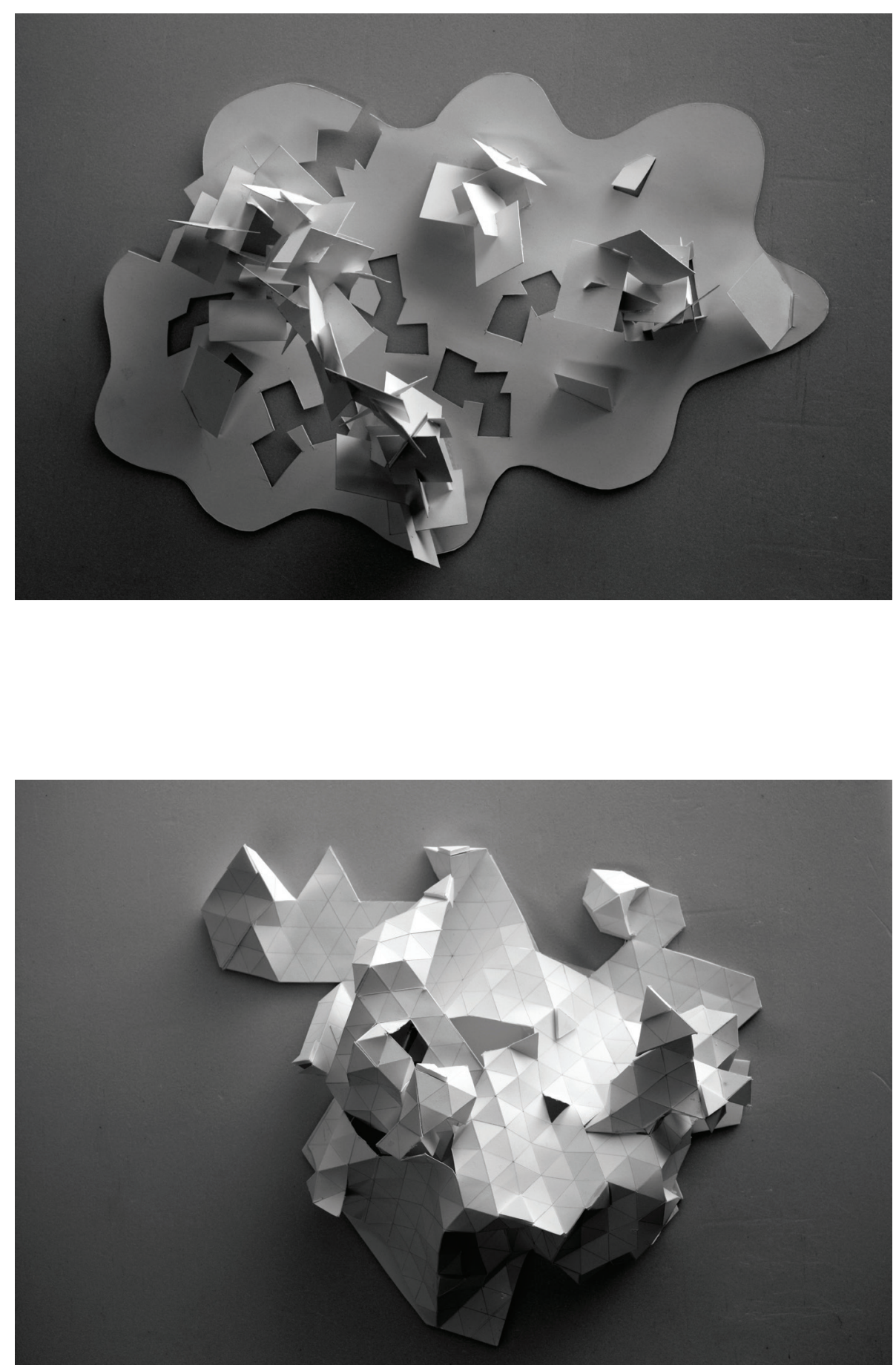

Duarte Pereira, Marco Costa 

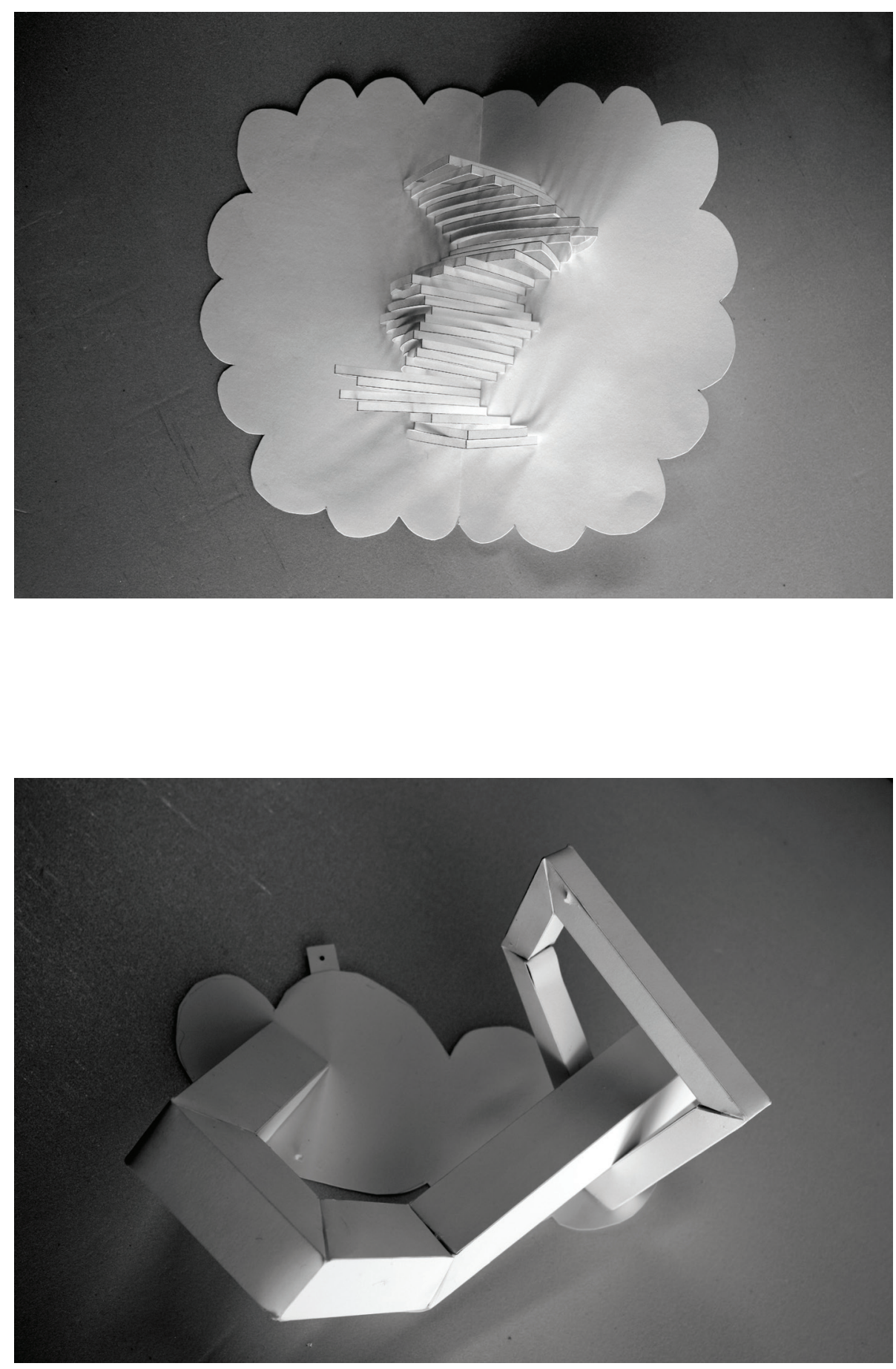

Miriam Queirós, Jorge Gomes 

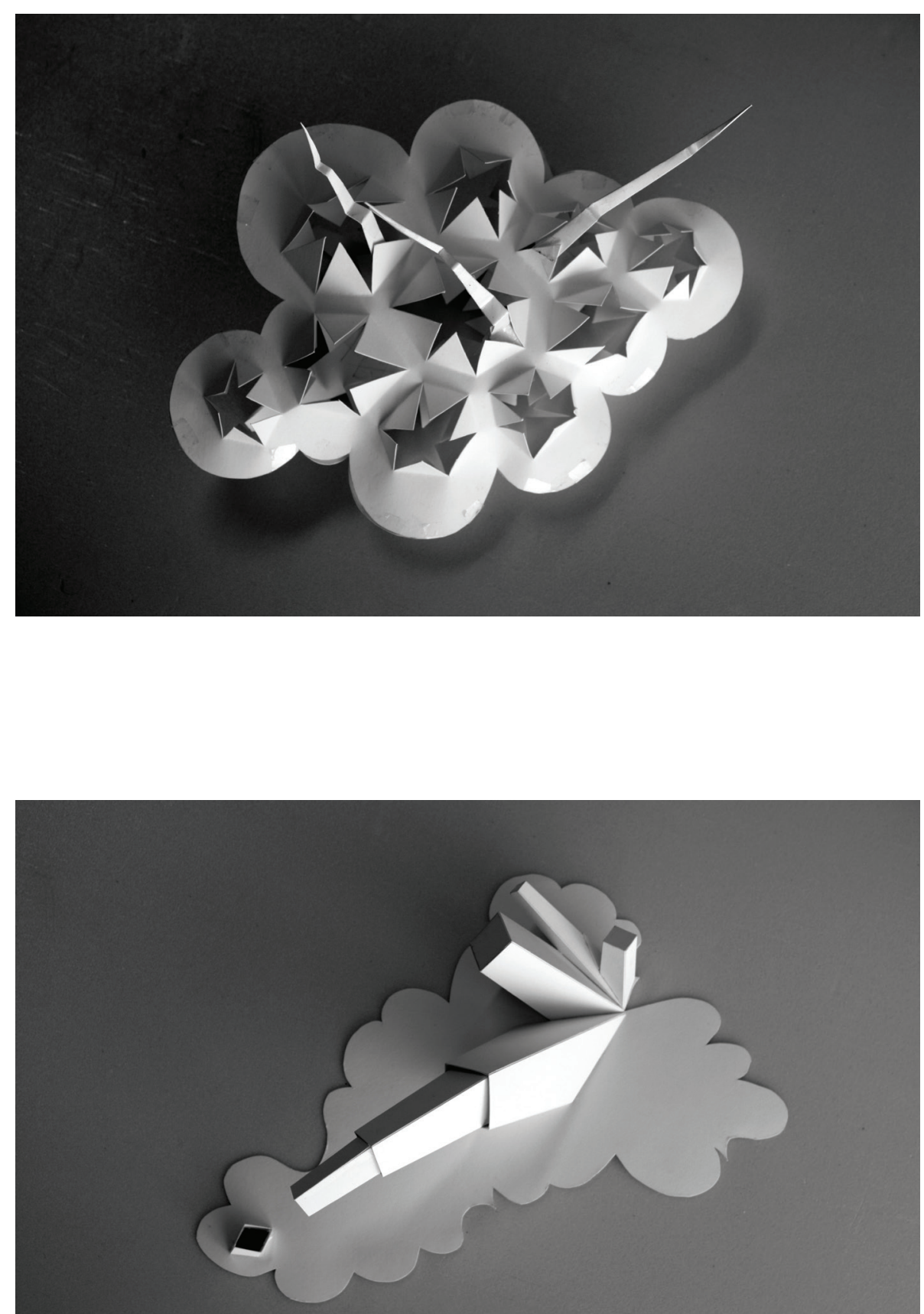

David Jorge, Micael Soares 


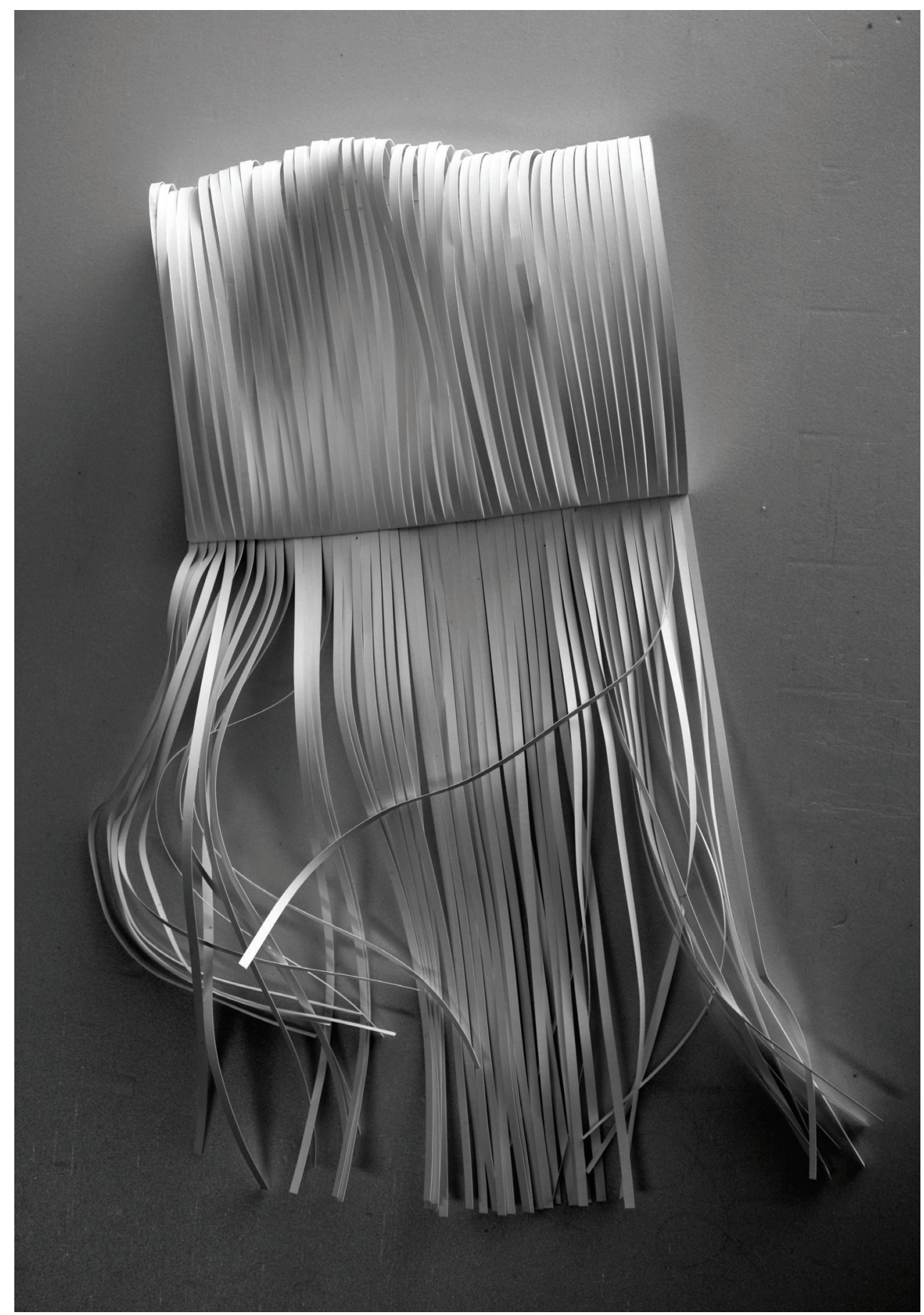

Juliana Teixeira 

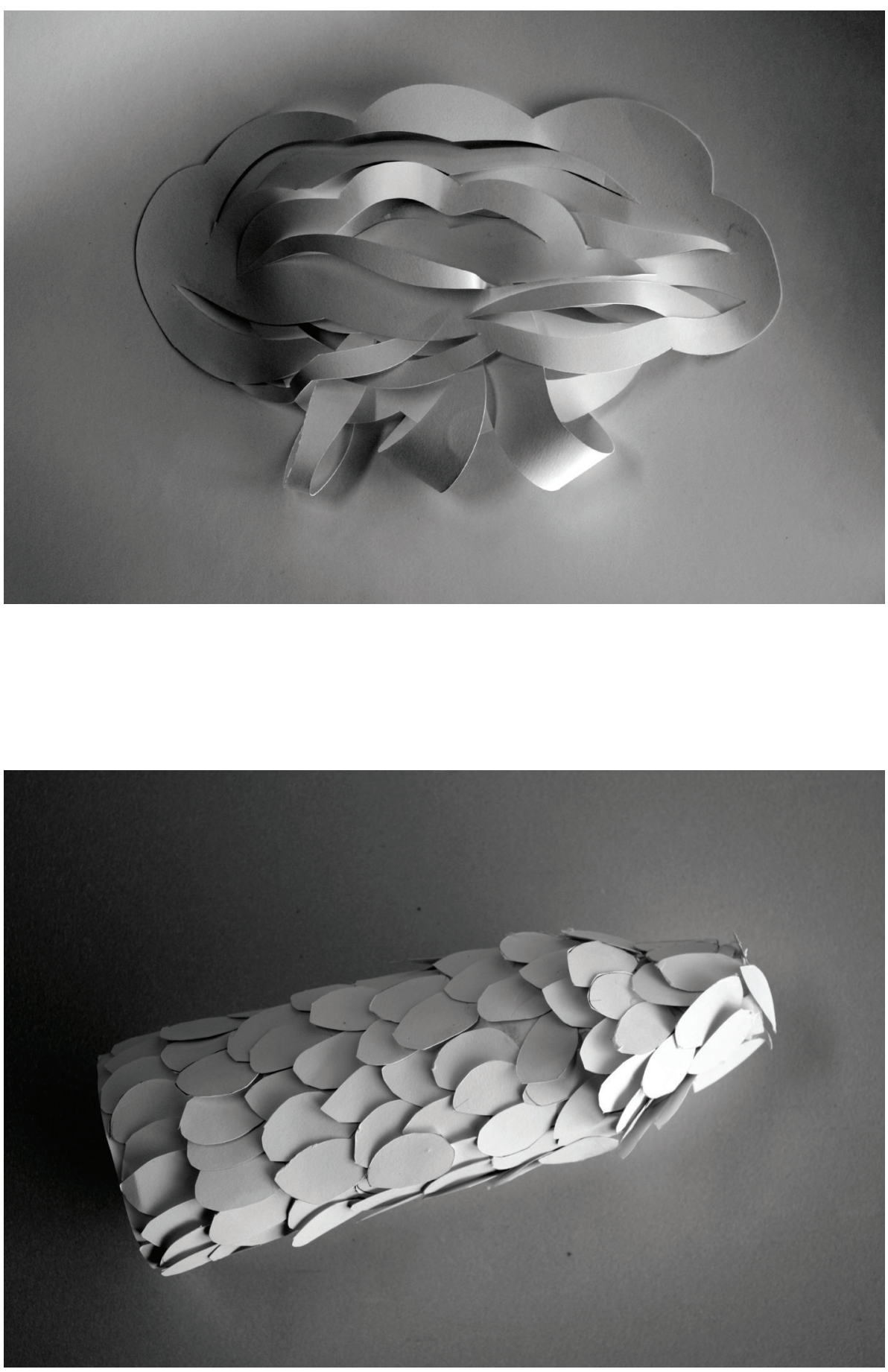

Suellen Costa, Diogo Faria 


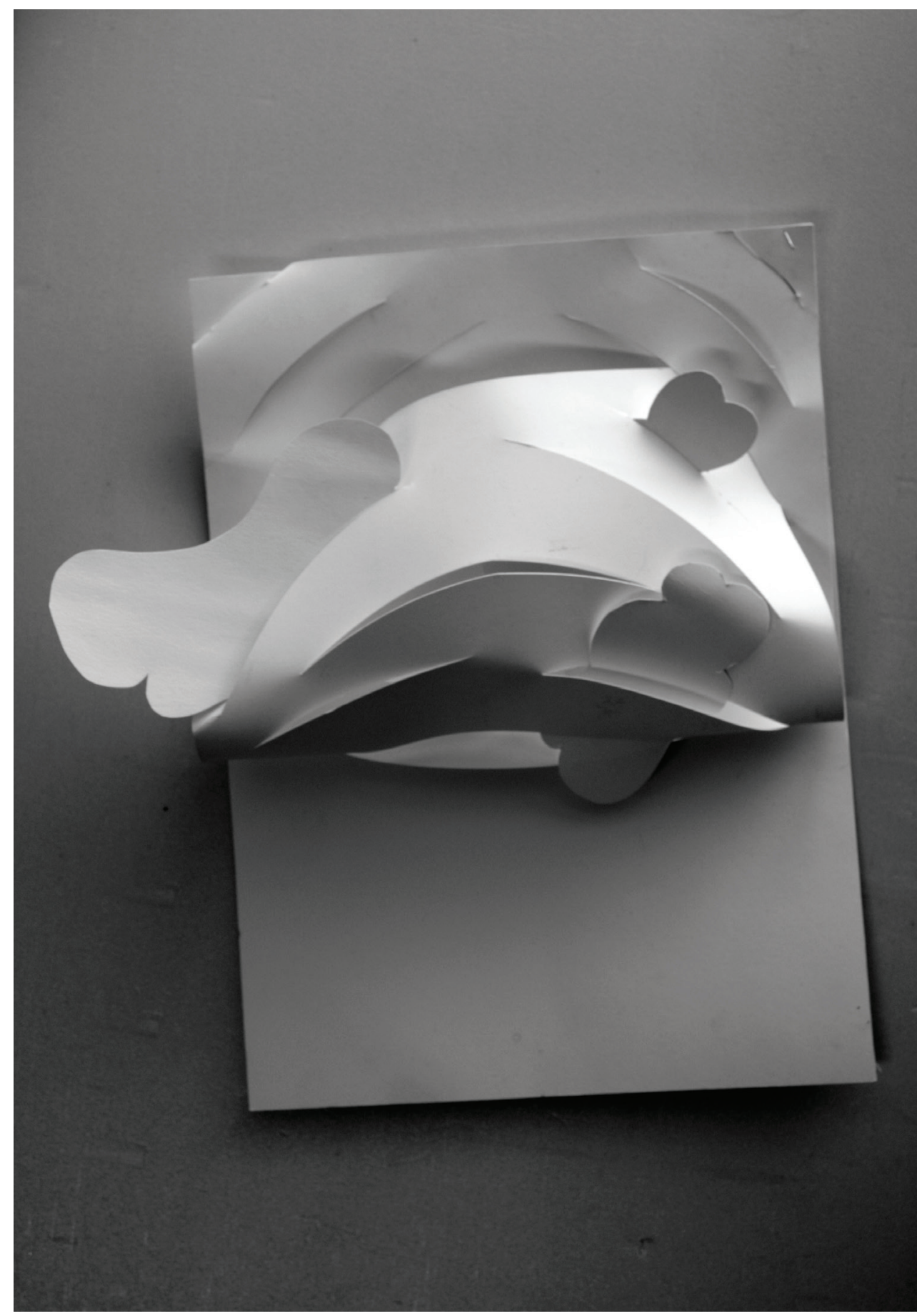

Manuel Rama 


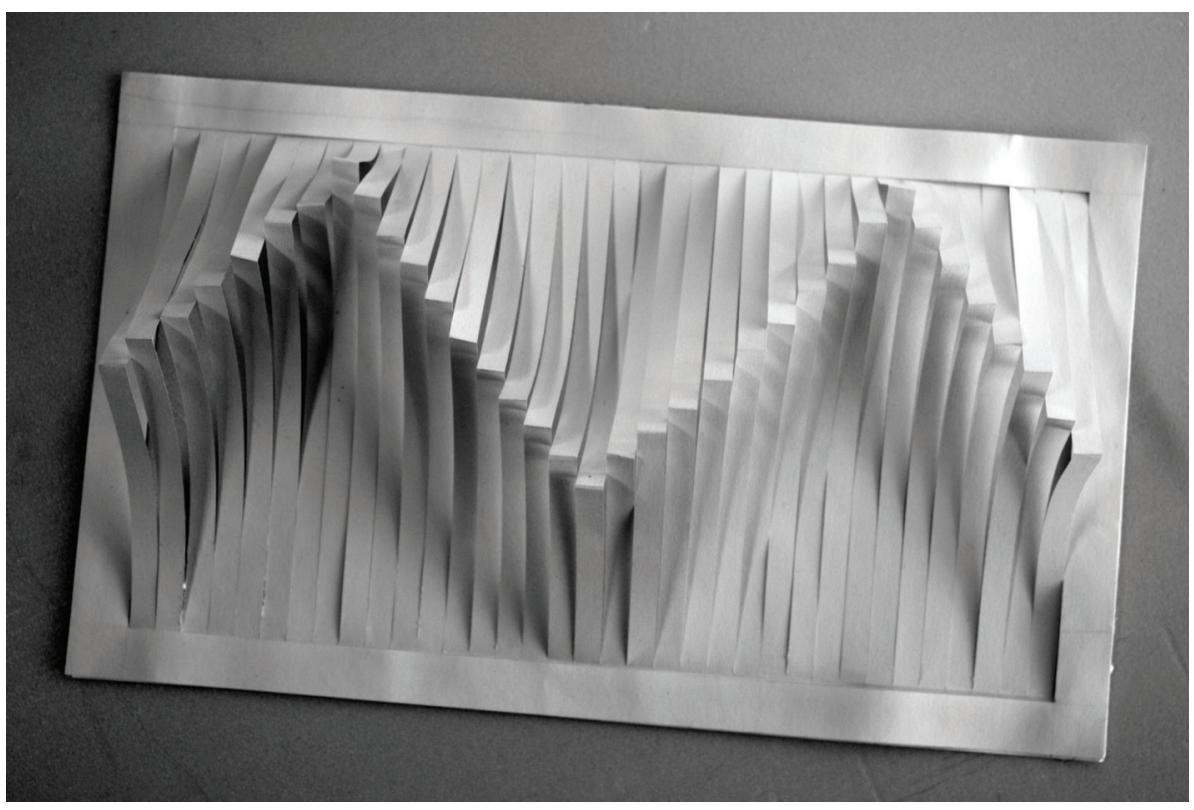

218

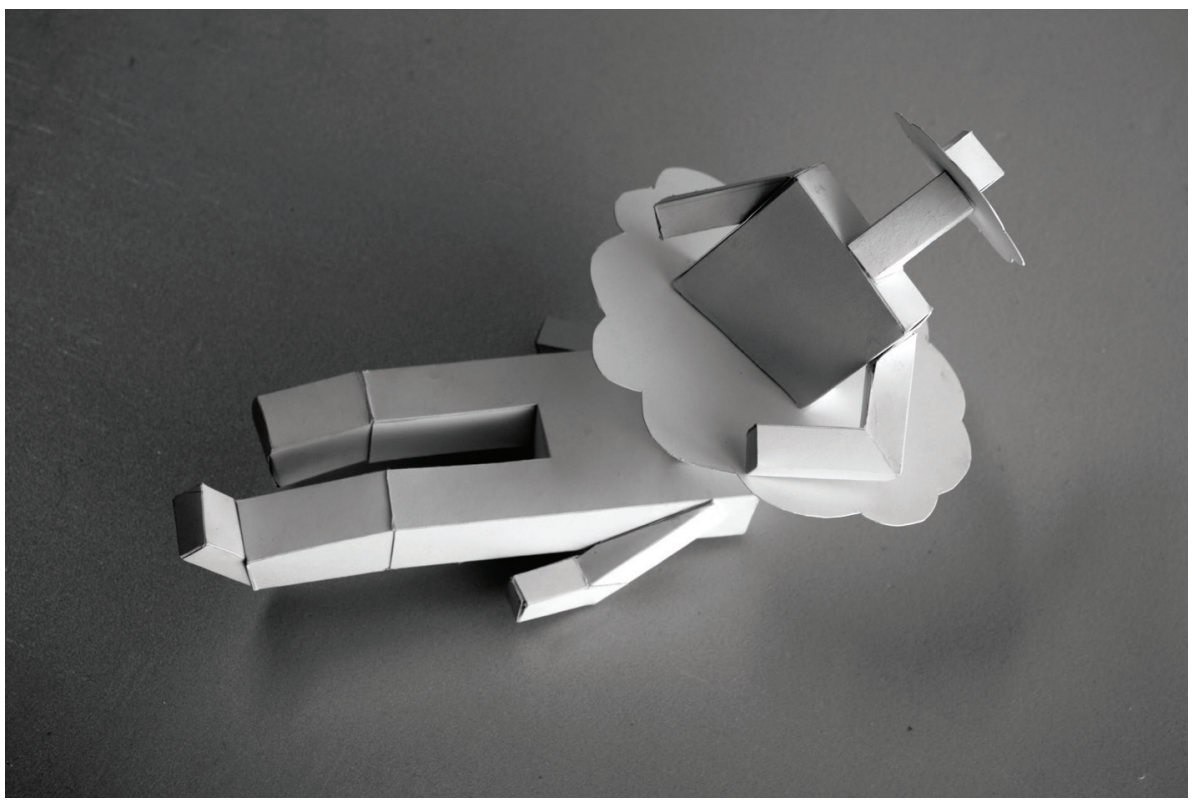

João Felix, Pedro Lopes 

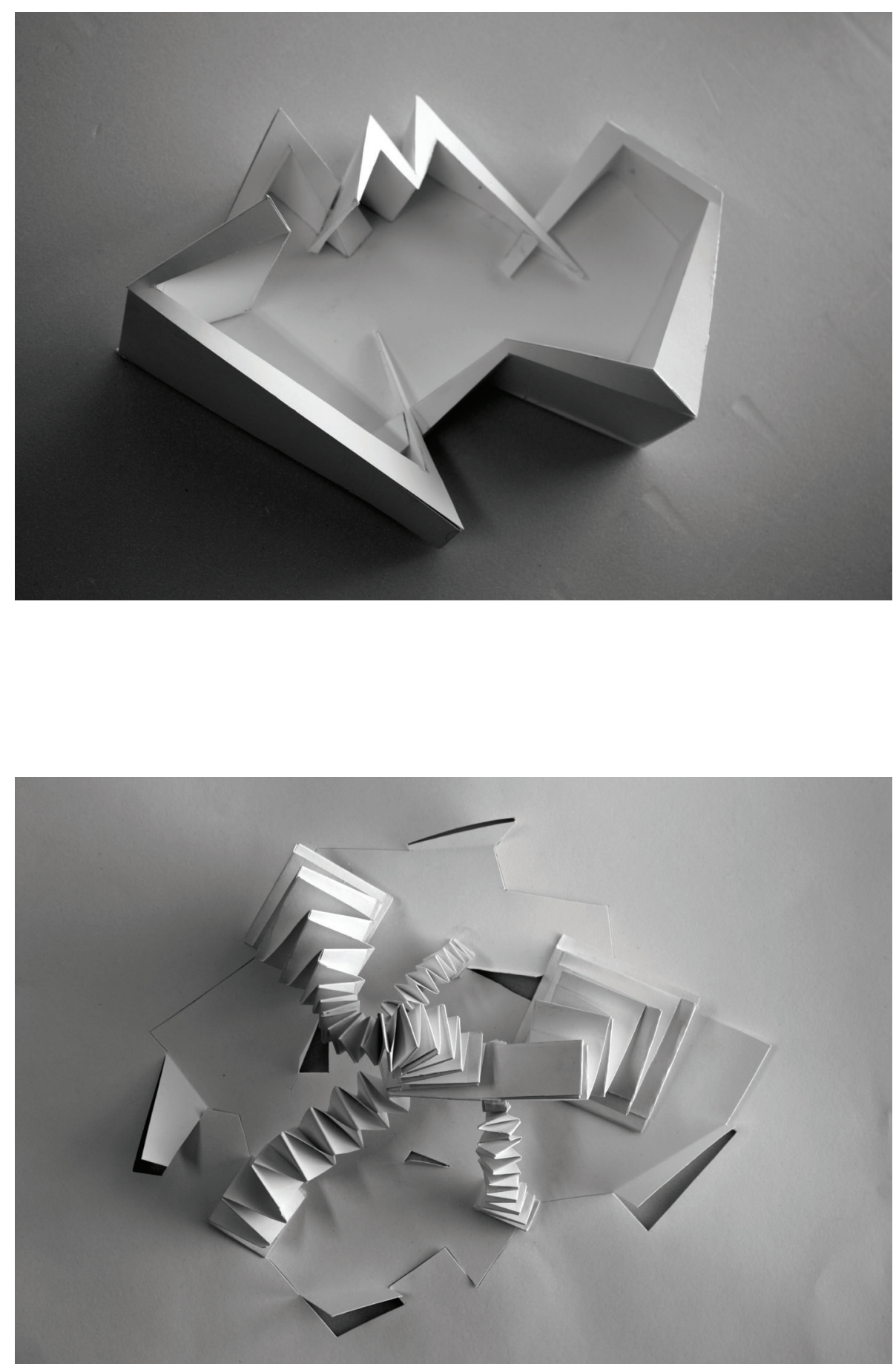

Joana Barros, Miguel Vieira 

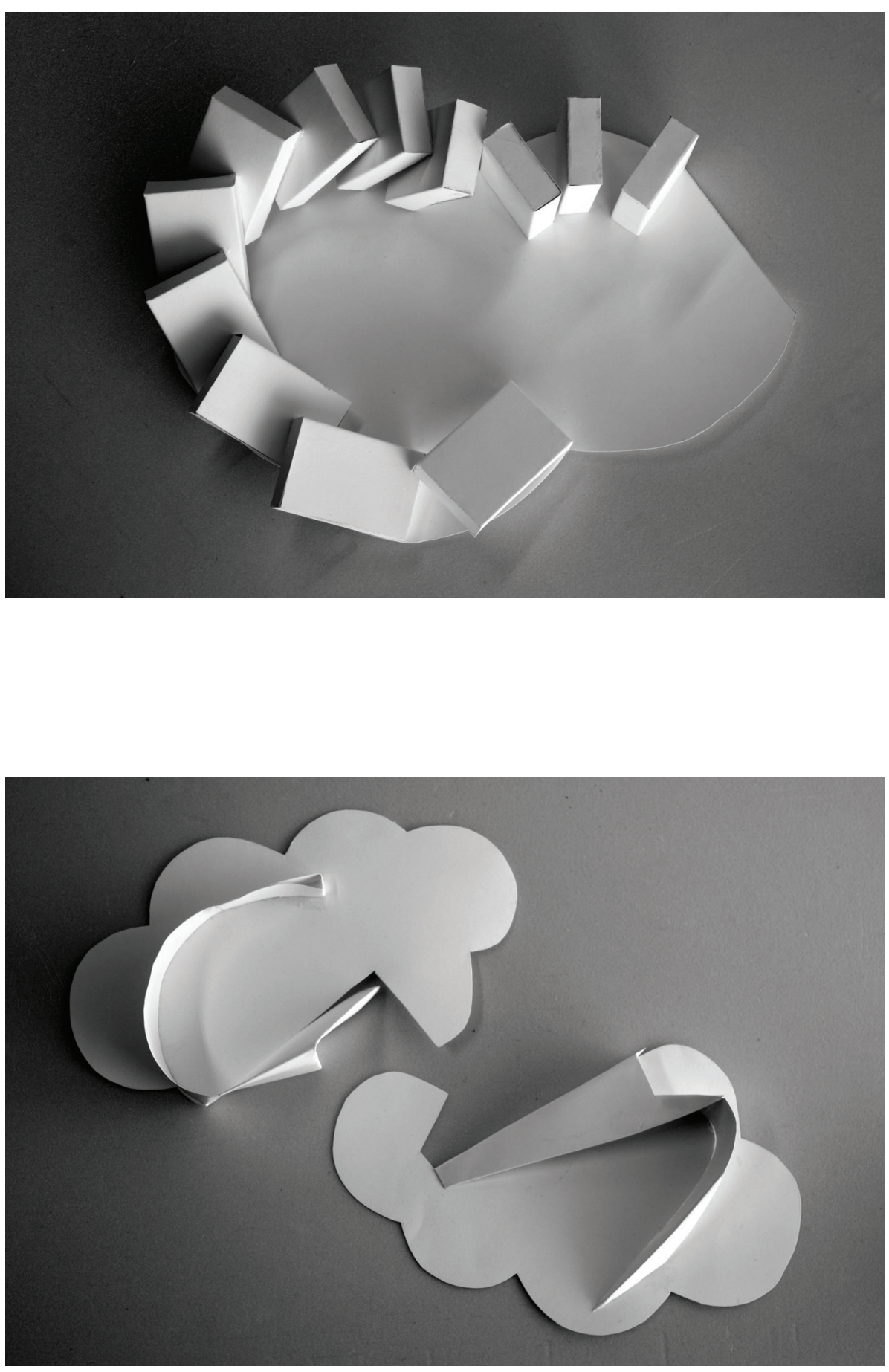

André Almeida, Ângela Rebelo 

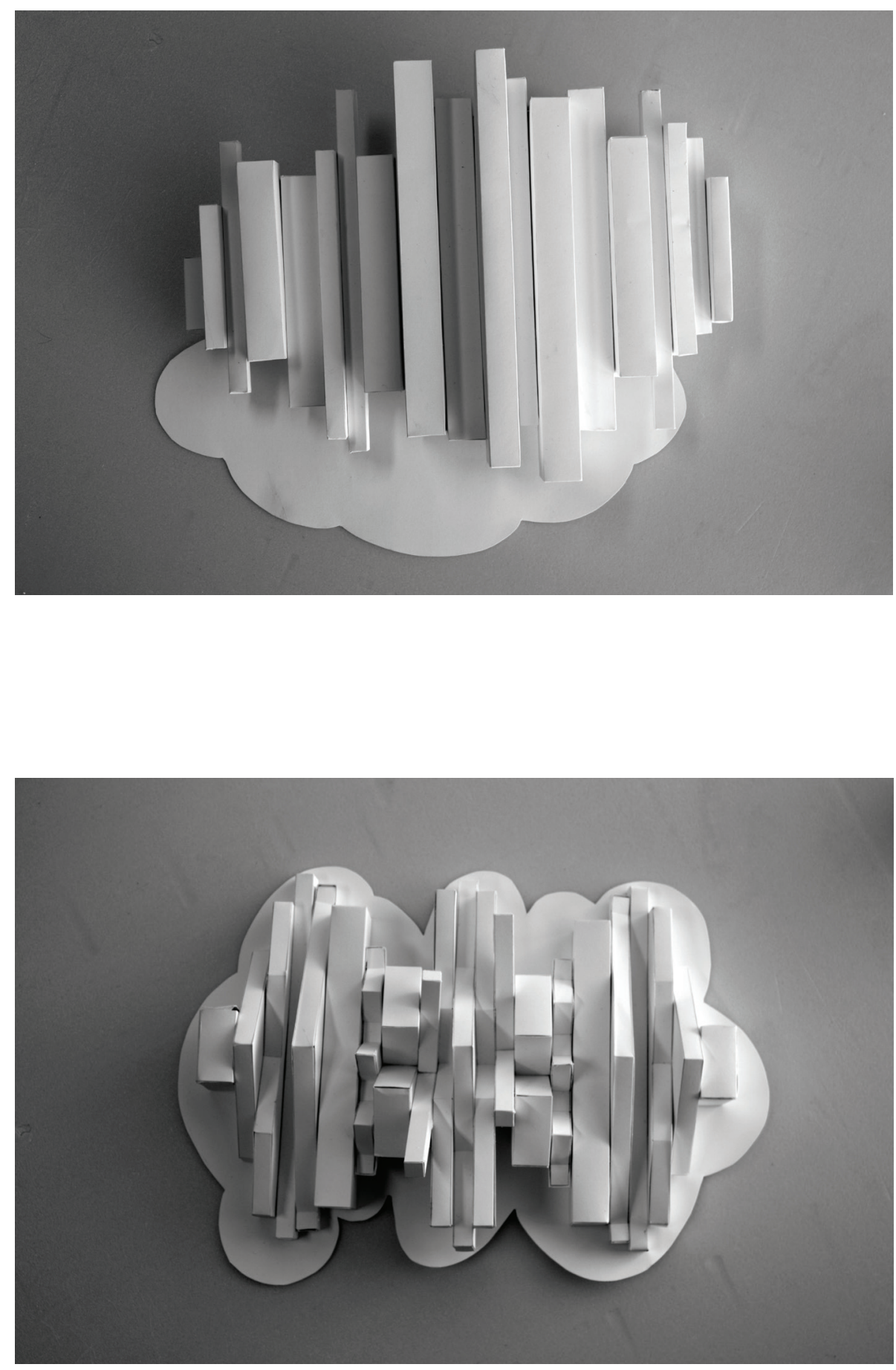

Eloísa D'Eça, Soraia Piedade 


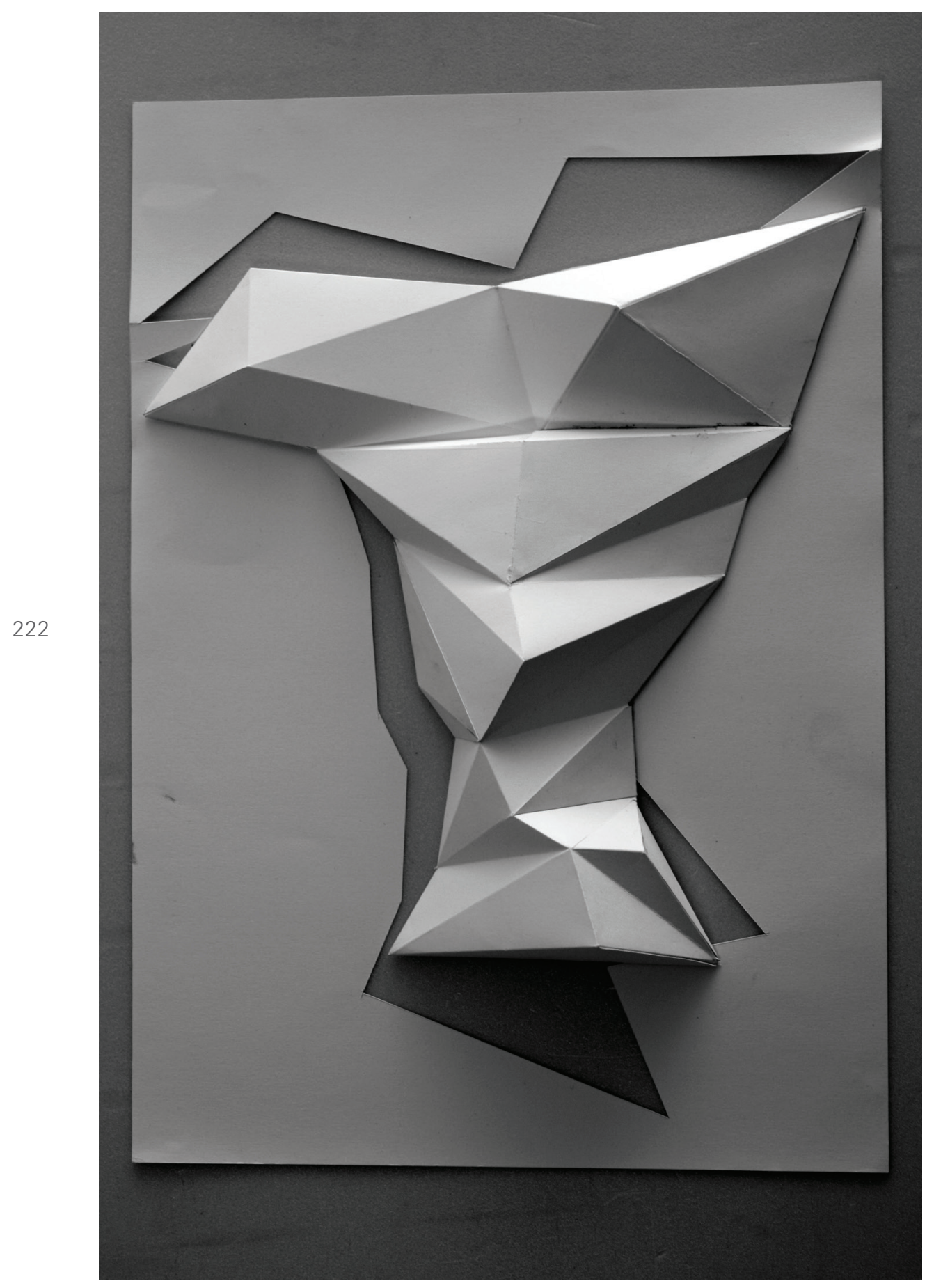

Maria Moura 

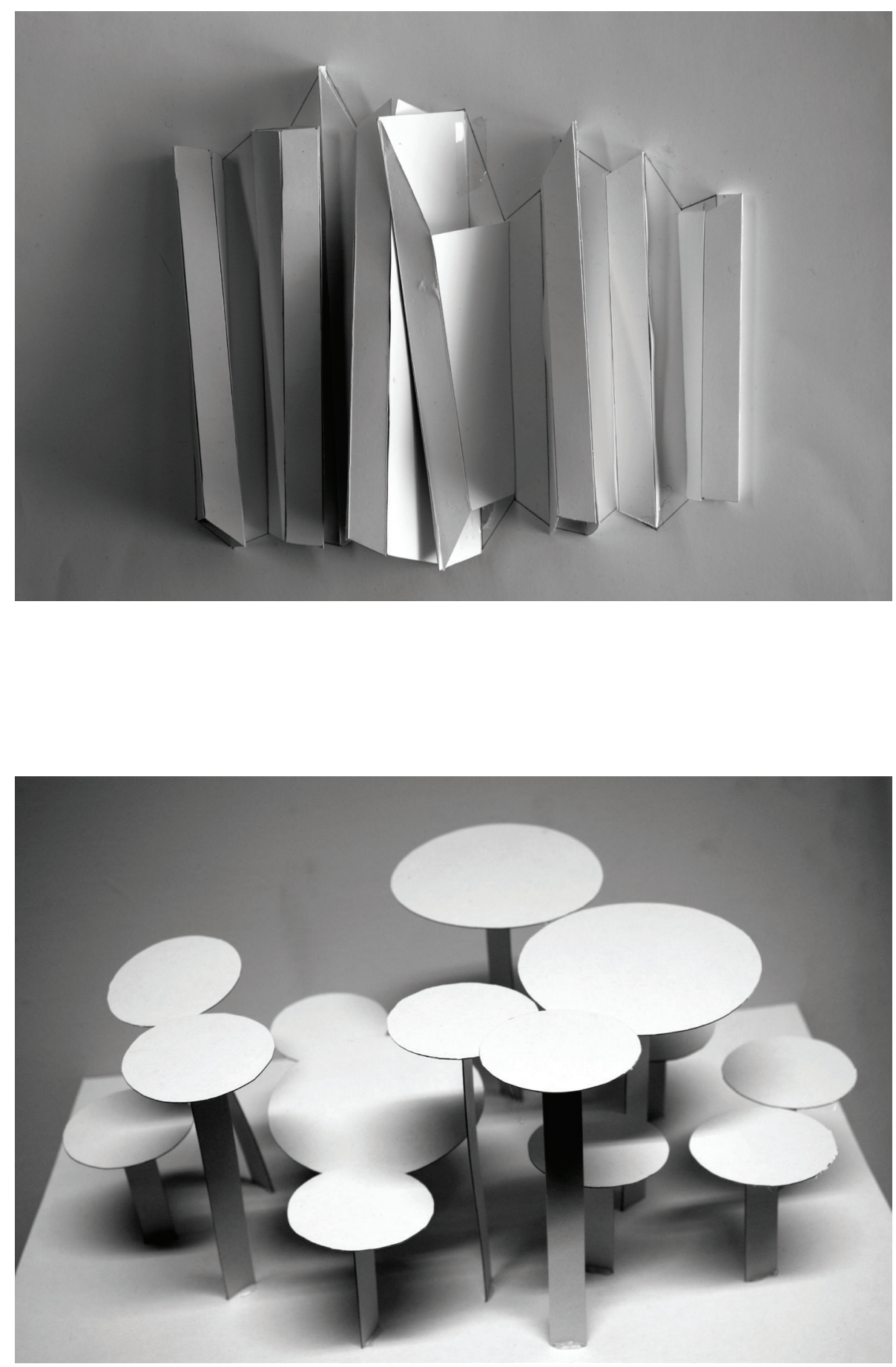

Rita Vitorino, Patrícia Coelho 

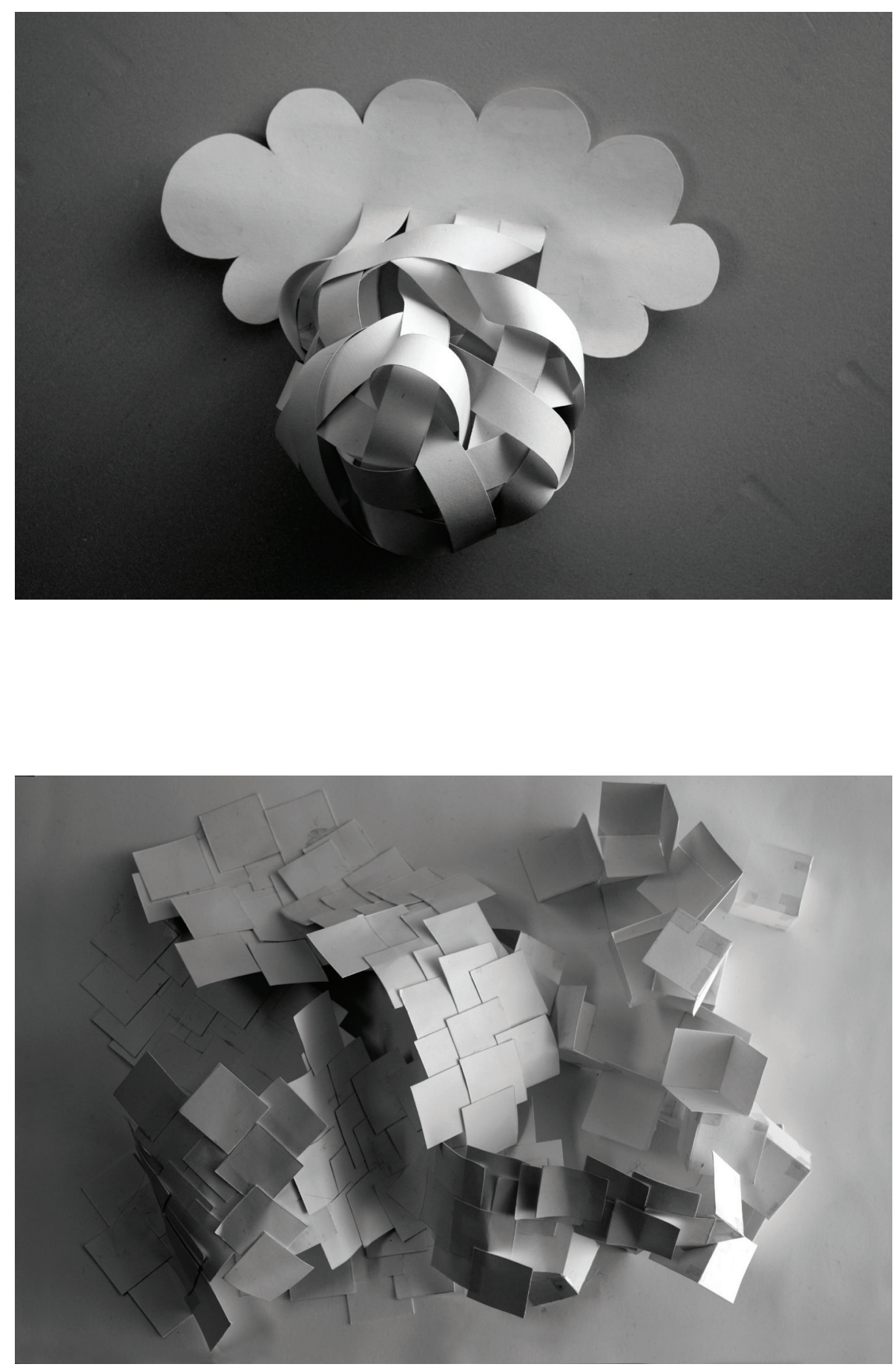

Dominika Van Eenbergen, Joana Amorim 


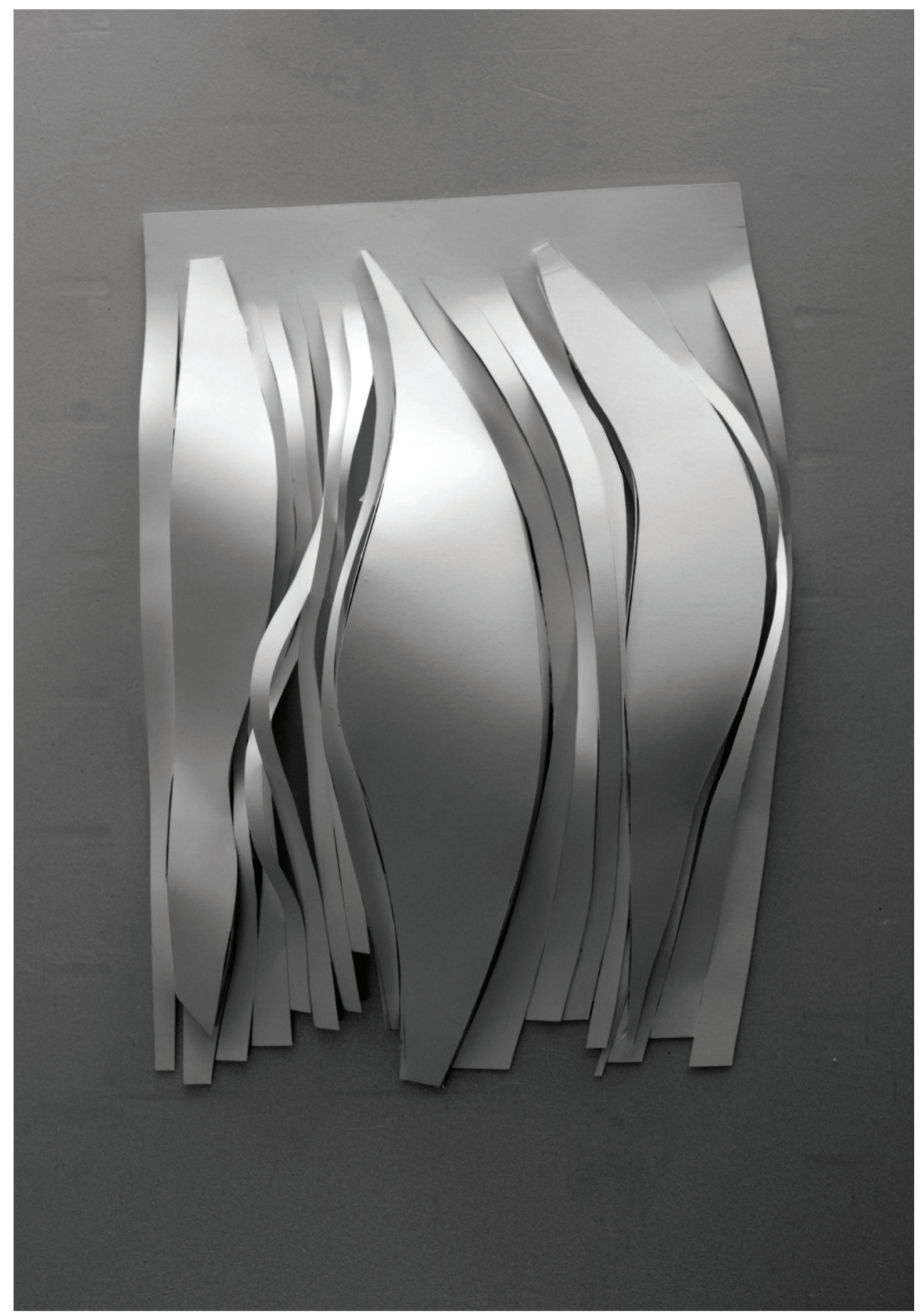

Alexandre Martins 

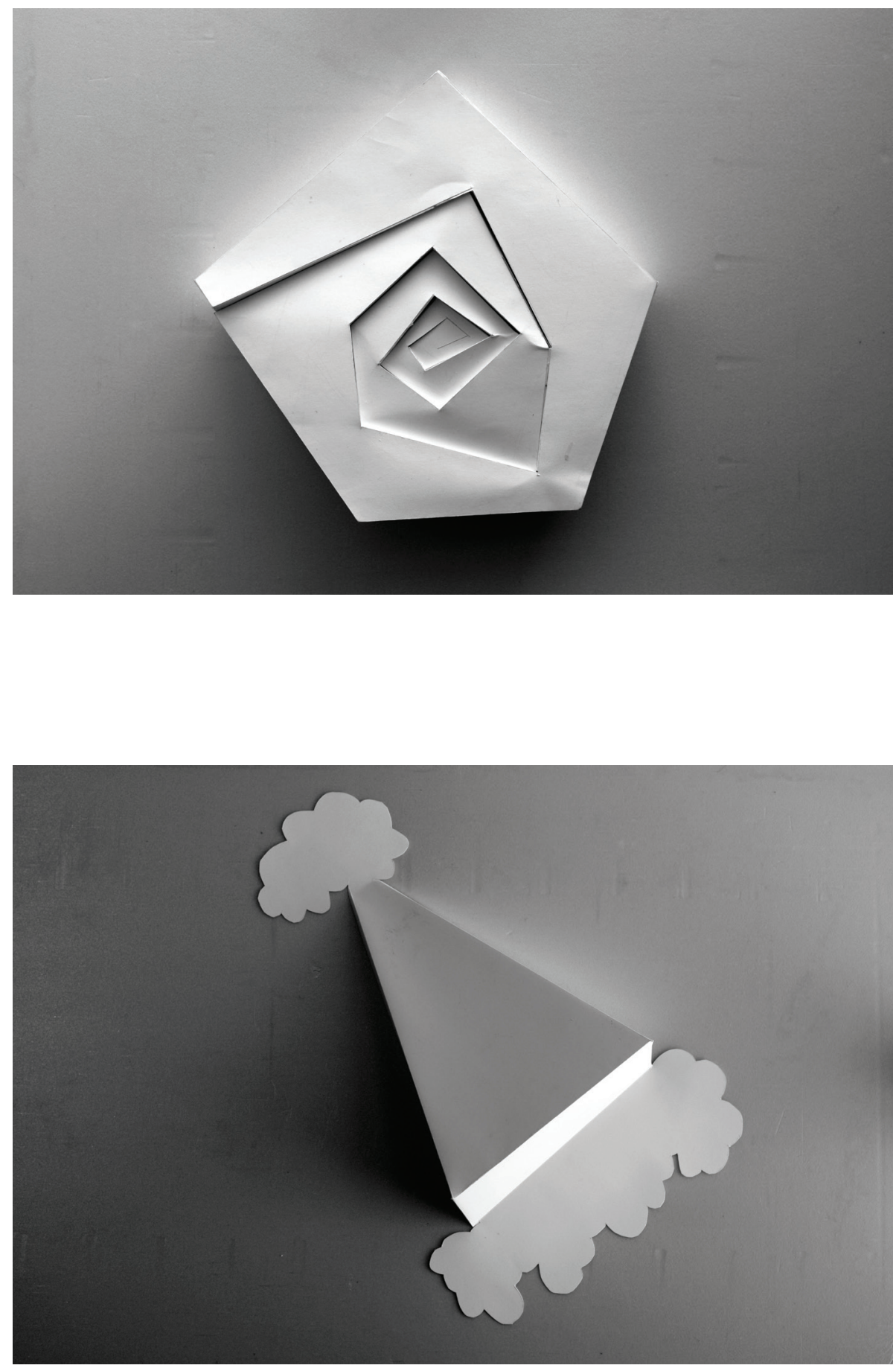

Vitor Pereira, Stephanie Paixão 


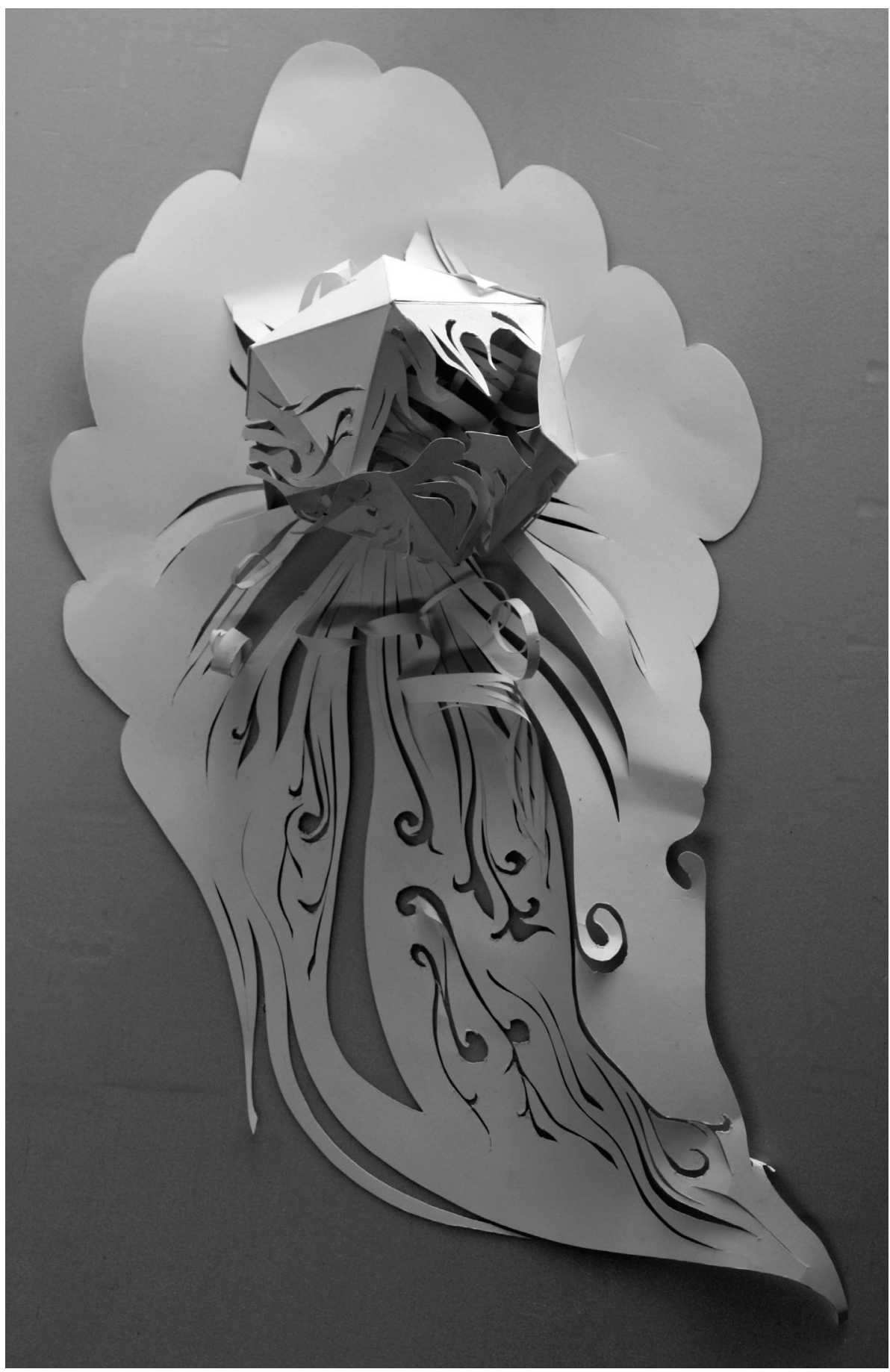



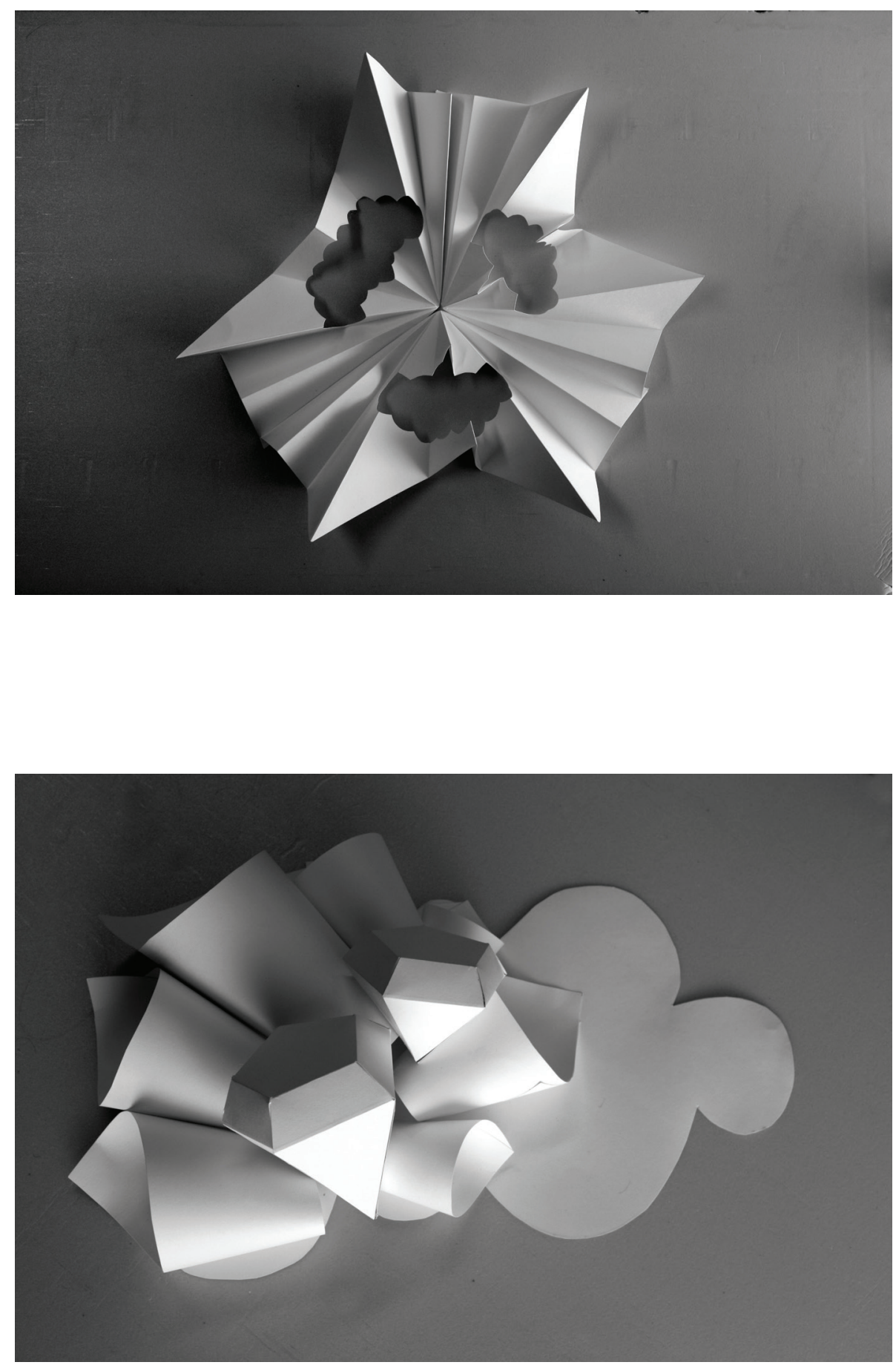

Andreia Sousa, Vanessa Marques 


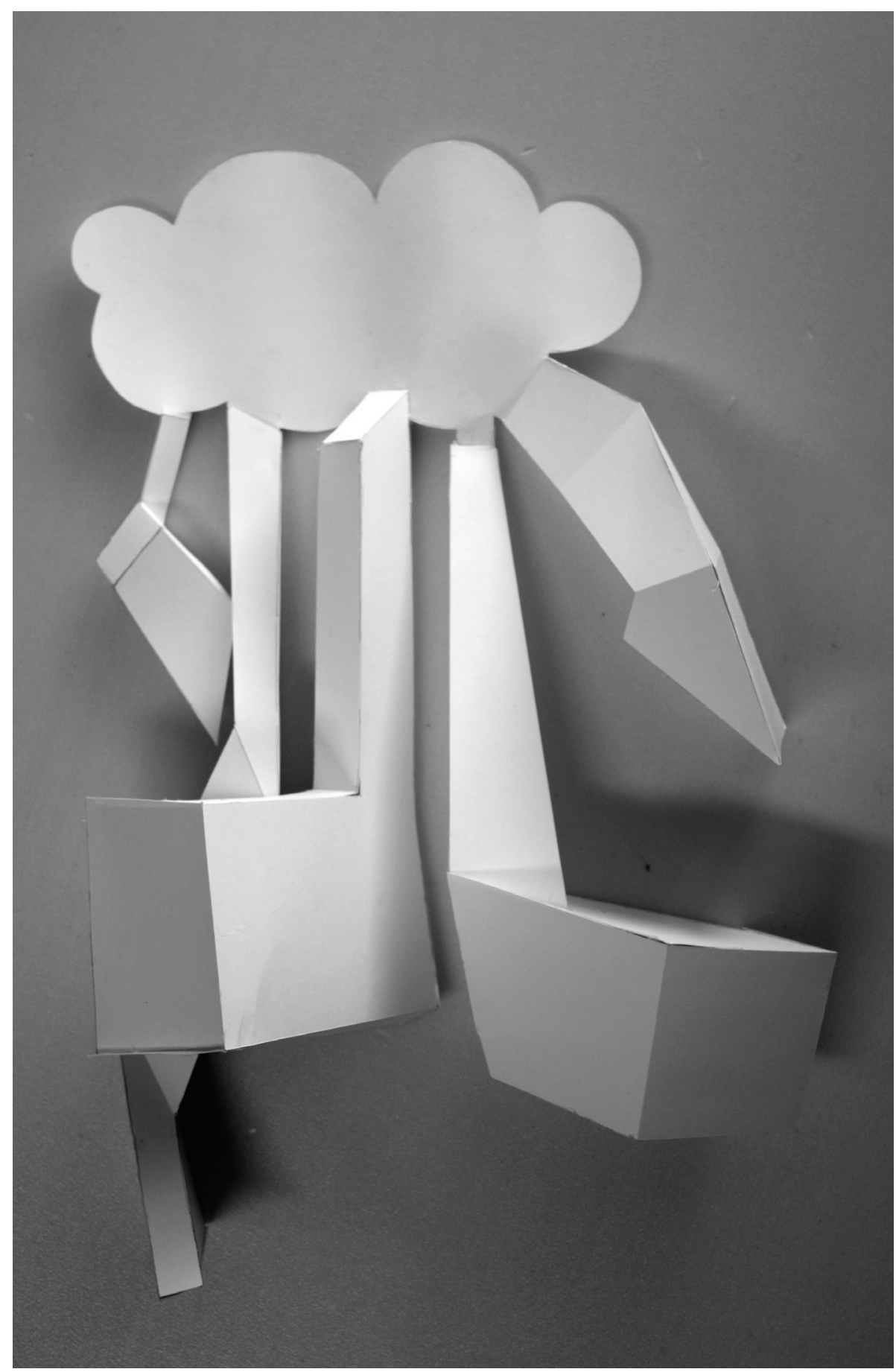



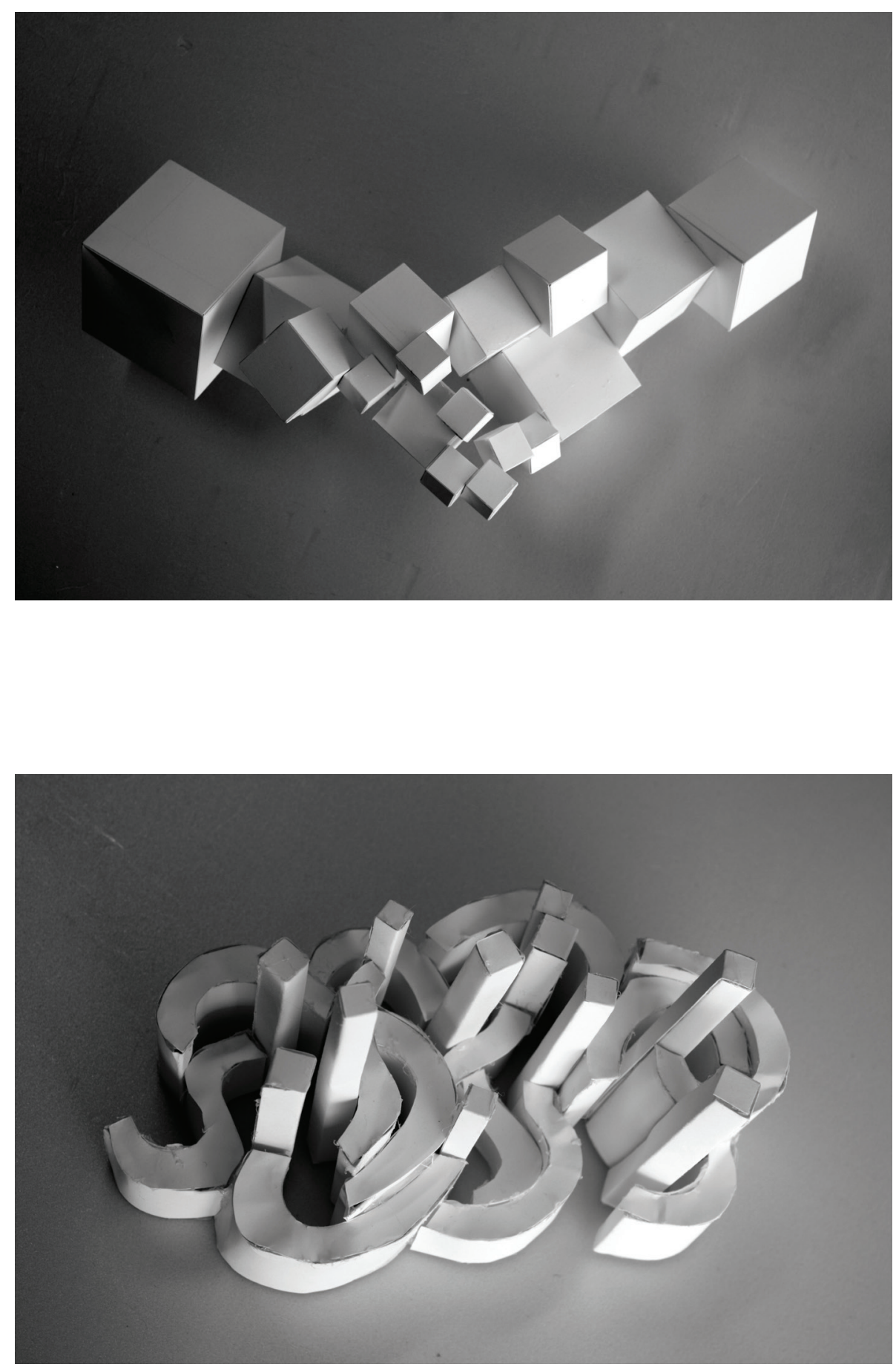

Ana Pais, Inês Pinheiro 


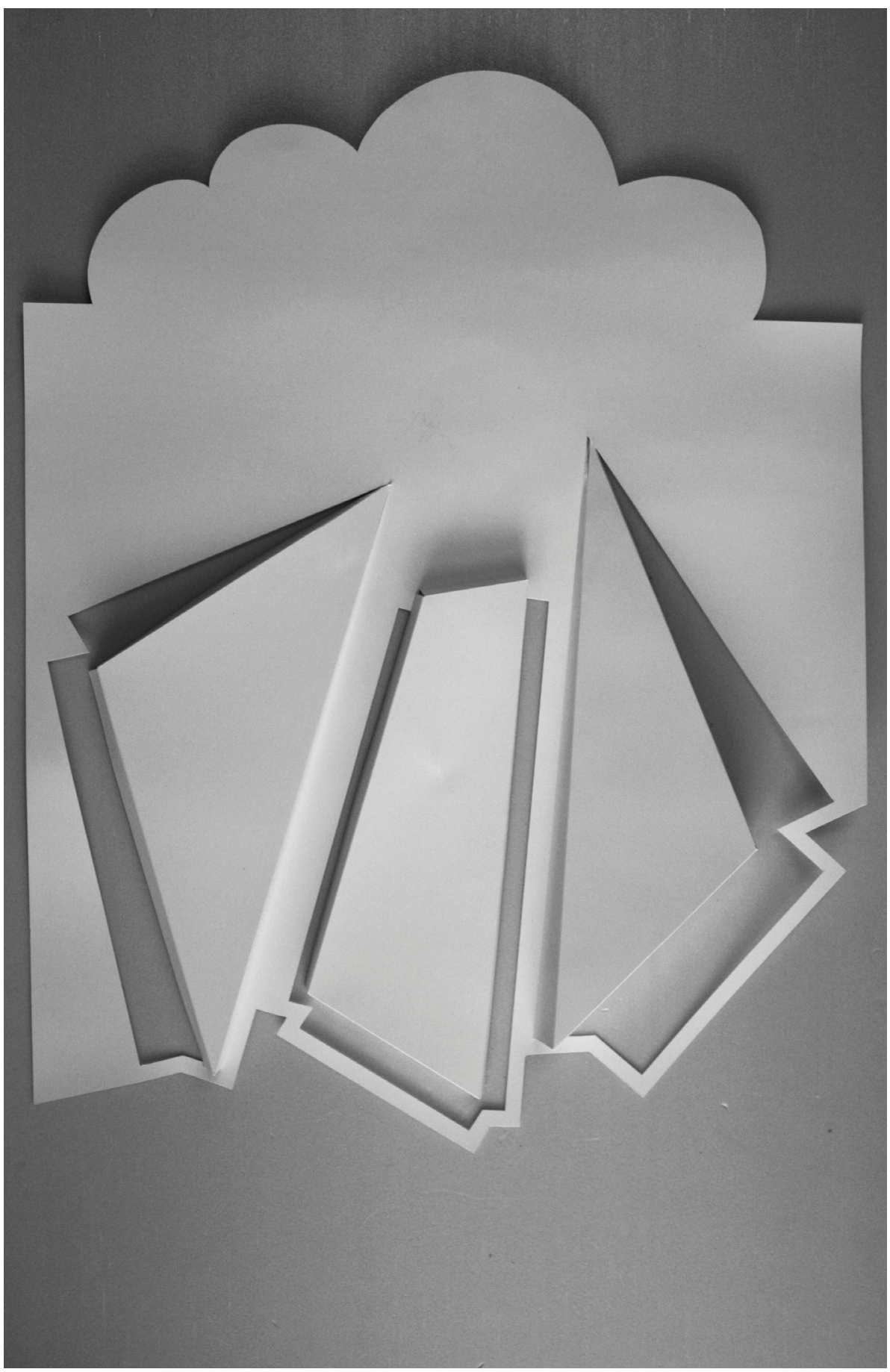

231

Alexander Fadeev 
(Página deixada propositadamente em branco) 


$$
\text { . } 919 . \frac{I}{U}
$$

